\title{
Biotic and abiotic control of microbial community structure and activity in forest soils
}

\author{
A thesis submitted to Bangor University by \\ Anna Gunina \\ In candidature for the degree \\ Philosophiae Doctor
}

August 2017

School of Environment, Natural Resources and Geography

Bangor University,

Bangor, Gwynedd,

P R I F Y S G O L

LL57 2UW, UK

(For co-evaluation at the University of Göttingen) 
"Мы все учились понемногу Чему-нибудь и как-нибудь, Так воспитаньем, слава богу, У нас немудрено блеснуть".

"We've all acquired some education A bit of this a bit of that, God be thanked, some imitation, And we can all display éclat".

(A.C. Пушкин/A.S.Pushkin) 


\section{Declaration and Consent}

\section{Details of the Work}

I hereby agree to deposit the following item in the digital repository maintained by Bangor University and/or in any other repository authorized for use by Bangor University.

\section{Author Name:}

Title:

\section{Supervisor/Department:}

\section{Funding body (if any):}

Qualification/Degree obtained:

This item is a product of my own research endeavours and is covered by the agreement below in which the item is referred to as "the Work". It is identical in content to that deposited in the Library, subject to point 4 below.

\section{Non-exclusive Rights}

Rights granted to the digital repository through this agreement are entirely non-exclusive. I am free to publish the Work in its present version or future versions elsewhere.

I agree that Bangor University may electronically store, copy or translate the Work to any approved medium or format for the purpose of future preservation and accessibility. Bangor University is not under any obligation to reproduce or display the Work in the same formats or resolutions in which it was originally deposited.

\section{Bangor University Digital Repository}

I understand that work deposited in the digital repository will be accessible to a wide variety of people and institutions, including automated agents and search engines via the World Wide Web.

I understand that once the Work is deposited, the item and its metadata may be incorporated into public access catalogues or services, national databases of electronic theses and dissertations such as the British Library's EThOS or any service provided by the National Library of Wales.

I understand that the Work may be made available via the National Library of Wales Online Electronic Theses Service under the declared terms and conditions of use (http://www.llgc.org.uk/index.php?id=4676). I agree that as part of this service the National Library of Wales may electronically store, copy or convert the Work to any approved medium or format for the purpose of future preservation and accessibility. The National Library of Wales is not under any 
obligation to reproduce or display the Work in the same formats or resolutions in which it was originally deposited.

\section{Statement 1:}

This work has not previously been accepted in substance for any degree and is not being concurrently submitted in candidature for any degree unless as agreed by the University for approved dual awards.

Signed (candidate)

Date

\section{Statement 2:}

This thesis is the result of my own investigations, except where otherwise stated. Where correction services have been used, the extent and nature of the correction is clearly marked in a footnote(s).

All other sources are acknowledged by footnotes and/or a bibliography.

Signed (candidate)

Date

\section{Statement 3:}

I hereby give consent for my thesis, if accepted, to be available for photocopying, for inter-library loan and for electronic storage (subject to any constraints as defined in statement 4), and for the title and summary to be made available to outside organisations.

Signed (candidate)

Date

NB: Candidates on whose behalf a bar on access has been approved by the Academic Registry should use the following version of Statement 3: 


\section{Statement 3 (bar):}

I hereby give consent for my thesis, if accepted, to be available for photocopying, for inter-library loans and for electronic storage (subject to any constraints as defined in statement 4), after expiry of a bar on access.

Signed (candidate)

Date

\section{Statement 4:}

Choose one of the following options

a) I agree to deposit an electronic copy of my thesis (the Work) in the Bangor University (BU) Institutional Digital Repository, the British Library ETHOS system, and/or in any other repository authorized for use by Bangor University and where necessary have gained the required permissions for the use of third party material.

b) I agree to deposit an electronic copy of my thesis (the Work) in the Bangor University (BU) Institutional Digital Repository, the British Library ETHOS system, and/or in any other repository authorized for use by Bangor University when the approved bar on access has been lifted.

c) I agree to submit my thesis (the Work) electronically via Bangor University's e-submission system, however I opt-out of the electronic deposit to the Bangor University (BU) Institutional Digital Repository, the British Library ETHOS system, and/or in any other repository authorized for use by Bangor University, due to lack of permissions for use of third party material.

Options B should only be used if a bar on access has been approved by the University.

\section{In addition to the above I also agree to the following:}

1. That I am the author or have the authority of the author(s) to make this agreement and do hereby give Bangor University the right to make available the Work in the way described above.

2. That the electronic copy of the Work deposited in the digital repository and covered by this agreement, is identical in content to the paper copy of the Work deposited in the Bangor University Library, subject to point 4 below. 
3. That I have exercised reasonable care to ensure that the Work is original and, to the best of my knowledge, does not breach any laws - including those relating to defamation, libel and copyright.

4. That I have, in instances where the intellectual property of other authors or copyright holders is included in the Work, and where appropriate, gained explicit permission for the inclusion of that material in the Work, and in the electronic form of the Work as accessed through the open access digital repository, or that I have identified and removed that material for which adequate and appropriate permission has not been obtained and which will be inaccessible via the digital repository.

5. That Bangor University does not hold any obligation to take legal action on behalf of the Depositor, or other rights holders, in the event of a breach of intellectual property rights, or any other right, in the material deposited.

6. That I will indemnify and keep indemnified Bangor University and the National Library of Wales from and against any loss, liability, claim or damage, including without limitation any related legal fees and court costs (on a full indemnity bases), related to any breach by myself of any term of this agreement.

Signature: Date : 


\section{Table of contents}

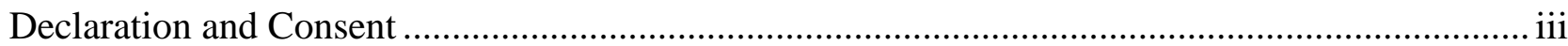

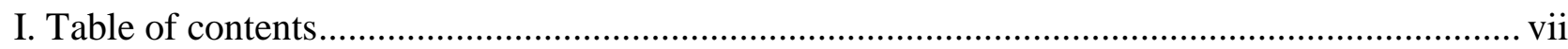

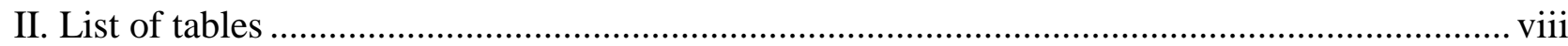

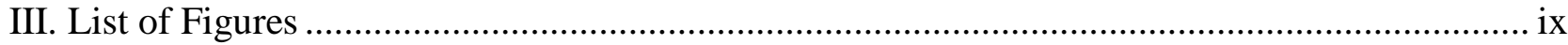

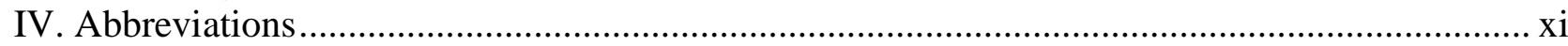

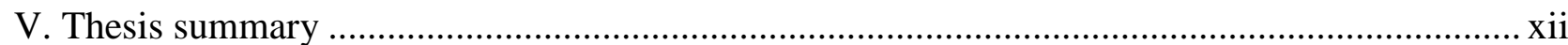

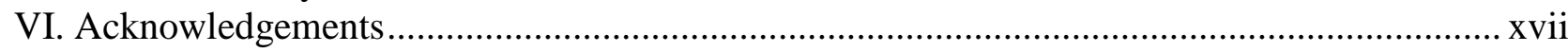

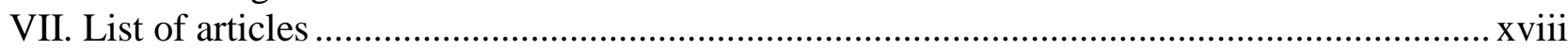

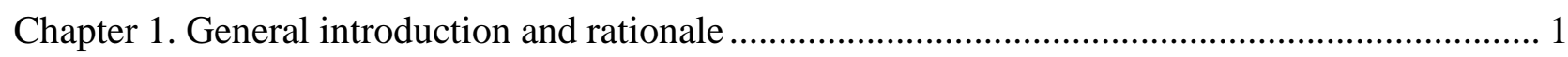

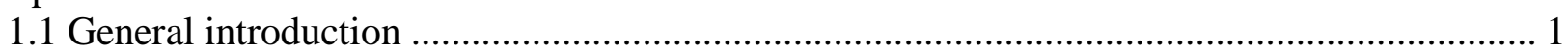

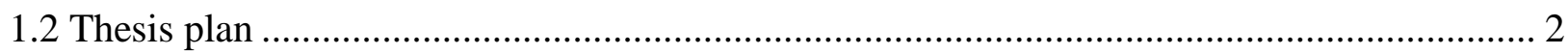

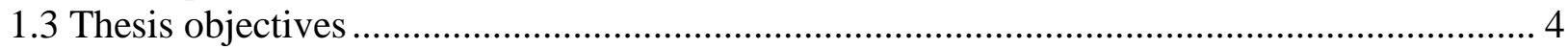

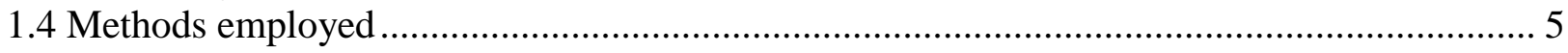

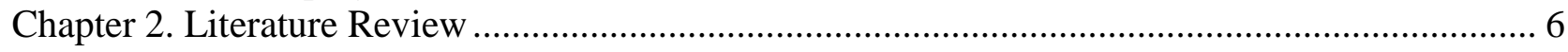

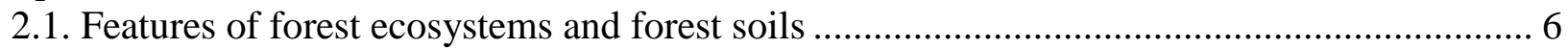

2.1.1 Differences between forest and agricultural soils ........................................................ 6

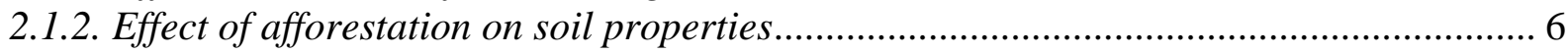

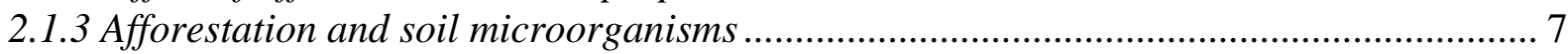

2.2. Microbial community composition in forest soils .......................................................... 8

2.2.1. Effect of forest type on the structure of soil microbial communities .............................. 8

2.2.2 Effect of abiotic factors on the structure of soil microbial communities ......................... 8

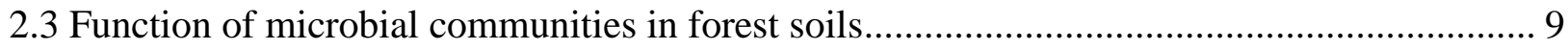

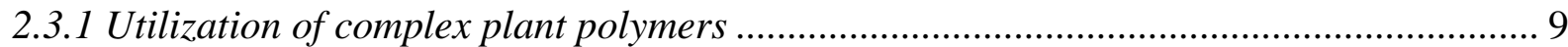

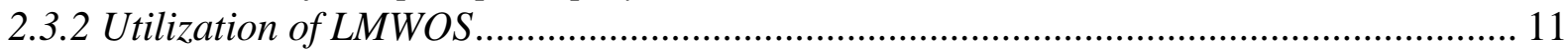

Chapter 3 Article I Determining the optimal temperature and precipitation for microbial community development in montane forest ecosystems: PLFA analysis along a $3500 \mathrm{~m}$ altitudinal

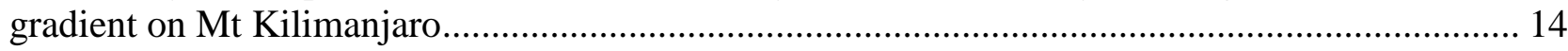
Chapter 4 Article II Response of soil microbial community to afforestation with pure and mixed

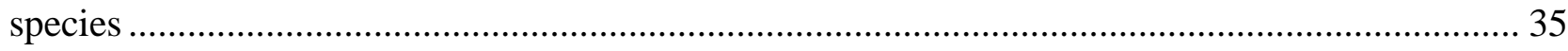

Chapter 5 Article III Effects of afforestation on enzyme activities in soil .................................. 57

Chapter 6 Article IV Microbial nitrogen cycling gene abundance does not reflect nitrogen

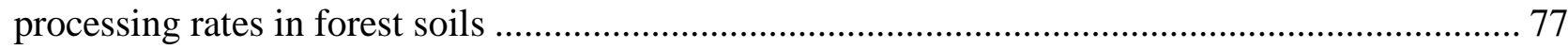

Chapter 7 Article V Sugars in soil and sweets for microorganisms: Review of origin, content,

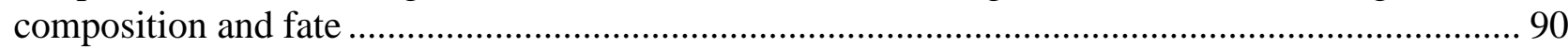

Chapter 8 Article VI Microbial uptake and utilization of low molecular weight organic substrates

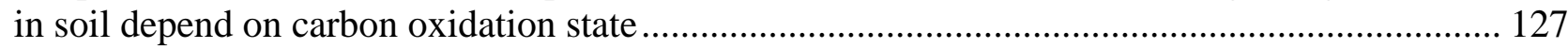

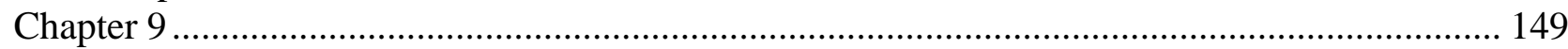

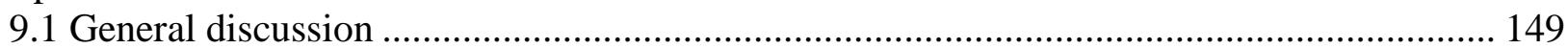

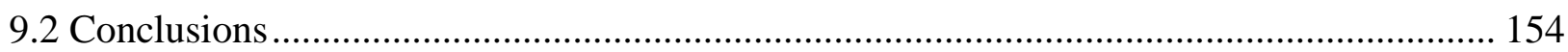

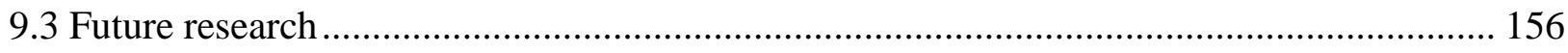

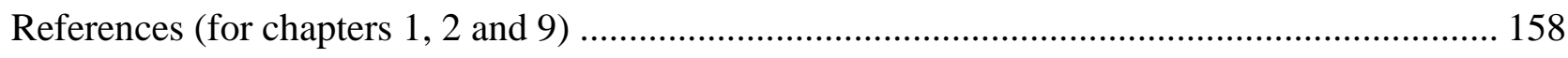

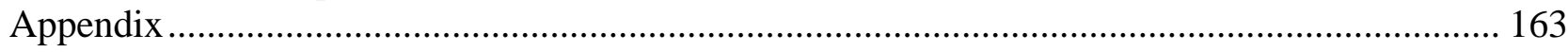




\section{List of tables}

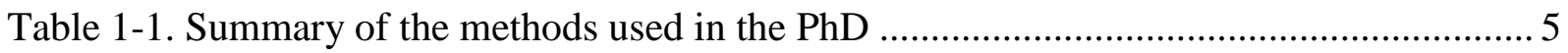

Table 2-1. Enzyme activities determined in soil science research....................................... 10

Table 3-1. Soil properties of the 3500 m elevation gradient on the Mt. Kilimanjaro............... 23

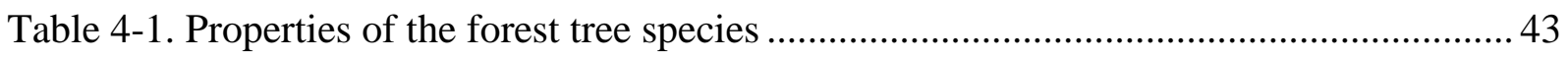

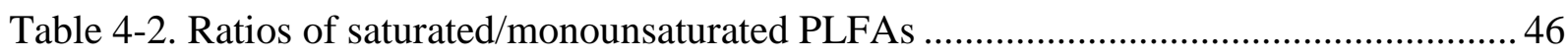

Table 5-1. Soil biological and chemical properties after afforestation and in the control plot. 61

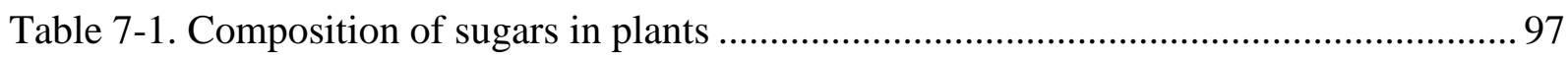

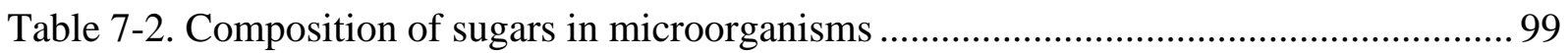

Table 7-3. Carbohydrate groups extracted from soil by various solutions. ............................ 102

Table 7-4. Estimated glucose-C input from plants on the example of deciduous forest ........ 116

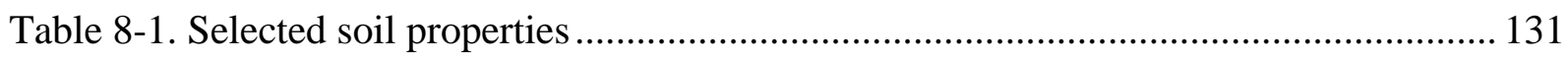

Table 8-2. Single first order kinetic coefficients describing the depletion of individual carbon

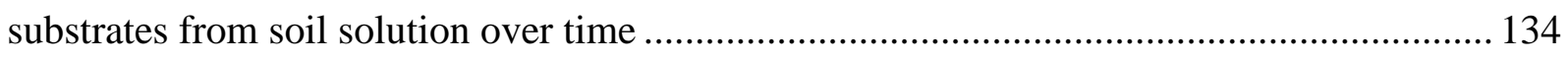

Table 8-3. Double first order kinetic coefficients describing the depletion of individual carbon

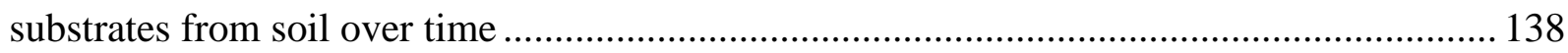




\section{List of figures}

Figure 1-1. Schematic overview of experimental chapters of the $\mathrm{PhD}$

Figure 3-1. Changes of climatic variables - mean annual temperature (MAT) and mean annual precipitation (MAP), and total PLFAs content within $3500 \mathrm{~m}$ elevation gradient on the Mt.

Kilimanjaro. 21

Figure 3-2. Changes of microbial biomarkers portions calculated based on PLFAs analysis (in mol \%) along a $3500 \mathrm{~m}$ elevation gradient at Mt. Kilimanjaro

Figure 3-3. Changes of the Gram-positive to Gram-negative (G+/G-) and fungi to bacteria (F/B) ratios along a $3500 \mathrm{~m}$ elevation gradient at Mt. Kilimanjaro (top). Relationship between $\mathrm{pH}$ values and fungi to bacteria ratio (bottom)....

Figure 3-4. Score plot of PCA presenting the separation of forests along the principal component PC1 and PC2 (top) and loading values for the PLFAs (bottom) for the $3500 \mathrm{~m}$ elevation gradient for Mt. Kilimanjaro.

Figure 3-5. Type II scaled Redundancy Analysis (top) of the relation between PLFAs and environmental factors at six Mt. Kilimanjaro ecosystems. Partial Redundancy Analysis (bottom) shows single and combined contribution of climatic and environmental variables for explaining the model variance.

Figure 3-6. Summary of published total PLFAs content in forest soils along mountain elevation gradients in mountain ecosystems of various climatic zones.

Figure 4-1. Changes of soil chemical properties in the various forest treatments relative to the agricultural soil.

Figure 4-2. Content of total PLFAs (nmol g${ }^{-1}$ soil) in the different forest treatments and the agricultural soil.

Figure 4-3. Changes in the content (nmol g ${ }^{-1}$ soil) of specific microbial indicators PLFAs in the

different forest treatments relative to the agricultural soils, presented as portion of changes........ 45

Figure 4-4. Score plot of PCA presenting the separation of mono- and mixture species forests along the principal component PC1 and PC2 (top) and loading values for the PLFAs (bottom)... 47 Figure 5-1. Dependence of enzyme activities from substrate concentrations in soil under pure and mix species forests.

Figure 5-2. $V_{\max }$ parameter of kinetic of the enzymes responsible for $C$ ( $\beta$-glucosidase and xylanase), $\mathrm{N}$ (Leucyl aminopeptidases and $\mathrm{N}$-acetyl glucosaminidase) and $\mathrm{P}$ (acids-phosphatase)

cycles for the soils formed under mono-, two- and three species mixtures forests.

Figure 5-3. Dependence of $\mathrm{V}_{\max }$ values of $\beta$-glucosidase (BG) and leucine-aminopeptidase (LAP)

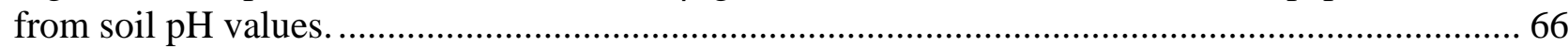

Figure 5-4. Data for the expected values of $\mathrm{V}_{\max }$ for the two and three species mixtures.............. 67 Figure $5-5 . \mathrm{K}_{\mathrm{m}}$ and $\mathrm{V}_{\max }$ parameters of the enzymes responsible for $\mathrm{C}$ ( $\beta$-glucosidase and xylanase), $\mathrm{N}$ (Leucyl aminopeptidases and $\mathrm{N}$-acetyl glucosaminidase) and $\mathrm{P}$ (acids-phosphatase) cycles for the soils formed under mono-, two- and three species mixtures forests.

Figure 6-1. Total abundance of ammonia-oxidizing archaea and bacteria amoA AOA and AOB, denitrifying bacteria nirS and nirK and fungal ITS, bacterial $16 \mathrm{~S}$, presented as $\log _{10}$ gene copies

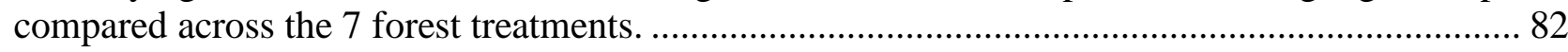

Figure 6-2. Nitrogen cycling process rates among the seven forest treatments........................... 83 Figure 6-3. Principal Components Analysis of all gene copies, N process rates, and soil chemistry data as dependent variables, grouped among the 7 forest treatments as the explanatory variables (a), with gene copies and soil chemistry data only (b), and with only gene copies grouped by the

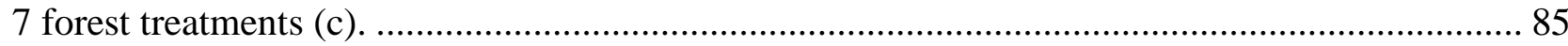


Figure 7-1. Average content of cellulose (Cel) and hemicellulose (Hem) in green leafs, litters and roots of main plant groups (\% of dry weight).

Figure 7-2. Total sugar C content depending on: SOM (top), soil texture (bottom left), plant

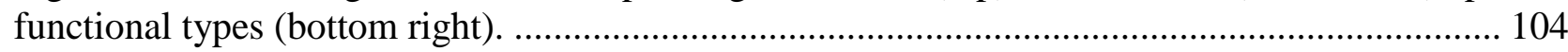

Figure 7-3. Cellulose and non-cellulose hexoses and pentoses depending on SOM content....... 105 Figure 7-4. Content of total and non-cellulose hexoses and pentoses in soils (top) and in hot and cold water extracts (bottom). 106 Figure 7-5. The ratios of galactose+mannose/arabinose+xylose (GM/AX) in microbial and plant polyssacharides and in non-cellulose sugars in soils developed under coniferous and deciduous trees, crops and grasses. 108 Figure 7-6. Fate of sugars in soil. Primary (plant derived) and secondary (microbially derived) inputs of sugars are presented.

Figure 7-7. Rates of glucose mineralization in soil. 112 Figure 7-8. Dynamics and partitioning of glucose-C for three pools: living microbial biomass, dead microbial residues and SOM.

Figure 8-1. Temporal dynamics of ${ }^{14} \mathrm{C}$-labelled sugar, organic acid and amino acid disappearance from soil solution.

Figure 8-2. Relationship between the half-life (min) of different LMWOS in soil solution and their $\mathrm{C}$ oxidation state (top panel) and number of $\mathrm{C}$ atoms in the molecule (bottom panel)........ 136 Figure 8-3. Cumulative ${ }^{14} \mathrm{C}-\mathrm{CO}_{2}$ production from mineralization of ${ }^{14} \mathrm{C}$-labelled substances in soil.

Figure 8-4. Relationship between ${ }^{14} \mathrm{C}$ remaining in the cytosol, $\mathrm{SOC}$ and $\mathrm{CO}_{2}$ pools and $\mathrm{C}$ oxidation state (top panel) and ${ }^{14} \mathrm{C}$ remaining in the cytosol and number of $\mathrm{C}$ atoms and $-\mathrm{COOH}$ groups (bottom panel) in different LMWOS.

Figure 8-5. Relationship between ${ }^{14} \mathrm{C}$ incorporated into cytosol (anabolism) $/{ }^{14} \mathrm{C}$ incorporated into $\mathrm{CO}_{2}$ (catabolism) and $\mathrm{C}$ oxidation state at the end of LMWOS mineralization experiment. 140 Figure 8-6. Schematic representation showing the dependence of microbial uptake rate (red), utilization (green) and mineralization efficiency (black) of three distinct classes of LMWOS as a function of substrate $\mathrm{C}$ oxidation state. 


\section{Abbreviations}

$\begin{array}{ll}\text { SOM } & \text { Soil Organic Matter } \\ \text { SOC } & \text { Soil Organic Carbon } \\ \text { SON } & \text { Soil Organic Nitrogen } \\ \text { DOC } & \text { Dissolved Organic Carbon } \\ \text { LMWOS } & \text { Low Molecular Weight Organic Substances } \\ \text { POM } & \text { Particulate Organic Matter } \\ \text { MAP } & \text { Mean Annual Precipitation } \\ \text { MAT } & \text { Mean Annual Temperature } \\ \text { MB } & \text { Microbial Biomass } \\ \text { PLFAs } & \text { Phospholipid Fatty Acids } \\ \text { G- } & \text { Gram-negative biomarkers } \\ \text { G+ } & \text { Gram-positive biomarkers } \\ \text { AMF } & \text { Arbuscular Mycorrhizal Fungi }\end{array}$




\section{Thesis summary}

Microorganisms are the key drivers of most processes in soil. Therefore, factors regulating microbial composition, functions and activities are hot topics in soil science. Focusing on forest ecosystems, this $\mathrm{PhD}$ aimed to evaluate: i) abiotic (temperature and precipitation) and biotic (trees species identity) factors regulating the composition of microbial communities in forest soils, ii) the effects of forest biodiversity on microbial decomposition of organic polymeric compounds of plant litter and iii) the effects of intrinsic properties of common low molecular weight organic substances (LMWOS) on their microbial uptake and subsequent metabolization by soil microorganisms.

It was found that abiotic factors affect soil microbial community structure in forests indirectly, mainly via modification of environmental conditions (soil $\mathrm{pH}$, carbon (C) and nitrogen (N) contents) and plant productivity, which was studied for the old deciduous ecosystems along a climosequence gradient of Mt. Kilimanjaro. Effects of biotic factors on microbial communities was checked for the young (10-year-old) monoculture forest in comparison with forests from mixed species with contrasting functional traits (i.e. early primary (birch and alder) vs. late successional species (beech and oak), and N-fixing (alder) vs. non-N- fixing (birch, beech and oak)) to reveal direct impact of litter quality changes, before strong modification of edaphic factors occurs. Afforestation had stronger effects on the development of fungal (increased by $50-200 \%$ based on the biomarker analysis) than of bacterial communities (increased by 20-120\%). These effects were proved for all forests, but were more pronounced under the monocultures compared to mixtures. Consequently, species identity has stronger effects than diversity on the formation of microbial community structure in soil.

Enzyme systems, responsible for decomposition of plant litter, reacted differently to afforestation with species having contrasting functional traits, even for the enzymes responsible for one element $(\mathrm{C}$ or $\mathrm{N})$. The maximum activities of $\beta$-N-acetylglucosaminidase, $\beta$-xylosidase and acid phosphatase were found for the sites, where early primary species (birch) developed simultaneously with late successional species (beech and oak), showing synergistic effects. In contrast, development of beech in monoculture strongly suppressed enzyme activities. The effects of forest biodiversity on element dynamics in soil were proven by $\mathrm{N}$ functional genes abundance and $\mathrm{N}$ cycling rates (gross and net nitrification and ammonification). $\mathrm{N}$ functional genes abundance is less sensitive parameter to reveal significant effects of forest biodiversity on $\mathrm{N}$ cycling at the early stage of afforestation compared to direct measurement of $\mathrm{N}$ cycling rates, and both parameters 
should be accounted. Forest composition affects microbial utilization of common LMWOS, but there is a knowledge gap regarding i) an appropriate review on the composition, content of fate of sugars in the soils, which are the main $\mathrm{C}$ and energy source of microorganisms and ii) effects of intrinsic properties of LMWOS (C oxidation state, molecular weight, number of $\mathrm{C}$ atoms) on their utilization by microorganisms. For the first question, a literature review has revealed that sugars are subjected to intensive recycling in soil: $80 \%$ of all sugars are recycled microbial compounds and only $20 \%$ are originated from plant biomass. For the second question, substances with C oxidation states varying from '0' (glucose, fructose and alanine) to '+0.5' (succinic acid), '+1' (glycine and malic acid) and ' +2 ' (formic acid) were studied. The $\mathrm{C}$ oxidation state of LMWOS correlated significantly with their half-life $\left(T_{1 / 2}\right)$ in soil solution, with more oxidized substances (formic acid) being utilized by microorganisms six times faster than less oxidized substances (sugars). In contrast, LMWOS-C oxidation state had no effect on the $T_{1 / 2}$ of $\mathrm{C}$ incorporated into microbial biomass due to cell metabolites produced from the initial LMWOS. The portion of mineralized LMWOS increased with their $\mathrm{C}$ oxidation state, being 4.5 times higher for formic acid compare to sugars, and corresponded to the decrease of $\mathrm{C}$ incorporated into microbial biomass and soil organic matter pools.

In conclusion, biotic factors such as tree species should be accounted when studying microbial community composition in forest soils. However, abiotic factors play a secondary role and are strongly mediated by biotic controls. To quantify the role of microbial functions for the decomposition of litter-derived organic compounds biochemical (enzyme activities) and molecular methods (e.g. functional gene abundance), as well as direct measurements of process rates (e.g. decomposition nitrification or ammonification rates), should be performed in combination and related to the molecular properties (e.g. C oxidation state) of the microbially utilized substances. 


\section{Zusammenfassung}

Mikroorganismen spielen die Schlüsselrolle für die meisten Umsatzprozesse im Boden. Deswegen werden Einflussfaktoren auf die Zusammensetzung, Funktion sowie Aktivität der mikrobiellen Gemeinschaft intensiv in der bodenkundlichen Forschung diskutiert. Diese Dissertation untersucht in Waldökosysteme die Relevanz von i) abiotischen (Temperatur und Niederschlag) und biotischen Einflussfaktoren (Baumart) auf die Zusammensetzung der mikrobiellen Gemeinschaft in Waldböden, ii) die Effekte der Biodiversität auf den mikrobiellen Abbau von organischen Polymeren der Pflanzenstreu und iii) den Einfluss der Struktureigenschaften häufig anzutreffender, niedermolekularer organischer Verbindungen auf deren mikrobielle Aufnahme und Metabolisierung.

Abiotische Faktoren beeinflussen die mikrobielle Zusammensetzung in Waldböden indirekt, d.h. über die Modifikation der Umweltbedingungen (Boden-pH, Kohlenstoff- und Stickstoffgehalte), sowie direkt mittels der pflanzlichen Nettoprimärproduktion, was entlang eines Klimagradienten in den Laubwäldern des Kilimandscharo untersucht wurde. Die biotische Beeinflussung mikrobieller Gemeinschaften wurde anhand des Vergleichs einer zehn Jahre alten Monokultur mit Mischwäldern unterschiedlicher Merkmale (d.h. Pioniergehölzen (Erle und Birke) im Vergleich zu Arten der späten Sukzession (Buche und Eiche), bzw. stickstofffixierenden (Erle) und nicht-stickstofffixierenden Arten (Birke, Buche und Eiche) eruiert, um so die direkte Wirkung der Streuqualität ohne die Beeinflussung edaphischer Faktoren zu untersuchen.

In allen untersuchten Kulturen beeinflusste Aufforstung die Entwicklung der pilzlichen Gemeinschaft (+50-200\% basierend auf Biomarker-Analysen) stärker als die der bakteriellen Gemeinschaften (+20-120\%), wobei die Effekte unter Monokulturen stärker als unter Mischkulturen waren. Deswegen wirkte sich der Arteffekt einzelner Baumspezies stärker als die Diversität des Bestandes auf die Zusammensetzung der mikrobiellen Gemeinschaft im Boden aus. Enzymsysteme, die verantwortlich für die Zersetzung von Streu sind, reagierten unterschiedlich auf die Aufforstung mit unterschiedlichen Baumarten. Selbst zwischen Enzymen, die Reaktionen im gleichen biogeochemischen Kreislauf ( $\mathrm{C}$ oder $\mathrm{N}$ ) katalysieren traten unterschiedliche Reaktionen auf. Die höchsten Aktivitäten von $\beta$-N-Acetylglucosaminidase, $\beta$-Xylosidase und saurer Phosphatase traten dort auf, wo sich Arten der frühen Primärsukzession (Birke) gemeinsam mit Arten der späteren Sukzession (Buche, Eiche) entwickelten und so synergistische Effekte erzeugten. Im Gegensatz dazu waren die Enzymaktivitäten in der Birkenmonokultur deutlich geringer. Die Wirkung der Diversität auf die Nährstoffkreisläufe wurde auch anhand der Abundanz funktioneller 
Gene für den N-Kreislauf, sowie anhand der Stickstoff-Umsatzraten (Brutto- und Nettonitrifikation bzw. Ammonifikation) bestimmt. Auch wenn funktionelle Genhäufigkeiten im Vergleich zur direkten Messung der N-Umsatzraten tendenziell weniger sensitiv bei der Bestimmung signifikanter Einflüsse der Diversität auf den N-Kreislauf in frühen Sukzessionstadien waren, so sollten doch beide Parameter gemeinsam betrachtet werden.

Die Baumartenzusammensetzung der Wälder beeinflusst auch die mikrobielle Nutzung niedermolekularer Substrate im Boden. Allerdings bestehen Wissenslücken bezüglich i) der Zusammensetzung, der Menge und dem Verbleib von Zuckern im Boden, obwohl diese als Hauptenergie- und Kohlenstoffquelle für Mikroorganismen gelten, sowie ii) der Folgen intrinischer Eigenschaften niedermolekularer organischer Substanzen (Oxidationsgrad des Kohlenstoffs, Molmasse, Anzahl von C-Atomen) auf deren mikrobielle Nutzung. Bezüglich der ersten Frage zeigte eine Literaturstudie, dass Zucker im Boden einer umfassenden Wiederverwertung unterliegen: $80 \%$ der Zucker stammen aus wiederverwendeten mikrobiellen Überresten und nur $20 \%$ entstammen der Pflanzenbiomasse. Für die zweite Fragestellung wurden Substanzen unterschiedlicher mittlerer Kohlenstoff-Oxidationszahlen von '0' (Glukose, Fruktose und Alanin), über Succinylsäure ('+0.5'), Glyzin und Maleinsäure ('+1') bis zur Ameisensäure ('+2') untersucht. Der Oxidationsgrad des Kohlenstoff war signifikant mit der Halbwertszeit der Verbindungen in der Bodenlösung korreliert, wobei Substanzen höherer Oxidationsgrade (Ameisensäure) sechs Mal schneller als solche niedrigerer Oxidationsgrade (Zucker) mikrobiell verwertet wurden. Im Gegensatz dazu hatte der Oxidationsgrad der niedermolekularen Verbindungen keinen Einfluss auf die Halbwertszeit des in die mikrobielle Biomasse eingebauten Kohlenstoffes und somit der mikrobiellen Metabolite, die aus der initialen Kohlenstoffquelle gebildet wurden. Der Mineralisierungsgrad unterschiedlicher Substrate stieg mit dem Oxidationsgrad an: Essigsäure wurde 4.5 mal mehr veratmet als die Zucker, was im Gegenzug mit der Abnahme des C-Einbaus in die mikrobielle Biomasse oder in andere Pools organischer Substanzen einher ging.

Zusammenfassend sollten biotische Faktoren wie die Baumart in Untersuchungen der mikrobiellen Gemeinschaft in Waldböden integriert werden, wohingegen abiotische Faktoren eher eine untergeordnete Rolle spielen und von biotischen Einflussgrößen massiv abgemildert werden. Zur Quantifizierung der Bedeutung mikrobieller Funktionen für den Abbau streubürtiger Substanzen sollten biochemische (Enzymaktivitäten) und molekularbiologische Methoden (z.B. Abundanz funktioneller Gene) sowie direkte Messungen von Umsatzraten (z.B. AbbauNitrifikations- oder Ammonifikationsraten) in Kombination angewandt und gemeinsam mit 
molekularen Eigenschaften wie der mittleren Oxidationszahl der mikrobiell-genutzen Verbindung betrachtet werden. 


\section{Acknowledgements}

I would like to acknowledge to the Erasmus Mundus Joint Doctoral Programme "Forest and Nature for Society" (FONASO) the funding for my PhD work. I would also like to thank the Sêr Cymru National Research Network for Low Carbon Energy and Environment for supporting the BangorDIVERSE experiment, which I used extensively within my studies. Part of the work was done in collaboration with my colleague - Joscha Nico Becker, who kindly provided me the samples from the Kilimanjaro Ecosystems study, which was supported by grants from the German Research Foundation (DFG) within Project KU 1184/20-2 and /20-3 of the Research-Unit 1246 (Kilimanjaro Ecosystems under Global Change).

This project was supervised by Prof. Yakov Kuzyakov and Prof. Davey Jones. I am really grateful to both of them for their big contribution to my education and future career. I am thankful because they gave me great possibilities and chances to develop my creativity and scientific thinking and always supported my work.

I am thankful to my family, who supported my willing to go abroad to get my PhD degree and especially to my mother and father, who was always on the phone to listen to all my difficulties and problems. 


\section{List of articles}

This thesis is based on the following articles:

I. Anna Gunina, Joscha Nico Becker, Andreas Hemp, Luo Yu, Davey L. Jones and Yakov Kuzyakov. (2017). Determining the optimal temperature and precipitation for microbial community development in montane forest ecosystems: PLFA analysis along a $3500 \mathrm{~m}$ altitudinal gradient on Mt Kilimanjaro. Unpublished manuscript.

II. Anna Gunina, Andrew R. Smith, Douglas L. Godbold, Davey L. Jones and Yakov Kuzyakov. (2017). Response of soil microbial community to afforestation with pure and mixed species. Plant and Soil 412: 357-368

III. Anna Gunina, Kristina Syundyukova, Andrew R. Smith, Davey Jones and Yakov Kuzyakov. (2017). Effects of afforestation on enzyme activities in soil. Unpublished manuscript.

IV. Relena R. Ribbons, Anna Gunina, Andy R. Smith, Lars Vesterdal, Morag A. McDonald, Yakov Kuzyakov and Davey L. Jones. (2017). Microbial nitrogen cycling gene abundance does not reflect nitrogen processing rates in forest soils. Unpublished manuscript.

V. Anna Gunina and Yakov Kuzyakov. (2015). Sugars in soil and sweets for microorganisms: Review of origin, content, composition and fate. Soil Biology and Biochemistry. 90: 87-100.

VI. Anna Gunina, Andrew R. Smith, Yakov Kuzyakov and Davey L. Jones (2017). Microbial uptake and utilization of low molecular weight organic substrates in soil depend on carbon oxidation state. Biogeochemistry. 133: 89-100. 


\section{Chapter 1. General introduction and rationale}

\subsection{General introduction}

Forests represent unique ecosystems, where half (for the tropics) to $85 \%$ (for the boreal zone) of $\mathrm{C}$ is stored in the soil (Dixon et al., 1994). As in other ecosystems, microorganisms play a leading role in the function of forest soils by regulating nutrient cycles, as well as contributing directly to the formation and stabilization of soil organic matter (SOM). Climatic variables can affect the composition of soil microbial communities directly as well as indirectly, by regulating the type and productivity of plant communities. On the other hand, plant litter and root exudates create specific conditions for the development of specific microorganisms, depending on the plant community type. Thus, one of the central topics regarding the functioning of forest soils is the contribution of abiotic and biotic factors to the formation and function of microorganisms.

One of the open questions related to the formation of soil microbial communities is the effect of abiotic factors, such as temperature and precipitation. It has been shown that mean annual precipitation (MAP) has a strong positive effect on the richness of fungal communities (Tedersoo et al., 2014), and the closer an ecosystem is located to the equator, the richer the fungal soil community becomes (Tedersoo et al., 2014). Also, the composition of a bacterial community can be explained by the range in mean annual temperature (MAT) and MAP (Griffiths et al., 1999; Xu et al., 2014). Climatic factors strongly affect the productivity of plant communities as well as soil chemical properties, which both impact microbial community composition. Thus, there is still a knowledge gap regarding how climatic factors alone contribute to the formation of soil microbial communities. To address this question, mature soils formed under natural forests, on similar parent material, and within the same time frame should be studied, where strong variations in MAT and MAP can be found within a short distance. These conditions can be met in mountain ecosystems.

Previous studies have shown that compositionally distinct soil microbial communities can be formed under various forest types (e.g. beech, oak, and pine), which is directly related to the quantity and quality of plant litter and root exudates (Hackl et al., 2005). On the other hand, it has been shown that edaphic factors, such as soil pH, clay content (Scheibe et al., 2015), as well as the age of the forest (Banning et al., 2011), can affect microbial community composition. Thus, it is hard to separate the effect of the plant species itself from the effect of environmental factors on the formation of soil microbial community composition in forests. It is known that changes in soil chemical properties typically occurs over several decades, whereas the quality of plant inputs 
changes almost immediately after forest establishment. Therefore, to reveal the effect of tree species composition on microbial community structure, young forests should be studied.

The function of soil microbial communities can be estimated by i) their ability to break down and recycle complex organic compounds (Razavi et al., 2016), as well as by ii) the subsequent utilization of the decomposition products formed during this process (Boddy et al., 2007) (low molecular weight organic substances (LMWOS)). Follow forest establishment, significant changes in the quality and quantity of organic matter inputs, as well as edaphic conditions and cycles of all essential nutrients, such as carbon $(\mathrm{C})$, nitrogen $(\mathrm{N})$ and phosphorus $(\mathrm{P})$, are strongly modified. Soil enzymes serve as good indicators for shifts in nutrient cycling rates and are believed to react rapidly to changes in environmental conditions (Bandick and Dick, 1999). However, how tree species with different functional traits (i.e. $\mathrm{N}$-fixing $v s$ non-N-fixing, early primary $v s$ late successional species) and their combinations affect soil enzymatic systems is still an open question. Moreover, it is unclear how the rates of these processes (e.g. nitrification) are altered after afforestation with various tree species and which parameters (e.g. direct measurements of the processes rates or functional genes abundance) reflect these changes.

Utilization of LMWOS by microorganisms has been studied intensively during the last 20 years (Boddy et al., 2007; Farrar et al., 2003; Grayston et al., 1997). However, most of the previous studies have focused on the utilization of LMWOS with respect to soil type (Jones, 1999), plant community composition (Gunina and Kuzyakov, 2015), and C substrate concentration (Schneckenberger et al., 2008). In contrast, the intrinsic properties of the LMWOS, such as substance type and their physiochemical properties (e.g. oxidation state, number of $\mathrm{C}$ atoms and number of $\mathrm{COOH}$ groups) has not received much attention. In addition, there is a knowledge gap regarding the content, composition, and fate of many types of LMWOS.

This thesis therefore contains several studies which address the knowledge gaps highlighted above, specifically regarding the effect of abiotic (temperature and precipitation) and biotic (plant biodiversity) factors on microbial community formation and function in forest soils. Lastly, some new research directions are presented on the fate of LMWOS in soil.

\subsection{Thesis plan}

The thesis consists of nine chapters, which address scientific gaps regarding the formation and function of the microbial community in forest soils, as well as the fate of LMWOS. Chapter one provides a general introduction to the research topics investigated in the $\mathrm{PhD}$. Chapter 
two provides a short literature review on the knowledge gaps regarding formation and function of microbial communities in forest soils and the fate of LMWOS. In Chapter three (Fig. 1-1), research results are presented regarding the effect of environmental factors on the structure of soil microbial communities, which was investigated using plots allocated along the Mt. Kilimanjaro (3500 m) elevation gradient under natural deciduous vegetation. In chapter four (Fig. 1-1), research results regarding the effect of monoculture and mixed species forests (presented by species with various functional traits) on the formation of soil microbial communities are described for young afforested stands at the BangorDiverse field experiment. Both studies were performed using a molecular biomarkers technique, namely phospholipid fatty acids (PLFAs), to reveal microbial community composition patterns. Chapter five (Fig. 1-1) focuses on the function of microorganisms and activities of soil enzymes responsible for the C, N, and P cycling in forest soils formed under various tree species. In chapter six (Fig. 1-1), the comparison of two methods, namely direct measurement of $\mathrm{N}$ process rates and $\mathrm{N}$-functional genes abundance, is made to reveal which approach is more valuable for revealing changes in $\mathrm{N}$ cycling in soils under different forest types. Both studies used soil samples collected at the BangorDiverse experimental site. Chapters seven and eight (Fig. 1-1) focus on the uptake of LMWOS by microorganisms, their utilization, and mineralization. This work was divided into two parts: i) a review study on one class of LMWOS sugars (chapter seven), and ii) an investigation of sugar, carboxylic acid, and amino acid utilization by microorganisms (chapter eight). The review focuses on the content, composition and fate of sugars in the soil, including the possible contribution of sugar-derived $\mathrm{C}$ to the soil solution and SOM composition. Based on this review, the second part of the work was performed (chapter eight) to reveal the fate of three different LMWOS classes (i.e. sugars, carboxylic acid, and amino acids) in soil, but with the main focus on their properties. In chapter nine, the main conclusions from the work are presented, as well as future directions for research associated with the topics investigated in the thesis. 


\section{Formation of soil microbial community structure}

\section{Microorganisms functioning}

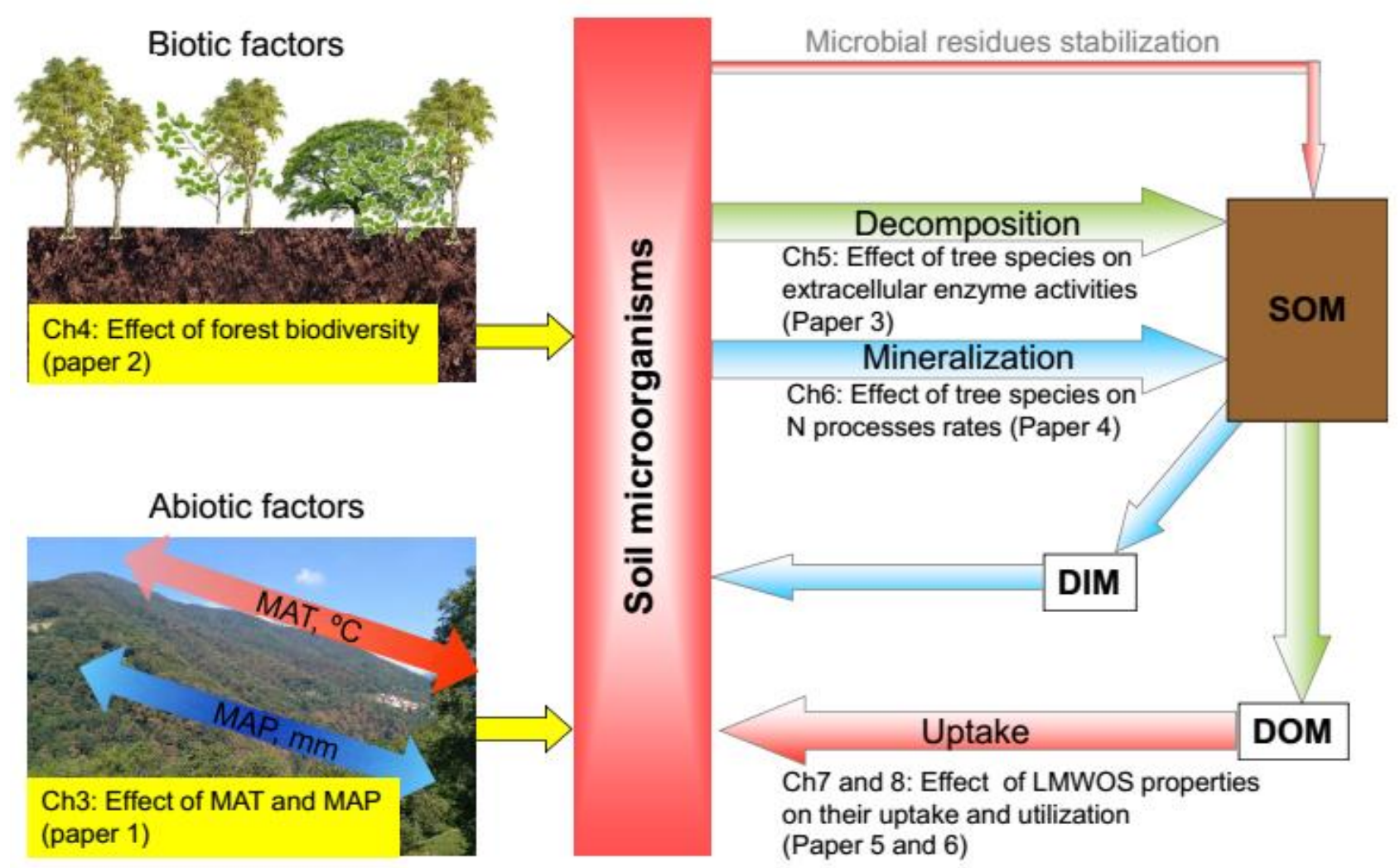

Figure 1-1. Schematic overview of experimental chapters (Ch) of the PhD. Processes contributing to the formation of soil microbial community structure and activity in forest soils are presented. SOM - soil organic matter, DIM - dissolved inorganic matter, DOM - dissolved organic matter.

\subsection{Thesis objectives}

The objectives of the thesis were:

1) To reveal the effect of abiotic (i.e. temperature and precipitation) and biotic (i.e. plant community type) factors on the formation of microbial communities in forest soils (chapter 3 and 4);

2) To reveal changes in the function of soil microbial communities after afforestation, with the main focus on i) utilization of organic polymers of plant litter by estimation of soil enzymatic activity (chapter 5) and ii) N cycling (chapter 6); 
3) To reveal the fate of a particular class of LMWOS (sugars) in soil in terms of their long and short-term dynamics (chapter 7), as well as estimate how substance properties can affect the fate of LMWOS-C in soil for the three main LMWOS classes (chapter 8).

\subsection{Methods employed}

Table 1 provides a summary of the main methods used within the $\mathrm{PhD}$.

Table 1-1. Summary of the methods used in the PhD.

\begin{tabular}{|c|c|c|}
\hline Measured parameter & Method & Reference/Equipment \\
\hline $\begin{array}{l}\text { Structure of soil microbial } \\
\text { communities }\end{array}$ & $\begin{array}{l}\text { Phospholipid fatty acids } \\
\text { Liquid-liquid extraction } \\
\text { GC-MS/GC-C-IRMS } \\
\text { DNA extraction }\end{array}$ & (Frostegard et al., 1991) \\
\hline $\begin{array}{l}\text { Activity of soil microbial } \\
\text { communities }\end{array}$ & $\begin{array}{l}\text { Enzyme activities by addition of } \\
\text { fluorogenic substrates. }\end{array}$ & $\begin{array}{l}\text { (Dorodnikov et al., 2009; } \\
\text { Sanaullah et al., 2011) }\end{array}$ \\
\hline $\begin{array}{l}\text { Functions of soil microbial } \\
\text { communities }\end{array}$ & $\begin{array}{lll}\begin{array}{l}\text { Nitrogen } \\
\text { abundance }\end{array} & \text { functional } & \text { genes } \\
\end{array}$ & (Braker et al., 1998) \\
\hline $\begin{array}{l}\text { Utilization of }{ }^{14} \mathrm{C} \text { labelled } \\
\text { LMWOS by microorganisms }\end{array}$ & $\begin{array}{l}\text { Soil solution extraction by } \\
\text { centrifugation } \\
\text { Liquid scintillation counting by } \\
\beta \text {-spectrometry }\end{array}$ & $\begin{array}{l}\text { (Glanville et al., 2012) } \\
\text { Microbeta, Beckmann } 6500\end{array}$ \\
\hline Microbial biomass $\mathrm{C}$ & Fumigation-extraction procedure & (Vance et al., 1987) \\
\hline $\begin{array}{l}\text { Ammonification, gross } \mathrm{N} \\
\text { mineralization, net } \mathrm{N} \\
\text { mineralization }\end{array}$ & $\begin{array}{l}\text { Aerobic and anaerobic soil } \\
\text { incubations }\end{array}$ & (Mulvaney, 1996) \\
\hline $\begin{array}{l}\mathrm{NO}_{3}{ }^{-} \text {and } \mathrm{NH}_{4}^{+} \text {concentrations in } \\
\text { soil solution }\end{array}$ & Spectrophotometry & (Mulvaney, 1996) \\
\hline $\mathrm{pH}$ & & Glass Electrodes, Orion U402-S7 \\
\hline Total $\mathrm{C}$ and $\mathrm{N}$ & Dry combustion & Analytic Jena \\
\hline
\end{tabular}




\section{Chapter 2. Literature Review}

\subsection{Features of forest ecosystems and forest soils}

\subsubsection{Differences between forest and agricultural soils}

Forest ecosystems have an area of around 4.1 billion ha, which is 2.7 times higher than agricultural ecosystems (1.5 billion ha) (Lal, 2005). Environmental conditions in forest ecosystems are completely different from those in agricultural systems: i) plant litter (above as well as belowground) remains in situ within forests, leading to much higher $\mathrm{C}$ inputs compared to agricultural ecosystems, and ii) forest ecosystems are not subjected to tillage, leaving the soil structure undisturbed. Both factors promote much higher $\mathrm{C}$ accumulation in an ecosystem, especially within the soil component.

Besides higher $\mathrm{C}$ accumulation, other properties of forest soils are also different from those under agricultural management. Firstly, forest litter is rich in recalcitrant substances such as lignin, cellulose and waxes (Johansson, 1995), which leads to its slower decomposition in comparison to crop residues and promotes its net accumulation. Secondly, trees provide higher amounts of root exudates than annual plants: $60 \%$ of the assimilated $\mathrm{C}$ of Scots pine are transferred belowground annually vs. 10-40\% for annual plants (Grayston et al., 1997). Thirdly, even if the composition of tree root exudates is similar to the exudates of annual plants, some compounds are only found in forests, including aconitic, gluconic, oxaloacetic, abietic and shikimic acids (Grayston et al., 1997). The abundance of organic acids in root exudates acidifies forest soils (Fu et al., 2015) and increases migration of nutrients through the soil profile. Fourthly, the moisture content of forest soils is typically higher than that of cropland due to shading of the soil surface, which reduces evaporation and affects tree root architecture. Thus, specific conditions are present in the forest soils which make all processes and element cycling different from those in agricultural ecosystems.

\subsubsection{Effect of afforestation on soil properties}

After forest establishment, a cascade of processes occurs in soil, which progressively shifts its physical and chemical properties. Bulk density decreases (Korkanç, 2014) due to an increase in the density of root systems, total porosity increases (Korkanç, 2014), and the proportion of macroaggregates increases (An et al., 2010) as a response to the absence of tillage. Soil C stocks gradually increase with forest age (Alriksson and Olsson, 1995; Lima et al., 2006; Romanyà et al., 2000). Specifically, the proportion of particulate organic matter (POM) increases from 5 to $30 \%$ after seven years of forest growth (Besnard et al., 1996). Soil pH decreases as a result of high 
organic acid content in the root exudates, as well as strong uptake of cations by growing trees (Fu et al., 2015). The quality of SOM is also changed: the C/N ratio of SOM increases due to the input of forest litter with a wide $\mathrm{C} / \mathrm{N}$ ratio, including a high input of lignin, cellulose, and tannins.

Changes to soil properties following afforestation occur at different rates: $\mathrm{C}$ and $\mathrm{N}$ stocks generally increase with forest age and achieve maximum accumulation rates during the exponential tree growth phase (DeLuca and Boisvenue, 2012), and gradually decline in late successional stage forests. Approximately 30-50 years after afforestation, C and N stocks become stabilized (Fu et al., 2015; Kalinina et al., 2011). The reported $\mathrm{pH}$ decrease for 27-year-old forests was around 0.95 units (Fu et al., 2015), and 80-100 years of forest development is required to obtain $\mathrm{pH}$ values close to the level found in old growth forest soils (Ritter et al., 2003).

Thus, even though several processes and shifts in soil chemical and physical properties occurs after afforestation, they can not serve as indicators for modification of the soil environment at the early stage of forest development.

\subsubsection{Afforestation and soil microorganisms}

Usually the content of microbial biomass in forest soils in two times higher compared to agricultural soils (Zhang et al., 2017). Changes in soil physical and chemical properties following afforestation stimulate soil microbial biomass development (Yang et al., 2014). However, in contrast to soil chemical properties, the composition of microbial communities can stabilize already during the first years after forest establishment (Yang et al., 2014). However, diverse responses of particular microbial groups to afforestation have been observed. Contents of bacteria and fungi (based on the analysis of microbial biomarkers) were reported to be higher for 7-year-old forests compare to 1-year-old plots (Yang et al., 2014). Increases of both bacterial and fungal biomarker contents were found for 15-year-old coniferous forest stands (Deng et al., 2016). 27 years after afforestation, contents of fungal and arbuscular mycorrhizal fungi (AMF) biomarkers were higher in broadleaf and Cunninghamia forests compared to a pine forest (Fu et al., 2015). In contrast, only weak differences were found for the content of bacterial biomarkers for 27-years-old coniferous and deciduous forests (Fu et al., 2015), and only trends of increasing fungal biomass were observed for the 18-year-old Eucalyptus forests (Cavagnaro et al., 2016).

Thus, even if afforestation promotes an increase in microbial biomass and the content of particular microbial groups, the changes depend on the forest type. Furthermore, simultaneous changes of the soil chemical and physical properties, especially at the late stage of forest 
development, prevents the direct effect of forest development on the formation of soil microbial communities from being distinguished.

\subsection{Microbial community composition in forest soils}

\subsubsection{Effect of forest type on the structure of soil microbial communities}

Besides the formation of specific conditions in soils after afforestation and stimulation of microorganism growth, tree species can promote the development of specific microbial communities (Hackl et al., 2005; Vivanco and Austin, 2008). For example, compared to broadleaf forests, the presence of coniferous trees stimulates fungal biomass (Hackl et al., 2005). This is directly linked to differences in litter quality: the litter quality of broadleaf species (estimated by the $\mathrm{C} / \mathrm{N}$ ratio) is high compared to coniferous species (Guo et al., 2016), and therefore this litter is more easily degraded by microorganisms. In contrast, coniferous needles contain high amounts of lignin and tannins, which are mainly utilized by fungi (Hackl et al., 2005). Similar results can also be found within deciduous species: various microbial communities were formed under beech, hornbeam, lime and maple forests (Scheibe et al., 2015), which was explained by the quality of litter and soil $\mathrm{P}$ content. Moreover, beech forests were shown to affect soil $\mathrm{pH}$, which can additionally affect the composition of soil microbial communities and increase the presence of fungi (Scheibe et al., 2015). Implementation of azonal forest types, such as a floodplain formed by Nfixing alder, leads to the development of microbial communities that are compositionally distinct from those formed under oak, beech and spruce-fir-beech forests. The floodplain forest showed the development of AMF and gram-negative bacteria as a response to high nutrient content (Hackl et al., 2005). In contrast, no differences in soil microbial communities were found between non-Nfixing fir and N-fixing alder (Boyle et al., 2008); however, various microbial communities were found under two N-fixing genera: Acacia dealbata and Acacia implexa (Hoogmoed et al., 2014). Beside species effects, forest diversity affects microbial community structure. This was found for beech growing in monoculture versus in mixtures with other trees (Scheibe et al., 2015). Thus, it is still unclear how various tree species, as well as simultaneous development of species with various functional traits, contribute to soil microbial community structure composition.

\subsubsection{Effect of abiotic factors on the structure of soil microbial communities}

Besides the effect of tree species itself and reaction to the changes of soil chemical and physical properties, such factors as season, MAT and MAP can contribute to the composition of soil microbial communities. The effect of season can de direct (e.g. changing temperature and 
precipitation between seasons), but also indirect (e.g. connected with different types of litter inputs in summer and autumn) (Kaiser et al., 2011, 2010; Koranda et al., 2013). It was shown that the microbial community in winter contrasts strongly with the summer community (Koranda et al., 2013), especially in terms of functional properties. The winter community was more adapted to the degradation of plant residues (cellulose, hemicellulose, and other polymers in litter), whereas the summer community was more responsible for the degradation of easily available substances in root exudates (Kaiser et al., 2010; Koranda et al., 2013).

At the global scale, MAP has a great effect on the diversity of fungal communities (Tedersoo et al., 2014). More diverse saprotrophic fungal communities were found in the tropics, whereas ectomycorrhizal fungi were favored in temperate and boreal ecosystems (Tedersoo et al., 2014). For the diversity of bacterial communities, environmental factors, such as MAT and potential evapotranspiration, did not have a great effect and soil $\mathrm{pH}$ was mainly responsible for variability (Fierer and Jackson, 2006). In contrast, an effect of climatic variables on bacterial diversity was found in the mountain forests: a negative effect of MAP was shown for the elevation gradient of 540-2360 $\mathrm{m}$ in a temperate monsoon climate, whereas a positive effect of temperature was observed (Xu et al., 2014). In another study, bacterial diversity was strongly correlated with MAP along a 100-1950 m elevation gradient in a moist, subtropical climate (Singh et al., 2014). In contrast, MAP had a rather weak effect in a humid continental climate, whereas the effect of MAT was prevailing (Xu et al., 2014). However, due to the strong link between climatic variables, plant community type and environmental conditions, it is still unclear if the effect of climatic variables on the microbial community composition is direct or results from changes to vegetation type and modulation of soil chemical properties.

\subsection{Function of microbial communities in forest soils}

\subsubsection{Utilization of complex plant polymers}

Utilization of organic polymers by microorganisms does not occur directly, but rather is achieved by extracellular enzymes produced by microorganisms (Tischer et al., 2015). Activity of extracellular enzymes reacts to the changes in environmental factors, such as temperature (Razavi et al., 2016), soil moisture (Sanaullah et al., 2011), pH, content of available and total C and N (Finzi et al., 2015), as well as land use change (Ren et al., 2016) and season (Kaiser et al., 2010). All of these factors can shift microbial community structure and thus, production and type of extracellular enzymes. 
Table 2-1. Enzyme activities determined in soil science research.

\begin{tabular}{|c|c|c|}
\hline Enzyme & Role in soil processes & Reference \\
\hline \multicolumn{3}{|c|}{ C cycle } \\
\hline Amylase & Hydrolysis of starch & (Ross, 1983) \\
\hline Cellulase & $\begin{array}{l}\text { Decomposition of cellulose and some } \\
\text { related polysaccharides }\end{array}$ & (Grosso et al., 2014) \\
\hline Xylanase & Breakdown of hemicellulose & (Razavi et al., 2016) \\
\hline$\beta$-glucosidase & $\begin{array}{l}\text { Catalyzes the hydrolysis of the glycosidic } \\
\text { bonds to create terminal non-reducing } \\
\text { residues in beta-D-glucosides and } \\
\text { oligosaccharides }\end{array}$ & (Razavi et al., 2016) \\
\hline Catalase & $\begin{array}{l}\text { Decomposition of hydrogen } \\
\text { peroxide to water and oxygen }\end{array}$ & (Ren et al., 2016) \\
\hline Saccharase & Hydrolysis of sucrose & (Ren et al., 2016) \\
\hline Phenol oxidase & $\begin{array}{l}\text { Catalyses the } o \text {-hydroxylation of } \\
\text { monophenol molecules }\end{array}$ & (Das and Varma, 2010) \\
\hline \multicolumn{3}{|c|}{ N cycle } \\
\hline N-Acetyl- $\beta$-d-glucosaminidase & Hydrolysis of chitin & (Fatemi et al., 2016) \\
\hline Leucine aminopeptidase & $\begin{array}{l}\text { Hydrolysis of leucine residues at the N- } \\
\text { terminus of peptides and proteins }\end{array}$ & (Razavi et al., 2016) \\
\hline Chitinases & Breakdown of glycosidic bonds in chitin & (Burns et al., 2013) \\
\hline Urease & $\begin{array}{l}\text { Hydrolysis of urea into carbon dioxide and } \\
\text { ammonia }\end{array}$ & $\begin{array}{l}\text { (Kujur and Kumar Patel, } \\
\text { 2014) }\end{array}$ \\
\hline \multicolumn{3}{|c|}{ P cycle } \\
\hline Acid phosphatase & $\begin{array}{l}\text { Decoupling of phosphoryl groups during } \\
\text { digestion }\end{array}$ & (Ren et al., 2016) \\
\hline Alkaline phosphatase & $\begin{array}{l}\text { Produced mainly by plants for the } \\
\text { mineralization of organic } \mathrm{P}\end{array}$ & (Dick et al., 2000) \\
\hline
\end{tabular}

The most frequently presented parameter in studies dedicated to soil enzyme activities is the $\mathrm{V}_{\max }$, the maximal velocity of enzyme catalysis, which reflects decomposition rates at saturating substrate concentrations. At the global scale, activities of $\beta$-glucosidase and N-Acetyl- $\beta$-dglucosaminidase (estimated by $\mathrm{V}_{\max }$ ) were reported to be higher in temperate forests compared with 
tropical and subtropical forests (Xu et al., 2017). In contrast, acid phosphatase activity had opposite trend as a reaction to low $\mathrm{P}$ availability in tropical area (Herbert et al., 2003). For temperate forests, high $\beta$-glucosidase activity was reported in the soil formed under beech forest compared to oak (Grosso et al., 2014), and under pine compared to spruce and birch forests (Adamczyk et al., 2014); $o$-diphenol oxidase activity was lower in beech forests compared to oak (Grosso et al., 2014); NAcetyl- $\beta$-d-glucosaminidase and acid phosphatase activities were similar for pine, spruce and birch forests (Adamczyk et al., 2014). Observed variations in enzyme activities under various tree species are explained by i) quantity and quality of plant residues (in the case of cellulase), ii) variability of soil microbial communities (in the case of chitinase), iii) differences in SOC content (for proteases) and iv) soil pH (for acid phosphatase) (Grosso et al., 2014). Afforestation increases the rate of catalase, saccharase, urease, and alkaline phosphatase activity, which occurs as a response to increased substrate concentrations, including root exudates (Ren et al., 2016), leaf litter, and root litter, or as a response to nutrient competition between growing trees and microorganisms.

The second important parameter used to characterize soil enzymes is the enzyme affinity to the substrate (the so-called Michaelis constant, $\mathrm{K}_{\mathrm{m}}$ ), which is the substrate concentration at half the maximal enzymatic rate. Substrate affinity is also changed by afforestation: the affinities of $\alpha$ glucosidase and $\beta$-cellobiohydrolase have been shown to decrease after the conversion of pasture to forest (Tischer et al., 2015), whereas xylanase affinity was not effected (Tischer et al., 2015).

In addition, the ratio of of $V_{\max }$ to $K_{m}$ can be calculated, which reflects catalytic efficiency of enzymes. This ratio can be used as an estimation of microbial community response to changing environments, as well as a switch between microbial metabolism strategies. Catalytic efficiency of enzymes was higher for forest soils compared to grassland and agricultural soils (Kujur and Kumar Patel, 2014), and depended on soil properties, nutrient availability (Tischer et al., 2015) and the source of the enzyme substrate (Ryan et al., 2001). Thus, even though there is research about the activities of extracellular enzymes in forest soils, there is still a lack of information regarding the effect of afforestation on enzyme function, and no studies regarding the effect of trees with various functional traits on kinetic parameters of enzymes.

\subsubsection{Utilization of LMWOS}

The LMWOS comprise 5-10\% of the total dissolved organic C in soil (Ryan et al., 2001). The concentrations of the main LMWOS classes usually range between 1-1000 $\mu \mathrm{M}$ for sugars, 1 to $1800 \mu \mathrm{M}$ for carboxylic acids (Strobel, 2001) and 0.1-50 $\mu \mathrm{M}$ for amino acids (Monreal and McGill, 1985). Despite low concentrations, LMWOS play an important role in the soil function: they are the 
main energy, C, and N sources for microorganisms (Gunina et al., 2014; Gunina and Kuzyakov, 2015), participate in P immobilization (Palomo et al., 2006), and act as stimulators or inhibitors of microbial activity (Blum, 1998). In contrast to organic polymers, LMWOS can be taken up by microorganisms directly and further utilized within the microbial cells (Apostel et al., 2013). The LMWOS can be used for energy production, as well as for the synthesis of cell components. The former leads to mineralization of LMWOS-C to $\mathrm{CO}_{2}$, while the latter results in the stabilization of LMWOS-C within the microbial biomass, and later can contribute to SOM composition.

The fate of LMWOS in soil was intensively studied in the last 20 years (Glanville et al., 2016; Jones, 1998; Schneckenberger et al., 2008), with the main focus on mineralization after vegetation change (Brant et al., 2006), for determination of community level physiological profile of microorganisms (Degens and Harris, 1997), as well as to determine the effect of substance concentration on utilization pattern (Schneckenberger et al., 2008). Despite the intensive investigation, these is still a lack of information regarding the effect of i) substance class and ii) substance physicochemical properties on the fate of LMWOS in soil, including uptake from the soil solution, mineralization, and utilization for microbial biomass construction. Moreover, only few studies have investigated the rates of both uptake of LMWOS from soil solution and decomposition within the microbial cells simultaneously.

Regarding the effect of substance class, there is a knowledge gap about the composition, content and fate of sugars in the soil. Despite knowledge that sugars are the main source of $\mathrm{C}$ and energy for microorganisms in soil and their intensive application for priming studies and estimation of microbial biomass content, no review on sugars has been done in the last 50 years.

Regarding the second question, the effects of substance properties on their uptake and utilization by microorganisms were not intensively investigated. Presently, it is known that the fate of LMWOS in soil solution is regulated by microbial uptake and depends on the substance class (Apostel et al., 2013; Gunina et al., 2014) and their concentrations (Hill et al., 2008). In addition, the presence of charges on LMWOS molecules can lead to their sorption on mineral soil phases (mainly in tropical soils), which is valuable for the charged amino acids and carboxylic acids. An effect of $\mathrm{C}$ oxidation state on uptake by microorganisms was also reported for amino acids (Jones and Hodge, 1999). Recently, solubility was shown to effect the fate of carboxylic acids in soil (Gunina et al., 2014). Thus, besides substance class, the physicochemical properties of an individual compound can also play a great role in the fate of LMWOS in soils. 
Properties of the substances can also effect LMWOS utilization within microbial metabolic cycles. It is known that each compound class enters distinct metabolic cycles within the cell (Lengeler et al., 1999); however, it was shown that a higher amount of carboxyl groups (-COOH, C oxidation state $=+3.0)$ than methyl groups $\left(-\mathrm{CH}_{3}, \mathrm{C}\right.$ oxidation state $\left.=-3.0\right)$ are mineralized to $\mathrm{CO}_{2}$ (Fischer and Kuzyakov, 2010). Therefore, the presence of a high number of reduced $\mathrm{C}$ atoms in LMWOS molecules can lead to low mineralization and high LMWOS-C incorporation into structural elements of the cell. At the same time, a higher proportion of mineralized $\mathrm{C}$ should be observed for substances with a high number of oxidized $\mathrm{C}$ atoms (e.g. substrates rich in -COOH groups). Additionally, the standard enthalpy of combustion of organic compounds seems to be dependent on substance $\mathrm{C}$ oxidation state: for substances with a " 0 " C oxidation state (e.g. glucose, alanine), the values of standard enthalpy of combustion are in the range $1600-2800 \mathrm{~kJ} / \mathrm{mol}$, whereas for oxidized substances (C oxidation state +1 or +2 ), the values are lower: $280-1300 \mathrm{~kJ} / \mathrm{mol}$. Thus, substance physio-chemical properties can directly impact the utilization processes of LMWOS within microorganisms (Schimel and Schaeffer, 2012). In contrast, the fate of C contained within LMWOS may be closely related to cell metabolite turnover, where this $\mathrm{C}$ was incorporated during intercellular metabolisation (Glanville et al., 2016).

Thus, based on the literature review, the main knowledge gaps for the aforementioned topics were determined to be: i) the effect of abiotic factors (MAT and MAP) on the structure of soil microbial communities; ii) the effect of a biotic factor (i.e. forest composition) on the structure of microbial communities; iii) the function of microorganisms in forest soils (with the main focus on plant polymer utilization and process rate estimation); iv) the fate of LMWOS in soils (with the main focus on the substance properties) and $v$ ) the absence of a proper literature review about the content, composition, and fate of sugars in the soils. 


\section{Chapter 3 Article I Determining the optimal temperature and precipitation for microbial community development in montane forest ecosystems: PLFA analysis along a $3500 \mathrm{~m}$ altitudinal gradient on Mt Kilimanjaro}

Anna Gunina ${ }^{1,2}$, Joscha Nico Becker ${ }^{3, a}$, Andreas Hemp ${ }^{4}$, Luo Yu ${ }^{5}$, Davey L. Jones ${ }^{1}$ and Yakov

$$
\text { Kuzyakov }^{2,5}
$$

${ }^{1}$ School of Environment, Natural Resources and Geography, Bangor University, Bangor, UK

${ }^{2}$ Department of Agricultural Soil Science, Georg-August University of Göttingen, Göttingen, Germany

${ }^{3}$ Department of Soil Science of Temperate Ecosystems, Georg-August-University Göttingen, Göttingen, Germany

${ }^{4}$ Department of Plant Systematics, University of Bayreuth, Germany

${ }^{5}$ Institute of Soil and Water Resources and Environmental Science, Zhejiang Provincial Key

Laboratory of Agricultural Resources and Environment, Zhejiang University

\section{Unpublished manuscript}

Author contributions: Anna Gunina and Joscha Nico Becker contributed equally to this work. All other authors contributed to the final version of manuscript.

Key words

Climate effects, Elevation gradient, Environmental variables, PLFAs,

Microbial community structure, Ecological niche differentiation 


\section{Abstract}

Climate is crucial in controlling and shaping the development of mountain ecosystems, including vegetation and soils. Strong interactions between climatic variables, plant communities and edaphic properties, however, make it difficult to evaluate the main factors controlling soil microbial community structure. We used the unique elevation gradient of Mt. Kilimanjaro along a $3500 \mathrm{~m}$ altitudinal transect to determine the effects of a) mean annual temperature (MAT: from +4.7 to $+23.7^{\circ} \mathrm{C}$ ), b), mean annual precipitation (MAP: from 845 to $3000 \mathrm{~mm}$ ), and c) edaphic factors on the size and composition of the soil microbial community. Topsoil samples $(0-10 \mathrm{~cm})$ were collected from six natural forest ecosystems from 740 to $4190 \mathrm{~m}$ a.s.l. Microbial community structure was assessed by phospholipid fatty acid (PLFA) profiling. To contextualize our results, this was supported by a global review of the effects of MAP and MAT on the size of the soil microbial biomass in soils from mountain forest ecosystems in humid continental, humid subtropical, temperate continental, monsoon, and semiarid climates. Our results showed that total PLFA content had a bell shape pattern being maximal at $2120 \mathrm{~m}$ ( $2 \mu \mathrm{mol} \mathrm{g}^{-1}$ soil), which is explained by an optimal combination of temperature $\left(+12{ }^{\circ} \mathrm{C}\right)$ and precipitation $(3000 \mathrm{~mm})$. The minimum PLFAs content $\left(0.2 \mu \mathrm{mol} \mathrm{g}{ }^{-1}\right.$ soil) was found at the location with the lowest temperature and productivity $(4190 \mathrm{~m})$. The meta-analysis showed that PLFAs content peaked in mountain forest soils worldwide around $2000 \mathrm{~m}$ independently from biogeographical region. Thus, we conclude that a bell shaped distribution of PLFAs with a peak around $2000 \mathrm{~m}$ a.s.l. may be a general pattern in mountain forest ecosystems. Microbial communities were dominated by Gramnegative bacterial (G-) PLFAs (25-40 \%), which determined the distribution of total PLFAs along the elevation gradient. Contents of Gram-positive $(\mathrm{G}+)$ bacteria decreased with MAP and MAT with elevation. In contrast, fungi and actinomycetes followed a U-shaped distribution, reflecting their adaptation to low precipitation, MAT and low nutritional status of the soils at the highest elevation. Principal component analysis of PLFA distribution along the altitudinal gradient revealed distinct microbial communities for the low (below $3000 \mathrm{~m}$ ) and high elevations (above $3000 \mathrm{~m}$ ). Soil parameters $(\mathrm{C}, \mathrm{N}, \mathrm{pH})$ and climatic variables (MAT, MAP) together explained $44 \%$ of the total variance (partial RDA), whereas soil parameters alone explained $19 \%$ and climatic variables (MAT, MAP) alone explained only $2 \%$. Consequently, we conclude that the effect of climate on the formation of microbial community structure in mountain regions is largely indirect and is mediated through plant productivity and soil properties. 


\section{Introduction}

The structure of microbial communities governs the allocation of carbon $(\mathrm{C})$ in soil and affects ecosystem C cycling (Schimel and Schaeffer, 2012). In turn, chemical soil properties, plant community type, and climatic variables contribute to the development of soil microbial community structure. The major edaphic factors affecting the distribution of microbial communities are soil $\mathrm{pH}$ (Xu et al., 2014) and $\mathrm{C} / \mathrm{N}$ ratios of plant residues and subsequent soil organic matter (SOM). Consequently, acidic $\mathrm{pH}$ and high SOM C/N ratios, promote the development of fungal populations and are less favorable for bacteria (Bossuyt et al., 2001; Xu et al., 2014; Zhang et al., 2013). For example, bacterial populations are suppressed in coniferous forests (Saetre and Baath, 2000), whereas they are stimulated in grassland soils (Djukic et al., 2010). At the same time, the contribution of fungal biomass to microbial communities is higher in forest soils compared to grassland soils (Joergensen and Wichern, 2008). However, at larger scales (continental and global) the effects of plant communities on soil bacterial and fungal diversity weakens (Fierer and Jackson, 2006; Tedersoo et al., 2014), while climatic factors become more important (Tedersoo et al., 2014). Mean annual precipitation (MAP) has a strong positive effect on the richness of fungal communities, and the closer an ecosystem is located to the equator, the richer fungal soil community becomes (Tedersoo et al., 2014). Thus, it is still an open question, which factors control the soil microbial community composition, especially in places with strong climatic variability such as mountain ecosystems.

The elevation gradient of a mountain provides an ideal situation to investigate the response of biogeochemical ecosystem characteristics to climatic variability (i.e. temperature and precipitation) (Wang et al., 2016). MAP and mean annual temperature (MAT) change gradually with altitude, which leads to an expressed ecosystem zonation along the elevation gradient (Hemp, 2006a). Soil properties are also strongly affected by climate along mountain slope

(Seibert et al., 2007; Silver, 1998; Vázquez and Givnish, 1998). Firstly, increasing precipitation accelerates nutrient losses from soil, which decreases $\mathrm{pH}$ and, secondly, the decreasing temperature suppresses decomposition of plant litter and increases the $\mathrm{C} / \mathrm{N}$ ratio of SOM

(Wang et al., 2016; Yoh, 2001). Thus, both factors (plant community change and a shift in soil chemical properties) can alter microbial community structure with elevation. However, it is still unclear, whether these factors have a direct impact or if their effect is mediated by the climatic variables. 
Both, MAP and MAT affect the microbial community structure in soils of mountain climosequences. A negative effect of MAP was shown for the elevation gradient of 540-2360 m located in temperate monsoon climate, whereas a positive effect of MAT was observed (Xu et al., 2014); bacterial diversity was strongly correlated with MAP at the 100-1950 m elevation gradient within a subtropical moist climate (Singh et al., 2014). In contrast, MAP had a rather weak effect in the humid continental climate, whereas the effect of MAT proved to be a greater driver (Zeng et al., 2014). Thus, the climatic zone as well as the length of climosequence transect can affect the MAT or MAP impact on soil microbial community structure. To reveal the impact of both climatic variables, mountain ecosystems allocated in various elevations should be compared.

The presence of natural forests on similar soil parent material of similar age along an elevation gradient allows us to better investigate the factors resulting microbial communities and reveals the dominant factors affecting their composition. The Kilimanjaro mountain climosequence was chosen for this study, because it has i) a broad range of climatic variables due to its extensive elevation gradient (from 767 to $4190 \mathrm{~m}$ ), ii) identical parent material on all sites (volcanic materials), iii) similar time of soil formation, and iv) natural vegetation (represented by forests and alpine heather) with dominance of broadleaf species.

Additional data on the total PLFA content in the forest mountain ecosystems were collected from the literature, to reveal the general effect of elevation, MAP, and MAT on PLFA content. Based on the literature data we hypothesized that i) total PLFA content will be lower at the highest elevation (harsh weather conditions) compared to middle and low elevations, ii) the sites where MAP or MAT are shifted in both directions from optimal conditions will have different microbial community composition compared to plots with optimal conditions.

Based on these hypotheses and previous findings, the objectives of the study were, i) to evaluate the distribution of total microbial biomass (assessed by PLFA analysis) and particular microbial groups along the mountain climosequence, ii) to reveal the effect of climatic (MAT and $\mathrm{MAP})$ and edaphic factors $(\mathrm{C}, \mathrm{N}$ and $\mathrm{pH})$ on the distribution of soil microbial communities, and consequently, iii) to find optimal climatic conditions for development of total soil microbial biomass and microbial groups. 


\section{Materials and methods}

\subsection{Study site}

The study sites were located on the southern slope of Mt. Kilimanjaro ( $\left.3^{\circ} 4^{\prime} 33^{\prime \prime} \mathrm{S}, 37^{\circ} 21^{\prime} 12^{\prime \prime} \mathrm{E}\right)$, Tanzania. Soils of this area are Andosols with folic, histic or umbric topsoil horizons (IUSS Working Group, 2006), and were formed over a similar time span (thousand years, since the last eruption) from volcanic rocks, including trachyte and basalt (Dawson, 1992). The tropical savanna climate is characterized by a bimodal rainfall regime with a long rainy season from March to May and a short rainy season between October and December (Appelhans et al., 2016). The MAP varies between about 750 and $3000 \mathrm{~mm}$ (Hemp, 2006a) depending on elevation, and MAT ranges from 5 to $25{ }^{\circ} \mathrm{C}$ (Figure 3-1).

Six research sites were selected representing natural forests and alpine ecosystems along the elevation gradient from 767 to $4190 \mathrm{~m}$ above sea level (Table 1): 1) Lowland evergreen broadleaf forest (RAU) dominated by Milicia excelsa, Khaya anthotheca, Oxystigmna msoo, Newtonia buchananii and Albizia gummifera, 2) lower montane evergreen forest (FLM) dominated by Macaranga kilimandscharica, Syzygium guineense, Agauria salicifolia and partly by Ocotea usambarensis, 3) montane evergreen Ocotea forest (FOC) dominated by Ocotea usambarensis, Xymalos monospora, Ilex mitis and Cyathea manniana, 4) upper montane evergreen Podocarpus forest (FPO) dominated by Podocarpus latifolius, Schefflera volkensii, Prunus africana and Hagenia abyssinica, 5) subalpine needleleaf Erica forest (FER) dominated by Erica trimera, and 6) alpine Helichrysum cushion vegetation (HEL) dominated by Helichrysum newii, H. citrispinum and H. forskahlii and tussock grasses (Ensslin et al., 2015). A detailed description of the ecosystems is available from Hemp (2006a, 2006b)

\subsection{Soil sampling and analysis}

Soil samples were taken in October 2014. At each site, four independent plots $(5 \times 5 \mathrm{~m})$ were selected. Five top-soil samples $(0-10 \mathrm{~cm}$ depth, without plant litter) per subplot were taken randomly and pooled to reflect ecosystem heterogeneity. The samples were sieved $(2 \mathrm{~mm})$, roots and plant materials were removed. Field samples were separated into two portions: one was dried at room temperature and the other was frozen $\left(-20^{\circ} \mathrm{C}\right)$ until PLFAs analysis. Soil carbon $(\mathrm{C})$ and nitrogen $(\mathrm{N})$ contents were measured using an elemental analyzer (Vario EL II, Germany). Soil pH was measured in water (soil to water ratio is $1: 5$ ). 


\subsection{Extraction of PLFAs}

Extraction of PLFAs from the soil samples was done according to Frostegärd (1991) with modification according to Gunina et al. (2014). Briefly, lipids were extracted by one phase mixture of chloroform, methanol and citric acid (0.15 M, pH 4.0) (ratio 1:2:0.8 (v/v/v)). The 19:0 phospholipid (dinonadecanoylglycerol-phosphatidylcholine) was used as internal standard one and was added to the each soil sample prior to extraction $\left(25 \mu \mathrm{L}, 1 \mu \mathrm{g} \mu \mathrm{L}^{-1}\right)$ (Gunina et al., 2014).

The lipids were separated into neutral-, glyco- and phospholipids on a silica column, and eluting them from the column by chloroform $(5 \mathrm{~mL})$, acetone $(20 \mathrm{~mL})$ and methanol $(20 \mathrm{~mL})$, respectively. Phospholipid fraction was collected, saponified ( $0.3 \mathrm{M}$ solution of $\mathrm{BF}_{3}$ in methanol), PLFAs were methylated (1 $\mathrm{M}$ solution of $\mathrm{NaOH}$ in methanol) and fatty acids methyl esters (FAMEs) were extracted to hexane. The FAMEs were dried under a $\mathrm{N}_{2}$ stream, and redissolved in toluene $(185 \mu \mathrm{L})$ with addition of internal standard two $(15 \mu \mathrm{L}$ of 13:0 fatty acid methyl ester, $1 \mu \mathrm{g}$ $\left.\mu \mathrm{L}^{-1}\right)$.

The PLFAs were measured by GC-MS, with following parameters: a $15 \mathrm{~m} \mathrm{HP}-1$ methylpolysiloxane column connected to a 30 m HP-5 (5\% Phenyl)-methylpolysiloxane column (i.d. $0.25 \mathrm{~mm}$, film thickness of $0.25 \mu \mathrm{m}$ ), rate of the He flow was $2 \mathrm{ml} \mathrm{min}^{-1}$, injection volume was $1 \mu \mathrm{L}$. The temperature program of GC-MS was set up to $80^{\circ} \mathrm{C}$ and then ramped to $164{ }^{\circ} \mathrm{C}$ at $10^{\circ} \mathrm{C}$ $\min ^{-1}$, then to $230{ }^{\circ} \mathrm{C}$ at $0.7^{\circ} \mathrm{C} \min ^{-1}$ and finally to $300{ }^{\circ} \mathrm{C}$ at $10^{\circ} \mathrm{C} \mathrm{min}{ }^{-1}$. Quantity of PLFAs was calculated based on the 29 external standards (Gunina et al., 2014), which were prepared at six concentrations. Final contents of particular PLFAs were presented as molar percentages (mol \%), whereas total content was presented as $\mathrm{nmol} \mathrm{g}^{-1}$ soil. Classification of PLFAs was done according to existing data on their presence in various microorganisms (Leckie, 2005; Lewandowski et al.,

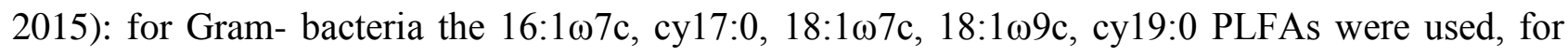
Gram+ i15:0, a15:0, i16:0, i17:0 PLFAs were used, for actinomycetes (Ac) 10Me16:0 and

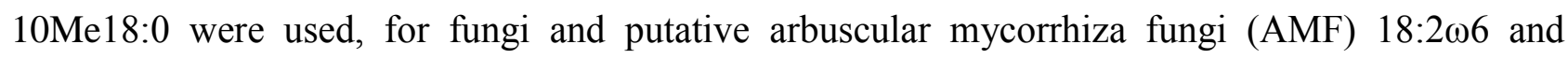
16:1 $\omega 5 \mathrm{c}$ PLFAs were used, respectively.

\subsection{Statistical analysis}

The mol \% of PLFAs were subjected to principal component analysis (PCA) to reveal the major variation pattern. The scores of the first two components from the PCA were used to separate the soils formed at various elevations. 
Redundancy Analysis (RDA) was conducted to evaluate relation between PLFAs and environmental factors in all ecosystems. Explanatory (i.e. environmental) variables were preselected to prevent multicollinearity (variance inflation factor $<10$ ). The RDA results were presented as correlation plot (type 2 scaling). The arrow projection on the $3^{\text {rd }}$ and $4^{\text {th }}$ axes equals the score of environmental variables on the respective RDA axis. Angles between arrows indicate strength of correlation. The coefficient of determination was corrected for the number of variables (adjusted $\mathrm{R}^{2}$ ). Analyses were conducted in R v3.3.1 ( $\mathrm{R}$ core team, 2008) using the "vegan" package for community data analysis. Variance partitioning by partial RDA (pRDA) was conducted to determine partial linear effects of each explanatory matrix in the RDA model (environmental variables: MAT, MAP and soil parameters: $\mathrm{N}, \mathrm{C} / \mathrm{N}$ ratio, $\mathrm{pH}$ ) on the response data (PLFAs) and presented with the equation below.

$R D A=P L F A \approx N+C / N+M A P+M A T+p H$ 


\section{Results}

3.1. Effect of elevation, temperature and precipitation on total PLFAs content in soils of Mt.

\section{Kilimanjaro}

The MAT decreased with elevation, whereas MAP peaked at $2100 \mathrm{~m}$ and decreased afterwards (Fig. 3-1). The total PLFAs followed the trend of MAP distribution, with the maximum at mid elevation $(2100 \mathrm{~m})-2100 \mathrm{nmol} \mathrm{g}^{-1}$ soil (Fig. 3-1).
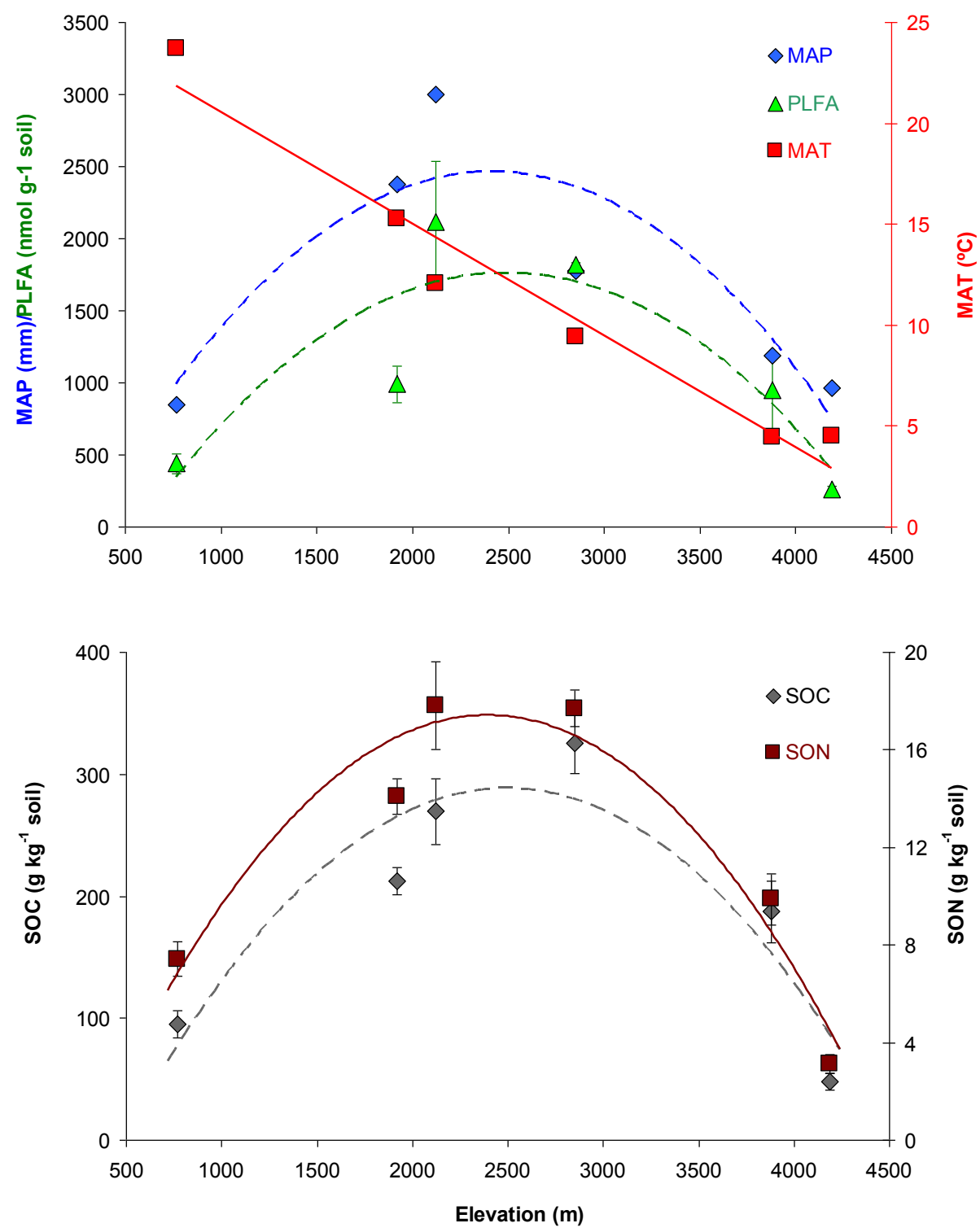

Figure 3-1. Changes of climatic variables - mean annual temperature (MAT) and mean annual precipitation (MAP), soil organic carbon, soil organic nitrogen contents (SOC, SON, respectively) and total PLFAs content within 3500 m elevation gradient on the Mt. Kilimanjaro. 
The G- bacterial PLFAs followed a bell-shaped curve with elevation, whereas actinomycetes, fungi and AMF showed U-shaped curves. The content of $\mathrm{G}+$ bacterial biomarkers decreased with elevation (Fig. 3-2). Thus, microbial groups have a various behavior to elevation change, and, due to the domination of G- bacterial biomarkers in PLFAs composition (25-40\%), this group determined the general PLFAs trend.
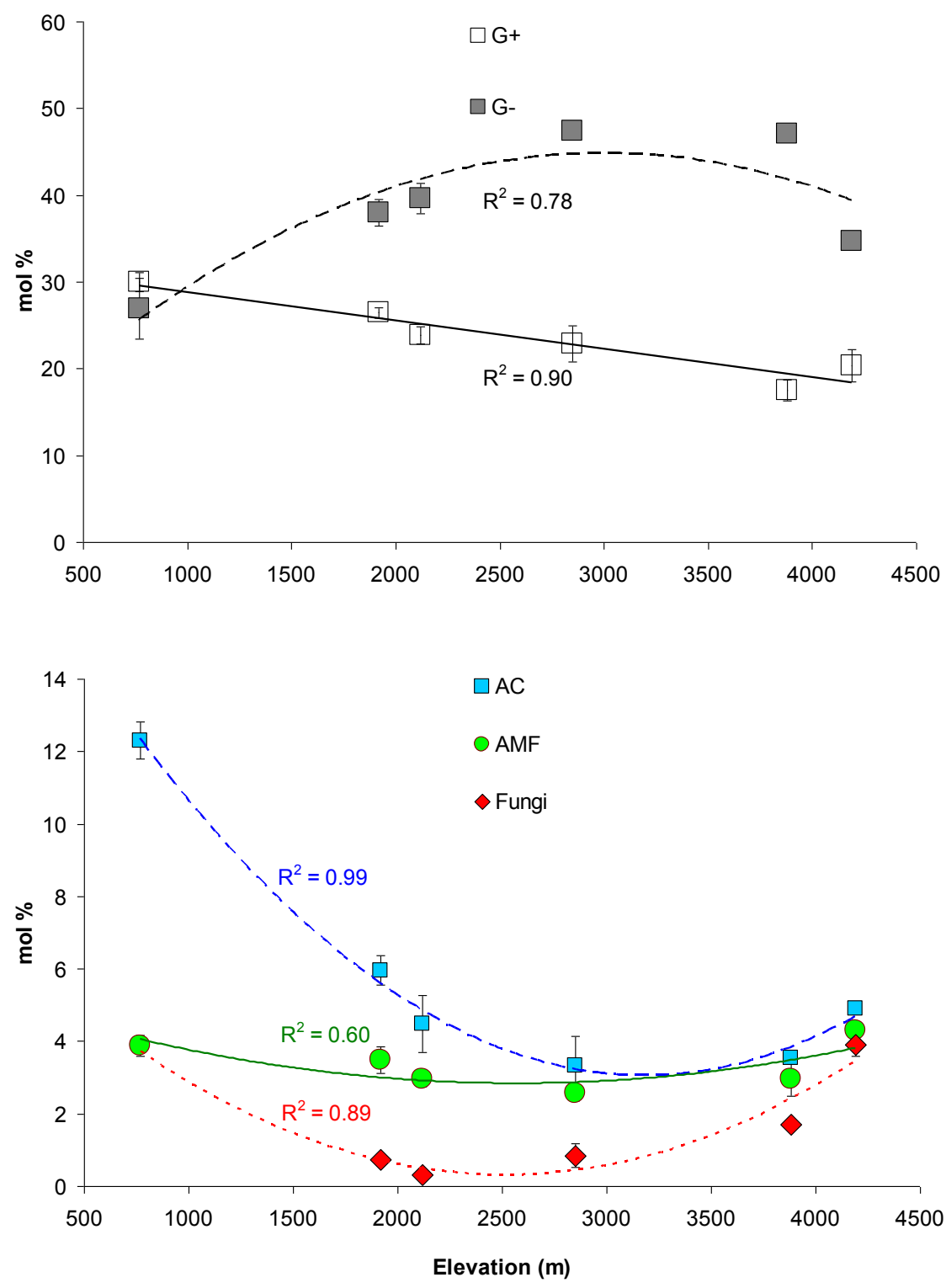

Figure 3-2. Changes of microbial biomarkers portions calculated based on PLFAs analysis (in mol $\%$ ) along a 3500 m elevation gradient at Mt. Kilimanjaro. G+ indicates Gram-positive bacteria, $G$ indicates Gram-negative bacteria, Ac indicates actinomycetes and AMF indicates putative arbuscular mycorrhizal fungi. Data represents means $\pm S E(n=4)$. 
Total PLFAs content decreased with decreasing precipitation, whereas it had bell-shaped relationships with MAT (Supplementary Fig. 3-1). Distinct microbial biomarkers were affected in three ways by MAP decrease: G- bacterial PLFAs decreased, fungal PLFAs increased, and other groups had no significant trends (Supplementary Fig. 3-2). Most of the group specific PLFAs decreased with decreasing MAT, and only G- and fungal biomarker contents increased (Supplementary Fig. 3-2).

\subsection{Effect of soil properties and plant communities on PLFAs content and composition}

Total C and N contents increased with elevation until $2800 \mathrm{~m}$, and decreased thereafter (Table 3-1). Total PLFAs content increased with soil C and N content (Fig. 3-1, bottom), showing quadratic (with $\mathrm{C}$ ) and linear (with $\mathrm{N}$ ) relationships. Increases in soil $\mathrm{C}$ and $\mathrm{N}$ promoted development of Gbacterial PLFAs, whereas other biomarkers decreased (e.g. AM fungi, fungi, actinomycetes) or were unaffected (G+) (Supplementary Fig. 3-3).

Table 3-1. Soil properties of the 3500 m elevation gradient on the Mt. Kilimanjaro.

\begin{tabular}{lccrrrrr}
\hline Ecosystem & Abbreviation & Elevation & MAT, ${ }^{\circ} \mathrm{C}$ & $\mathrm{MAP}, \mathrm{mm}$ & $\mathrm{C}, \mathrm{g} \mathrm{kg}^{-1}$ & $\mathrm{~N}, \mathrm{~g} \mathrm{~kg}^{-1}$ & $\mathrm{pH}$ \\
\hline Lowland dry broadleaf & & & & & & & \\
forest & $\mathrm{RAU}$ & 767 & 23.7 & 845 & $95.2 \pm 11.4$ & $7.4 \pm 0.7$ & $7.5 \pm 0.13$ \\
Lower montane forest & $\mathrm{FLM}$ & 1920 & 15.3 & 2378 & $212.3 \pm 11.3$ & $14.1 \pm 0.7$ & $4.0 \pm 0.08$ \\
Ocotea forest & FOC & 2120 & 12.1 & 2998 & $269.5 \pm 27.2$ & $17.8 \pm 1.8$ & $3.8 \pm 0.06$ \\
Podocarpus forest & FPO & 2850 & 9.4 & 1188 & $325.9 \pm 25.2$ & $17.7 \pm 0.8$ & $3.9 \pm 0.06$ \\
Erica bush forest & FER & 3880 & 4.5 & 1188 & $187.2 \pm 25.2$ & $9.9 \pm 1.1$ & $4.9 \pm 0.09$ \\
Helichrysum cushion & HEL & 4190 & 4.5 & 962 & $47.8 \pm 6.70$ & $3.1 \pm 0.4$ & $5.2 \pm 0.30$ \\
\hline
\end{tabular}

The increase of soil $\mathrm{pH}$ from 4 to 7.5 stimulated fungi and actinomycetes, whereas Gbacterial PLFAs decreased, while both G+ and AM-fungi failed to show consistent trends (Supplementary Fig. 3-4).

The PCA explained $67 \%$ of PLFAs variability. Investigated plots showed a distinct discrimination for microbial community composition (Fig. 3-4): soils below $3000 \mathrm{~m}$ were separated

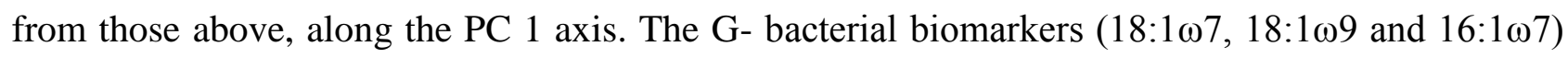
were responsible for separation of soils at low and high elevations. The PC2 separated ecosystems at the highest (HEL) and the lowest elevations (RAU, FLM) from the other sites. 

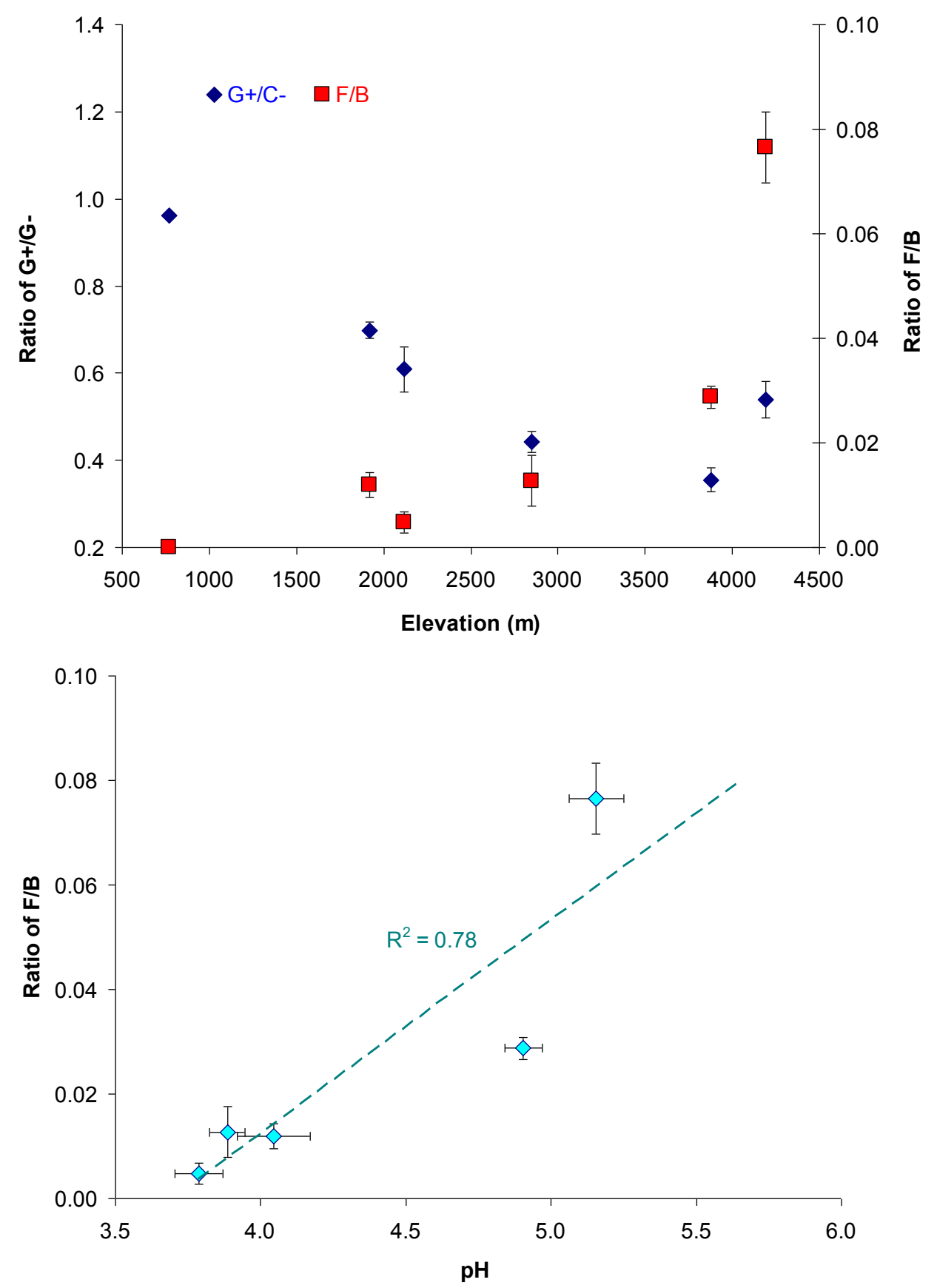

Figure 3-3. Changes of the Gram-positive to Gram-negative ( $G+/ G$-) and fungi to bacteria $(F / B)$ ratios along a 3500 m elevation gradient at Mt. Kilimanjaro (top). Relationship between pH values and fungi to bacteria ratio (bottom). 

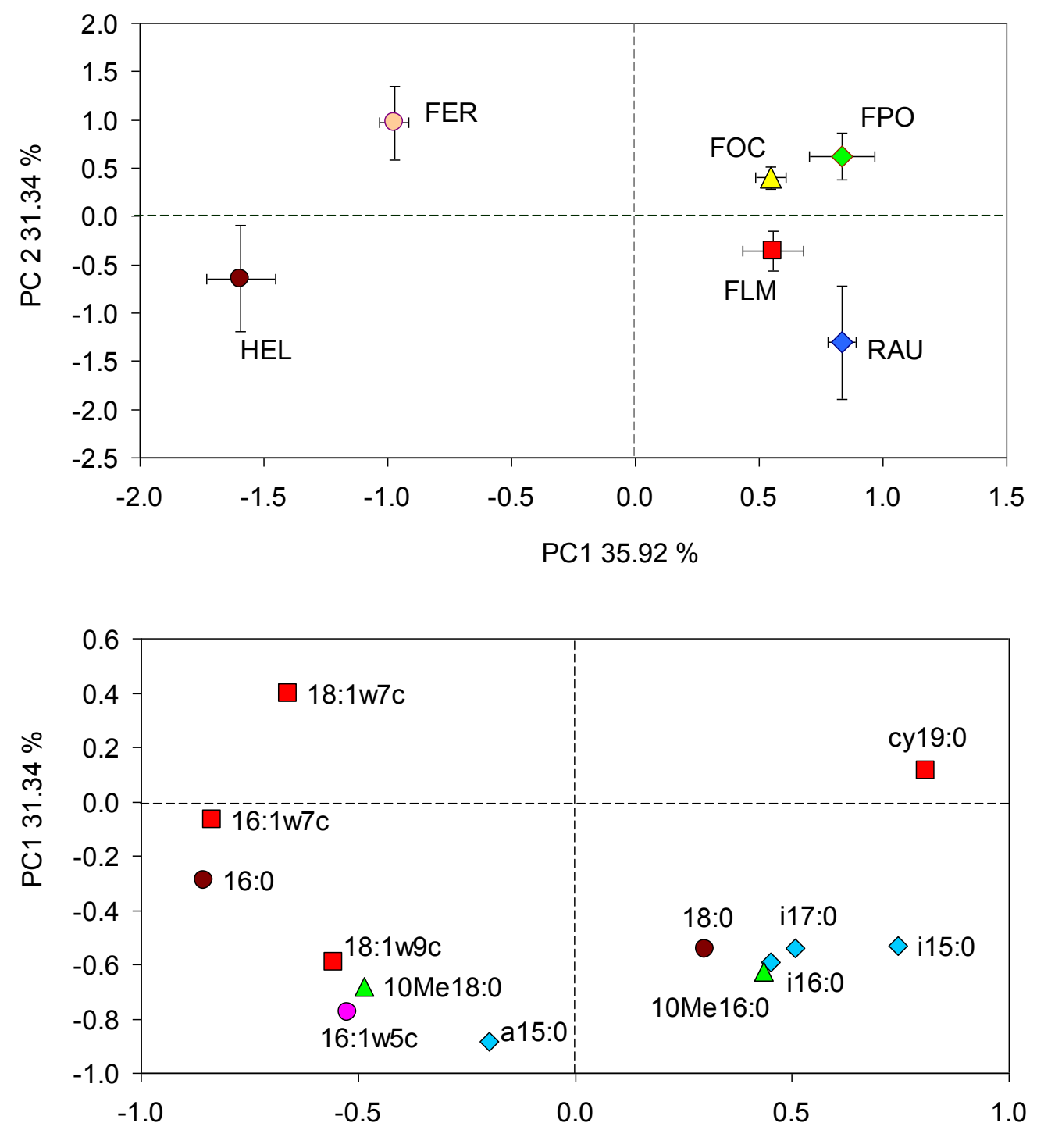

PC2 $35.92 \%$

Figure 3-4. Score plot of PCA presenting the separation of forests along the principal component PC1 and PC2 (top) and loading values for the PLFAs (bottom) for the $3500 \mathrm{~m}$ elevation gradient for Mt. Kilimanjaro. Lowland evergreen broadleaf forest (RAU), lower montane evergreen forest (FLM), montane evergreen Ocotea forest (FOC), upper montane evergreen Podocarpus forest (FPO), subalpine needleleaf Erica forest (FER), alpine Helichrysum cushion vegetation (HEL).

The RDA model was highly significant ( $p$-value $<0.001$ ) and explained $69 \%$ of the variance in the PLFA dataset. RDA axis one (RDA1) and two (RDA2) explained the $79 \%$ and $16 \%$ of the within model variance, respectively (Fig. 3-5 top). Soil $\mathrm{N}$ content was the main factor contributing to RDA1 $(r=-0.78)$, while soil C/N ratio was the strongest related to RDA2 $(r=-0.89)$. 
The $\mathrm{C} / \mathrm{N}$ ratio was negatively correlated with MAT and soil $\mathrm{pH}$. The MAP and soil $\mathrm{N}$ were positively correlated, but unrelated to $\mathrm{C} / \mathrm{N}$ ratio and MAT. Variation in the soil parameters (pRDA) explained $44 \%$ of the total variance in PLFAs (Fig. 3-5 bottom). Climatic variable (MAT, MAP) alone explained $2 \%$. The interaction of soil parameters with climatic variable added another $19 \%$ of the explained variance.
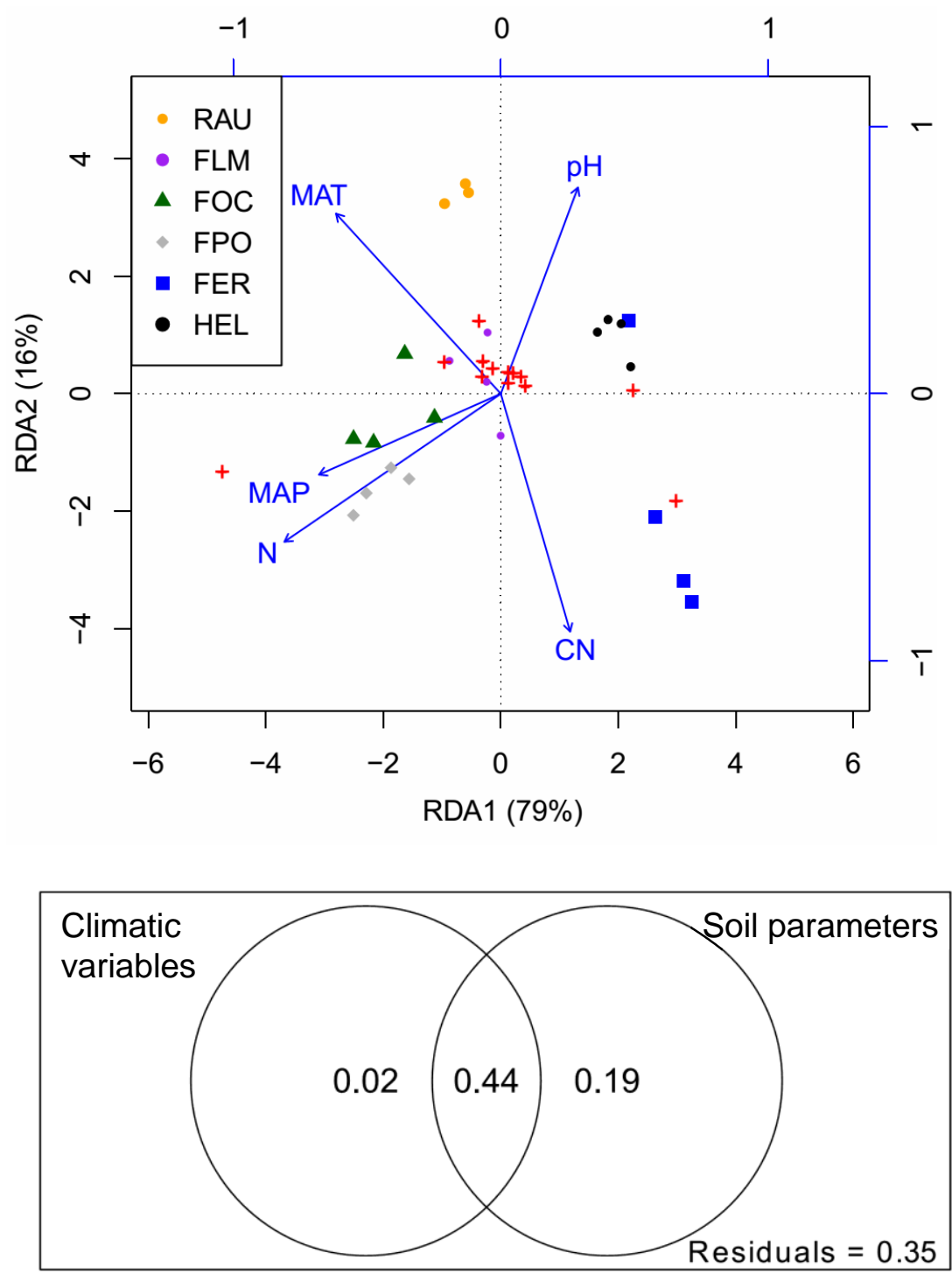

Figure 3-5. Type II scaled Redundancy Analysis (top) of the relation between PLFAs and environmental factors at six Mt. Kilimanjaro ecosystems. The arrow projection on the axis equals the score of environmental variables on the respective RDA axis. Angles between arrows indicate strength of correlation (the smaller the angle, the stronger correlation is). Blue color for the top and right axises are related to environmental variables. Partial Redundancy Analysis (bottom) shows single and combined contribution of climatic and environmental variables for explaining the model variance. 


\section{Discussion}

\subsection{Changes of soil properties with elevation}

The distribution of soil chemical properties (C, N and pH) (Fig. 3-1 bottom, Suppl. Fig. 3-5) along the elevation gradient was in line with previous findings from the experimental sites at Mt. Kilimanjaro (Becker et al., 2015; Ensslin et al., 2015; Pabst et al., 2013, 2016). These changes reflect direct effects of climatic variables on mountain ecosystems. The bell-shaped distribution of soil $\mathrm{C}$ and $\mathrm{N}$ contents are the consequences of decreasing MAT with simultaneous increase of MAP and associated $\mathrm{N}$ inputs. Both climatic variables affect net primary production, and consequently the amount of aboveground and belowground biomass and litter inputs (Becker et al., 2015; Ensslin et al., 2015), and thus, regulate the amount of $\mathrm{C}$ and $\mathrm{N}$ entering the soil (Becker et al., 2016). MAP strongly affected soil $\mathrm{pH}$, which followed the precipitation gradient and decreased with elevation due to the leaching of base cations $\left(\mathrm{Ca}^{2+}, \mathrm{Mg}^{2+}, \mathrm{Na}^{+}, \mathrm{K}^{+}\right)$from the soil profile by high rainfall (Hemp, 2006a).

\subsection{Effect of elevation, temperature and precipitation on total PLFAs}

Total PLFAs content was ten times higher than reported earlier for mineral forest soils (Moore-Kucera and Dick, 2008; Murugan et al., 2014; Myers et al., 2001) and was within the range reported for organic soil horizons (Bååth et al., 1995; Ushioa et al., 2008). Recalculated data (PLFAs content per $\mathrm{g}$ of soil organic $\mathrm{C}$ ) showed values between 3.8-7.5 $\mu \mathrm{mol} \mathrm{PLFAs} \mathrm{g}^{-1} \mathrm{C}$, which are higher than reported for other organic mountain soils $\left(4 \mu \mathrm{mol}\right.$ PLFAs $\left.\mathrm{g}^{-1} \mathrm{C}\right)$ (Djukic et al., 2010). Even at the highest elevations (3800-4200 m), the content of total PLFAs was higher (5-6 $\mu$ mol PLFAs $\mathrm{g}^{-1} \mathrm{C}$ ) than found for comparable sites (1.5-3.5 $\mu$ mol PLFAs g ${ }^{-1} \mathrm{C}$ ) (Xu et al., 2014). These specific differences can be related to the low MAT in these studies (from -2.4 to $+4{ }^{\circ} \mathrm{C}$ ), than in our experimental sites $\left(+9.4\right.$ to $\left.+4.5^{\circ} \mathrm{C}\right)$ (Maestre et al., 2015).

A bell-shaped relationship between total PLFAs content and elevation was found with its maximum at $2100 \mathrm{~m}$ (Fig. 3-1). Such a pattern represents the combination of optimal climatic conditions (MAP and MAT), as well as the highest plant productivity at this elevation. Similar results were found for a 540 - 2360 m elevation sequence in the northeast China mountain forests (Xu et al., 2014). This can be a result of evolving the organisms with different ecological strategies, and thus, their similar contribution to the total biomass with elevation in various mountain ecosystems (Singh et al., 2012). 


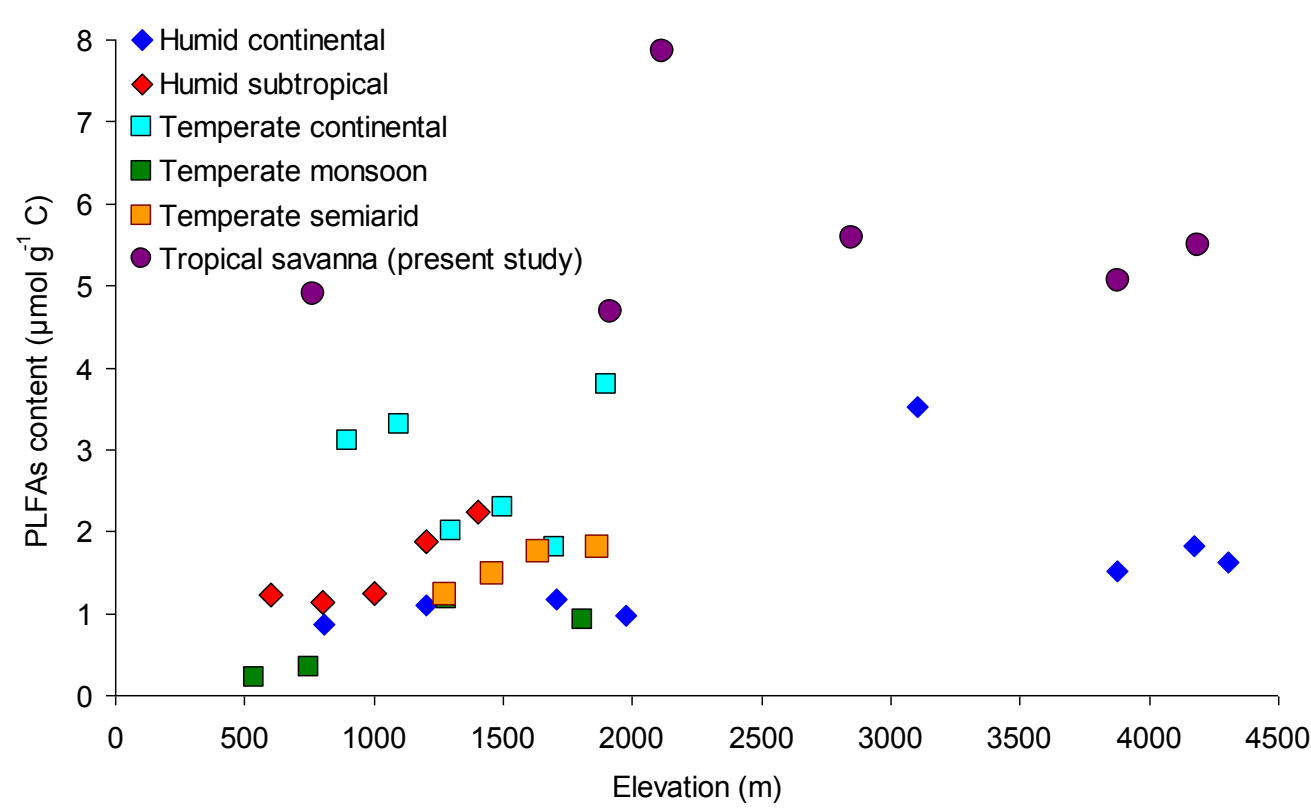

Figure 3-6. Summary of published total PLFAs content in forest soils along mountain elevation gradients in mountain ecosystems of various climatic zones. The data are taken from: humid continental (Zhao 2014; Zhang 2013), temperate monsoon (Xu et al., 2014), humid subtropical (Chang et al., 2016), temperate semiarid (Miao et al., 2013), temperate continental (Djukic et al., 2010), tropical savanna (present study).

To compare the optimum for microbial biomass obtained from our study, we collected literature data on the effects of elevation on the total PLFA contents in mountain forests soils from various biogeographical regions (Fig. 3-6) (Chang et al., 2016; Djukic et al., 2010; Wang et al., 2013; Xu et al., 2014; Zeng et al., 2014; Zhang et al., 2013). This meta-analysis showed that soils located at the same elevation, but in the different climatic zones, vary in total PLFA contents 40fold (between 0.2 and $8 \mu \mathrm{mol}$ PLFAs $\mathrm{g}^{-1} \mathrm{C}$ ): the maximum PLFA content was recorded for tropical savanna climate (present study) and minimum for the temperate monsoon (Xu et al., 2015) and humid continental zones (Xu et al., 2014). However, the maximum PLFAs content was found at around $2000 \mathrm{~m}$ in all regions, which shows that a mid-elevation peak of PLFAs observed in present research can be taken as a general trend.

\subsection{Microbial communities along the elevation gradient of Mt. Kilimanjaro}

PCA analysis distinctly separated high elevation ecosystems (3800 and $4200 \mathrm{~m}$ ) from ones located below $3000 \mathrm{~m}$ (Fig. 3-4). Such separation can be explained by i) climatic factors, namely MAT, which was the lowest for the FER and HEL plots, ii) soil nutritional status - low C and $\mathrm{N}$ 
contents, and iii) low amounts of above ground biomass and associated $\mathrm{C}$ inputs (Ensslin et al., 2015). The G- bacteria, putative arbuscular mycorrhizal fungi (16:1w5) and actinomycetes (10Me18:0) contributed the most to separation of high altitude soils (3800-4200 m) from low altitude ecosystems. Contribution of G- bacteria increased from subalpine $(1700 \mathrm{~m})$ to alpine soils (2400 m), which was related to the tolerance of G- bacteria to freeze-thaw cycles (Margesin et al., 2009). Similar results were obtained in a present study, where freezing occurs on a daily basis at the highest elevation (Gütlein et al., 2017; Hemp, 2006a). The G- PLFAs peaked at the $3000 \mathrm{~m}$ elevation, which agrees with increase of bacterial richness at mid-elevation reported by Singh et al. (2012) and a shift in bacterial community composition from G+ to G- (Margesin et al., 2009). Decrease of G- bacteria at the highest elevation is a consequence of open vegetation cover within the Helichrysum scrub (4200 m), and, thus, the low amount of easily available root exudates (Gütlein et al., 2017), which are the preferred C source for this microbial group (Gunina et al., 2014).

In contrast, $\mathrm{G}+$ bacterial groups contributed the most to microbial communities at the low elevations (below $767 \mathrm{~m}$ ), but their content decreased along the climosequence. A similar trend for G+ bacteria was reported for alpine soils (Margesin et al., 2009), and is related to low tolerance of this group to harsh weather conditions (i.e. low temperature and a daily freeze-thaw cycles common for HEL and partly for FER ecosystems) (Supplementary figure 3-2). The G+/G- ratio, characterizing starvation stress for microorganisms (Hammesfahr et al., 2008), decreased with elevation (Fig. 3-3). The decrease of starvation stress is explained by an increase of SOC content, creating better conditions for functioning of $\mathrm{G}$ - bacteria compared to $\mathrm{G}+$. In contrast, the highest stress found at RAU (760 m) ecosystem was due to its low SOC content, which favors development of $\mathrm{G}+$ bacteria.

Reported increases of fungal abundance with elevation (Fig. 3-2) can be attributed to three reasons: 1) decrease of litter decomposability and increase of its $\mathrm{C} / \mathrm{N}$ ratio, which facilitates fungal development, 2) general adaptation of fungi to low soil $\mathrm{N}$ supply, 3) and adaptation to harsh (dry and cold) environmental conditions, which include decrease MAT and MAP along the climosequence (Ma et al., 2015; Schinner and Gstraunthaler, 1981; Xu et al., 2015; Zhang et al., 2013).

The RDA analysis (Fig. 3-5) was consistent with the trends of distinct microbial biomarker distribution and showed that climatic variables affected PLFAs composition in two opposite directions, with temperature being more important. Soil chemistry controls PLFAs composition in 
three directions: total $\mathrm{N}, \mathrm{C} / \mathrm{N}$ ratio and inversely to both soil acidity. The pRDA analysis showed that climatic factors indirectly affect the PLFAs through changes in vegetation and soil parameters.

\section{Conclusions}

Development of natural forests on similar parent material and along the same elevation gradient facilitates investigation of the effects of climatic variables on the formation of soil microbial communities. The study of soil microbial community structure in natural ecosystems of Mt. Kilimanjaro (from 770 until $4200 \mathrm{~m}$ ), revealed a bell-shaped curve of total biomarkers (PLFAs) contents with elevation, with a maximum at $2100 \mathrm{~m}$. A literature review revealed that both, MAP and MAT affect PLFAs content not only in Mt. Kilimanjaro ecosystems, but also in other mountain ecosystems around the world. Overall, it appears that total PLFA content peaks at the mid-elevation ( $2000 \mathrm{~m}$ ) across a broad range of ecosystems around the world.

Soil microbial communities at the highest elevation ecosystems (above $3000 \mathrm{~m}$ ) were distinctly different from those at lower elevations (below $3000 \mathrm{~m}$ ). Gram-negative bacteria dominated the microbial community in Mt. Kilimanjaro soils, accounting for $25-40 \%$, and, thus, regulating the major trend of PLFAs distribution with elevation. With increasing elevation, Grampositive bacteria were replaced by fungi as a reaction to the harsh environmental conditions in the alpine zone above $4000 \mathrm{~m}$ (low MAT, and soil C and N contents). These variations were indirectly depending on climatic factors, and mainly explained by changes in vegetation composition and soil parameters. We conclude that the optimal conditions for microbial biomass in mountain soils are common at elevations between 1700 and $2700 \mathrm{~m}$, mainly because optimal combination of climatic conditions for vegetation and soil development. 


\section{Acknowledgements}

We thank the Tanzanian Commission for Science and Technology (COSTECH), the Tanzania Wildlife Research Institute (TAWIRI), the Forestry and Beekeeping Division of the Tanzania Ministry of Natural Resources and Tourism (MNRT) and the Mount Kilimanjaro National Park (KINAPA) for permitting our research at Mt. Kilimanjaro. This study was supported by grants from the German Research Foundation (DFG) within Project KU 1184/20-2 and /20-3 of the ResearchUnit 1246 (Kilimanjaro Ecosystems under Global Change) and the DFG Major Research Instrumentation Programme (INST 186/1006-1). This study was supported by a grant from the Erasmus Mundus Joint Doctoral Programme "Forest and Nature for Society" (FONASO) awarded to A. Gunina.

\section{References}

Appelhans, T., Mwangomo, E., Otte, I., Detsch, F., Nauss, T., Hemp, A., 2016. Eco-meteorological characteristics of the southern slopes of Kilimanjaro, Tanzania. Int. J. Climatol. 36, 32453258. doi:10.1002/joc. 4552

Bååth, E., Frostegård, Å., Pennanen, T., Fritze, H., 1995. Microbial community structure and pH response in relation to soil organic matter quality in wood-ash fertilized, clear-cut or burned coniferous forest soils. Soil Biol. Biochem. 27, 229-240. doi:10.1016/0038-0717(94)00140$\mathrm{V}$

Becker, J., Pabst, H., Mnyonga, J., Kuzyakov, Y., 2015. Annual litterfall dynamics and nutrient deposition depending on elevation and land use at Mt. Kilimanjaro. Biogeosciences 12, 5635-5646. doi:10.5194/bg-12-5635-2015

Becker, J.N., Gütlein, A., Cornejo, N.S., Kiese, R., Hertel, D., Kuzyakov, Y., 2016. Legume and Non-legume Trees Increase Soil Carbon Sequestration in Savanna. Ecosystems 1-11. doi:10.1007/s10021-016-0087-7

Bossuyt, H., Denef, K., Six, J., Frey, S.D., Merckx, R., Paustian, K., 2001. Influence of microbial populations and residue quality on aggregate stability. Appl. Soil Ecol. 16, 195-208. doi:10.1016/S0929-1393(00)00116-5

Chang, E.-H., Chen, T.-H., Tian, G., Chiu, C.-Y., 2016. The effect of altitudinal gradient on soil microbial community activity and structure in moso bamboo plantations. Appl. Soil Ecol. 98, 213-220. doi:10.1016/j.apsoil.2015.10.018

Dawson, J.B., 1992. Neogene tectonics and volcanicity in the North Tanzania sector of the Gregory Rift Valley: contrasts with the Kenya sector. Tectonophysics 204, 81-92. doi:10.1016/00401951(92)90271-7

Djukic, I., Zehetner, F., Mentler, A., Gerzabek, M.H., 2010. Microbial community composition and activity in different Alpine vegetation zones. Soil Biol. Biochem. 42, 155-161.

Ensslin, A., Rutten, G., Pommer, U., Zimmermann, R., Hemp, A., Fischer, M., 2015. Effects of elevation and land use on the biomass of trees, shrubs and herbs at Mount Kilimanjaro. Ecosphere 6, 1-15. doi:10.1890/ES14-00492.1

Fierer, N., Jackson, R.B., 2006. The diversity and biogeography of soil bacterial communities. Proc. Natl. Acad. Sci. U. S. A. 103, 626-631. doi:10.1073/pnas.0507535103 
Frostegard, A., Tunlid, A., Baath, E., 1991. Microbial biomass measured as total lipid phosphate in soils of different organic content. J. Microbiol. Methods 14, 151-163. doi:10.1016/01677012(91)90018-1

Gunina, A., Dippold, M., Glaser, B., Kuzyakov, Y., 2014. Fate of low molecular weight organic substances in an arable soil. Soil Biol. Biochem. 77, 304-313.

Gütlein, A., Zistl-Schlingmann, M., Becker, J.N., Cornejo, N.S., Detsch, F., Dannenmann, M., Appelhans, T., Hertel, D., Kuzyakov, Y., Kiese, R., 2017. Nitrogen turnover and greenhouse gas emissions in a tropical alpine ecosystem, Mt. Kilimanjaro, Tanzania. Plant Soil 411, 243-259. doi:10.1007/s11104-016-3029-4

Hammesfahr, U., Heuer, H., Manzke, B., Smalla, K., Thiele-Bruhn, S., 2008. Impact of the antibiotic sulfadiazine and pig manure on the microbial community structure in agricultural soils. Soil Biol. Biochem. 40, 1583-1591. doi:10.1016/j.soilbio.2008.01.010

Hemp, A., 2006a. Continuum or zonation? Altitudinal gradients in the forest vegetation of Mt. Kilimanjaro. Plant Ecol. 184, 27-42. doi:10.1007/s11258-005-9049-4

Hemp, A., 2006b. Vegetation of Kilimanjaro: hidden endemics and missing bamboo. Afr. J. Ecol. 44, 305-328. doi:10.1111/j.1365-2028.2006.00679.x

IUSS Working Group, 2006. World reference base for soil resources.

Joergensen, R.G., Wichern, F., 2008. Quantitative assessment of the fungal contribution to microbial tissue in soil. Soil Biol. Biochem. 40, 2977-2991. doi:10.1016/j.soilbio.2008.08.017

Leckie, S.E., 2005. Methods of microbial community profiling and their application to forest soils. For. Ecol. Manag. 220, 88-106.

Lewandowski, T.E., Forrester, J.A., Mladenoff, D.J., Stoffel, J.L., Gower, S.T., D’Amato, A.W., Balser, T.C., 2015. Soil microbial community response and recovery following group selection harvest. For. Ecol. Manag. 340, 82-94.

Ma, L., Guo, C., Lü, X., Yuan, S., Wang, R., 2015. Soil moisture and land use are major determinants of soil microbial community composition and biomass at a regional scale in northeastern China. Biogeosciences 12, 2585-2596. doi:10.5194/bg-12-2585-2015

Maestre, F.T., Delgado-Baquerizo, M., Jeffries, T.C., Eldridge, D.J., Ochoa, V., Gozalo, B., Quero, J.L., García-Gómez, M., Gallardo, A., Ulrich, W., Bowker, M.A., Arredondo, T., BarrazaZepeda, C., Bran, D., Florentino, A., Gaitán, J., Gutiérrez, J.R., Huber-Sannwald, E., Jankju, M., Mau, R.L., Miriti, M., Naseri, K., Ospina, A., Stavi, I., Wang, D., Woods, N.N., Yuan, X., Zaady, E., Singh, B.K., 2015. Increasing aridity reduces soil microbial diversity and abundance in global drylands. Proc. Natl. Acad. Sci. 112, 15684-15689. doi:10.1073/pnas.1516684112

Margesin, R., Jud, M., Tscherko, D., Schinner, F., 2009. Microbial communities and activities in alpine and subalpine soils. FEMS Microbiol. Ecol. 67, 208-218. doi:10.1111/j.15746941.2008.00620.x

Moore-Kucera, J., Dick, R.P., 2008. PLFA profiling of microbial community structure and seasonal shifts in soils of a Douglas-fir chronosequence. Microb Ecol 55, 500-511.

Murugan, R., Beggi, F., Kumar, S., 2014. Belowground carbon allocation by trees, understory vegetation and soil type alter microbial community composition and nutrient cycling in tropical Eucalyptus plantations. Soil Biol. Biochem. 76, 257-267. doi:10.1016/j.soilbio.2014.05.022

Myers, R.T., Zak, D.R., White, D.C., Peacock, A., 2001. Landscape-Level Patterns of Microbial Community Composition and Substrate Use in Upland Forest Ecosystems. Soil Sci. Soc. Am. J. 65, 359-367. doi:10.2136/sssaj2001.652359x 
Pabst, H., Gerschlauer, F., Kiese, R., Kuzyakov, Y., 2016. Land Use and Precipitation Affect Organic and Microbial Carbon Stocks and the Specific Metabolic Quotient in Soils of Eleven Ecosystems of Mt. Kilimanjaro, Tanzania. Land Degrad. Dev. 27, 592-602. doi:10.1002/ldr.2406

Pabst, H., Kühnel, A., Kuzyakov, Y., 2013. Effect of land-use and elevation on microbial biomass and water extractable carbon in soils of Mt. Kilimanjaro ecosystems. Appl. Soil Ecol. 67, $10-19$.

Saetre, P., Baath, E., 2000. Spatial variation and patterns of soil microbial community structure in a mixed spruce \pm birch stand. Soil Biol. Biochem. 909-917.

Schimel, J., Schaeffer, S.M., 2012. Microbial control over carbon cycling in soil. Front. Microbiol. 3. doi:10.3389/fmicb.2012.00348

Schinner, F., Gstraunthaler, G., 1981. Adaptation of Microbial Activities to the Environmental Conditions in Alpine Soils. Oecologia 50, 113-116.

Seibert, J., Stendahl, J., Sørensen, R., 2007. Topographical influences on soil properties in boreal forests. Geoderma 141, 139-148. doi:10.1016/j.geoderma.2007.05.013

Silver, W., 1998. The Potential Effects of Elevated $\mathrm{Co}_{2}$ and Climate Change on Tropical Forest Soils and Biogeochemical Cycling. Clim. Change 39, 337-361. doi:10.1023/a:1005396714941

Singh, D., Lee-Cruz, L., Kim, W.-S., Kerfahi, D., Chun, J.-H., Adams, J.M., 2014. Strong elevational trends in soil bacterial community composition on Mt. Halla, South Korea. Soil Biol. Biochem. 68, 140-149. doi:10.1016/j.soilbio.2013.09.027

Singh, D., Takahashi, K., Kim, M., Chun, J., Adams, J.M., 2012. A hump-backed trend in bacterial diversity with elevation on Mount Fuji, Japan. Microb. Ecol. 63, 429-437. doi:10.1007/s00248-011-9900-1

Tedersoo, L., Bahram, M., Põlme, S., Kõljalg, U., Yorou, N.S., Wijesundera, R., Villarreal Ruiz, L., Vasco-Palacios, A.M., Thu, P.Q., Suija, A., Smith, M.E., Sharp, C., Saluveer, E., Saitta, A., Rosas, M., Riit, T., Ratkowsky, D., Pritsch, K., Põldmaa, K., Piepenbring, M., Phosri, C., Peterson, M., Parts, K., Pärtel, K., Otsing, E., Nouhra, E., Njouonkou, A.L., Nilsson, R.H., Morgado, L.N., Mayor, J., May, T.W., Majuakim, L., Lodge, D.J., Lee, S.S., Larsson, K.-H., Kohout, P., Hosaka, K., Hiiesalu, I., Henkel, T.W., Harend, H., Guo, L., Greslebin, A., Grelet, G., Geml, J., Gates, G., Dunstan, W., Dunk, C., Drenkhan, R., Dearnaley, J., De Kesel, A., Dang, T., Chen, X., Buegger, F., Brearley, F.Q., Bonito, G., Anslan, S., Abell, S., Abarenkov, K., 2014. Fungal biogeography. Global diversity and geography of soil fungi. Science 346, 1256688. doi:10.1126/science. 1256688

Ushioa, M., Wagai, R., Balser, T.C., Kitayama, K., 2008. Variations in the soil microbial community composition of a tropical montane forest ecosystem. Soil Biol. Biochem. 40, 2699-2702.

Vázquez, A.J., Givnish, T.J., 1998. Altitudinal gradients in tropical forest composition, structure, and diversity in the Sierra de Manantlán. J. Ecol. 86, 999-1020. doi:10.1046/j.13652745.1998.00325.x

Wang, D., He, N., Wang, Qing, Lü, Y., Wang, Qiufeng, Xu, Z., Zhu, J., 2016. Effects of Temperature and Moisture on Soil Organic Matter Decomposition Along Elevation Gradients on the Changbai Mountains, Northeast China. Pedosphere 26, 399-407. doi:10.1016/S1002-0160(15)60052-2

Wang, M., Qu, L., Ma, K., Yuan, X., 2013. Soil microbial properties under different vegetation types on Mountain Han. Sci. China Life Sci. 56, 561-570. doi:10.1007/s11427-013-4486-0 
Xu, M., Li, Xiaoliang, Cai, X., Gai, J., Li, Xiaolin, Christie, P., Zhang, J., 2014. Soil microbial community structure and activity along a montane elevational gradient on the Tibetan Plateau. Eur. J. Soil Biol. 64, 6-14. doi:10.1016/j.ejsobi.2014.06.002

Xu, Z., Yu, G., Zhang, X., Ge, J., He, N., Wang, Q., Wang, D., 2015. The variations in soil microbial communities, enzyme activities and their relationships with soil organic matter decomposition along the northern slope of Changbai Mountain. Appl. Soil Ecol. 86, 19-29. doi:10.1016/j.apsoil.2014.09.015

Yoh, M., 2001. Soil C/N Ratio as Affected by Climate: An Ecological Factor of Forest NO3Leaching. Water. Air. Soil Pollut. 130, 661-666. doi:10.1023/A:1013860830153

Zeng, X., Zhang, W., Cao, J., Liu, X., Shen, H., Zhao, X., 2014. Changes in soil organic carbon, nitrogen, phosphorus, and bulk density after afforestation of the"Beijing-Tianjin Sandstorm Source Control" programinChina. Catena 118, 186-194.

Zhang, B., Liang, C., He, H., Zhang, X., 2013. Variations in Soil Microbial Communities and Residues Along an Altitude Gradient on the Northern Slope of Changbai Mountain, China. PLOS ONE 8, e66184. doi:10.1371/journal.pone.0066184 


\section{Chapter 4 Article II Response of soil microbial community to afforestation with pure and mixed species}

Anna Gunina ${ }^{\mathrm{a}, \mathrm{b}}$, Andrew R. Smith ${ }^{\mathrm{a}}$, Douglas L. Godbold ${ }^{\mathrm{c}}$, Davey L. Jones ${ }^{\mathrm{a}}$ and Yakov Kuzyakov ${ }^{\mathrm{b}, \mathrm{d}}$

${ }^{a}$ School of Environment, Natural Resources and Geography, Bangor University, Bangor, Gwynedd, LL57 2UW, UK;

${ }^{\mathrm{b}}$ Department of Agricultural Soil Science, Georg August University of Göttingen, Göttingen, 37077, Germany;

${ }^{\mathrm{c}}$ Institute for Forest Ecology, Universität für Bodenkultur, BOKU, Peter-Jordan-Straße 82, 1190 Vienna, Austria;

${ }^{\mathrm{d}}$ Department of Soil Science of Temperate Ecosystems, Georg August University of Göttingen, Göttingen, 37077, Germany

Plant and Soil, 2017, Volume 412, Issue 1-2, pp 357-368.

Author contributions: Anna Gunina prepared the manuscript. All other authors contributed to the final version of manuscript.

Keywords: woodland, plant microbial interactions, microbial biomarkers, land use change, forest composition, ammonium and nitrate, soil solution, tree identity. 


\begin{abstract}
Objectives

Afforestation changes soil chemical properties over several decades. In contrast, microbial community structure can be shifted within the first decade and so, the direct effects of tree species can be revealed. The aim of this study was to determine the alteration of soil microbial community composition 10 years after afforestation by trees with contrasting functional traits.
\end{abstract}

Methods

The study was conducted at the BangorDIVERSE temperate forest experiment. Soil samples were collected under single, two and three species mixtures of alder and birch, beech and oak - early and secondary successional species, respectively, and contiguous agricultural field. Soil was analysed for total carbon $(\mathrm{C})$ and nitrogen $(\mathrm{N})$ contents, and microbial community structure (phospholipid fatty acids (PLFAs) analysis).

\title{
Results and conclusions
}

The total PLFAs content (370-640 $\mathrm{nmol} \mathrm{g}^{-1}$ soil) in forest plots increased for 30 to $110 \%$ compared to the agricultural soil $\left(290 \mathrm{nmol} \mathrm{g}^{-1}\right.$ soil). In contrast, soil $\mathrm{C}, \mathrm{N}$ and $\mathrm{C} / \mathrm{N}$ ratios were altered over 10 years much less - increased only up to $20 \%$ or even decreased (for beech forest).

Afforestation increased bacterial PLFAs by 20-120\%, whereas it had stronger impact on the development of fungal communities (increased by 50-200\%). These effects were proved for all forests, but were more pronounced under the monocultures compared to mixtures. This indicates that species identity has a stronger effect than species diversity. Principal component analysis of PLFAs revealed that under mono and three species mixtures similar microbial communities were formed. In contrast, gram-positive PLFAs and actinomycete PLFAs contributed mainly to differentiation of two species mixtures from other forests. Thus, at the early afforestation stage: i) soil biological properties are altered more than chemical, and ii) tree species identity affects more than species amount on both processes. 


\section{Introduction}

Forests in the European Union cover more than 180 million ha representing $41 \%$ of the total land area. In response to a range of European policies (e.g. EU Biodiversity Strategy, EU Forest Strategy) afforestation area has increased by 17 million ha in the last 25 years and this trend is expected to continue for the foreseeable future (EEA, 2015). Both pure and mixed species forests are used for afforestation of former arable and grassland soils, however, there is still a lack of information on the effects of various tree species on maximising soil function (e.g. enhancing carbon (C) and nitrogen (N) storage, promoting nutrient cycling and water storage), and especially on the changes in soil microbial communities. This fundamental knowledge would be useful to make informed management decisions to maximise both above and below-ground diversity and to promote sustainable landscape functioning.

Forest soil properties are altered by the processes of tree establishment, growth and mortality. Soil $\mathrm{C}$ and $\mathrm{N}$ stocks generally increase with forest age and achieve their maximum accumulation rates during the exponential tree growth phase (DeLuca and Boisvenue 2012), and gradually decline in late successional forest stages. Approximately 30-50 years after afforestation, soil C and N stocks begin to stabilize (Fu et al. 2015; Kalinina et al. 2011). The quality of leaf litter also changes with forest age (e.g. decrease in leaf nutrient content, increased in $\mathrm{C} / \mathrm{N}$ and lignin/N ratios), which directly affects litter decomposition and soil nutrient supply (Trap et al. 2013). A well-known effect of afforestation is soil acidification (Berthrong et al. 2009) due to changes in soil base saturation, litter chemistry, rhizodeposition and absence of liming ( $\mathrm{Fu}$ et al. 2015). The reported $\mathrm{pH}$ decrease for 27 year-old broadleaf forests was around 0.95 units (Fu et al. 2015), while it is estimated that between 80-100 years of forest development is required to obtain $\mathrm{pH}$ values close to those found in native forests (Ritter et al. 2003). Overall, this suggests that soil acidity and $\mathrm{C}$ and $\mathrm{N}$ stocks change very slowly during afforestation.

Concurrent with changes in soil chemistry, the biomass, quality composition and diversity of soil microbial communities can also be expected to shift following trees establishment (Grayston et al. 1997b; Macdonald et al. 2009). Afforestation induce a rapid increase in microbial biomass with changes apparent within one year of tree planting (van der Wal et al. 2006). Afforestation typically stimulates the development of fungal communities (Jangid et al. 2011; Buckley and Schmidt 2003), whereas bacteria appear to be less sensitive to land use changes (Klein et al. 1995). In addition, the diversity and relative abundance of individual fungal and bacterial species have been shown to increase after afforestation. For example, Acidobacteria appeared to dominate under birch while 
Firmicutes and Proteobacteria were more dominant under young pine forests (Nazaries et al. 2015). Thus, microbial communities might serve as a primary indicator of ecosystems recovery as their changes occur more rapidly than for soil chemical properties.

Forests affect the composition of microbial communities not only directly ( $\mathrm{Fu}$ et al. 2015), but also indirectly through changes in soil chemical and physical properties (Yannikos et al. 2014; Mann and Tolbert 2000) depending on the forest type, biodiversity, and land use history (Yannikos et al. 2014). The time range needed for microbial communities to evolve to those typical of native forests is estimated to be 30 - 50 years (Jangid et al. 2011; Buckley and Schmidt 2003; van der Wal et al. 2006) and is affected by the rate at which soil properties change (van der Wal et al. 2006). Generally, the composition of microbial communities formed under broadleaf forests is radically different from those formed under coniferous species ( $\mathrm{Li}$ et al.; Cong et al. 2015). These differences can be ascribed mainly due to variations in leaf litter chemistry, changes in mycorrhizal communities and colonization. Comparison of soils formed under broadleaf forest has also revealed that tree species like beech promote development of microbial communities different from those developed under ash, lime and hornbeam forests, mainly due to low $\mathrm{C} / \mathrm{N}$ ratio of beech litter, presence of microbial activity inhibitors in root exudates and more rapid decreases in soil $\mathrm{pH}$ (Scheibe et al. 2015). Composition of forest was also reported to affect microbial community structure, which was found for the beech grown in mono- and mixed forests (Thoms and Gleixner 2013). However, in addition to forest community composition, variations in functional traits of trees should be accounted for due to their strong potential effects on the formation and shaping of soil microbial communities (Fu et al. 2015). Thus, due to a variety of complex interacting factors, it is difficult to disentangle the direct effects of forest tree community composition from the effect of soil properties on microbial community dynamics, especially under mature forests, where soil chemical properties may have already been changed. Further, it is difficult to distinguish between tree identity and forest tree community composition effects, because functional traits of single tree species can be masked or reduced in forest mixtures. Thus, only in experiments where both single species and mixtures of trees are studied simultaneously in the early afforestation stage can conclusions about the effect of tree identity and forest composition on the formation of soil microbial communities be made.

The objective of this study was to evaluate the effects of forest tree community composition on soil microbial community structure at the early forest development stage (10 years after afforestation). It was hypothesized that independent of forest type, i) microbial community structure 
will change more strongly than soil physico-chemical properties and ii) fungal biomass will increase faster than bacterial biomass; iii) monoculture forests will promote strong and more specific changes in content of particular microbial groups, whereas in species mixtures these responses will be dampened.

\section{Materials and methods}

\subsection{Study site and soil sampling}

Soils were obtained from the BangorDIVERSE forest experiment located at the Henfaes Research Centre, North Wales, UK $\left(53^{\circ} 14^{\prime} \mathrm{N}, 4^{\circ} 01^{\prime} \mathrm{W}\right)$. Climate was characterized as hyperoceanic, with mean annual precipitation of $1034 \mathrm{~mm}$ and mean annual temperature of $11.5^{\circ} \mathrm{C}$ (Campbell Scientific Ltd, Shepshed, UK). The site was set up in 2004 with a total area of 2.36 ha. Soils are classified as Eutric Fluvic Cambisols (WRB 2006) (Fluventic Dystrochrept, USDA system) and have fine loamy texture (Smith A. et al. 2013). Each type of forests, namely: single species or two and three species mixtures of European alder (Alnus glutinosa L.), Silver birch (Betula pendula Roth), European beech (Fagus sylvatica, L.), and English oak (Quercus robur L.) were planted in four independent field replication, with a size replications were: 62, 121 and $196 \mathrm{~m}^{2}$ for the single, two and three species forests, respectively. Forests were formed by tree species with contrasting functional traits: early primary and late successional stages species, N-fixing and non N-fixing, producing low and high litter quality. Monoculture species plots of alder, birch, beech and oak, two species mixtures of alder+beech, alder+oak, birch+beech, birch+oak, three species mixtures of alder+birch+beech, alder+birch+oak were used for the present experiment. The understory was formed mainly by grass, goose grass, nettle, bramble and dock. Only the plots taken for that study are mentioned, and for a full description of the experimental design see Ahmed et al. (2016). The main properties of the plant communities are presented in Table 4-1. Contiguous agricultural field (established before the BangorDIVERSE experiment), was chosen as a comparative soil due to its same historical land use and soil type. The latest cultivation species at the agricultural field was oilseed rape (Brassica napus) had been cultivated there following the addition of $\mathrm{K}_{2} \mathrm{O}\left(20 \mathrm{~kg} \mathrm{ha}^{-1}\right)$ and $\mathrm{N}\left(60 \mathrm{~kg} \mathrm{ha}^{-1}\right)$. Soil samples were collected from the top 0-10 $\mathrm{cm}$ depth (without soil litter) from each field replication, and each sample was consisted of three independent soil cores. Each sample was divided into three parts: one was stored at $5{ }^{\circ} \mathrm{C}$ and used for extraction of soil solution, the second was dried at $105{ }^{\circ} \mathrm{C}$ and used for total $\mathrm{C}$ and $\mathrm{N}$ analysis (Supplementary Table 4-2), and the third was stored at $-20{ }^{\circ} \mathrm{C}$ and used for phospholipid fatty acid (PLFA) analysis. 


\subsection{Analysis of soil quality indicators}

Soil samples were dried at $105{ }^{\circ} \mathrm{C}$ and ball milled before $\mathrm{C}$ and $\mathrm{N}$ analysis by dry combustion (Elemental analyzer, Vario EL III, Jena, Germany). Soil C and N stocks were calculated based on the $\mathrm{C}$ and $\mathrm{N}$ contents and soil densities (it varied between $0.7-1 \mathrm{~g} \mathrm{~cm}^{-3}$ for forest soils and was $1.2 \mathrm{~g} \mathrm{~cm}^{-3}$ for the agricultural soil). Soil solution was obtained by the centrifugal drainage procedure described in Glanville et al. (2012) using 100g of fresh soil samples. The concentration of $\mathrm{NH}_{4}^{+}$in soil solution was determined colorimetrically using the sodiumnitroprusside, while $\mathrm{NO}_{3}{ }^{-}$was determined colorimetrically using the $\mathrm{VCl}_{3}$ (both procedures described in Mulvaney (1996)).

\subsection{Phospholipid fatty acids analysis}

Phospholipid fatty acids (PLFAs) were extracted from the soil samples according to Frostegard (1991). Briefly, $4.5 \mathrm{~g}$ of fresh soil were placed into $50 \mathrm{ml}$ centrifuge tubes, $25 \mu \mathrm{l}$ of internal standard one added ( $1 \mu \mathrm{g} \mu \mathrm{l}^{-1}, 19: 0$ phospholipid) and lipids extracted twice (18 and $6 \mathrm{ml}$, respectively) by one phase mixture of chloroform, methanol and citric acid $(0.15 \mathrm{M}, \mathrm{pH} 4.0)$ in the ratio 1:2:0.8 (v/v/v). Extracted lipids were applied to the silica column and neutral-, glyco- and phospholipids were sequentially eluted from the column by chloroform $(5 \mathrm{ml})$, acetone $(20 \mathrm{ml})$ and methanol $(20 \mathrm{ml})$, respectively. Collected phospholipids were saponified $\left(0.3 \mathrm{M}\right.$ solution of $\mathrm{BF}_{3}$ in methanol), obtained fatty acids were methylated ( $1 \mathrm{M}$ solution of $\mathrm{NaOH}$ in methanol) and extracted in hexane. Finally, the samples were dried under a stream of $\mathrm{N}_{2}$ and redissolved in toluene $(185 \mu \mathrm{l})$ with addition of internal standard two (15 $\mu 1$ of 13:0 fatty acid methyl ester, $1 \mu \mathrm{g} \mu \mathrm{l}^{-1}$ ).

The PLFAs were measured by GC-MS, having the following parameters: columns $(15 \mathrm{~m}$ HP-1 methylpolysiloxane coupled with a 30 m HP-5 (5\% phenyl)-methylpolysiloxane column (both with an internal diameter of $0.25 \mathrm{~mm}$ and a film thickness of $0.25 \mu \mathrm{m})$ ), He flow of $2 \mathrm{ml} \mathrm{min}^{-1}$, and injection volume of $1 \mu \mathrm{l}$. The temperature program of GC-MS was set up to $80^{\circ} \mathrm{C}$ and then ramped to $164{ }^{\circ} \mathrm{C}$ at $10{ }^{\circ} \mathrm{C} \min ^{-1}$, then to $230{ }^{\circ} \mathrm{C}$ at $0.7^{\circ} \mathrm{C} \mathrm{min}{ }^{-1}$ and finally to $300{ }^{\circ} \mathrm{C}$ at $10{ }^{\circ} \mathrm{C} \mathrm{min}{ }^{-1}$. The quantity of PLFAs was calculated based on the 29 external standards (Gunina et al. 2014), which were prepared in 6 concentrations (Apostel et al. 2013). Final content of single PLFAs was presented as molar percentages (mol \%) and total content was presented as $\mathrm{nmol} \mathrm{g}^{-1}$ soil. Classification of PLFAs was done according to existing data on their presence in various groups of

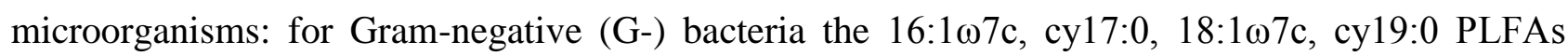
were used (Leckie 2005; Lewandowski et al. 2015), for Gram-positive bacteria (G+) i15:0, a15:0, 
i16:0, i17:0 PLFAs were used (Leckie 2005; Lewandowski et al. 2015), for actinomycetes (Ac) 10Me16:0 and 10Me18:0 were used (Lewandowski et al. 2015; Leckie 2005), for fungi

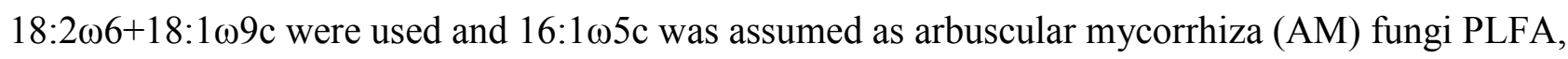
but with caution due to its high possible input from G- bacterial biomass (Leckie 2005; Lewandowski et al. 2015).

\subsection{Statistical analysis}

To compare the effect of forest development on soil chemical properties and on microbial biomarkers contents, changes of all parameters were calculated relatively to agricultural soil. Changes of the soil chemical properties (except $\mathrm{pH}$ ) relatively to the agricultural soil have been calculated as:

$$
\frac{C p_{f}-C p_{a g r}}{C p_{a g r}}
$$

where, $C p_{f}$ and $C p_{a g r}$ are the values of chemical properties in the forest and agricultural soils, respectively. For $\mathrm{pH}$ absolute changes were calculated by subtracting $\mathrm{pH}$ of agricultural soil from $\mathrm{pH}$ of forest soils.

The increase of PLFAs of distinct groups relatively to agricultural plot was calculated as:

$$
\frac{P L F A_{f}-P L F A_{a g r}}{P L F A_{a g r}}
$$

where, PLFA $\mathrm{f}$ and PLFA ${ }_{\text {agr }}$ are the contents of PLFAs of specific microbial groups in forest and agricultural soils (nmol $\mathrm{g}^{-1}$ soil), respectively. Data were checked for the normal distribution and homogeneity was tested by Levene's test. Calculated values were tested with one-way ANOVA and significant differences were obtained with Notched Box Plots.

Principal component analysis (PCA) of mol\% of individual PLFAs was done to elucidate major variation pattern. The scores of the first two components from the PCA were used to separate the soils formed under various forests. Linear regression of PLFAs factor scores and soil properties ( $\mathrm{pH}$, total $\mathrm{C}$ and $\mathrm{N}$, concentration of $\mathrm{NH}_{4}{ }^{+}$and $\mathrm{NO}_{3}{ }^{-}$) was done to conclude about the correlation of PLFAs composition with environmental factors depending on the forest type. Statistical analyses were done in Statistica 12.0 and Microsoft Excel 2010. 


\section{Results}

\subsection{Afforestation effects on soil properties}

Afforestation had weak effect on the $\mathrm{C}$ content: the maximal changes of soil $\mathrm{C}$ content was ca. $20 \%$ relative to the agricultural soil (Fig. 4-1), and was maximal for the birch, alder+oak and birch+beech plots. However, C stocks in the upper $10 \mathrm{~cm}$ under pure oak, beech, two species mixtures with oak and three species mixtures were lower compared to the agricultural soil (Supplementary Table 4-2), mainly because of the low bulk density of the forest soils (it varied between $0.7-1 \mathrm{~g} \mathrm{~cm}^{-3}$ for forest soils and was $1.2 \mathrm{~g} \mathrm{~cm}^{-3}$ for the agricultural soil).
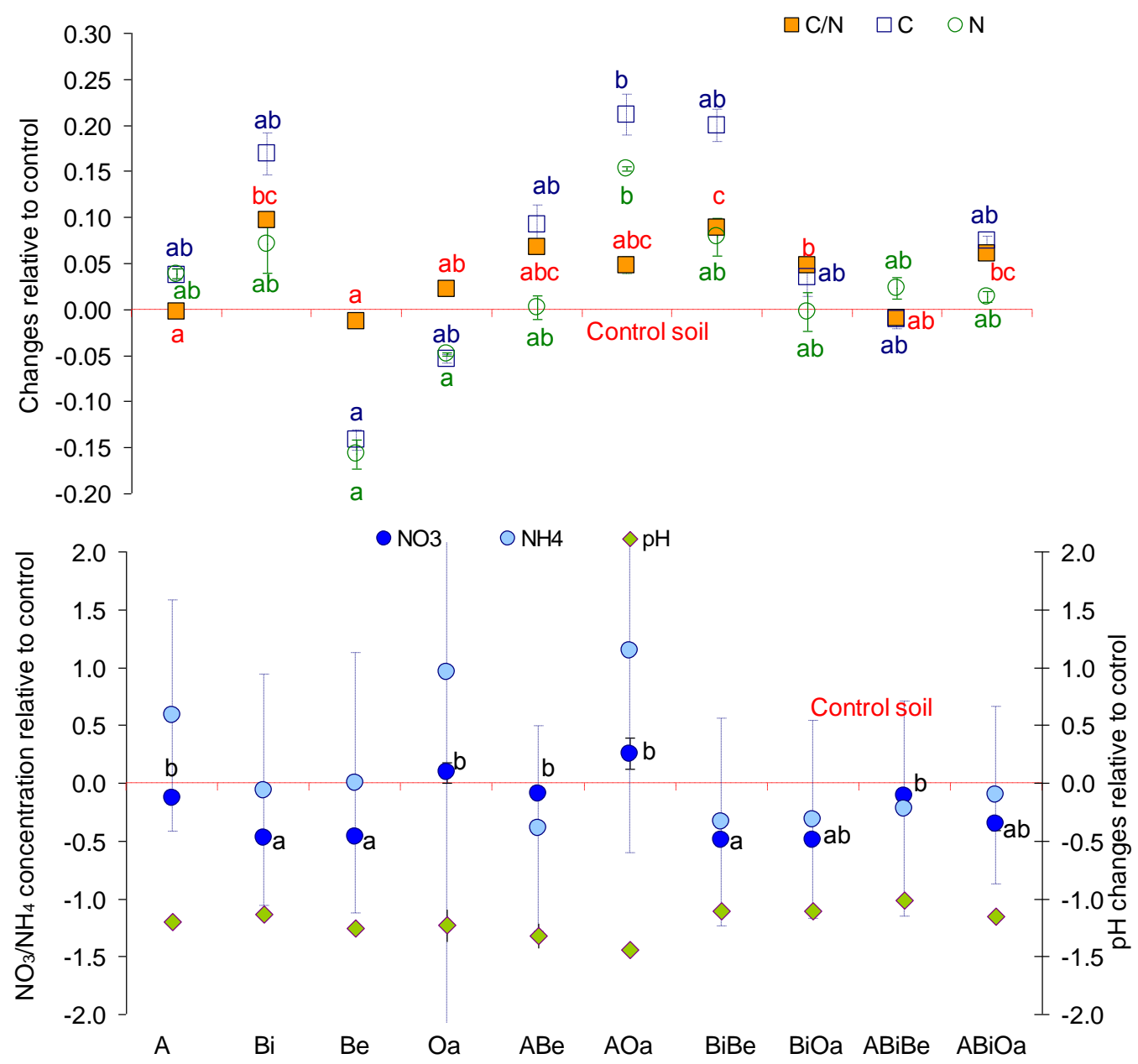

Figure 4-1. Changes of soil chemical properties in the various forest treatments relative to the agricultural soil (Agr). Data present mean \pm st. error, $n=4$. Letters above error bars present significant differences $(p<0.05)$ between the treatments for the each parameter separately. Red letters are for $C / N$ ratios, blue letter are for $C$ and green are for $N$. In case of $p H$ no statistical differences between the forests were found, only differences between forest and agricultural soil was found. Forest treatments: Al (alder), Bi (birch), Be (beech), Oa (oak), ABe (alder+beech), AOa (alder+oak), BiBe (birch+beech), BiOa (birch+oak), ABiBe (alder+birch+beech), ABiOa (alder+birch+oak). 
Table 4-1. Properties of the forest tree species.

\begin{tabular}{lcccc}
\hline Plant species & English oak & European beech & Silver birch & European alder \\
\hline $\begin{array}{l}\text { Succession stage } \\
\begin{array}{l}\text { Mycorrhization } \\
\text { degree }\end{array}\end{array}$ & Late & Late & Early primary & Early primary \\
$\begin{array}{l}\text { Type of } \\
\text { mycorrhization }\end{array}$ & Ecto & High & High & Weak \\
$\begin{array}{l}\text { C/N ratio of plant } \\
\text { litter }\end{array}$ & 38.73 & Ecto & Ecto & $\begin{array}{l}\text { Ecto- and } \\
\text { arbuscular }\end{array}$ \\
\hline
\end{tabular}

The effect of forest development on soil N content (Fig. 4-1) followed the same tendency as on $\mathrm{C}$ content, despite the contrasting $\mathrm{N}$ content of the various forest litters (Table 4-1). In general, changes of total $\mathrm{N}$ content in the forest soils were similar and ranged within $\pm 15 \%$. The organic matter quality, characterized by $\mathrm{C} / \mathrm{N}$ ratio, was the most strongly affected for the pure birch, birch+beech plots and alder+beech, where it had the highest increase relative to agricultural soil (Fig. 4-1).

10 years of afforestation decreased soil acidity by 1.0-1.2 units compared to the agricultural plot (Fig. 4-1).

The $\mathrm{NO}_{3}{ }^{-}$concentrations in soil solution decreased for the birch, beech and two forest mixtures with birch compare to the agricultural soil (Fig. 4-1). In contrast, $\mathrm{NH}_{4}{ }^{+}$did not differ in the agricultural and forest soils (Fig. 4-1).

\subsection{Afforestation effects on total PLFAs content}

Maximal contents of total microbial PLFAs were observed for the oak, birch and alder forest soils (Fig. 4-2). Total PLFA contents were higher for the oak, birch and alder monocultures forests compare to pure beech forest, whereas no differences were found between the two and three species mixtures. In the case of the two species mixtures where beech was present, total PLFA content increased relative to the beech monocultures, whereas, the opposite trends were observed for the pure oak forest and two species mixtures containing oak. 


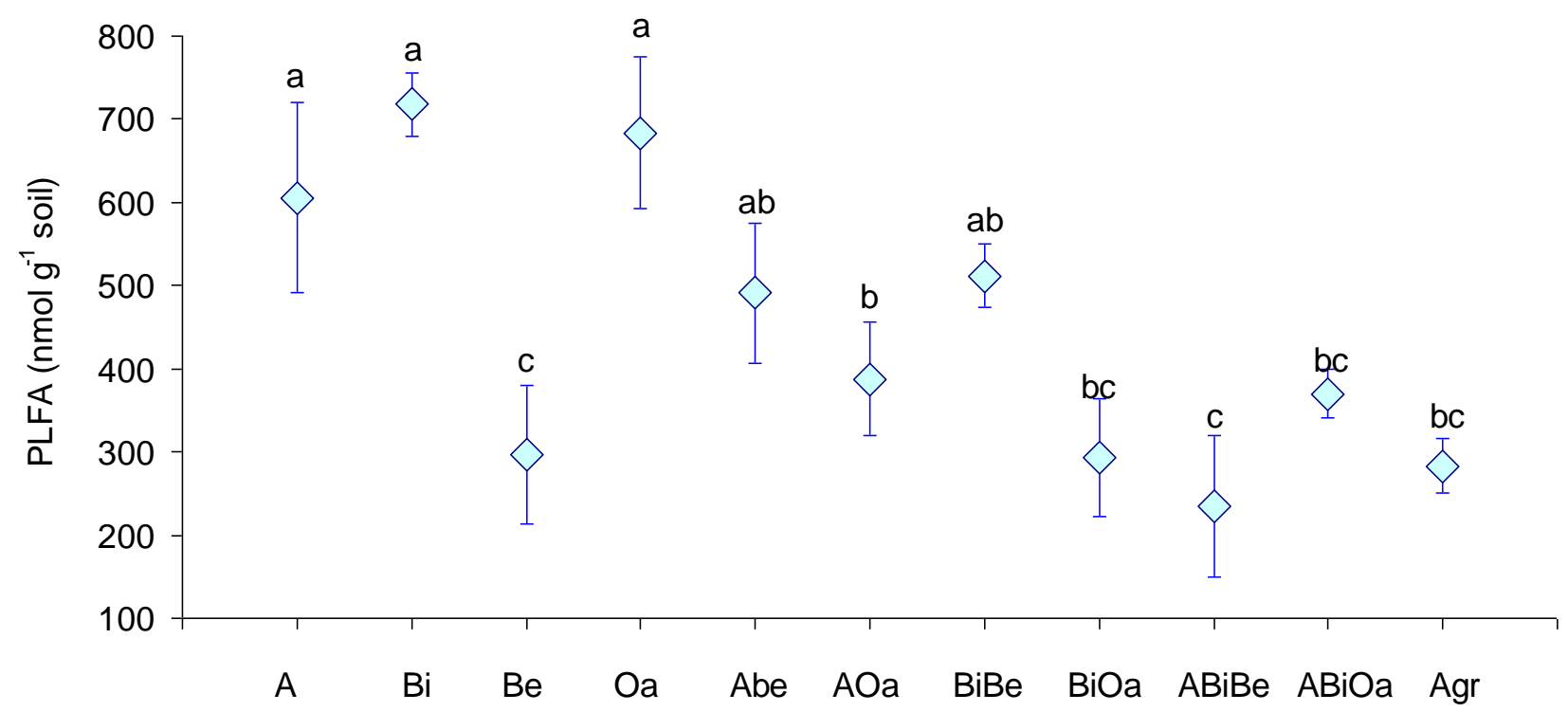

Figure 4-2. Content of total PLFAs (nmol $\mathrm{g}^{-1}$ soil) in the different forest treatments and the agricultural soil. Data present mean \pm st error, $n=4$. Letters above error bars present significant differences ( $p<0.05)$ between the treatments. Forest treatments: Al (alder), Bi (birch), Be (beech), Oa (oak), ABe (alder+beech), AOa (alder+oak), BiBe (birch+beech), BiOa (birch+oak), ABiBe (alder+birch+beech), ABiOa (alder+birch+oak).

\subsection{Afforestation effects on the content of specific microbial biomarkers}

Afforestation increased fungal PLFAs content the most compared to other biomarkers, and were 50-200\% higher in the forest soils compared to the agricultural (Fig. 4-3). The maximal increase was found for the soils under birch, oak, alder and birch+beech. The two and three species forests increased their fungal biomarker content by $50-100 \%$.

Bacterial biomarkers increased in forest soils (except beech, three species mixture with beech and birch+oak) by 20 to $110 \%$ compared to the arable soil but without differences in the G+ and G- groups (Fig. 4-3). The content of G+ bacterial PLFAs were low for the monocultural beech forest, but increased for the two species mixtures with beech. In contrast, the content of G+ PLFAs were higher for the monocultural oak forests, than for the birch+oak mixed forest.

Relative to the agricultural, the content of 16:1@5 PLFAs (AM fungal or G- bacterial biomarker) increased by 30-120\% (Fig. 4-3) and the increase was higher under the birch and oak treatments than for any other soils. Both beech alone and in three species mixtures forests containing beech resulted in a decline of 16:1ø5 PLFAs relative to the agricultural soil. 
The content of actinomycete PLFAs followed the same trend as 16:1@5 PLFA, however, the highest increase was found for the alder+beech plot.

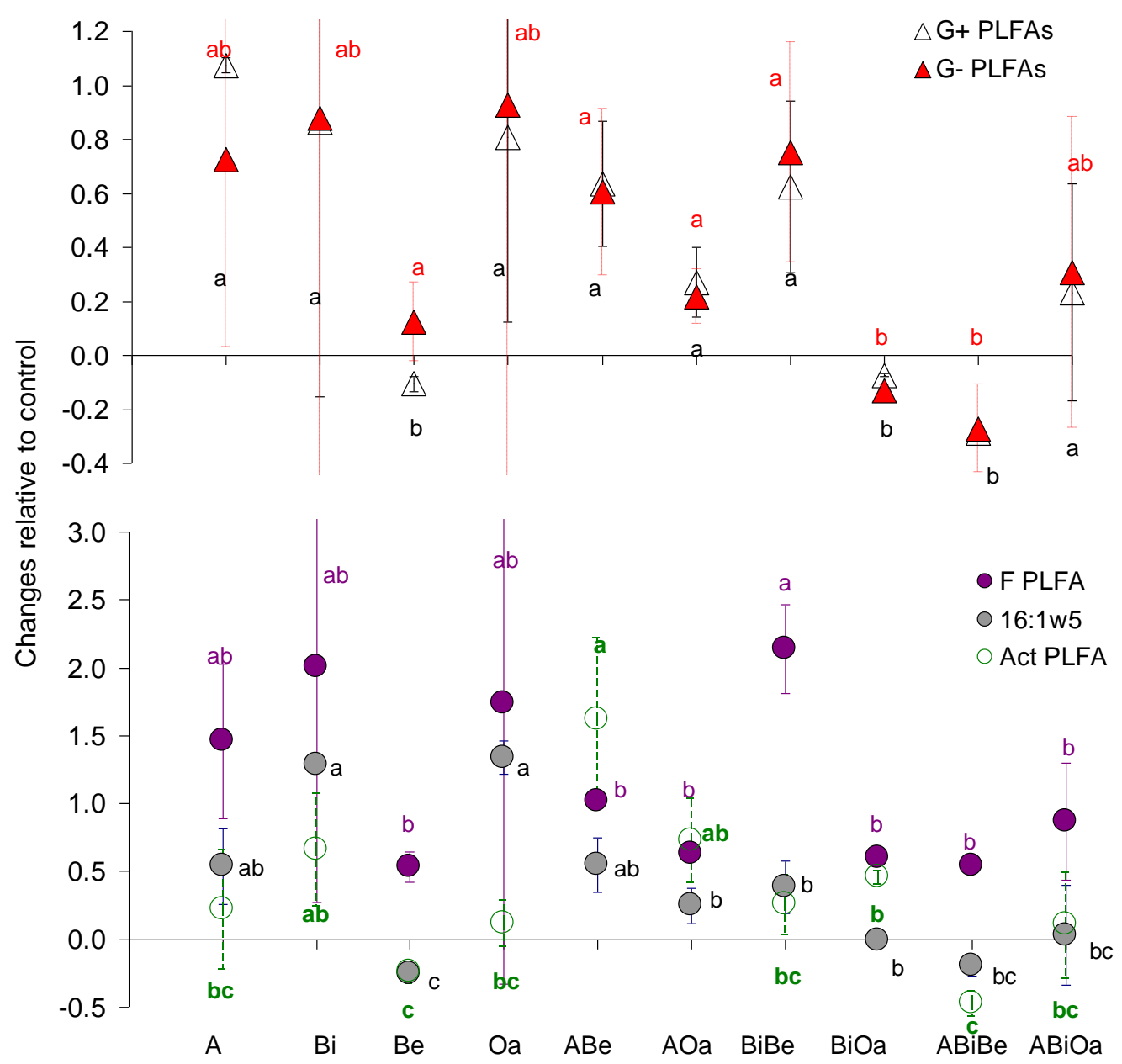

Figure 4-3. Changes in the content (nmol $g^{-1}$ soil) of specific microbial indicators PLFAs in the different forest treatments relative to the agricultural soils, presented as portion of changes. Data present mean \pm st. error, $n=4$. Letters above error bars present significant differences $(p<0.05)$ between the plots for the each group separately. Top figure - red letters are for G-bacterial PLFAs, black letters are for G+ PLFAs; bottom figure - violett letters are for fungal PLFAs, black are for 16:1w5 PLFA and green are for actinomycetes PLFAs. Forest treatments: Al (alder), Bi (birch), Be (beech), Oa (oak), ABe (alder+beech), AOa (alder+oak), BiBe (birch+beech), BiOa (birch+oak), ABiBe (alder+birch+beech), ABiOa (alder+birch+oak). 
PCA analysis of the PLFA data revealed that the first two PCA components explained 38 and $21 \%$ of the PLFA variation, respectively (Fig. 4-4). The first PCA component reflects differences in soil $\mathrm{pH}\left(r^{2}=0.32\right.$; linear regression of scores for PC1 vs. soil $\left.\mathrm{pH}\right)$ and was correlated with saturated/monounsaturated ratio $\left(r^{2}=0.45\right)$. The second PCA component was correlated with fungal/bacterial ratio $\left(r^{2}=0.69\right)$ and also can be explained by soil $\mathrm{pH}\left(r^{2}=0.73\right)$. Both PC1 and PC2 were correlated with the cyclo/precursor ratio (for PC1 $r^{2}=0.38$ and for PC2 $r^{2}=0.40$ ). Both ratios are presented in the Table 4-2.

Table 4-2. Ratios of saturated/monounsaturated (sat/mono) PLFAs (calculated as

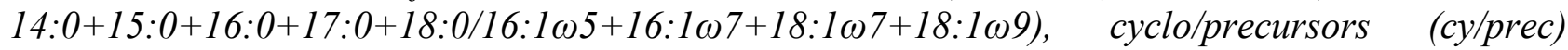

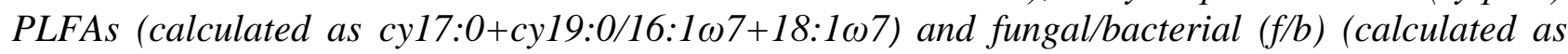

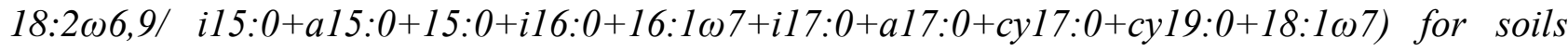
under the different forest treatments and the grassland control plots. Data present mean \pm st. error, $n=4$. Forest treatments: Al (alder), Bi (birch), Be (beech), Oa (oak), ABe (alder+beech), AOa (alder+oak), BiBe (birch+beech), BiOa (birch+oak), ABiBe (alder+birch+beech), ABiOa (alder+birch+oak); Agr-agricultural plot.

\begin{tabular}{|c|c|c|c|c|c|c|c|c|c|c|c|}
\hline Forest & $\bar{A}$ & $\overline{\mathrm{Bi}}$ & $\mathrm{Be}$ & $\mathrm{Oa}$ & $\mathrm{ABe}$ & $\mathrm{AOa}$ & $\mathrm{BiBe}$ & $\mathrm{BiOa}$ & $\mathrm{ABiBe}$ & $\mathrm{ABiOa}$ & Agr \\
\hline & 0.65 & 1 & $0.69 \pm$ & $068+$ & $0.7 \pm$ & $\overline{78}$ & $0.63 \pm$ & $\overline{72}$ & $0.58 \pm 0.02$ & $\overline{3}$ & 0.6 \\
\hline cy/p & 0.49 & $0.55 \pm 0.02$ & 0.5 & 4 & 0. & 0.5 & 0.5 & 0.47 & 0.5 & 0.5 & \\
\hline$f / b$ & $0.043 \pm 0.006$ & $0.063 \pm 0.004$ & $0.05 \pm 0.004$ & $0.054 \pm 0.007$ & $0.069 \pm$ & $0.062 \pm 0.003$ & $0.076 \pm 0.013$ & $0.074 \pm 0.004$ & $0.064 \pm 0.01$ & $0.055 \pm 0.009$ & $0.033 \pm 0.001$ \\
\hline
\end{tabular}

According to the PCA results the agricultural soil was separated from the mono- and three species mixture forests along the PC1 and PC2 and only along PC2 from the two species mixtures

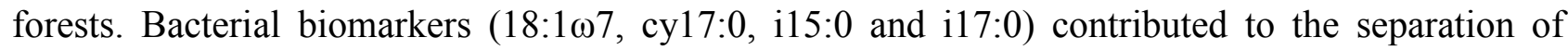

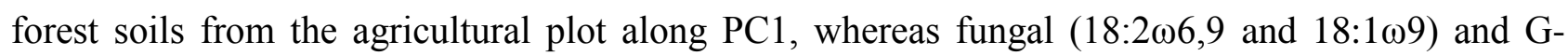
biomarkers (cy19:0) were responsible for the separation along PC2 (Fig. 4-4, top). The agricultural

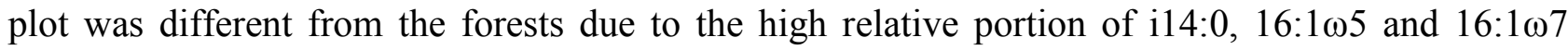
PLFAs in total PLFAs content, which were 1.1-1.5 times higher in the agricultural relative to the forest soils (Supplementary table 4-1). 

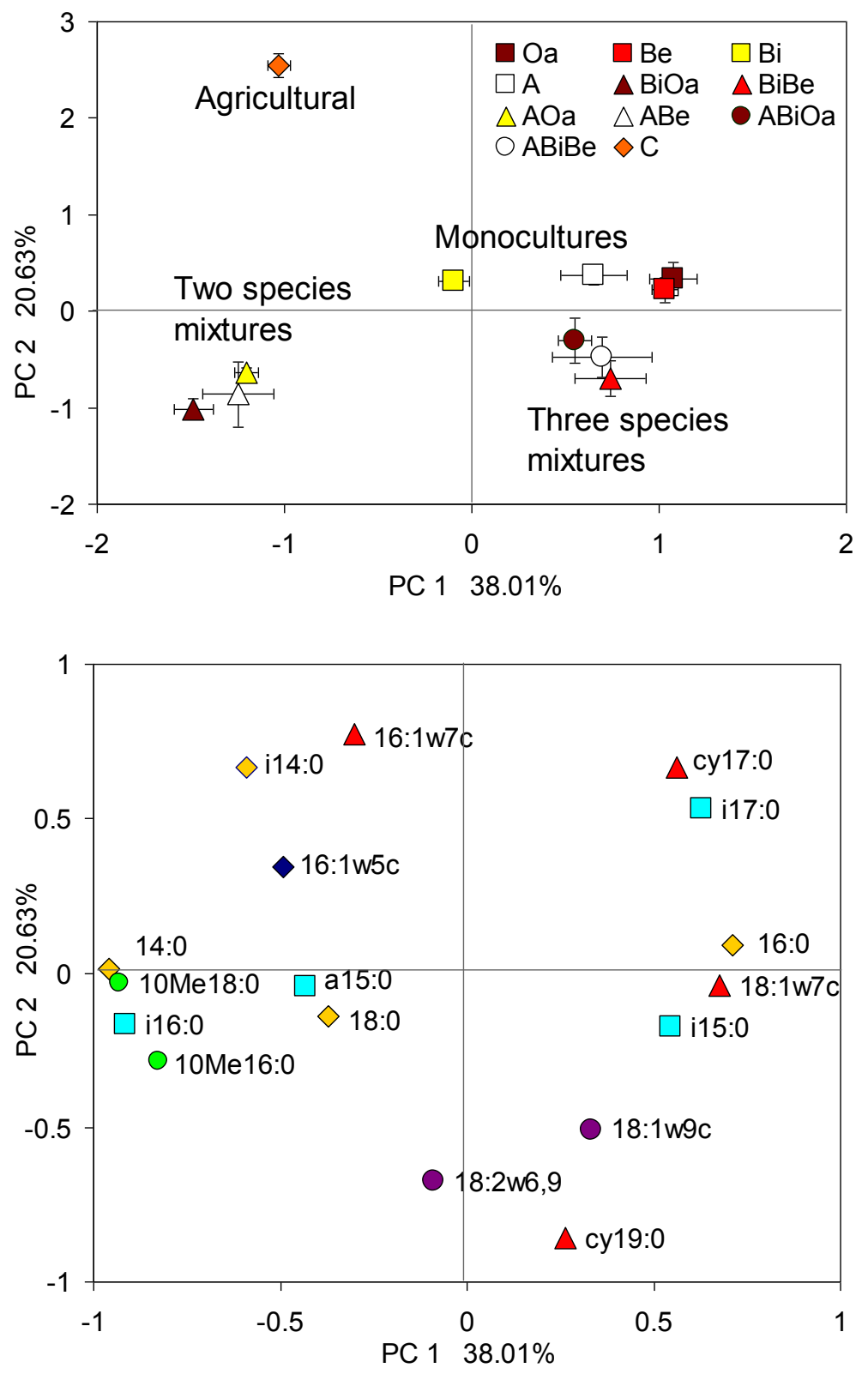

Figure 4-4. Score plot of PCA presenting the separation of mono-and mixture species forests along the principal component PC1 and PC2 (top) and loading values for the PLFAs (bottom). Forest treatments: Al (alder), Bi (birch), Be (beech), Oa (oak), ABe (alder+beech), AOa (alder+oak), BiBe (birch+beech), BiOa (birch+oak), ABiBe (alder+birch+beech), ABiOa (alder+birch+oak). Colors for the loading values of PLFAs indicate the following: red - Gram-negative bacterial, yellow universal microbial biomarker, green - actinomycetes, blue - Gram-positive bacteria, violet-fungi.

Single and three species mixtures forest soils were separated from the two species mixture forests along PC1 (Fig. 4-4, top). Based on the loading values (Fig. 4-4, bottom), Ac (10Me16:0

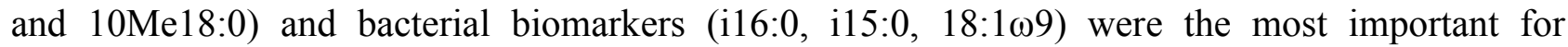
separation the two species mixtures from single and three species mixtures forests. In contrast, mono- and three species mixtures were only weakly separated on PC 2, and no separation along PC1 was found. 


\section{Discussion}

\subsection{Afforestation effects on soil chemical properties}

Afforestation typically results in an improvement in soil quality and an increase in total C and N content (Laganière et al. 2012; Kurganova et al. 2015; Paul et al. 2002). Soil C content increased by $20 \%$ (for some plots) in the top $10 \mathrm{~cm}$ when compared to the adjacent agricultural on which the forest was established (Fig. 4-1). Such small changes are related to: i) prolonged effects of former land use management on the total soil $\mathrm{C}$ content within the first 10 years after afforestation (Paul et al. 2002), ii) occurrence of opposing processes during afforestation: a) large inputs of tree litter which decomposes relatively slowly as the intrinsic microbial community is poorly adapted to this new substrate, and at the same time b) intensive decomposition of the intrinsic agriculture-derived SOC due to the increased activity and content of microbial biomass. As a result, $\mathrm{C}$ mineralization can exceed accumulation in the surface soil layer during early afforestation.

Total soil $\mathrm{N}$ content in the forest soils were similar to the agricultural plot, except for pure beech stand, where it decreased by $15 \%$ and alder+oak plot where $\mathrm{N}$ content increased by $15 \%$ (Fig. 4-1). N stocks were lower in all forest soils compared to the agricultural soil (Supplementary Table 4-2), mainly because of decrease of soil density. Afforestation has a strong effect on $\mathrm{N}$ dynamics in soils and induces changes in $\mathrm{N}$ mineralization, ammonification and nitrification rates (Li et al. 2014). Moreover, young trees have a high demand for $\mathrm{N}$, resulting in a redistribution from soils into tree biomass (Uri et al. 2003). The dominating form of the $\mathrm{N}$ in soil solution in afforested soils was nitrate, although this was lower than in the agricultural soil (Fig. 4-1, Supplementary Table 4-2). In contrast, no strong effect of afforestation on $\mathrm{NH}_{4}{ }^{+}$concentration was found. The decrease of $\mathrm{NO}_{3}{ }^{-}$concentrations is common for forest soils is a consequence of lower $\mathrm{pH}$, higher $\mathrm{C}$ input, absence of fertilization and intensive uptake of $\mathrm{N}$ by plants, all of which reduce nitrification rates ( $\mathrm{Li}$ et al. 2014).

In agreement with previous afforestation studies (Berthrong et al. 2009; Kalinina et al. 2011), a decrease in soil $\mathrm{pH}$ was observed in all forest plots. We ascribe this to, i) changes in the amount of rhizodeposition, which is around $50 \%$ of total assimilated $\mathrm{C}$ belowground for trees vs. 10-40\% for annual plants (Grayston et al. 1997a), ii) changes in root and ectomycorrhizal exudate quality, which often contain a high variety and amount of organic acids (Grayston et al. 1997a), iii) an increased uptake of cations by trees (Jobbágy and Jackson 2003), iv) shifts in litter quality, and v) an absence of liming. We conclude therefore that while early afforestation does not promote 
strong changes in some soil chemical properties (e.g. total $\mathrm{C}$ and $\mathrm{N}$ content, $\mathrm{C} / \mathrm{N}$ ratio) it can promote large changes in more dynamic soil quality indicators (e.g. $\mathrm{pH}$ and available $\mathrm{N}$ form).

\subsection{Tree identity effects on total microbial PLFA}

Development of forests usually increases total PLFAs content (Jangid et al. 2011) and for our study it was true mostly for the soils under the monoculture forests formed by alder, birch and oak and also in two species forest mixtures with beech (Fig. 4-2). The total content of PLFAs was 2-3 times lower for the pure beech stands in comparison with the other broadleaf forest types (e.g. hornbeam, lime, maple or ash) (Scheibe et al. 2015). This is a consequence of low $\mathrm{pH}$ and presence of specific compounds in root exudates composition (Scheibe et al. 2015). The increase of PLFAs content under the two species mixtures with beech is explained by presence of the pioneer species alder and birch, which are usually used to improve soil quality before planting the secondary forest species such as beech (Frouz et al. 2015). Moreover, alder is an N-fixer, which can provide additional $\mathrm{N}$ for microorganisms in soil under two species mixtures forests (Frouz et al. 2015; Walker and Chapin 1986; Chapin et al. 1994). In contrast, mixtures containing both oak trees and primary succession species did not stimulate an increase in microbial biomarkers content (Fig. 4-2). The same effect was found for the three species mixtures because partly opposite effects of the tree species (Fig. 4-2) compensating each other in mixtures. In conclusion, it appears that tree species identity has a stronger effect than amount of species on the content of total PLFAs in the afforested soils.

\subsection{Afforestation effects on microbial community composition}

Afforestation increased the content of bacterial and fungal PLFAs, however, fungal biomarkers increased 2 times higher than those for bacterial. Afforestation usually promotes development of fungi (Yannikos et al. 2014; Macdonald et al. 2009; Carson et al. 2010) and induces changes in fungal community composition (Carson et al. 2010). An increase in fungal biomarker content after afforestation can be attributed to the both direct effects of the trees themselves and indirect effects due to changes in the environment. Of the direct tree effects, fungal biomass is stimulated by, i) a shift from easy decomposable crop residues to more recalcitrant leaf litter rich in polyphenol/tannin compounds (Rousk and Baath 2007; Yannikos et al. 2014), and ii) development of plant species, which are strongly ectomycorrhizal such as birch, alder and oak (Baum et al. 2009). Of the indirect effects, i) termination of agricultural practice stimulates the development of 
fungi due to less physical disruption of hyphal networks (Helgason et al. 2009; Strickland and Rousk 2010), and ii) a decrease in soil $\mathrm{pH}$ suppresses bacterial growth and makes fungi more competitive in terms of substrate utilization (Swift et al. 1979; Zeller et al. 2001).

The 16:1 $\omega 5$ PLFA can be used to estimate the content of AM fungal biomarkers (Thoms and Gleixner 2013; Madan et al. 2002) although we acknowledge that this may also be present in Gbacteria (Nichols et al. 1986). In contrast to fungal PLFAs, the content of the 16:165 PLFA increased by 30 to $120 \%$ (for some cases) and even decreased (for beech and three species forest mixtures) (Fig. 4-3). This either can reflect i) the shift in fungal community from arbuscular mycorrhizal communities, inherent for agriculture and pasture soils, to ectomycorrhizal communities which dominate under forests (Macdonald et al. 2009) or ii) the changes in portion of microorganisms with rapid growth strategy in total microbial community (Priha et al. 1999).

Bacterial biomass was less affected by a shift away from an agricultural management regime than fungi. This is agreement with Klein et al. (1995) who suggested that abandonment of agricultural land and subsequent afforestation should not strongly affect that part of soil microbial community. However, based on our PLFA analysis, the amount of bacterial biomarkers increased with afforestation, which agrees with other findings (van der Wal et al. 2006). Also, there was a similar increase of G+ and G- biomarkers in the most forest plots (except three species mixtures with beech and birch+oak) (Fig. 4-3), which is in one line with data on similar portions of G+ and G- PLFAs found for the old growing oak and beech forests (Hackl et al. 2005). Increases in the Gbacterial biomarkers may be connected with the increasing the volume of rhizosphere in forest soils compare to agricultural (Thoms and Gleixner 2013), whereas increases in G+ biomarkers may occur due to intensive decomposition of $\mathrm{C}$ from previous land use.

The average increase of PLFAs associated with actinomycetes was 50-150\% and was detected only for pure birch stand and two species mixtures (the highest with presence of alder), whereas for other plots they decreased or were similar to the agricultural soil (Fig. 4-3). Decrease in actinomycete biomarker content is related to the increasing the content of fungal biomass which is known to suppress the development of the actinomycete community (Lewandowski et al. 2015; Boer et al. 2005). From this study we conclude that changes in the content of microbial biomarkers following afforestation were greater compared to the major soil quality indicators. Afforestation affected the development of fungal biomass to a greater degree than bacterial biomass. Shifts in the content of particular biomarkers was found in all forest plots, suggesting that the amount of tree species is not the main factor controlling soil microbial community changes. At the same time, the 
relative increase in biomarker content was related to tree identity, revealing that individual tree species promoted greater change relative to mixed-species forest. Further, no additive effects of individual tree species were found.

\subsection{Forest composition effects on soil microbial communities}

According to PCA analysis forest soil plots were different from the agricultural plot mainly

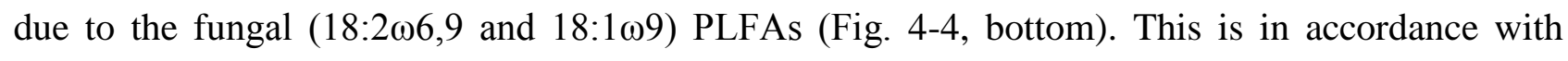
general increase of fungal biomarkers in forest soils (Fig. 4-3). Decrease of soil acidity contributed the most to separation of forest and agricultural plots, which is frequently reported for forest soils (Scheibe et al. 2015; van der Wal et al. 2006).

According to the PCA, one- and three species mixture forests were more similar in PLFA composition than two species mixtures (Fig. 4-4, top). The most relevant groups in differentiation of two species mixtures from monoculture and three species forests were 10Me16:0 and 10Me18:0, common for actinomycetes (Zelles 1997) and branched PLFAs i16:0 and a16:0, common for G+ bacteria (Zelles 1997) (Fig. 4-4, bottom). The late successional tree species together with two early primary successional species (three species mixture forests) stimulates development of microbial communities similar to monoculture forests (Fig. 4-4, top). The most relevant PLFAs for separation

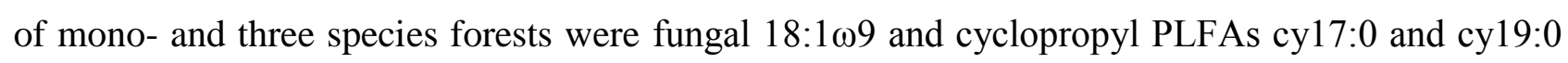
(Fig. 4-4, bottom).

Thus, the specific microbial community types were formed in the soils under the tested forest types already 10 years after planting. Similar microbial communities developed in soils under mono- and three species forest mixtures point on the absence of additive effect if two early primary successional species grow together. In contrast, simultaneous development of one early primary and one late successional tree species forms soil microbial communities with completely different composition.

\section{Conclusions}

Afforestation by one-, two- and three species mixtures with contrasting sets of functional traits, revealed the effects of trees identity and forest tree community composition on changes in soil chemistry and the structure of microbial communities. In support of our first hypothesis, total PLFA content increased more than $100 \%$ in forest soils compared to the agricultural, whereas changes in soil chemical properties ( $\mathrm{C}$ and $\mathrm{N}$ contents, dissolved $\mathrm{N}$ forms) were altered to a lesser 
degree. Total PLFA contents for monocultural forests (except beech) were higher than for the mixtures, indicating that tree species identity has a stronger effect than number of species on the content of microbial biomarkers and no additive effects of increasing species number were observed.

The content of fungal biomarkers was changed by afforestation to much greater extent than for bacteria in agreement with our second hypothesis. Increase of particular biomarkers for all forests was independent of tree species amount, reflecting absence of additive effect of forest mixtures on the content of specific microbial biomarkers.

The PCA analysis revealed that two species mixtures were separated from one- and three species forests due to a higher abundance of actinomycetes and G+ bacterial biomarkers. In contrast, microbial community composition for single species forests were similar to the three species mixtures, and could only be separated along PC2 due to a high abundance of G- bacterial biomarkers. Thus, development of forest monocultures, even formed by species having different functional traits promotes formation of similar microbial communities. In contrast, the simultaneous presence of early primary and late successional tree species stimulates the development of different community compositions, but this effect is dampened in mixtures of two early primary and late successional species. 


\section{Acknowledgements}

This study was supported by a grant from the Erasmus Mundus Joint Doctoral Programme "Forest and Nature for Society" (FONASO) awarded to A. Gunina. BangorDIVERSE was supported by the Sêr Cymru National Research Network for Low Carbon Energy and Environment.

\section{References}

Ahmed IU, Smith AR, Jones DL, Godbold DL (2016) Tree species identity influences the vertical distribution of labile and recalcitrant carbon in a temperate deciduous forest soil. Special Section: Forests, Roots and Soil Carbon. Forest Ecology and Management 359:352-360. doi:10.1016/j.foreco.2015.07.018.

Apostel C, Dippold MA, Glaser B, Kuzyakov Y (2013) Biochemical pathways of amino acids in soil. Assessment by position-specific labeling and 13C-PLFA analysis. Soil Biology \& Biochemistry 67:31-40.

Baum C, Toljander YK, Eckhardt K-U, Weih M (2009) The significance of host-fungus combinations in ectomycorrhizal symbioses for the chemical quality of willow foliage. Plant and Soil 323:213-224. doi:10.1007/s11104-009-9928-x.

Berthrong ST, Jobbaagy EG, Jackson RB (2009) A global meta-analysis of soil exchangeable cations, pH, carbon, and nitrogen with afforestation. Ecological Applications 19:2228-2241.

Boer WD, Folman LB, Summerbell RC, Boddy L (2005) Living in a fungal world: impact of fungi on soil bacterial niche development. FEMS Microbiology Reviews 29:795-811. doi:10.1016/j.femsre.2004.11.005.

Buckley DH, Schmidt TM (2003) Diversity and dynamics of microbial communities in soils from agroecosystems. Environmental Microbiology 5:441-452.

Carson JK, Gleeson DB, Clipson N, Murphy DV (2010) Afforestation alters community structure of soil fungi. Fungal Biology 114:580-584. doi:10.1016/j.funbio.2010.04.008.

Chapin FS, Walker LR, Fastie CL, Sharman LC (1994) Mechanisms of Primary Succession Following Deglaciation at Glacier Bay, Alaska. Ecological Monographs 64:149-175.

Cong J, Yang Y, Liu X, Lu H, Liu X, Zhou J, Li D, Yin H, Ding J, Zhang Y (2015) Analyses of soil microbial community compositions and functional genes reveal potential consequences of natural forest succession. Scientific reports 5:10007. doi:10.1038/srep10007.

DeLuca TH, Boisvenue C (2012) Boreal forest soil carbon: distribution,function and modelling. Forestry doi:10.1093/forestry/cps003.

Frostegard A, Tunlid A, Baath E (1991) Microbial biomass measured as total lipid phosphate in soils of different organic content. Journal of Microbiological Methods 14:151-163. doi:10.1016/0167-7012(91)90018-1.

Frouz J, Voborilová V., Janoušová I., Kadochová Š, Matejícek L (2015) Spontaneous establishment of late successional tree species Englishoak (Quercus robur) and European beech (Fagus sylvatica) at reclaimed alder plantation and unreclaimed post mining sites. Ecological Engineering 77:1-8. 
Fu X, Yang F, Wang J, Di Y, Dai X, Zhang X, H W (2015) Understory vegetation leads to changes in soil acidity and in microbial communities 27 years after reforestation. Science of the Total Environment 502:280-286.

Glanville H, Rousk J, Golyshin P, Jones DL (2012) Mineralization of low molecular weight carbon substrates in soil solution under laboratory and field conditions. Soil Biology \& Biochemistry 48:88-95. doi:10.1016/j.soilbio.2012.01.015.

Grayston SJ, Vaughan D, Jones D (1997a) Rhizosphere carbon flow in trees, in comparison with annual plants. The importance of root exudation and its impact on microbial activity and nutrient availability. Applied Soil Ecology 5:29-56. doi:10.1016/s0929-1393(96)00126-6.

Grayston SJ, Vaughan D, Jones D (1997b) Rhizosphere carbon flow in trees, in comparison with annual plants. The importance of root exudation and its impact on microbial activity and nutrient availability. Applied Soil Ecology 5:29-56. doi:10.1016/s0929-1393(96)00126-6.

Gunina A, Dippold M, Glaser B, Kuzyakov Y (2014) Fate of low molecular weight organic substances in an arable soil. From microbial uptake to utilisation and stabilisation. Soil Biology \& Biochemistry 77:304-313.

Hackl E, Pfeffer M, Donat C, Bachmann G, Zechmeister-Boltenstern S (2005) Composition of the microbial communities in the mineral soil under different types of natural forest. Soil Biology \& Biochemistry 37:661-671.

Helgason BL, Walley FL, Germida JJ (2009) Fungal and bacterial abundance inlong-term no-till and intensive-till soils of the Northern Great Plains. Soil Sci. Soc. Am. J. 73:120-127.

Jangid K, Williams MA, Franzluebbers AJ, Schmidt TM, Coleman DC, Whitman WB (2011) Landuse history has a stronger impact on soil microbial communitycomposition than aboveground vegetation and soil properties. Soil Biology \& Biochemistry xxx:1-10.

Jobbágy EG, Jackson RB (2003) Patterns and mechanisms of soil acidification in the conversion of grasslands to forests. Biogeochemistry 64:205-229. doi:10.1023/A:1024985629259.

Kalinina O, Krause SE, Goryachkin SV, Karavaeva NA, Lyuri DI, Giani L (2011) Self restoration of post-agrogenic chernozems of Russia: soil development, carbon stocks, and dynamics of carbon pools. Geoderma 162:196-206.

Klein DA, McLendon T, Paschke MW, Redente EE (1995) Saprophytic fungal-bacterial biomass variations in successional communities of a semi-arid steppe ecosystem. Biology and Fertility of Soils 19:253-256.

Kurganova I, Lopes De Gerenyu V, Kuzyakov Y (2015) Large-scale carbon sequestration in postagrogenic ecosystems in Russia and Kazakhstan. Catena 133:461-466. doi:10.1016/j.catena.2015.06.002.

Laganière J, Paré D, Bergeron Y, Chen H (2012) The effect of boreal forest composition on soil respiration is mediated throughvariations in soil temperature and C quality. Soil Biology \& Biochemistry 53:18-27.

Leckie SE (2005) Methods of microbial community profiling and their application to forest soils. Forest Ecology and Management 220:88-106.

Lewandowski TE, Forrester JA, Mladenoff DJ, Stoffel JL, Gower ST, D’Amato AW, Balser TC (2015) Soil microbial community response and recovery following group selection harvest. 
Temporal patterns from an experimental harvest in a US northern hardwood forest. Forest Ecology and Management 340:82-94.

Li H, Ye D, Wang X, Settles ML, Wang J, Hao Z, Zhou L, Dong P, Jiang Y, Ma Z Soil bacterial communities of different natural forest types in Northeast China. Plant and Soil 383:203-216. doi:10.1007/s11104-014-2165-y.

Li M, Zhou X, Zhang Q, Cheng X (2014) Consequences of afforestation for soil nitrogen dynamics in central China. Agriculture, Ecosystems and Environment 183:40-46.

Macdonald CA, Thomas N, Robinson L, Tate KR, Ross DJ, Dando J, Singh BK (2009) Physiological, biochemical and molecular responses of the soil microbial community after afforestation of pastures withPinus radiata. Soil Biology \& Biochemistry 41:1642-1651.

Madan R, Pankhurst C, Hawke B, Smith S (2002) Use of fatty acids for identification of AM fungi and estimation of the biomass of AM spores in soil. Soil Biology \& Biochemistry 34:125-128. doi:10.1016/s0038-0717(01)00151-1.

Mann L, Tolbert V (2000) Soil sustainability in renewable biomass plantings. Ambio 29:492-498.

Mulvaney RL (1996) Methods of Soil Analysis. Part 3 - Chemical Methods. Nitrogen - Inorganic Forms. Soil Science Society of America, Inc., Wisconsin, USA.

Nazaries L, Tottey W, Robinson L, Khachane A, Al-Soudd WA, Sørensen S, Singh BK (2015) Shifts in the microbial community structure explain the response of soil respiration to land-use change but not to climate warming. Soil Biology \& Biochemistry 89:123-134.

Nichols P, Stulp BK, Jones JG, White DC (1986) Comparison of fatty acid contentand DNA homology of the filamentous gliding bacteria Vitreoscilla, Flexibacter,Filibacter. Archives of Microbiology 146:1-6.

Paul KI, Polglase PJ, Nyakuengama JG, Khanna PK (2002) Change in soil carbon following afforestation. Forest Ecology and Management 168:241-257. doi:10.1016/S03781127(01)00740-X.

Priha O, Grayston SJ, Pennanen T, Smolander A (1999) Microbial activities related to C and N cycling and microbial community structure in the rhizospheres ofPinus sylvestris, Picea abiesandBetula pendulaseedlings in an organic and mineral soil. Fems Microbiology Ecology 30:187-199.

Ritter E, Vesterdal L, Gundersen P (2003) Changes in soil properties after afforestation of former intensively managed soils with oak and Norway spruce. Plant and Soil 249:319-330.

Rousk J, Baath E (2007) Fungal biomass production and turnover in soil estimated using the acetate-in-ergosterol technique. Soil Biology \& Biochemistry 39:2173-2177. doi:10.1016/j.soilbio.2007.03.023.

Scheibe A, Steffens C, Seven J, Jacob A, Hertel D, Leuschner C, Gleixner G (2015) Effects of tree identity dominate over tree diversity on the soil microbial community structure. Soil Biology \& Biochemistry 81:219-227.

Smith A., Lukac M., Hood R., Healey J.R., Miglietta F., Godbold D.L. (2013) Elevated CO2 enrichment induces a differential biomass response in a mixed species temperate forest plantation. New Phytologist 198:156-168. 
Strickland MS, Rousk J (2010) Considering fungal. bacterial dominance in soils - Methods, controls, and ecosystem implications. Soil Biology \& Biochemistry 42:1385-1395. doi:10.1016/j.soilbio.2010.05.007.

Swift MJ, Heal OW, Anderson JM (1979) Decomposition in Terrestrial Ecosystems. Oxford.

Thoms C, Gleixner G (2013) Seasonal differences in tree species' influence on soil microbial communities. Soil Biology \& Biochemistry 66:239-248.

Trap J, Hättenschwiler S, Gattin I, Aubert M (2013) Forest ageing: An unexpected driver of beech leaf litter quality variability in European forests with strong consequences on soil processes. Forest Ecology and Management 302:338-345.

Uri V, Lohmus K, Tullus H (2003) Annual net nitrogen mineralization in a grey alder (Alnus incana(L.) moench) plantation on abandoned agricultural land. Forest Ecology and Management 184:167-176.

van der Wal A, van Veen JA, Smant W, Boschker H, Bloem J, Kardol P, van der Putten WH, Boer $\mathrm{W}$ de (2006) Fungal biomass development in a chronosequence of land abandonment. Soil Biology \& Biochemistry 38:51-60.

Walker LR, Chapin FS (1986) Physiological controls over seedling growth in primary succession on an Alaskan flood plain. Ecology 67:1508-1523.

Yannikos N, Leinweber P, Helgason BL, Baum C, Walley FL, van Rees K (2014) Impact of Populus trees on the composition of organic matter and the soil microbial community in Orthic Gray Luvisols in Saskatchewan (Canada). Soil Biology \& Biochemistry 70:5-11.

Zeller V, Bardgett RD, Tappeiner U (2001) Site and management effects on soil microbial properties of subalpine meadows: a study of land abandonment along a north-south gradient in the European Alps. Soil Biology and Biochemistry 33:639-649. doi:10.1016/S00380717(00)00208-X.

Zelles L (1997) Phospholipid fatty acid profiles in selected members of soil microbial communities. Chemosphere 35:275-294. doi:10.1016/s0045-6535(97)00155-0. 


\section{Chapter 5 Article III Effects of afforestation on enzyme activities in soil}

Anna Gunina ${ }^{\mathrm{a}, \mathrm{b}}$, Kristina Syundyukova ${ }^{\mathrm{c}}$, Andrew R. Smith ${ }^{\mathrm{a}}$, Davey Jones ${ }^{\mathrm{a}}$ and Yakov Kuzyakov ${ }^{\mathrm{b}}$

${ }^{a}$ School of Environment, Natural Resources and Geography, Bangor University, Bangor, Gwynedd, LL57 2UW, UK

${ }^{\mathrm{b}}$ Department of Agricultural Soil Science, Georg-August University of Göttingen, Göttingen, 37077, Germany;

${ }^{\mathrm{c}}$ Department of Organic Chemistry, Tula State University, Tula, 300012, Russian Federation

\section{Unpublished manuscript}

Author contributions: Anna Gunina prepared the manuscript.

All other authors contributed to the final version of manuscript.

Key words: Microbial activities, Cycles of carbon, nitrogen and hosphorus, Afforestation 


\section{Abstract}

Afforestation affects soil properties and processes, microbial community structure and increase limitation of carbon $(\mathrm{C})$, nitrogen $(\mathrm{N})$ and phosphorus $(\mathrm{P})$ in soils when compared to typical agricultural land use. Tree species specific changes of soil conditions can affect microbial functioning, which in turn regulate the activity of extracellular enzymes. We used the BangorDiverse afforestation experiment comprised of pure and mixed species stands to: (i) estimate how afforestation will modulate activities of enzymes responsible for $\mathrm{C}, \mathrm{N}$ and $\mathrm{P}$ cycling in soil; and (ii) explore the effects of trees with contrasting functional traits (early primary vs late succession species, and N-fixing vs non-N-fixing species) on enzyme kinetics. Soil $(0-10 \mathrm{~cm})$ was samples from monocultures of alder, birch, beech, and oak, two species mixtures (alder+beech, alder+oak, birch+beech and birch+oak) and three species mixtures (alder+birch+oak and alder+birch+beech), and compared to an agricultural field as a control. Samples were analyzed for $\beta$-glucosidase (BG) and $\beta$-xylosidase (Xyl) (C-cycle), $\beta$-N-acetylglucosaminidase (NAG) and leucine aminopeptidase (LAP) (N-cycle) and acid phosphatase (AP) (P-cycle) and the potential activity $\left(\mathrm{V}_{\max }\right)$ and substrate affinity $\left(\mathrm{K}_{\mathrm{m}}\right)$ were calculated. $\mathrm{V}_{\max }$ of LAP and BG decreased by afforestation between 1.5 and 6.0 times compared to the control. $\mathrm{V}_{\max }$ of BG and LAP correlated well with $\mathrm{pH}$. Activities of NAG, Xyl and AP remained constant after afforestation. In contrast, $\mathrm{K}_{\mathrm{m}}$ values reacted differently: $\mathrm{K}_{\mathrm{m}}$ of $\mathrm{BG}$ were the lowest (means had the highest affinity) among other enzymes and remained constant by afforestation, reflecting the stability of enzyme composition. Affinities of other enzymes increased, showing a shift in soil microbial community to K-strategies adapted to lower $\mathrm{N}$ and $\mathrm{P}$ availability. Thus, even afforestation reduced enzyme activities, their efficiencies increased. $V_{\max }$ values were tree species dependent if compared only forest plots: $V_{\max }$ of NAG, Xyl and AP were maximal in soils developed under the two species mixture with birch and, even, exceed the expected activity levels (means $V_{\max }$ values in mixed forests were expected to be mean of $\mathrm{V}_{\max }$ under monoculture forests). This shows the synergistic effect of late successional species (oak and beech) growing together with early primary species (birch) and nutrients limitation in young forests. In contrast, alder decreased activities of AP in two or three species mixed forests, or activities of LAP and NAG were close to expected. This shows that the presence of N-fixing species supplies microorganisms with sufficient amount of available nutrients, which suppress enzymes functioning. Thus, the activity of extracellular enzymes in afforestated soils is determined by species composition, and the response depends on enzyme group. 


\section{Introduction}

Forest establishment strongly influences the quality and quantity of above- and below-ground organic matter inputs that can alter soil microbial community structure and soil properties through changes in carbon $(\mathrm{C})$ and nitrogen $(\mathrm{N})$ content, and a decrease in $\mathrm{pH}$. These factors, in turn, impact upon $\mathrm{C}, \mathrm{N}$ and phosphorus $(\mathrm{P})$ cycling in the afforested soils that can accelerate element turnover. An increased input of $\mathrm{C}$ to soil and a higher demand for nutrients by plants also affects the function of soil microbial communities through their utilization of organic polymers that can be estimated by the activity of extracellular enzymes. Indeed, the activity of soil enzymes has been used as an indicator of soil fertility and nutrient dynamics of forest ecosystems (Lagomarsino et al., 2012; Ren et al., 2016). In a global analysis of soil enzyme in forest ecosystems Xu et al. (2017) showed that the activities of $\beta$-glucosidase (BG) and 1,4-N-acetylglucosaminidase (NAG) are higher in the temperate than tropical and subtropical forests. Conversely, the activity of acid phosphatase (AP) was shown to be highest in tropical soils due to the P deficiency of soils in that region (Xu et al., 2017). Enzyme activity reacts quickly to land use change (Bandick and Dick, 1999; Floch et al., 2009), and especially afforestation. Forest development usually stimulates the production and activity of soil enzymes in response to: (i) increased rhizodeposition and organic polymers inputs as reported for catalase, saccharase, urease and AP after conversion of agricultural land to forest (Ren et al., 2016); (ii) increased abundance of the fungal community and elevated chitinase activity; (iii) nutrient limitation (especially $\mathrm{N}$ ) due to intensive uptake of mineral $\mathrm{N}$ by growing trees (Herbert et al., 2003); (iv) absence of fertilization that intensify the mineralization of organic P ; (v) changes in soil $\mathrm{pH}$. However, in contrast, the activity of AP and BG activity has been shown to be suppressed in forest soils because of the high tannin and phenol content of coniferous and some deciduous forests species (Gonnety et al., 2013; Adamczyk et al., 2017). Nutrient inputs mediated by trees to soil may also suppress enzyme activity. For example, the availability of soil N (Gonnety et al., 2013) or the activity of P-acquisition enzymes associated with the N content in soils (Fatemi et al., 2016), which demonstrates the intrinsic link between $P$ and $N$ cycling in soils. Thus, the effects of afforestation on soil enzyme activities are not always positive and depend, not only on species identity, but also on a myriad of additional abiotic and biotic factors.

One of the strongest factor affecting the activity of soil enzymes in forests is tree identity. For example, proteolytic enzyme activity was higher for the soil under birch (Betula pendula) forest compared to pine (Pinus sylvestris) and spruce (Picea abies), as a result of high $\mathrm{C}$ mineralization under birch forest (Adamczyk et al., 2014). In contrast, BG activity was lower in soil developed 
under birch compared to pine forest, which was explained by a high content of cellulose in pine needles (Adamczyk et al., 2014); however, the activity of $\beta$-glucosaminidase and AP activities were similar in these soils. In a study of enzyme activity under beech (Fagus sylvatica) and two species of oak, (Quercus ilex) holm-oak and (Quercus cerris) turkey-oak in the mediterranean BG activity was found to be significantly lower under holm-oak, whereas o-diphenol oxidase activity was lowest under beech (Grosso et al., 2014). More recently, in a mixed species Mediterranean forest, Brunel et al. (2017) showed that holm-oakand Aleppo pine (Pinus halepensis) had no additive effects on cellulase activity, but that soil functioning depends on forest composition. Thus, data on soil enzyme activity under monoculture forest cannot be extrapolated to determine the effect of mixed species forest. Moreover, it is unclear how soil enzyme activities will be influenced by the simultaneous development of tree species with various functional traits.

The aim of this study was to determine the effect of tree species, planted in monoculture and a two and three species mixture, on the soil enzymes involved in the acquisition of $\mathrm{C}, \mathrm{N}$ and $\mathrm{P}$ during the early stages (10 years) of forest stand establishment. It was hypothesized that: (i) an increase in organic polymer input via roots and leaves would increase the activity of $\mathrm{C}$ acquisition enzymes; (ii) due to the young age of the aggrading forest, $\mathrm{N}$ is expected to be a limiting factor which will stimulate the production and activity of $\mathrm{N}$-acquisition enzymes; (iii) due to a strong connection between $\mathrm{N}$ and $\mathrm{P}$ cycles, an increase in the mineralization of organic $\mathrm{P}$ would simultaneously increase with the activity of $\mathrm{N}$-acquisition enzymes; (iv) the presence of $\mathrm{N}$-fixing species will decrease the activity of $\mathrm{N}$-acquisition enzymes when trees are grown in mixtures with non-N-fixing; and (v) AP activities in soil under late successional species will be lower than early successional species due to a higher tannin content of litter; whereas when early and late successional species are grown in mixture the suppressive effect of litter tannin content will neutralize any positive effect of the early successional species..

\section{Materials and methods}

\subsection{Study site and soil sampling}

BangorDIVERSE forest diversity experiment was established at Henfaes Research Centre, Bangor University, North Wales, UK $\left(53^{\circ} 14^{\prime} \mathrm{N}, 4^{\circ} 01^{\prime} \mathrm{W}\right)$ in 2004 and was designed to inform the afforestation of former agricultural fields with native broadleaved trees species. For a detailed description of the experiment design see Gunina et al. (2017) and Ahmed et al. (2016). In the experiment presented here the following forest plots were selected: in monoculture alder (Alnus 
glutinosa L.), birch (Betula pendula Roth), beech (Fagus sylvatica, L.) and oak (Quercus robur L.), two species mixtures of alder+beech, alder+oak, birch+beech, birch+oak, and three species mixtures of alder+birch+beech and alder+birch+oak. As a control soil an agricultural field adjacent to the BangorDIVERSE experiment was chosen because of its proximity to the afforested plots and similar soil type and land use history. Soils have a fine loamy texture (Smith A.. et al., 2013) and were classified as Eutric Fluvic Cambisols (WRB 2006). For each plot four samples were collected using a hand trowel from a top 0-10 cm (without soil litter) and bulked into a single composite sample (44 samples in total from 11 plots and four replicates). Soil samples were stored frozen (-20 ${ }^{\circ} \mathrm{C}$ ) before enzyme analyses. Soil chemical and biological properties are presented in Table 1 (Gunina et al., 2017).

Table 5-1. Soil biological and chemical properties after afforestation and in the control plot. Data present mean \pm st. error, $n=4$. Letters present significant differences $(P<0.05)$ level between the treatments for each parameter separately. Significant differences were obtained by Fischer post hoc test. Table is taken from the Gunina et al. (2017).

\begin{tabular}{|c|c|c|c|c|c|c|c|c|}
\hline Plant type & Abbreviation & PLFAs (nmol g- soil) & $\mathrm{C}$ (g kg soil) & $\mathrm{N}\left(\mathrm{g} \mathrm{kg}^{-1}\right.$ soil $)$ & $\mathrm{C} / \mathrm{N}$ & $\mathrm{pH}$ & $\mathrm{NO}_{3}$ (mg kg ${ }^{-1}$ soil) & $\mathrm{NH}_{4}\left(\mathrm{mg} \mathrm{kg}^{-1}\right.$ soil $)$ \\
\hline Alder & $\mathrm{Al}$ & $605.9 \pm 36.5^{\mathrm{a}}$ & $29.97 \pm 0.9^{\text {abcd }}$ & $3.1(0.1)^{\mathrm{abc}}$ & $9.62(0.10)^{\mathrm{bcd}}$ & $5.29(0.05)^{\mathrm{bc}}$ & $2.47(0.08)^{\mathrm{abc}}$ & $0.020(0.001)^{b}$ \\
\hline Birch & $\mathrm{Bi}$ & $718.2 \pm 10.5^{\mathrm{a}}$ & $33.8 \pm 2.1^{\mathrm{ab}}$ & $3.2(0.3)^{\mathrm{abc}}$ & $10.58(0.31)^{\mathrm{a}}$ & $5.36(0.03)^{\mathrm{bc}}$ & $1.50(0.07)^{\mathrm{c}}$ & $0.012(0.003)^{\mathrm{bc}}$ \\
\hline Beech & $\mathrm{Be}$ & $297.1 \pm 24.8^{c}$ & $24.8 \pm 1.3^{d}$ & $2.5(0.2)^{\mathrm{c}}$ & $9.52(0.12)^{\mathrm{cd}}$ & $5.23(0.06)^{\mathrm{ab}}$ & $1.51(0.25)^{\mathrm{C}}$ & $0.013(0.004)^{\mathrm{abc}}$ \\
\hline Oak & Oak & $683.7 \pm 53.2^{\mathrm{a}}$ & $27.3 \pm 0.7^{\mathrm{cd}}$ & $2.9(0.03)^{b c}$ & $9.86(0.32)^{\mathrm{cd}}$ & $5.26(0.18)^{\mathrm{bc}}$ & $3.09(0.42)^{\mathrm{a}}$ & $0.025(0.009)^{\mathrm{abc}}$ \\
\hline Alder+Beech & $\mathrm{Al}+\mathrm{Be}$ & $491.4 \pm 50.6^{a b}$ & $31.5 \pm 2.0^{\mathrm{abc}}$ & $3.1(0.2)^{a b c}$ & $10.30(0.27)^{\mathrm{ab}}$ & $5.35(0.18)^{\mathrm{bc}}$ & $2.57(0.23)^{a b c}$ & $0.008(0.001)^{c}$ \\
\hline Alder+Oak & $\mathrm{Al}+\mathrm{Oak}$ & $387.4 \pm 38.5^{\mathrm{b}}$ & $35.0 \pm 2.0^{\mathrm{a}}$ & $3.5(0.04)^{a}$ & $10.11(0.36)^{\mathrm{ab}}$ & $5.05(0.05)^{\mathrm{a}}$ & $3.56(0.52)^{\mathrm{a}}$ & $0.028(0.001)^{\mathrm{a}}$ \\
\hline Birch+Beech & $\mathrm{Bi}+\mathrm{Be}$ & $511.8 \pm 68.3^{\mathrm{ab}}$ & $34.7 \pm 1.8^{\mathrm{ab}}$ & $3.2(0.2)^{\mathrm{ab}}$ & $10.50(0.06)^{\mathrm{ab}}$ & $5.38(0.07)^{\mathrm{bc}}$ & $1.43(0.17)^{\mathrm{C}}$ & $0.009(0.002)^{c}$ \\
\hline Birch+Oak & $\mathrm{Bi}+\mathrm{Oak}$ & $292.5 \pm 8.5^{b c}$ & $29.9 \pm 2.0^{\mathrm{abcd}}$ & $3.0(0.2)^{\mathrm{abc}}$ & $10.01(0.04)^{\mathrm{abcd}}$ & $5.47(0.08)^{\mathrm{c}}$ & $1.43(0.31)^{\mathrm{C}}$ & $0.009(0.002)^{c}$ \\
\hline Alder+Birch+Beech & $\mathrm{Al}+\mathrm{Bi}+\mathrm{Be}$ & $234.6 \pm 16.7^{\mathrm{c}}$ & $28.56 \pm 1.45^{\mathrm{cd}}$ & $3.1(0.2)^{\mathrm{ab}}$ & $9.56(0.20)^{d}$ & $5.40(0.08)^{\mathrm{c}}$ & $2.53(0.06)^{\mathrm{abc}}$ & $0.01(0.003)^{\mathrm{C}}$ \\
\hline Alder+Birch+Oak & $\mathrm{Al}+\mathrm{Bi}+\mathrm{Oak}$ & $370.1 \pm 85.2^{b c}$ & $31.0 \pm 0.7^{\mathrm{bc}}$ & $3.0(0.1)^{\mathrm{abc}}$ & $10.23(0.25)^{\mathrm{abc}}$ & $5.33(0.04)^{\mathrm{bc}}$ & $1.83(0.22)^{b c}$ & $0.01(0.001)^{c}$ \\
\hline Agricultural (control) & C & $283.3 \pm 10.6^{b c}$ & $28.9 \pm 0.7^{\mathrm{cd}}$ & $3.0(0.1)^{\mathrm{abc}}$ & $9.65(0.30)^{d}$ & $6.49(0.06)^{d}$ & $2.84(0.10)^{\mathrm{ab}}$ & $0.013(0.006)^{\mathrm{abc}}$ \\
\hline
\end{tabular}

\subsection{Analysis of enzyme activities in soil}

Activity of soil enzymes was measured according to Razavi et al. (2016). Before enzymatic analyses, soils were pre-incubated at $20^{\circ} \mathrm{C}$ for 10 days to ensure the microbial community was not affected by sampling. The activities of the following enzymes were determined using fluorogenic methylumbelliferone (MUF) substrate for: 4-methylumbelliferyl- $\beta$-D-glucoside (for $\beta$-glucosidase (BG) activity); 4-methylumbelliferyl- $\beta$-D-xylopyranoside (for $\beta$-xylosidase (XYL) activity); 4Methylumbelliferyl-phosphate acid (for acid phosphates (AP) activity); 4-MethylumbelliferylNacetyl- $\beta$-D-Glucosaminide (for $\beta$-N-acetylglucosaminidase (NAG) activity) and Amino-4Methylcoumarin (AMC) substrate for L-leucine-7-amino-4-methyl coumarin (for leucine aminopeptidase (LAP) activity). Briefly one gram of soil (dry equivalent) was placed into a $150 \mathrm{~mL}$ bottle and $50 \mathrm{~mL}$ of autoclaved distilled water was added. Soil was dispersed by ultrasonic 
disaggregator (40 J s ${ }^{-1}$ for $120 \mathrm{~s}$ ), and aliquots of $50 \mu 1$ were placed into 96-well microplate (Brand pureGrade, black). As a buffer $50 \mu \mathrm{l}$ of $0.1 \mathrm{M}$ 2-(N-morpholino) ethanesulfonic acid (MES) (pH 6.1) was used (for all enzymes except LAP). For LAP $50 \mu 1$ of $0.05 \mathrm{M} \alpha$ - $\alpha$ - $\alpha$-Tris(hydroxymethyl)-methylamin (TRIZMA-Base) was used. Into each vial $100 \mu$ of substrates were added at concentrations of: 0, 10, 20, 30, 40, 50, 100, $200 \mu \mathrm{mol} \mathrm{g}^{-1}$ soil. Samples were incubated in total for $120 \mathrm{~min}$ with four measurements of fluorescence (excitation $360 \mathrm{~nm}$; emission $450 \mathrm{~nm}$ ) at intervals of: 0, 30, 60 and $120 \mathrm{~min}$, to obtain the kinetics of enzymatic reactions. Calibration curves were created for pure MUF or AMC substrates at nine concentrations: 0, 10, 20, 50, 100, 200, 500, $800,1200,1500 \mathrm{pmol}^{\text {well }}{ }^{-1}$. Into each microtiter plate well $50 \mu \mathrm{l}$ of soil suspension, $30-150 \mu 1$ of buffer and 0-120 $\mu$ l of MUF or AMC were added (depending on the final concentration of MUF or AMC required in a well).

The rate of enzymatic reactions were calculated for each time and were expressed as nmol activity $\mathrm{g}^{-1}$ dry soil $\mathrm{h}^{-1}$. For the final calculation of maximal rate of enzyme catalysis = potential activity $\left(V_{\max }\right)$ and Michaelis constant $\left(K_{m}\right)$, the time interval with maximum parameters of enzyme activities was chosen (two hours, in our case).

\subsection{Calculations and Statistics}

The measured enzyme activities were plotted against substrate concentrations and the following Equation 1 was fitted to calculate $V_{\max }$ and $K_{m}$ :

$$
v=\frac{V_{\max } \cdot S}{K_{m}+S}
$$

Equation 1.

where, $v$ is the substrate-dependent rate of reaction (nmol activity $\mathrm{g}^{-1}$ dry soil $\mathrm{h}^{-1}$ ), $\mathrm{S}$ is the substrate concentration ( $\mu \mathrm{mol} \mathrm{g}{ }^{-1}$ soil $^{-1}$ ), $V_{\max }$ is the maximal velocity of enzyme catalysis (nmol MUF/AMC $\mathrm{g}^{-1} \mathrm{~h}^{-1}$ ) responsible for decomposition rates at saturating substrate concentrations and $\mathrm{K}_{\mathrm{m}}$ is a Michaelis constant $\left(\mu \mathrm{M} \mathrm{g}^{-1}\right)$ that reflects the affinity of substrates to enzymes and is numerically equal to the concentration of the substrate for half of maximal velocity. Additionally the expected $\mathrm{V}_{\max }$ for the two and three species mixtures were calculated from the $\mathrm{V}_{\max }$ of each single species contributing to the mixture determined from the monoculture stand. 


\section{Results}

\subsection{Response of enzyme activities to afforestation}

Enzyme kinetics of LAP, BG and AP for the control, birch monoculture, two and three tree species mixture are shown in Fig. 5-1. Enzyme activity decreased for all enzymes following afforestation with the selected species. The strongest reduction in enzyme activity was found in the three species mixtures.

The activity of enzymes responsible for the cellobiose hydrolysis (BG) decreased by 1.4 to 3-fold in all forest soils compared to the control, with the lowest values observed for the beech monoculture, two species mixtures with oak and three species mixtures (Fig. 5-2). Xylanase activity was six times lower than BG, however, the magnitude of response to afforestation was similar for both enzymes. The lowest enzyme activity was observed for beech grown in monoculture, whereas presence of birch increase Xyl activity in two species mixtures.

Leucine aminopeptidase activities decreased for all afforested plots. The presence of late successional species, such as beech and oak, decreased the LAP activity in both two and three species mixtures when in admixture with birch. Conversely, when oak was mixed with alder an increased LAP activity was observed. Figure 5-3 shows that a decrease in both BG and LAP activities were correlated with decreases in soil $\mathrm{pH}$ associated with afforestation. Activity of NAG in afforested soils was similar to the control soil, only for oak in monoculture was a significant decrease found. Simultaneous development of birch with beech and oak increased NAG activity in two species mixtures. In contrast, the presence of alder did not effect NAG activity in the two species mixtures.

Acid phosphatase activity decreased by two-fold for oak and beech in monoculture compared the control. When oak or beech was in a two species admixture with alder a similar twofold decrease was observed, but this effect was not observed in admixture with birch. Suppression of enzyme activity also occurred when oak or beech was in a three species mixture with alder and birch. The highest enzyme activity was observed under birch and alder monocultures, suggesting that $\mathrm{P}$ limitation could explain this response with early successional species. In contrast, birch in admixture with oak or beech increased AP activity suggesting a greater potential for mineralization of organic P. 

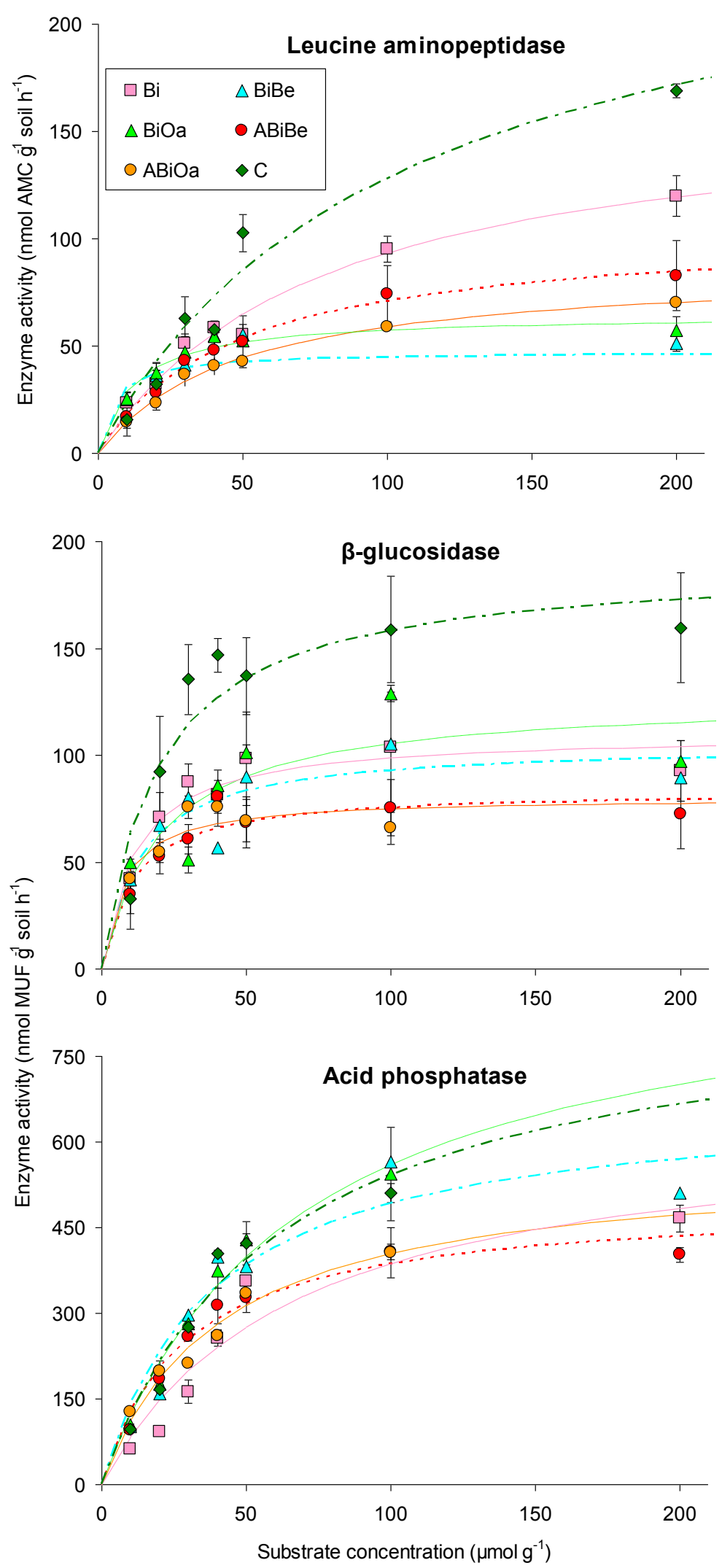

Figure 5-1. Dependence of enzyme activities from substrate concentrations in soil under pure and mix species forests. Bi - birch, BiBe - birch+beech, BiOa - birch+oak, ABiBe - alder+birch+beech, ABiOa - alder+birch+oak, $C$ - control. Values present means of 4 replications +- st.errors. 

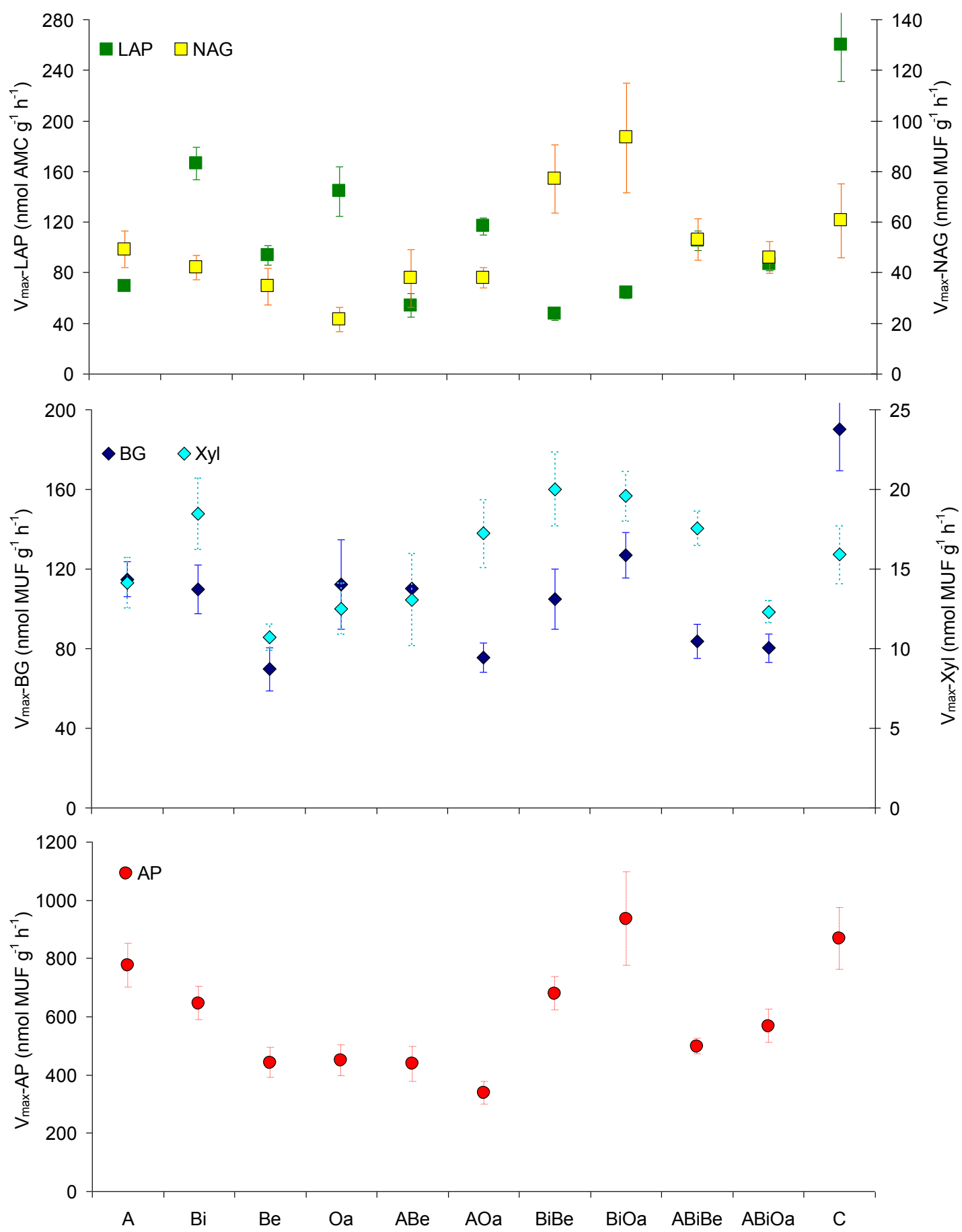

Figure 5-2. $V_{\max }$ parameter of kinetic of the enzymes responsible for $C$ ( $\beta$-glucosidase and xylanase), $N$ (Leucyl aminopeptidases and $N$-acetyl glucosaminidase) and $P$ (acids-phosphatase) cycles for the soils formed under mono-, two- and three species mixtures forests. Al (alder), Bi (birch), Be (beech), Oa (oak), ABe (alder+beech), AOa (alder+oak), BiBe (birch+beech), BiOa (birch+oak), ABiBe (alder+birch+beech), ABiOa (alder+birch+oak). Data present mean \pm st error, $n=4$. 


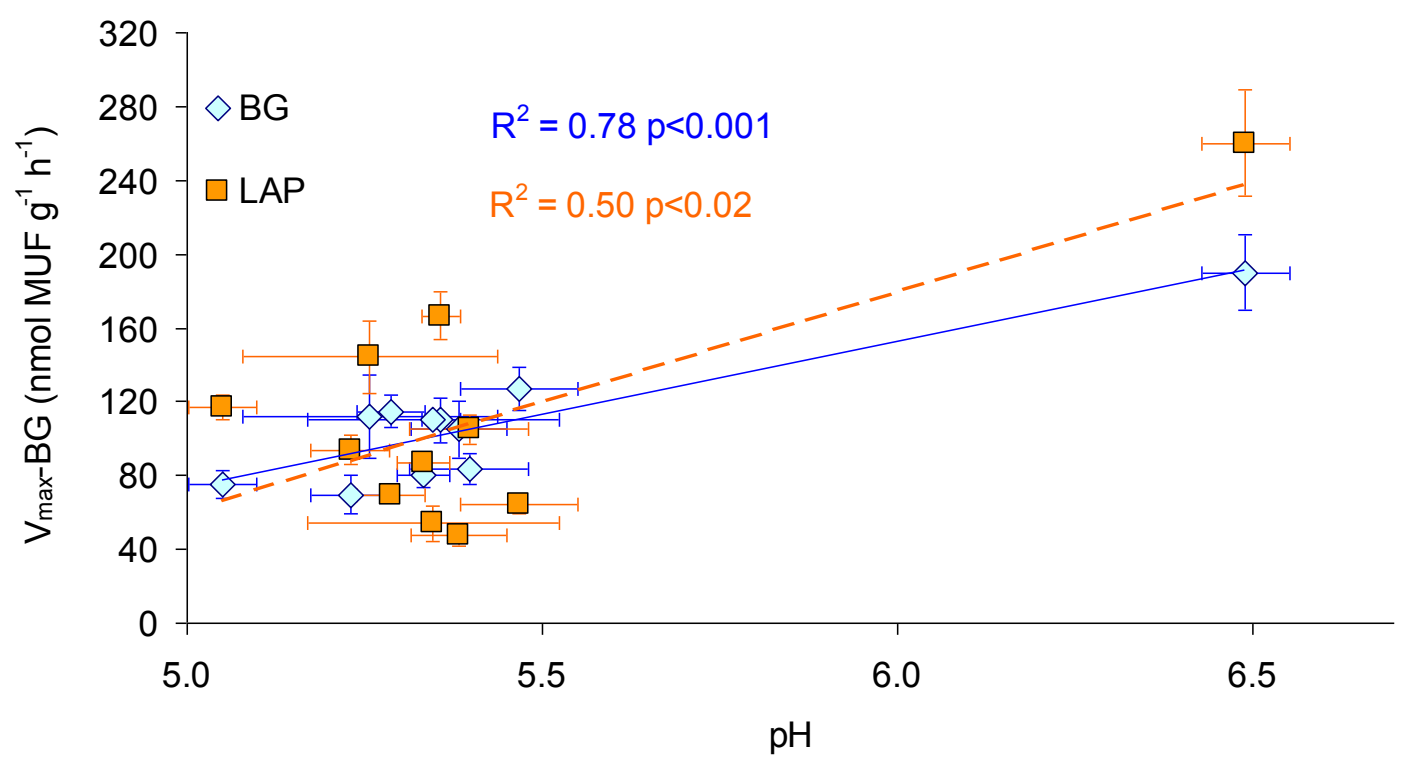

Figure 5-3. Dependence of $V_{\max }$ values of $\beta$-glucosidase $(B G)$ and leucine-aminopeptidase (LAP) from soil $\mathrm{pH}$ values. Data present mean \pm st error, $n=4$.

\subsection{Effect of forest mixtures on the expected enzyme activities}

Presence of birch in two species mixtures increased NAG activity 2-3 fold, whereas LAP activity was decreased (Fig. 5-4). In contrast, the presence of alder in two and three species mixtures resulted in the activities of NAG and LAP corresponded to the expected activity calculated from species in monoculture. Measured activities of BG correspond to expected activity in calculated from monoculture with the exception of the alder and oak two species mixture. Development of mixed species forests tended to increased xylanase activity compared with expected levels with the exception of alder and beech in a two species mixture and three species mixtures with oak. Presence of birch increased AP activity compared to expected levels in the two species mixtures, whereas presence of alder decreased AP activity. 

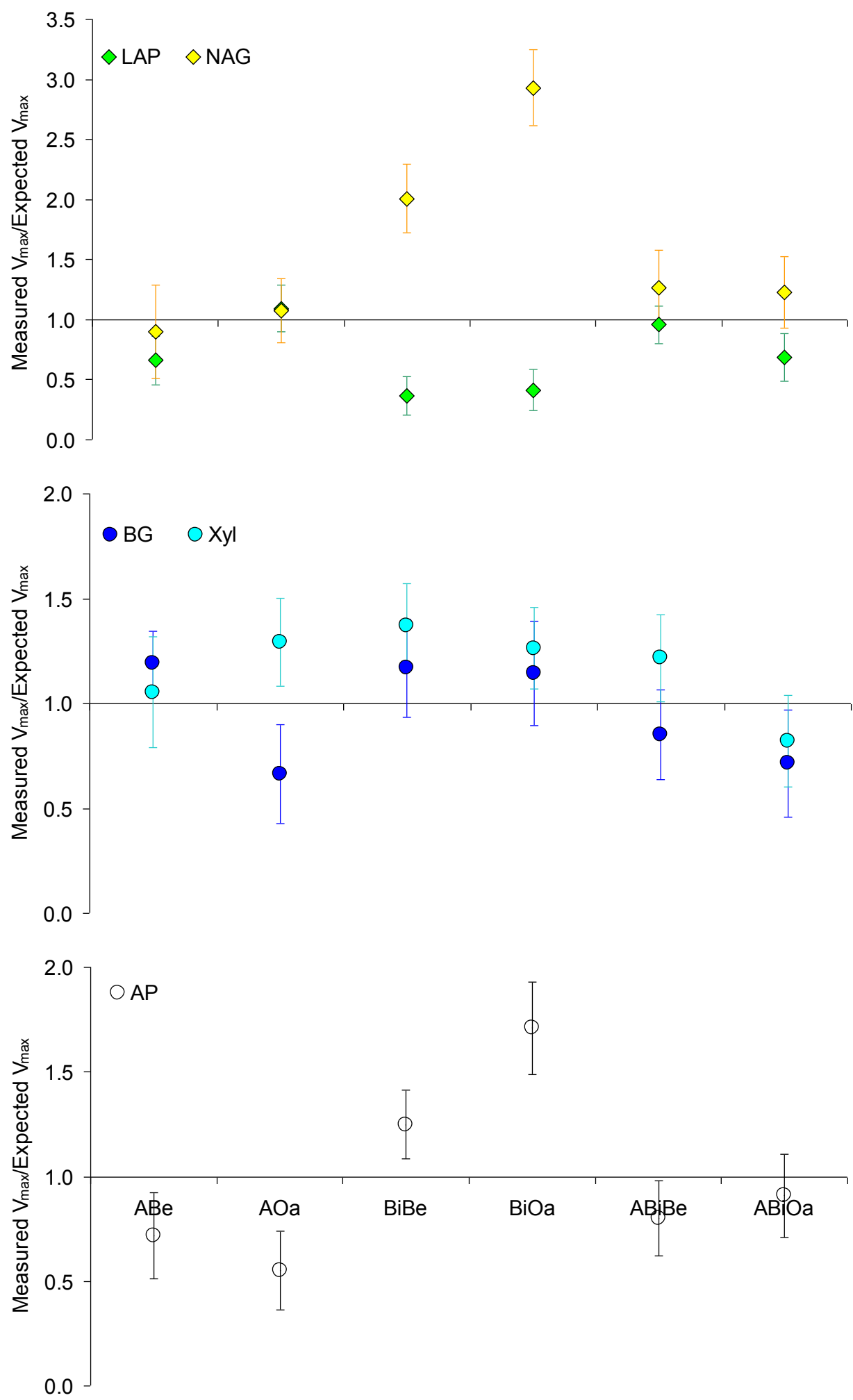

Figure 5-4. Data for the expected values of $V_{\max }$ for the two and three species mixtures. Data present mean \pm st error, $n=4$. Values are calculated assuming that $V_{\text {max }}$ values for the two or three species mixtures are means of $V_{\text {max }}$ of monocultural species. In case y-value is equal to " 1 ", the measured $V_{\max }$ is equal to expected $V_{\max }$. 


\subsection{Response of enzyme affinities to afforestation}

The response of enzyme affinities (Fig. 5-5) to afforestation varied: the highest affinities (the lowest $\mathrm{K}_{\mathrm{m}}$ values) were found for BG and Xyl, and were 2-3 fold lower for other enzymes. $\mathrm{K}_{\mathrm{m}}$ values of BG were not affected by afforestation, whereas affinities of Xyl increased for all forests except birch in monoculture and the birch and beech mixture. Affinities of LAP increased for all afforested plots with the exception of birch and oak, with the highest effect found for two species mixtures in admixture with birch. For NAG a strong decrease of $\mathrm{K}_{\mathrm{m}}$ values was found for the oak monoculture, whereas NAG affinity was not affected by the other species. Affinities of AP increased for the two species mixtures in admixture with alder, but were less affected by other forest types. Thus, afforestation does not necessarily increase enzyme affinities to substrate, which shows a variable response of enzyme systems to changed environmental conditions. 

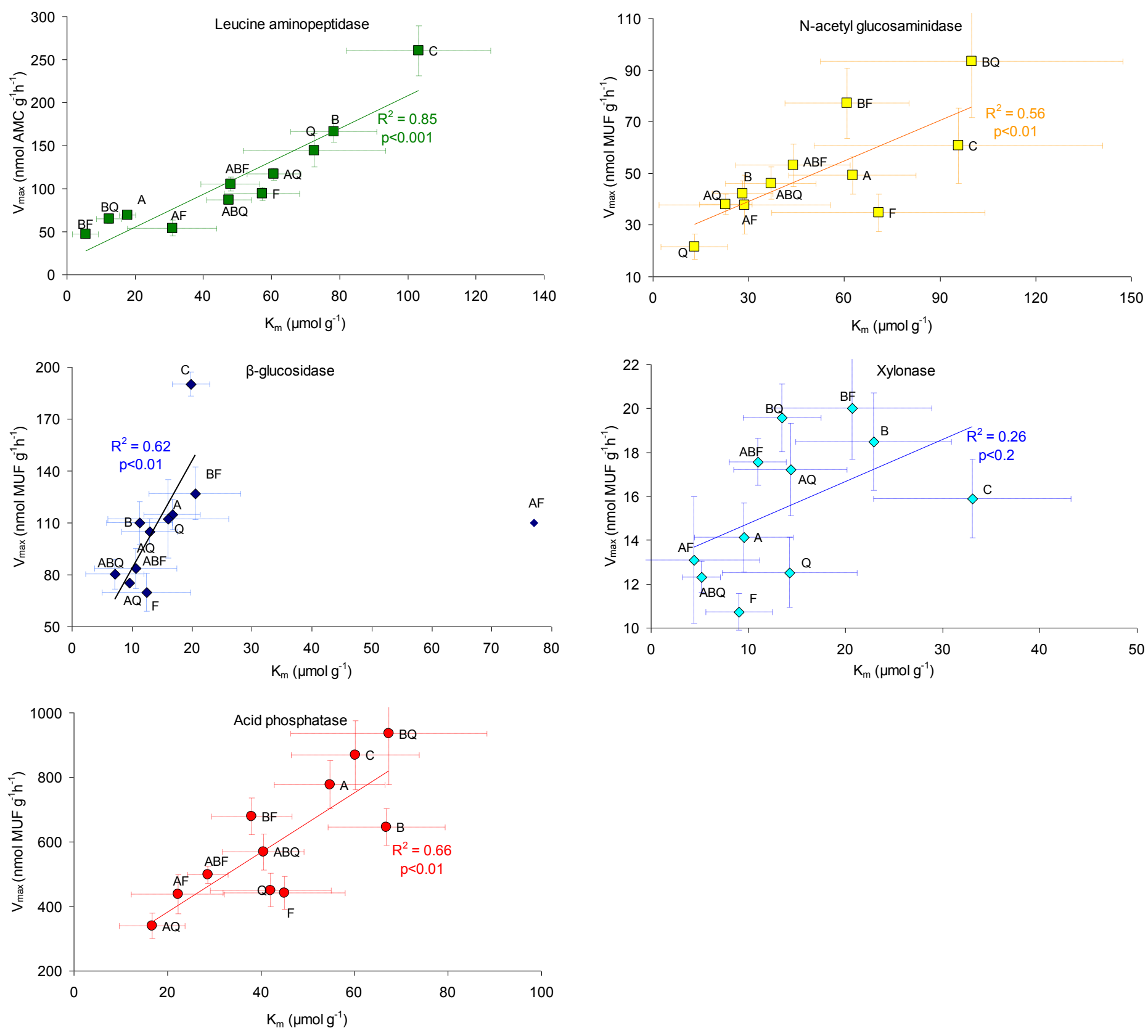

Figure 5-5. $K_{m}$ and $V_{\text {max }}$ parameters of the enzymes responsible for $C$ ( $\beta$-glucosidase and xylanase), $N$ (Leucyl aminopeptidases and $N$-acetyl glucosaminidase) and $P$ (acids-phosphatase) cycles for the soils formed under mono-, two- and three species mixtures forests. Regression line for $B G$ was done without AF. Al (alder), Bi (birch), Be (beech), Oa (oak), ABe (alder+beech), AOa (alder+oak), BiBe (birch+beech), BiOa (birch+oak), ABiBe (alder+birch+beech), ABiOa (alder+birch+oak). Data present mean \pm st error, $n=4$. 


\section{Discussion}

\subsection{Changes of soil properties and decrease of enzyme $V_{\max }$ after afforestation}

Development of forests on former arable land increases C inputs into the soil (Jandl et al., 2007). As shown by Gunina et al. (2017) in previous work at BangorDiverse soil, total C and N content were increased by up to $20 \%$ after 10 years of afforestation when compared to the agricultural control soil (Table 5-1). Microbial community structure was altered through a strong increase of fungi. Additionally, microbial community composition changes were observed for both monoculture and mixed species forests (Gunina et al., 2017).

Usually, increased input of rhizodeposition and especially above- and below-ground litter affects the production and activities of exoenzymes by microorganisms that are responsible for the decomposition of organic polymers (Gispert et al., 2013). However, as identified in our results, the activity of BG (responsible for degradation of $\beta$-D-glucosides and oligosaccharides) decreased after afforestation for all plots (Fig. 5-2) and the activity of LAP (responsible for hydrolysis of leucine residues in peptides and proteins (Blagodatskaya and Kuzyakov, 2008) also decreased in most of the afforested soils compared to the control. Activity of both enzymes was positively correlated with $\mathrm{pH}$ changes by afforestation, which is in agreement with a study of Burns et al. (2013), where a positive effect of $\mathrm{pH}$ on the activity of LAP was reported. However, effect of $\mathrm{pH}$ on the enzyme activity is not always found and depends on the plant community type (Štursová and Baldrian, 2011)

An absence of an effect of total soil $\mathrm{C}$ or $\mathrm{N}$ on $\mathrm{V}_{\max }$ is in congruent with enzyme activities having non-linear dependency on the nutrient availability in soils (Xu et al., 2017) and can be also affected by other factors (Adamczyk et al., 2017).

Activity of BG in the forest soils can be suppressed by the presence of tannins in the tree litter (Joanisse et al., 2007), which generally decrease enzyme activities (Adamczyk et al., 2017). Upregulation of BG activity in arable land can be a result of the removal of crop residues during annual harvesting which requires maintaining monomer production for microorganisms.

The BG affinities were similar to cropland after afforestation (Fig. 5-3), showing the stability of microbial functions regarding decomposition of oligosaccharides. Nevertheless, increase of LAP enzyme efficiency, indicated by a up to 10 fold $\mathrm{K}_{\mathrm{m}}$, following afforestation shows a shift towards K-strategy. The K-microorganisms decompose organic polymers found in forest detritus more efficiently compared to r-strategy microorganisms (Loeppmann et al., 2016). 


\subsection{Forest composition and $N$ limitation}

Nitrogen accumulated as amino sugars within microbial residues in soil has a concentration of around 400-800 $\mathrm{g} \mathrm{kg}^{-1}$ soil $\mathrm{N}$ (Amelung et al., 2001), and is one of the main $\mathrm{N}$ sources for mineralization and utilization by microorganisms. The decrease of NAG activity, which is responsible for mineralization of organic $\mathrm{N}$ contained within chitin from the cell walls of fungi and exoskeleton of arthropods, was observed in the beech monoculture, whereas for all other tree species and mixtures NAG was not affected. The presence of birch in the two species mixtures in admixture with oak and beech increased NAG activity compared with oak and beech in monoculture. This suggests that birch strongly promotes the development of mycorrhizal and saprophytic fungi (Gunina et al., 2017). Measured NAG activity was higher than expected (Fig. 5-4) for the two species mixtures with birch indicating that enzyme production was stimulated when birch is in admixture with late successional species, e.g oak and beech. Substrate affinity of NAG slightly increased with afforestation, showing that microorganisms in forest soils utilize $\mathrm{N}$ from microbial residues more efficiently as compared to cropland.

The lowest LAP activity was found in soils under alder that could be explained by the Nfixing trait of this species as elevated $\mathrm{N}$ inputs reduce the necessity for microorganisms to mediate $\mathrm{N}$ mineralization (Xu et al., 2017). In contrast, higher LAP activity was found in soils under birch and oak forests suggesting a stronger $\mathrm{N}$ demand and increased $\mathrm{N}$ limitation without $\mathrm{N}$ fertilization or $\mathrm{N}$ deficiency in these soils that requires increased mineralization of organic $\mathrm{N}$. These results are in agreement with often reported $\mathrm{N}$ limitation observed in young aggrading deciduous forests (Ren et al., 2016). Measured LAP activities for the two species mixtures in admixture with birch were lower than expected showing an opposite trend with NAG activity. Thus, development of birch forest stands in admixture with late successional species promotes mineralization of $\mathrm{N}$ from cell wall residues rather than from proteins. In contrast, when alder is present in the stand, the estimated and measured $\mathrm{V}_{\max }$ values were almost identical suggesting that when grown in mixture alder provides a sufficient amount of available $\mathrm{N}$ for microbial demand.

Thus, the effect of forest species composition on the activity of NAG is tree species specific, and synergetic effects can be found when two species mixtures include birch. In contrast, LAP activity was low suggesting adaptation of enzyme systems to a particular forest type. 


\subsection{Forest composition and C cycle}

In contrast to BG, activity of Xyl was mainly unaffected by afforestation (only trends in activity increase were found) (Fig. 5-2). Xylanase is an enzyme which breaks down hemicellulose (Blagodatskaya and Kuzyakov, 2008), and its activity depends on quantity and quality of substrates (Snajdr et al., 2013). Thus, an increase of hemicellulose input with forest litter could have stimulated Xyl production. Tree species identify differentially affected Xyl activity: lower values were found for in beech and oak monocultures, whereas higher values were reported for birch in monoculture, two species mixtures in admixture with birch, and three species mixture in admixture with beech. The low $\mathrm{V}_{\max }$ values for beech and oak are linked to lower quality litter as the $\mathrm{C}: \mathrm{N}$ ratio of the litter was found to be 72 and 39 for beech and oak, respectively (Gunina et al., 2017), which usually slows down decomposition rate. In contrast, the presence of easily decomposable birch litter with a $\mathrm{C}$ : $\mathrm{N}$ ratio of 32 stimulated Xyl production and activity in the soils under both the two and three species mixtures. Also, the expected $V_{\max }$ were lower compared to actual ones for two and three species mixture forests (excluding alder+beech and alder+birch+oak) showing the stimulation of Xyl production when late successional species (oak and beech) grow together with early primary species (alder and birch). However, for the alder, alder+beech, alder+birch+oak the $\mathrm{K}_{\mathrm{m}}$ values decreased with afforestation reflecting shift in microbial community to K-strategists and increase of enzyme efficiency under substrate limitation (Loeppmann et al., 2016). Thus, Xyl activity was also tree species specific, showing either constant level (in the presence of birch), or increase in efficiency in presence of alder, due to changes in microbial community strategies and $\mathrm{C} / \mathrm{N}$ ratio of litter.

\subsection{Forest composition and P limitation}

Availability of $\mathrm{P}$ often limits the productivity of terrestrial ecosystems, and utilization of mineral $\mathrm{P}$ results in a significant portion (up to $90 \%$ ) of $\mathrm{P}$ being in organic complexes (Margalef et al., 2017). Thus, a presence of available of $P$ in soils suggests efficient enzymatic mining by microorganisms of $\mathrm{P}$ from SOM or plant detritus. Even if AP was suppressed by afforestation, the differences between forests were found, showing various $\mathrm{P}$ availability depending on forest type. Higher AP activity was observed for the birch compared with late successional species (beech and oak) and also for the two species mixtures with birch. This was in accordance with high activities of $\mathrm{N}$ acquisition enzymes - LAP and NAG in these soils, which points to the increasing demands of trees and microorganisms for $\mathrm{P}$, where the soil $\mathrm{N}$ content is high (Margalef et al., 2017), and there is 
active immobilization of $\mathrm{P}$ by microorganisms (Nannipieri et al., 2011). In contrast, simultaneous development of alder with late successional tree species (beech and oak) decreased AP activity to a level even lower than expected, with simultaneous increase of enzyme affinities. This reflects changes in AP enzyme system with afforestation, and more efficient enzyme systems.

\section{Conclusions}

Development of forests with tree species possessing contrasting functional traits (i.e. N-fixers, mycorrhization, litter quality) in monoculture and mixtures can differentially affect enzyme activities in soils. Enzymes linked to $\mathrm{C}$ cycling (BG) decreased in response to afforestation, whilst the enzyme affinity remained unchanged. Decrease of soil $\mathrm{pH}$ was a strongly correlated with decrease of BG activity, but additional factors such as a presence of tannins in the litter can suppress BG activity. In contrast, the increase of Xyl activity or its constant values compared to agricultural control plot were connected with high substrate inputs with the forest litter rich in hemicellulose, and partly confirm the first hypothesis.

Activities of LAP decreased by afforestation for 1.5 - 6 times, whereas LAP affinity increased, showing the shift in microbial community to K-strategies with more efficient enzyme systems. Simultaneous development of oak or beech in two species mixtures with birch increased NAG activity compared to other species, showing high $\mathrm{N}$ limitation in these soils. In contrast, the presence of alder did not affect much LAP or NAG activities in two or three species mixtures, showing that $\mathrm{N}$-fixing trees supply microorganisms with sufficient available $\mathrm{N}$, even when growing in mixtures.

High AP activity was found under monocultural alder and birch forests, as well as under two species mixtures with birch, reflecting the same trend as for $\mathrm{N}$-acquisition enzymes. This shows the link between enzymes responsible for $\mathrm{N}$ and P-cycling in young forest soils. Thus, microbial enzyme systems react differently to afforestation with species having contrast functional traits, even for enzymes responsible for one nutrient. The maximal activities between the forests were found for the sites, where birch developed simultaneously with late successional species, showing synergistic effects on soil microorganisms. Thus, these results can be used for the effective forest planting to ensure sufficient input of nutrients to the soil during trees growth. 


\section{Acknowledgements}

Anna Gunina was funded by the Education, Audiovisual and Culture Executive Agency (EACEA) of the European Commission under Erasmus Mundus Action 1 through individual Doctoral fellowships as part of the ErasmusMundus Joint Doctoral Programme "Forests and Nature for Society" (FONASO). The authors acknowledge the financial support provided by the Welsh Government and Higher Education Funding Council for Wales through the Sêr Cymru National Research Network for Low Carbon, Energy and Environment. Thanks are also given to Dr. Bahar Razavi, who consulted regarding the enzyme activities measurement and inspirited to finish this article.

\section{References}

Adamczyk, B., Karonen, M., Adamczyk, S., Engström, M.T., Laakso, T., Saranpää, P., Kitunen, V., Smolander, A., Simon, J., 2017. Tannins can slow-down but also speed-up soil enzymatic activity in boreal forest. Soil Biol. Biochem. 107, 60-67. doi:10.1016/j.soilbio.2016.12.027

Adamczyk, B., Kilpeläinen, P., Kitunen, V., Smolander, A., 2014. Potential activities of enzymes involved in $\mathrm{N}, \mathrm{C}, \mathrm{P}$ and $\mathrm{S}$ cycling in boreal forest soil under different tree species.

Pedobiologia 57, 97-102. doi:10.1016/j.pedobi.2013.12.003

Ahmed, I.U., Smith, A.R., Jones, D.L., Godbold, D.L., 2016. Tree species identity influences the vertical distribution of labile and recalcitrant carbon in a temperate deciduous forest soil. For. Ecol. Manag. 359, 352-360. doi:10.1016/j.foreco.2015.07.018

Amelung, W., Kimble, J.M., Samson-Liebig, S., Follett, R.F., 2001. Restoration of microbial residues in soils of the Conservation Reserve Program. Soil Sci. Soc. Am. J. 65, 1704-1709.

Bandick, A.K., Dick, R.P., 1999. Field management effects on soil enzyme activities. Soil Biol. Biochem. 31, 1471-1479. doi:10.1016/S0038-0717(99)00051-6

Blagodatskaya, E., Kuzyakov, Y., 2008. Mechanisms of real and apparent priming effects and their dependence on soil microbial biomass and community structure: critical review. Biol. Fertil. Soils 45, 115-131. doi:10.1007/s00374-008-0334-y

Brunel, C., Gros, R., Ziarelli, F., Farnet Da Silva, A.M., 2017. Additive or non-additive effect of mixing oak in pine stands on soil properties depends on the tree species in Mediterranean forests. Sci. Total Environ. 590-591, 676-685. doi:10.1016/j.scitotenv.2017.03.023

Burns, R.G., DeForest, J.L., Marxsen, J., Sinsabaugh, R.L., Stromberger, M.E., Wallenstein, M.D., Weintraub, M.N., Zoppini, A., 2013. Soil enzymes in a changing environment: Current knowledge and future directions. Soil Biol. Biochem. 58, 216-234. doi:10.1016/j.soilbio.2012.11.009

Fatemi, F.R., Fernandez, I.J., Simon, K.S., Dail, D.B., 2016. Nitrogen and phosphorus regulation of soil enzyme activities in acid forest soils. Soil Biol. Biochem. 98, 171-179. doi:10.1016/j.soilbio.2016.02.017

Floch, C., Capowiez, Y., Criquet, S., 2009. Enzyme activities in apple orchard agroecosystems: How are they affected by management strategy and soil properties. Soil Biol. Biochem. 41, 61-68. doi:10.1016/j.soilbio.2008.09.018 
Gispert, M., Emran, M., Pardini, G., Doni, S., Ceccanti, B., 2013. The impact of land management and abandonment on soil enzymatic activity, glomalin content and aggregate stability. Geoderma 202, 51-61. doi:10.1016/j.geoderma.2013.03.012

Grosso, F., Temussi, F., De Nicola, F., 2014. Water-extractable organic matter and enzyme activity in three forest soils of the Mediterranean area. Eur. J. Soil Biol. 64, 15-22. doi:10.1016/j.ejsobi.2014.06.003

Gunina, A., Smith, A.R., Godbold, D.L., Jones, D.L., Kuzyakov, Y., 2017. Response of soil microbial community to afforestation with pure and mixed species. Plant Soil 412, 357-368. doi:10.1007/s11104-016-3073-0

Herbert, D.A., Williams, M., Rastetter, E.B., 2003. A model analysis of N and P limitation on carbon accumulation in Amazonian secondary forest after alternate land-use abandonment. Biogeochemistry 65, 121-150. doi:10.1023/A:1026020210887

Jandl, R., Lindner, M., Vesterdal, L., Bauwens, B., Baritz, R., Hagedorn, F., Johnson, D.W., Minkkinen, K., Byrne, K.A., 2007. How strongly can forest management influence soil carbon sequestration? Geoderma 137, 253-268. doi:10.1016/j.geoderma.2006.09.003

Joanisse, G.D., Bradley, R.L., Preston, C.M., Munson, A.D., 2007. Soil enzyme inhibition by condensed litter tannins may drive ecosystem structure and processes: the case of Kalmia angustifolia. New Phytol. 175, 535-546. doi:10.1111/j.1469-8137.2007.02113.x

Lagomarsino, A., Grego, S., Kandeler, E., 2012. Soil organic carbon distribution drives microbial activity and functional diversity in particle and aggregate-size fractions. Pedobiologia 55, 101-110. doi:10.1016/j.pedobi.2011.12.002

Loeppmann, S., Blagodatskaya, E., Pausch, J., Kuzyakov, Y., 2016. Substrate quality affects kinetics and catalytic efficiency of exo-enzymes in rhizosphere and detritusphere. Soil Biol. Biochem. 92, 111-118. doi:10.1016/j.soilbio.2015.09.020

Margalef, O., Sardans, J., Fernández-Martínez, M., Molowny-Horas, R., Janssens, I.A., Ciais, P., Goll, D., Richter, A., Obersteiner, M., Asensio, D., Peñuelas, J., 2017. Global patterns of phosphatase activity in natural soils. Sci. Rep. 7, 1337. doi:10.1038/s41598-017-01418-8

Nannipieri, P., Giagnoni, L., Landi, L., Renella, G., 2011. Role of Phosphatase Enzymes in Soil, in: Phosphorus in Action, Soil Biology. Springer, Berlin, Heidelberg, pp. 215-243. doi:10.1007/978-3-642-15271-9_9

Razavi, B.S., Blagodatskaya, E., Kuzyakov, Y., 2016. Temperature selects for static soil enzyme systems to maintain high catalytic efficiency. Soil Biol. Biochem. 97, 15-22. doi:10.1016/j.soilbio.2016.02.018

Ren, C., Kang, D., Wu, J. ping, Zhao, F., Yang, G., Han, X., Feng, Y., Ren, G., 2016. Temporal variation in soil enzyme activities after afforestation in the Loess Plateau, China. Geoderma 282, 103-111. doi:10.1016/j.geoderma.2016.07.018

Smith A.., Lukac M., Hood R., Healey J.R., Miglietta F., Godbold D.L., 2013. Elevated CO2 enrichment induces a differential biomass response in a mixed species temperate forest plantation. New Phytol. 198, 156-168.

Snajdr, J., Dobiásová, P., Urbanová, M., Petránková, M., Cajthaml, T., Frouz, J., Baldrian, P., 2013. Dominant trees affect microbial community composition and activity in post-mining afforested soils. Soil Biol. Biochem. 56, 105-115.

Štursová, M., Baldrian, P., 2011. Effects of soil properties and management on the activity of soil organic matter transforming enzymes and the quantification of soil-bound and free activity. Plant Soil 338, 99-110. doi:10.1007/s11104-010-0296-3

T. Gonnety, J., L. Assémien, E.F., M. Guéi, A., A. N'Dri, A., Djina, Y., W. Koné, A., E. Tondoh, J., 2013. Effect of land-use types on soil enzymatic activities and chemical properties in semi-deciduous forest areas of Central-West Côte d'Ivoire. BASE. 
Xu, Z., Yu, G., Zhang, X., He, N., Wang, Q., Wang, S., Wang, R., Zhao, N., Jia, Y., Wang, C., 2017. Soil enzyme activity and stoichiometry in forest ecosystems along the North-South Transect in eastern China (NSTEC). Soil Biol. Biochem. 104, 152-163. doi:10.1016/j.soilbio.2016.10.020 


\section{Chapter 6 Article IV Microbial nitrogen cycling gene abundance does not reflect nitrogen processing rates in forest soils}

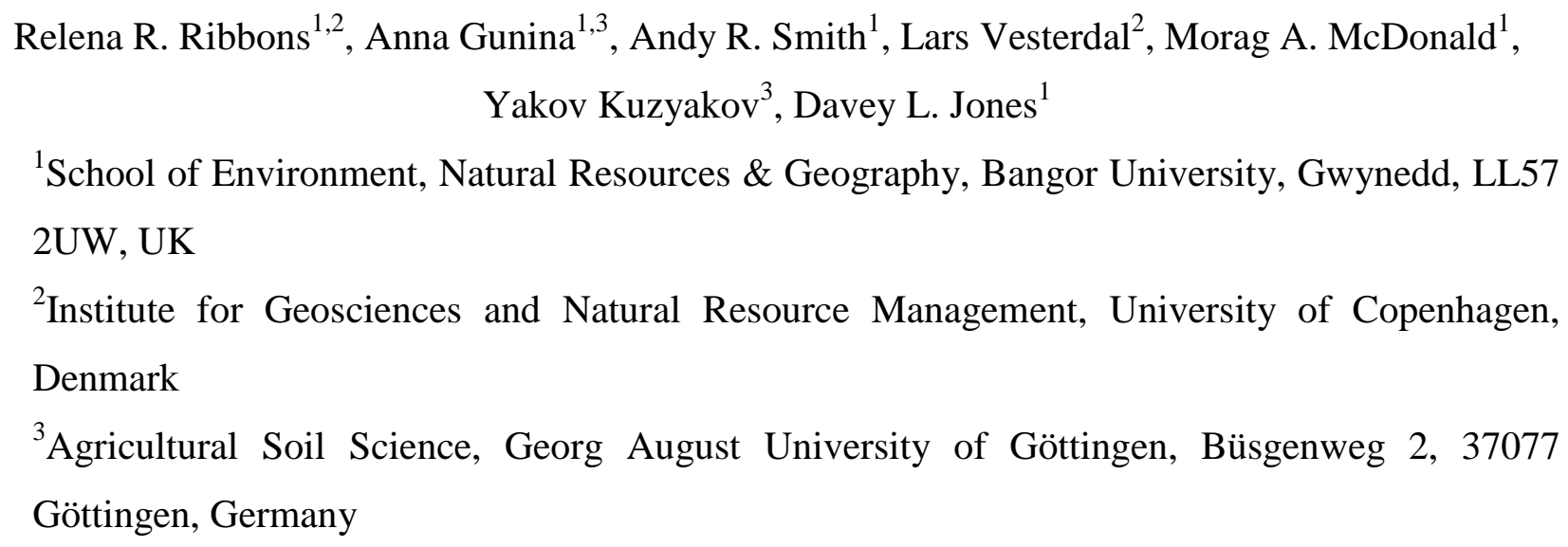

\section{Unpublished manuscript}

Author contributions: Anna Gunina and Relena R. Ribbons contributed equally to this work. All other authors contributed to the final version of manuscript.

Keywords: Forest biodiversity; Nitrogen cycling; Functional genes; Microbial community structure; Nutrient dynamics 


\begin{abstract}
Increased forest biodiversity can enhance ecosystem resilience as well as promoting the delivery of a wide range of ecosystem services, including nutrient cycling. The effects of forest biodiversity and tree species mixtures on soil microbial communities and nitrogen $(\mathrm{N})$ cycling were explored in a Eutric Cambisol underneath an 11-year-old forest diversity experiment (BangorDiverse, UK). Within this experiment, soil samples from the $0-10 \mathrm{~cm}$ mineral horizon were sampled under monocultures of alder (Alnus glutinosa), birch (Betula pendula) and beech (Fagus sylvatica), and the di- and tri-mixes of these species. The soil microbial community was studied by qPCR for bacterial $16 S$, fungal ITS, and functional genes associated with $\mathrm{N}$ cycling. Net $\mathrm{N}$ transformation process rates (gross and net nitrification, and ammonification) were measured by aerobic and anaerobic incubation methods to explore the links between $\mathrm{N}$ process rates and soil microbial communities. We found that the biomass of fungi and bacteria as well as $\mathrm{N}$ cycling gene abundance, including markers for denitrifying bacteria (nirK and nirS), and ammonia-oxidizing archaea (AOA) and bacteria $(\mathrm{AOB})$, were unaffected by the presence of different tree species. In contrast, net nitrification rate was the highest under alder and lowest for beech and alder+beech forests. Ammonification rates were higher for birch and alder, than for the other forest types. The presence of beech or birch in the alder forest decreased gross nitrification rates by 1.4 times. In summary, even though no effect of tree species, or their mixtures, was found on $\mathrm{N}$ cycling gene abundance 11 years after forest establishment, differences in $\mathrm{N}$ processing rates could already be detected. Thus, both parameters should be taken into account during the estimation the effect of afforestation of $\mathrm{N}$ cycling.
\end{abstract}




\section{Introduction}

Strategies to promote forest biodiversity and replace monocultures are gaining popularity worldwide (Verheyen et al., 2016). Enhanced biodiversity can provide a plethora of benefits from enhanced ecosystem stability and resilience to disturbances (Holling, 1973; Loreau and de Mazancourt, 2013), e.g. in connection with species-specific pests and pathogens (Haase et al., 2015; Mellec et al., 2009). Tree species affect below-ground processes via organic matter inputs from above- (Hobbie, 1992; Jewell et al., 2017), and below-ground (Godbold et al., 2006), altering soil microbial community structure and functions (Aponte et al., 2013; Hackl et al., 2005; Purahong et al., 2016), and cascading effects on nutrient cycling (Ribbons et al., 2016). The loss of tree species, or the arrival of invasive tree species are known to negatively impact on a range of ecosystem processes including soil nutrient cycling (Hackl et al., 2005).

However, the question remains as to how species mixtures, or increasing tree species diversity will affect soil carbon $(\mathrm{C})$ and nitrogen $(\mathrm{N})$ cycling and the microbial communities that control these processes. Determining the effects of tree species diversity of mixed forests through the use of controlled factorial experiments, is an important platform for the development of forest management strategies (Verheyen et al., 2016). Previous studies have reported that single tree species do influence $\mathrm{N}$ cycling rates and the soil microbial community associated with that ecosystem function (Levy-Booth et al., 2014; Ribbons et al., 2016). In this study, we aimed to determine if two- and three-species mixtures alter soil microbial communities and ecosystem processes related to $\mathrm{N}$ turnover in soil compared to single species stands of the same tree species. We aimed to address the following research questions:

1. Does tree species diversity influence soil microbial community composition?

2. Does increased tree species diversity alter $\mathrm{N}$ processes?

3. Do tree species with contrasting functional leaf traits (C:N ratios, decomposition rates) alter the abundance of functional $\mathrm{N}$ cycling genes, as assessed by denitrifying bacteria and ammonia-oxidizing bacteria and archaea?

We hypothesized that the functional genes of soil microbes involved in $\mathrm{N}$ cycling processes would increase with increasing tree species diversity. Given the contrasting functional traits of the three tree species in this experiment, we predicted that alder would have the highest $\mathrm{N}$ cycling rates, followed by birch, and beech. We predicted there would be a corresponding shift in soil microbial functional gene abundances, and fungal ITS and bacterial 16S rDNA gene abundance. We hypothesized that: 1) due to decreased soil $\mathrm{pH}$ under beech forest the abundance of the bacterial $16 \mathrm{~S}$ 
rDNA gene marker will decrease, 2) alder will increase soil $\mathrm{N}$ while increasing rates of nitrification and corresponding gene abundance; and 3) birch will increase the abundance of soil bacterial communities (16S genes) compared with beech.

\section{Materials and methods}

\subsection{Study design}

Soil samples $(0-10 \mathrm{~cm}$ top horizon, without litter layer) were taken from the BangorDIVERSE forest diversity experiment located in Abergwyngregyn, North Wales $\left(53^{\circ} 14^{\prime} 15^{\prime \prime} \mathrm{N}, 4^{\circ} 1^{\prime} 4^{\prime \prime} \mathrm{W}\right)$. The site was established in March 2004 and consists of replicated $(n=4)$ plots of one, two and three tree species mixtures at a density of 10,000 stems ha ${ }^{-1}$ (Ahmed et al., 2016; Gunina et al., 2017; Scullion et al., 2014). The site has a mean annual temperature of $11^{\circ} \mathrm{C}$ and mean annual precipitation of 960 mm. Within BangorDIVERSE in 2016, seven treatments were sampled: monocultures of alder (Alnus glutinosa), birch (Betula pendula), and beech (Fagus sylvatica), and two and three species mixtures of alder + birch, beech + birch, alder + beech, alder + birch + beech. These species were chosen based on their contrasting soil and litter properties, mycorrhizal status and N-fixing ability. Soils were sieved to pass $2 \mathrm{~mm}$ and divided to three parts: one was stored frozen under $-80^{\circ} \mathrm{C}$ and used later for DNA isolation, second one was immediately used for the estimation of $\mathrm{N}$ process rates, and third one was dried under $105^{\circ} \mathrm{C}$ and used for $\mathrm{pH}$ and soil organic carbon (SOC) and $\mathrm{N}$ measurement. $\mathrm{pH}$ was measured in water, with the soil to water ratio is $1: 2.5$. Soil $\mathrm{C}$ and $\mathrm{N}$ were measured by dry combustion (Analytic Jena) (Supplimentary Table 6-1).

\subsection{DNA isolation and $q P C R$}

DNA isolation, and targeted gene abundances were quantified following the protocol described in Ribbons et al. (2016). Briefly, microbial DNA was extracted from $0.10 \mathrm{~g}$ of soil, using a Power Clean ${ }^{\circledR}$ soil extraction kit (Mo-Bio Laboratories Inc., Carlsbad, CA). DNA extracts were quantified using a nanodrop spectrophotometer, and 1:10 (v/v) dilutions of DNA extracts were used for downstream analyses.

\subsection{Nitrogen process rates}

Soil net and gross nitrification rates were determined according Mulvaney (1996). Briefly, $200 \mu 1$ of $50 \mathrm{mM}$ solution of $\mathrm{NH}_{4} \mathrm{Cl}$ was added to field-moist soil (equal to $2 \mathrm{~g}$ of dry mass) and the samples incubated for $7 \mathrm{~d}$ at $25^{\circ} \mathrm{C}$. Subsequently, the soils were extracted with $10 \mathrm{ml}$ of $1 \mathrm{M} \mathrm{KCl}(200 \mathrm{rev}$ 
$\min ^{-1}, 1 \mathrm{~h}$ ), centrifuged (10 $\mathrm{min}, 2700 \mathrm{~g}$ ), and $\mathrm{NH}_{4}{ }^{+}$and $\mathrm{NO}_{3}{ }^{-}$concentrations in the extracts were determined colorimetrically according to the methods of Mulvaney (1996) and Miranda et al. (2001), respectively. Net nitrification rate was calculated from the increase in $\mathrm{NO}_{3}{ }^{-}$concentration, whereas gross nitrification was estimated by calculating the decrease in $\mathrm{NH}_{4}{ }^{+}$concentration during the experiment. Soil ammonification rate was determined using the anaerobic incubation method (Mulvaney, 1996). Briefly, field-moist soil (equal to $2 \mathrm{~g}$ of dry mass) was incubated with $10 \mathrm{ml}$ of distilled water in the absence of $\mathrm{O}_{2}$ at $40^{\circ} \mathrm{C}$ for $7 \mathrm{~d}$. Subsequently, dry $\mathrm{KCl}$ was added to the tubes to achieve a concentration of $1 \mathrm{M}$. The soils were then extracted and the amount of $\mathrm{NH}_{4}{ }^{+}$ accumulated determined as described above.

\subsection{Statistical analysis}

Analysis of variance (ANOVA) was used to determine differences between the seven treatments for the soil gene abundances and the $\mathrm{N}$ process rates (alpha $=0.05)$. Aside from the gene copy data, no transformations were required, and since no significant main effects were observed, no post-hoc tests were completed. Principal components analyses (PCA) were conducted in R version 3.3.2 (vegan and ggplot2 packages) and were used to explore forest type effects on soil microbial communities, in addition to $\mathrm{N}$ process rates, and soil physical properties.

\section{Results}

\subsection{Soil properties}

Significant differences in soil $\mathrm{pH}$ and total $\mathrm{C}$ and $\mathrm{N}$ were seen between the different treatments (Supplementary Table 6-1). Specifically, the maximal C and N contents were found for the Birch + Beech forests compare to pure beech stands. For $\mathrm{pH}$ values the lowest values were found under Alder + Birch forest, whereas they were higher in all other stands.

\subsection{Microbial and $N$ cycling gene abundance}

Total fungal and bacterial biomass as well as $\mathrm{N}$ cycling gene abundance (including markers for denitrifying bacteria (nirK and nirS), and ammonia-oxidizing archaea and bacteria) were not significantly affected by different tree species (Fig. 6-1). 

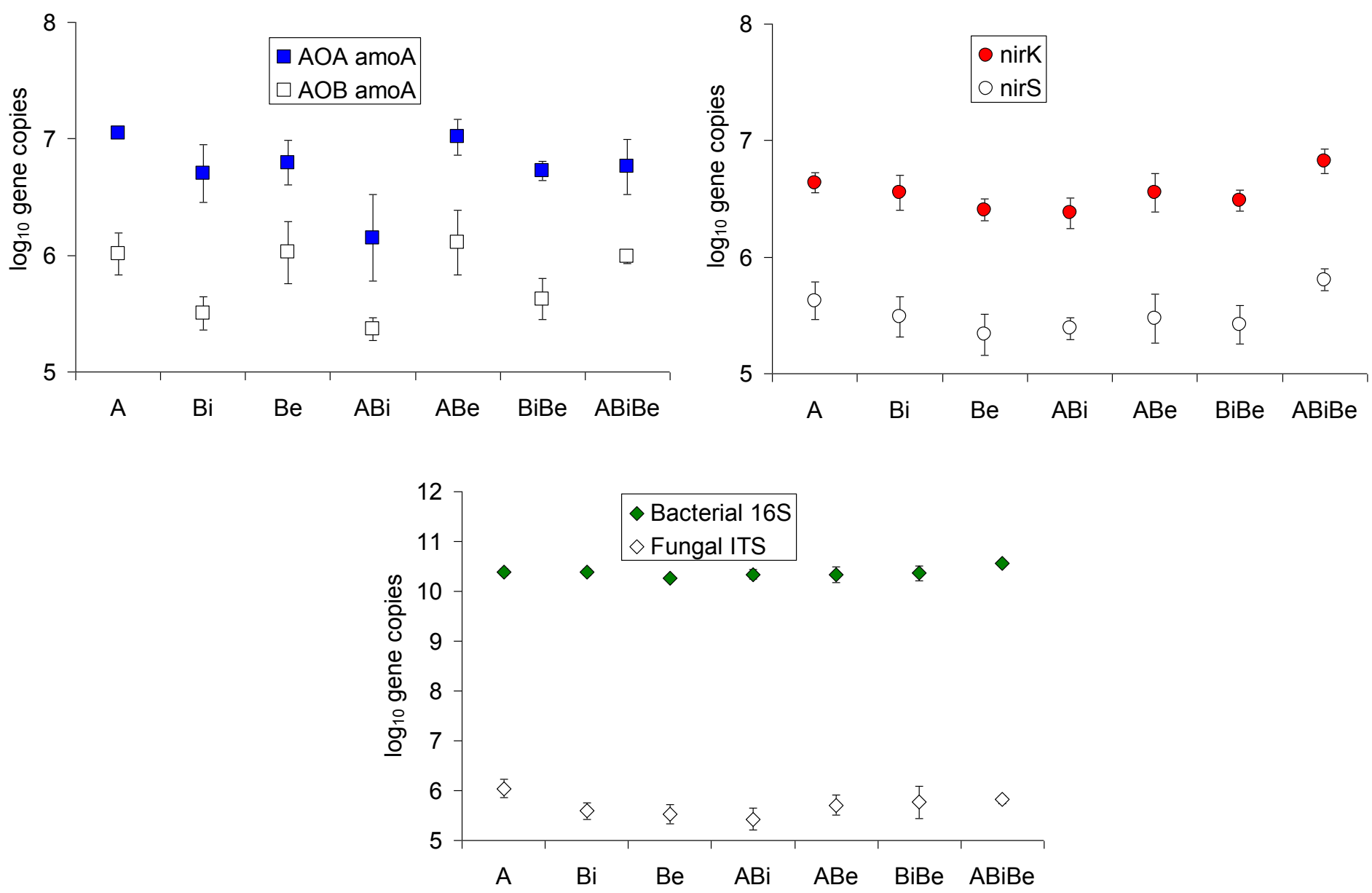

Figure 6-1. Total abundance of ammonia-oxidizing archaea and bacteria amoA AOA and AOB, denitrifying bacteria nirS and nirK and fungal ITS, bacterial 16S, presented as $\log _{10}$ gene copies compared across the 7 forest treatments. Values represent means $\pm S E(n=4)$. Al - alder, Bi birch, Be - beech, AlBi - alder+birch, AlBe - alder+beech, AlBiBe - alder+birch+beech.

\section{3. $N$ process rate measurements}

Overall, soils from the alder-only treatment exhibited the highest rates of net nitrification, particularly in comparison to soil collected from under the mixtures of alder + birch, and alder + beech and three species mixed forest. In contrast, there were no differences in net nitrification rates between other stands. Birch had higher rates of ammonification in comparison to the beech, and birch + beech treatments. There were no other differences in net ammonification rates between the other tree species mixtures. Soil from the alder monoculture had higher gross potential nitrification in comparison to alder + beech, but there were no other differences between tree species mixtures (Fig. 6-2). 

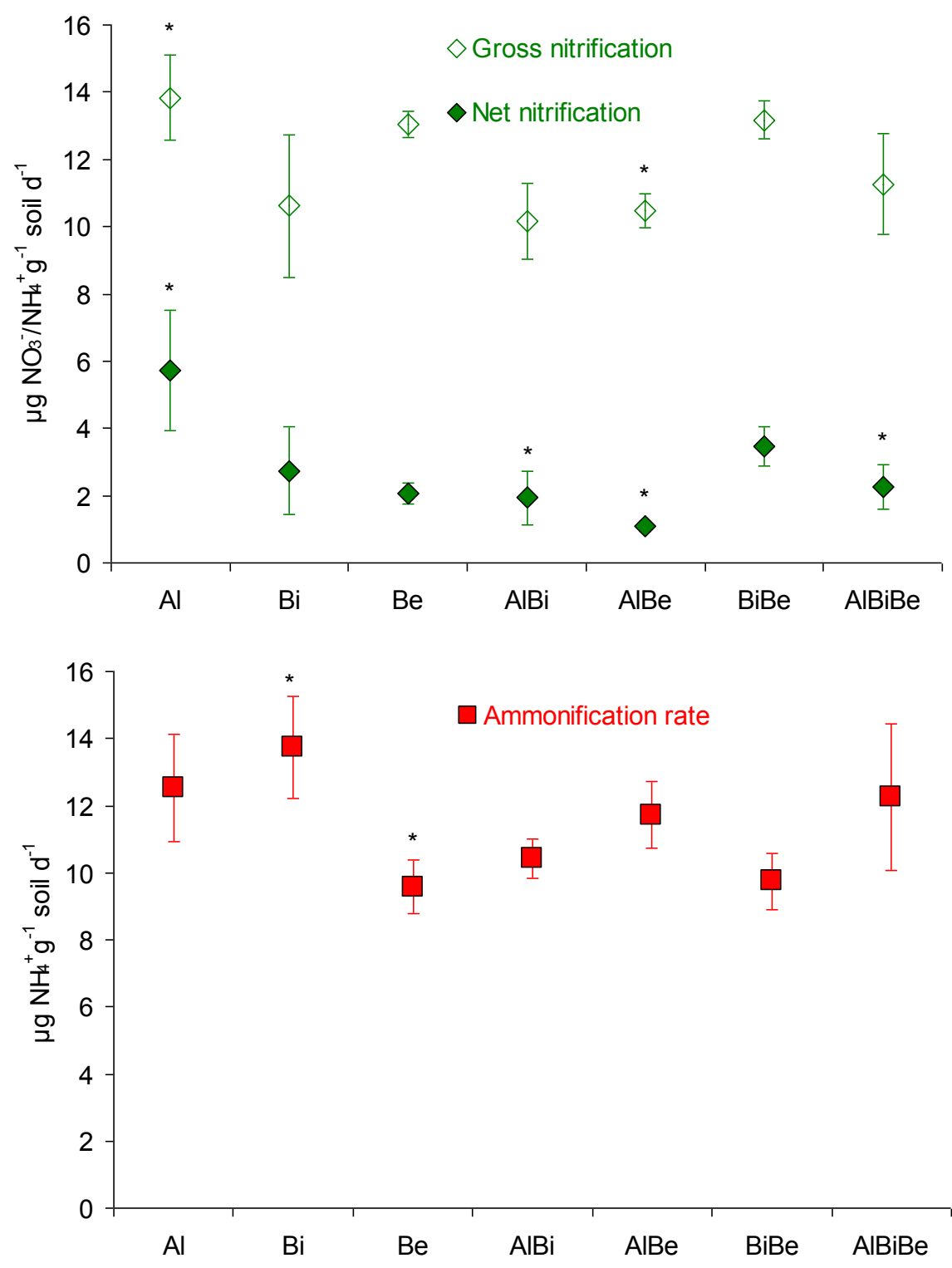

Figure 6-2. Nitrogen cycling process rates among the seven forest treatments. Nitrification rates are from an aerobic incubation with $\mathrm{NH}_{4} \mathrm{SO}_{4}$, whereas ammonification rates are from an anaerobic incubation. Values represent means $\pm S E(n=4)$. Al - alder, Bi - birch, Be - beech, AlBi alder+birch, AlBe - alder+beech, AlBiBe - alder+birch+beech. Stars reflect significant differences $(p<0.05)$ between alder and other forests (in case of gross and net nitrification rates) and between birch and beech in case of ammonification rates. 


\subsection{Relationships between gene abundance and soil properties}

Three variations of principal components analyses were performed. The first contained all genes, soil chemistry, and $\mathrm{N}$ process rates data; the second contained genes and soil chemistry data; and the third contained only genes data (Fig. 6-3a-c). For the first model- Principal component 1 explained $33.1 \%$ of the variation and was mainly associated with fungal ITS and ammoniaoxidizing archaea (AOA amoA) (Fig. 6-3a). Principal component 2 explained 17.2\% of the variation and was mainly associated with $\mathrm{NH}_{4}{ }^{+}$concentrations and nitrification rates (Fig. 6-3a). For the second model, Principal component 1 explained $40.2 \%$ of the variation and was mainly associated with ammonia-oxidizing archaea (AOA $a m o A$ ) (Fig. 6-3b). Principal component 2 explained $21.4 \%$ of the variation and was mainly associated with $\mathrm{NH}_{4}{ }^{+}$concentrations and $\mathrm{pH}$ (Fig. 6-3b). For the third model, Principal component 1 explained 57.2\% of the variation and was mainly associated with ammonia-oxidizing archaea and bacteria (AOB and AOA amoA) (Fig. 6-3c). Principal component 2 explained $17.3 \%$ of the variation and was mainly associated with niK (Fig. 6-3c). 


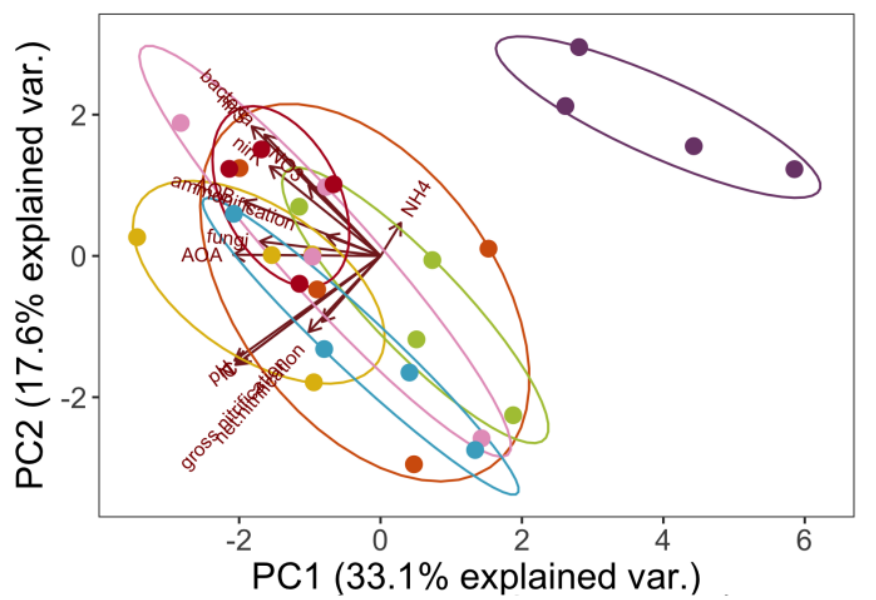

groups

$-1 . \mathrm{Al}$

- $2 . \mathrm{Bi}$

- $3 . \mathrm{Be}$

- $4 . \mathrm{AlBi}$

- $5 . \mathrm{AlBe}$

- 6. $\mathrm{BiBe}$

- 7.AlBiBe

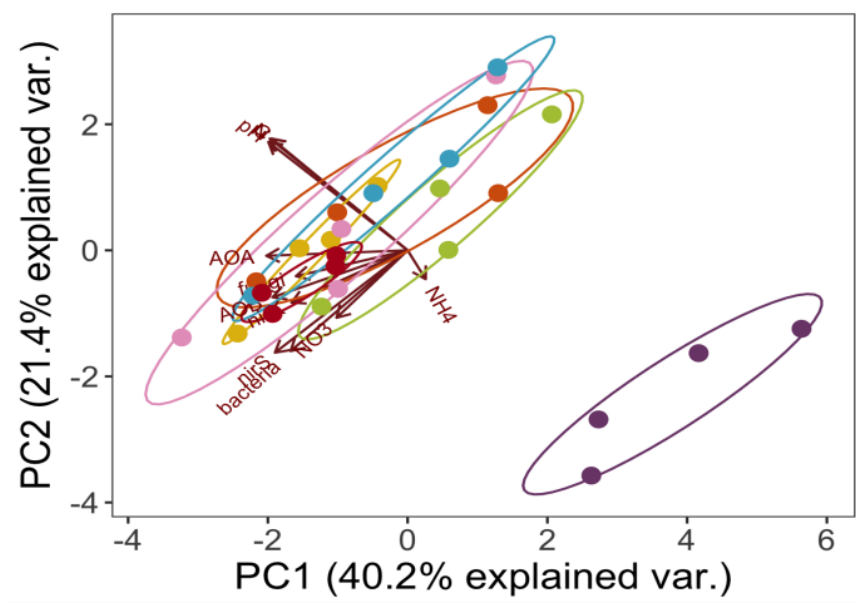

groups

- 1.Al

- 2.Bi

- 3.Be

- 4.AIBi

- 5.AIBe

- 6.BiBe

- 7.AlBiBe

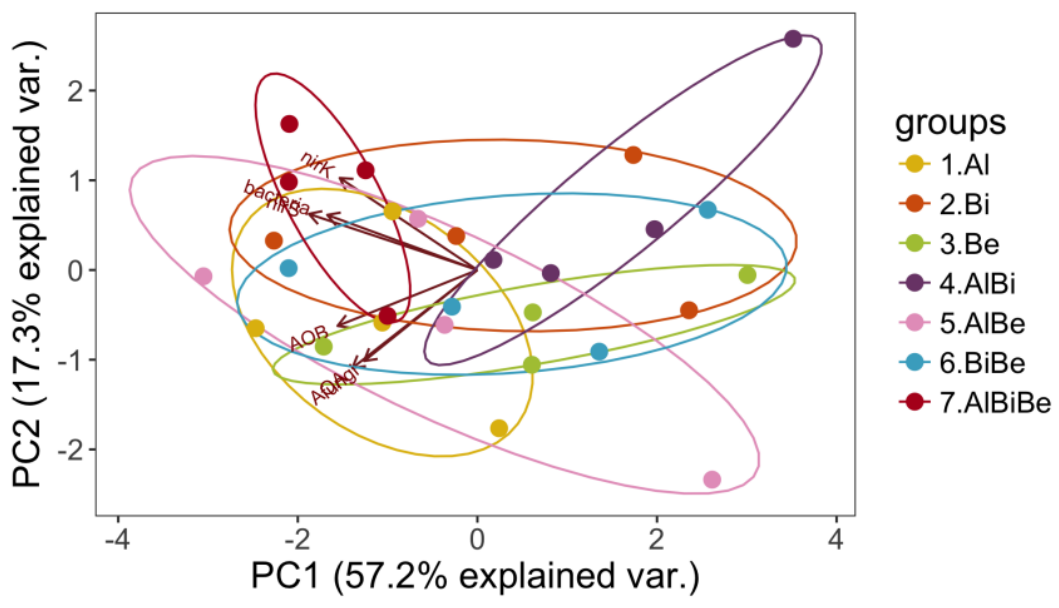

Figure 6-3. Principal Components Analysis of all gene copies, $N$ process rates, and soil chemistry data as dependent variables, grouped among the 7 forest treatments as the explanatory variables (a), with gene copies and soil chemistry data only (b), and with only gene copies grouped by the 7 forest treatments (c). Al-alder, Bi - birch, Be - beech, AlBi - alder+birch, AlBe - alder+beech, AlBiBe - alder+birch+beech. 


\section{Discussion}

Our results show that tree diversity in young forest stands, and associated differences in the quality and quantity of litter had no major impact on microbial community composition, functional gene abundance, but did affect ecosystem nutrient processing rates. The first and third hypotheses were not supported by experimental data: there was no documented tree species or mixtures effects on soil microbial community abundances (H1) as assessed by fungal ITS and bacterial $16 S$. The second hypothesis was supported as the different functional species traits altered $\mathrm{N}$ process rates, although this was not evidenced in the functional genes (denitrifying bacteria nirK and nirS and ammoniaoxidising bacteria and archaea $\mathrm{AOB}$ and $\mathrm{AOA}$ amoA) tied to nitrogen cycling. We did observe a tree species, but not a mixture effect on $\mathrm{N}$ process rates, specifically with soils under $\mathrm{N}$-fixing alder having higher rates of net and gross nitrification.

These results contrast to some extent with a previous on soil microbial communities within the same experiment (Gunina et al., 2017), which found some small differences in microbial community composition in the upper $10 \mathrm{~cm}$ of soil based on phospholipid fatty acid (PLFA) analysis. Gunina et al. (2017) found that the addition of beech into any species mixtures resulted in different content of microbial biomarkers compared to other tree species, generally with a decrease in bacterial biomarkers. In agreement with the present study, however, they found that N-fixing alder did not alter the relative abundance of different fungal or bacterial PLFA biomarkers. Our results may be partially explained as a lag in response time, where soil microbial communities are responding to different litter and nutrient inputs, and take time to stabilize. For example, soil $\mathrm{C}$ and $\mathrm{N}$ stocks initially increase as forests establish (Novara et al., 2014), reach peak accumulation rates which decline as forests reach maturity (DeLuca and Boisvenue, 2012). Similarly, C and N rates stabilize 30-50 years after afforestation (Fu et al., 2015; Gunina et al., 2017), which suggests forest ecosystems may take several decades to reach a dynamic equilibrium and is consistent with the lack of tree species effects observed in this study. Alternatively, differences in PLFA marker abundance within individual fungal species may make the PLFA approach more sensitive to shifts in fungal community composition, rather than providing an accurate reporting of fungal biomass.

The lack of difference in functional gene abundance could be explained by a number of different mechanisms. Firstly, it is known that the majority of the microbial biomass in soil is inactive and not subject to rapid rates of turnover (Rousk and Baath, 2007). In contrast, the active proportion of the biomass may be far more responsive to changes in soil conditions, however, these would be obscured by a lack of change in the inactive population. To circumnavigate this, further 
work should therefore focus on the determining the gene transcript levels in soil rather than relying on gene abundance alone (Theodorakopoulos et al., 2017; Wertz et al., 2016). In addition, it is also possible that measurements of gene abundance are also detecting DNA in dead microbial cells (Carini et al., 2016), although the significance of this still remains uncertain.

\section{Conclusions}

In summary, this investigation of the impact of afforestation with mono, two and three species mixtures of alder, birch or beech on $\mathrm{N}$ cycling processes did not reveal any differences in $\mathrm{N}$ functional gene abundance. In contrast, differences in $\mathrm{N}$ cycling rates were found for the pure alder forests ( $\mathrm{N}$-fixing plant), namely high gross and net nitrification rates compared with the mixtures with birch or beech. In addition, lower ammonification rates were found in the pure beech forest, compared to pure birch. Thus, we recommend that $\mathrm{N}$ functional gene abundance, transcript level and $\mathrm{N}$ processes rates should all be taken into account when estimating the effect of afforestation with pure and mix tree species on $\mathrm{N}$ cycling in soils. 
Acknowledgements This study was supported by a scholarship grant from the Erasmus Mundus Joint Doctoral Programme "Forest and Nature for Society" (FONASO) awarded to A. Gunina and R. Ribbons. The authors acknowledge the financial support provided by the Welsh Government and Higher Education Funding Council for Wales through the Sêr Cymru National Research Network for Low Carbon, Energy and Environment.

\section{References}

Ahmed, I.U., Smith, A.R., Jones, D.L., Godbold, D.L., 2016. Tree species identity influences the vertical distribution of labile and recalcitrant carbon in a temperate deciduous forest soil. For. Ecol. Manag. 359, 352-360. doi:10.1016/j.foreco.2015.07.018

Aponte, C., García, L.V., Marañón, T., 2013. Tree species effects on nutrient cycling and soil biota: A feedback mechanism favouring species coexistence. For. Ecol. Manag., Influence of tree species on forest soils: New evidence from field studies 309, 36-46. doi:10.1016/j.foreco.2013.05.035

Carini, P., Marsden, P.J., Leff, J.W., Morgan, E.E., Strickland, M.S., Fierer, N., 2016. Relic DNA is abundant in soil and obscures estimates of soil microbial diversity. Nat. Microbiol. 2, nmicrobiol2016242. doi:10.1038/nmicrobiol.2016.242

DeLuca, T.H., Boisvenue, C., 2012. Boreal forest soil carbon: distribution,function and modelling. Forestry doi:10.1093/forestry/cps003.

Fu, X., Yang, F., Wang, J., Di, Y., Dai, X., Zhang, X., H, W., 2015. Understory vegetation leads to changes in soil acidity and in microbial communities 27 years after reforestation. Sci. Total Environ. 502, 280-286.

Godbold, D.L., Hoosbeek, M.R., Lukac, M., Cotrufo, M.F., Janssens, I.A., Ceulemans, R., Polle, A., Velthorst, E.J., Scarascia-Mugnozza, G., Angelis, P.D., Miglietta, F., Peressotti, A., 2006. Mycorrhizal Hyphal Turnover as a Dominant Process for Carbon Input into Soil Organic Matter. Plant Soil 281, 15-24. doi:10.1007/s11104-005-3701-6

Gunina, A., Smith, A.R., Godbold, D.L., Jones, D.L., Kuzyakov, Y., 2017. Response of soil microbial community to afforestation with pure and mixed species. Plant Soil 412, 357-368. doi:10.1007/s11104-016-3073-0

Haase, J., Castagneyrol, B., Cornelissen, J.H.C., Ghazoul, J., Kattge, J., Koricheva, J., SchererLorenzen, M., Morath, S., Jactel, H., 2015. Contrasting effects of tree diversity on young tree growth and resistance to insect herbivores across three biodiversity experiments. Oikos 124, 1674-1685. doi:10.1111/oik.02090

Hackl, E., Pfeffer, M., Donat, C., Bachmann, G., Zechmeister-Boltenstern, S., 2005. Composition of the microbial communities in the mineral soil under different types of natural forest. Soil Biol. Biochem. 37, 661-671.

Hobbie, S.E., 1992. Effects of plant species on nutrient cycling. Trends Ecol. Evol. 7, 336-339. doi:10.1016/0169-5347(92)90126-V

Holling, C.S., 1973. Resilience and Stability of Ecological Systems. Annu. Rev. Ecol. Syst. 4, 1-23. doi:10.1146/annurev.es.04.110173.000245

Jewell, M.D., Shipley, B., Low-Décarie, E., Tobner, C.M., Paquette, A., Messier, C., Reich, P.B., 2017. Partitioning the effect of composition and diversity of tree communities on leaf litter decomposition and soil respiration. Oikos 126, 959-971. doi:10.1111/oik.03868 
Levy-Booth, D.J., Prescott, C.E., Grayston, S.J., 2014. Microbial functional genes involved in nitrogen fixation, nitrification and denitrification in forest ecosystems. Soil Biol. Biochem. 75, 11-25. doi:10.1016/j.soilbio.2014.03.021

Loreau, M., de Mazancourt, C., 2013. Biodiversity and ecosystem stability: a synthesis of underlying mechanisms. Ecol. Lett. 16, 106-115. doi:10.1111/ele.12073

Mellec, A. le, Habermann, M., Michalzik, B., 2009. Canopy herbivory altering C to N ratios and soil input patterns of different organic matter fractions in a Scots pine forest. Plant Soil 325, 255-262. doi:10.1007/s11104-009-9976-2

Miranda, K.M., Espey, M.G., Wink, D.A., 2001. A rapid, simple spectrophotometric method for simultaneous detection of nitrate and nitrite. Nitric Oxide Biol. Chem. 5, 62-71. doi:10.1006/niox.2000.0319

Mulvaney, R.L., 1996. Methods of Soil Analysis. Part 3 - Chemical Methods. Soil Science Society of America, Inc., Wisconsin, USA.

Novara, A., La Mantia, T., Rühl, J., Badalucco, L., Kuzyakov, Y., Gristina, L., Laudicina, V.A., 2014. Dynamics of soil organic carbon pools after agricultural abandonment. Geoderma 235, 191-198. doi:10.1016/j.geoderma.2014.07.015

Purahong, W., Durka, W., Fischer, M., Dommert, S., Schöps, R., Buscot, F., Wubet, T., 2016. Tree species, tree genotypes and tree genotypic diversity levels affect microbe-mediated soil ecosystem functions in a subtropical forest. Sci. Rep. 6. doi:10.1038/srep36672

Ribbons, R.R., Levy-Booth, D.J., Masse, J., Grayston, S.J., McDonald, M.A., Vesterdal, L., Prescott, C.E., 2016. Linking microbial communities, functional genes and nitrogen-cycling processes in forest floors under four tree species. Soil Biol. Biochem. 103, 181-191. doi:10.1016/j.soilbio.2016.07.024

Rousk, J., Baath, E., 2007. Fungal biomass production and turnover in soil estimated using the acetate-in-ergosterol technique. Soil Biol. Biochem. 39, 2173-2177. doi:10.1016/j.soilbio.2007.03.023

Scullion, J., Smith, A.R., Gwynn-Jones, D., Jones, D.L., Godbold, D.L., 2014. Deciduous woodland exposed to elevated atmospheric $\mathrm{CO} 2$ has species-specific impacts on anecic earthworms. Appl. Soil Ecol. 80, 84-92. doi:10.1016/j.apsoil.2014.03.016

Theodorakopoulos, N., Lognoul, M., Degrune, F., Broux, F., Regaert, D., Muys, C., Heinesch, B., Bodson, B., Aubinet, M., Vandenbol, M., 2017. Increased expression of bacterial amoA during an N2O emission peak in an agricultural field. Agric. Ecosyst. Environ. 236, 212 220. doi:10.1016/j.agee.2016.12.002

Verheyen, K., Vanhellemont, M., Auge, H., Baeten, L., Baraloto, C., Barsoum, N., BilodeauGauthier, S., Bruelheide, H., Castagneyrol, B., Godbold, D., Haase, J., Hector, A., Jactel, H., Koricheva, J., Loreau, M., Mereu, S., Messier, C., Muys, B., Nolet, P., Paquette, A., Parker, J., Perring, M., Ponette, Q., Potvin, C., Reich, P., Smith, A., Weih, M., Scherer-Lorenzen, M., 2016. Contributions of a global network of tree diversity experiments to sustainable forest plantations. Ambio 45, 29-41. doi:10.1007/s13280-015-0685-1

Wertz, S., Goyer, C., Zebarth, B.J., Tatti, E., Burton, D.L., Chantigny, M.H., Filion, M., 2016. The amplitude of soil freeze-thaw cycles influences temporal dynamics of $\mathrm{N} 2 \mathrm{O}$ emissions and denitrifier transcriptional activity and community composition. Biol. Fertil. Soils 52, 11491162. doi:10.1007/s00374-016-1146-0 


\section{Chapter 7 Article V Sugars in soil and sweets for microorganisms: Review of origin, content, composition and fate}

Anna Gunina ${ }^{1,2}$ and Yakov Kuzyakov ${ }^{1,3}$

${ }^{1}$ Department of Agricultural Soil Science, Georg-August-University of Göttingen, Germany

${ }^{2}$ Department of Soil Biology and Biochemistry, Dokuchaev Soil Science Institute, Russian Federation

${ }^{3}$ Department of Soil Science of Temperate Ecosystems, Georg-August-University of Göttingen, Germany

Soil Biology and Biochemistry, 2015, 90, 87-100.

Author contributions: Anna Gunina and Yakov Kuzyakov contributed equally to this work.

Keywords: carbohydrates in soil, glucose, microbial utilization, biochemical transformation, low molecular weight organics. 


\section{Abstract}

Sugars are the most abundant organic compounds in the biosphere because they are monomers of all polysaccharides. We summarize the results of the last 40 years on the sources, content, composition and fate of sugars in soil and discuss their main functions. We especially focus on sugar uptake, utilization and recycling by microorganisms as this is by far the dominating process of sugar transformation in soil compared to sorption, leaching or plant uptake. Moreover, sugars are the most important carbon $(\mathrm{C})$ and energy source for soil microorganisms.

Two databases have been created. The $1^{\text {st }}$ database focused on the contents of cellulose, noncellulose, hot-water and cold-water extractable sugars in soils (348 data, 32 studies). This enabled determining the primary (plant-derived) and secondary (microbially and soil organic matter (SOM) derived) sources of carbohydrates in soil based on the galactose+mannose/arabinose+xylose $(\mathrm{GM} / \mathrm{AX})$ ratio. The $2^{\text {nd }}$ database focused on the fate of sugar $\mathrm{C}$ in soil (734 data pairs, 32 studies using ${ }^{13} \mathrm{C}$ or ${ }^{14} \mathrm{C}$ labeled sugars). ${ }^{13} \mathrm{C}$ and ${ }^{14} \mathrm{C}$ dynamics enabled calculating the: 1) initial rate of sugar mineralization, 2) mean residence time (MRT) of $\mathrm{C}$ of the applied sugars, and 3) MRT of sugar $\mathrm{C}$ incorporated into 3a) microbial biomass and 3b) SOM.

The content of hexoses was 3-4 times higher than pentoses, because hexoses originate from plants and microorganisms. The GM/AX ratio of non-cellulose sugars revealed a lower contribution of hexoses in cropland and grassland soils (ratio 0.7-1) compared to forest (ratio 1.5).

${ }^{13} \mathrm{C}$ and ${ }^{14} \mathrm{C}$ studies showed very high initial rate of glucose mineralization $\left(1.1 \% \mathrm{~min}^{-1}\right)$ and much higher rate of sugars uptake by microorganisms from soil solution. Considering this rate along with the glucose input from plants and its content in soil solution, we estimate that only about $20 \%$ of all sugars in soil originate from the primary source - decomposition of plant litter and rhizodeposits. The remaining $80 \%$ originates from the secondary source - microorganisms and their residues. The estimated MRT of sugar $\mathrm{C}$ in microbial biomass was about 230 days, showing intense and efficient internal recycling within microorganisms. The assessed MRT of sugar C in SOM was about 360 days, reflecting the considerable accumulation of sugar $\mathrm{C}$ in dead microbial biomass and its comparatively slow external recycling.

The very rapid uptake of sugars by microorganisms and intensive recycling clearly demonstrate the importance of sugars for microbes in soil. We speculate that the most important functions of sugars in soil are to maintain and stimulate microbial activities in the rhizosphere and detritusphere leading to mobilization of nutrients by accelerated SOM decomposition - priming effects. We conclude that the actual contribution of sugar C (not only whole sugar molecules, which 
are usually determined) to SOM is much higher than the $10 \pm 5 \%$ commonly measured based on their content.

\section{Introduction - Why sugars?}

Sugars are the most abundant organic compounds in the biosphere because they are the basic components of all polysaccharides: cellulose, hemicellulose (polyoses), starch, pectin, fructanes, and glucanes as well as of chitin (consists from amino sugars) (Kogel-Knabner, 2002). Considering the dominance of polysaccharides in plants (50-70\% of dry mass), they are the most important primarily input of organic carbon (C) in soil. With a mean residence time (MRT) of few weeks to months (Martin et al., 1974), polysaccharides are decomposed by exoenzymes (cellulases, xylanases, glucosidases, hydrolases, chitinases) to oligo- and monosaccharides (termed sugars). Cellulose is the most abundant biopolymer and, consequently, glucose is the most abundant monomer released by its decomposition in soil. Sugars therefore dominate within low molecular weight organic substances (LMWOS) in all soils and affect various processes not only as a chemical compound group per se, but especially as $\mathrm{C}$ and an energy source for microorganisms.

All oligo- and monosaccharides are soluble, easily available for microorganisms, and are captured rapidly by microbes and used for maintenance (both respiration and anabolism), growth and $\mathrm{C}$ storage. Because sugars dominate LMWOS and cell metabolism, their role for microbial life in soil cannot be overestimated. For example, the sugar concentration in soil solution stimulates the transition of microorganisms from dormant or potentially active to the active stages (Blagodatskaya and Kuzyakov, 2013). This activation contributes further to exoenzyme production, thus accelerating the decomposition of soil organic matter (SOM) and the release of stored nutrients, mainly N, P and S. This makes sugars the most common and no doubt very efficient substance group to induce priming effects (Kuzyakov, 2010).

Another important and frequently neglected relevance of carbohydrates is their contribution to aggregates formation - and thus to the formation of soils from parent materials. Poly-, oligo- and monosaccharides become sticky with increasing the concentrations and drying, and bind mineral and organic particles, resulting in microaggregates formation (Oades, 1984; Six et al., 1999). Even the role of particulate organic matter (POM) for aggregate formation is mainly connected with the release of polysaccharides and sugars due to POM decomposition.

Within the three most abundant classes of LMWOS in soil - sugars, carboxylic acids and amino acids - the concentration of sugars is about 2-3 times higher than that of both other classes. 
The fate and significance of other LMWOS in soil were intensively reviewed earlier: carboxylic acids (Jones, 1998) and amino acids (Jones et al., 2005), and we refer the readers to these excellent reviews for further information. No overview, however, focused on the composition, fate and relevance of sugars in soil. The sole detailed review about carbohydrates in soils was published about 40 years ago (Cheshire, 1979) and focused on the concentration and composition of sugars, but not on their fate and not on their relevance in soil. In the meantime, numerous studies have analyzed not only the composition of sugars, but also their fate in the soil. This includes the main processes in which they are involved, their residence time, microbial utilization, biochemical pathways, and contribution to SOM formation and C sequestration. Other work has described environmental factors and soil parameters, land use, etc. Therefore, our main objective is to provide a comprehensive overview about the fate of sugars in soil, including:

- analyzing the primary and secondary sources of carbohydrates in soil;

- re-evaluating the content and composition of cellulose and non-cellulose sugars in soil, including analysis of their dependence on soil parameters and origin;

- assessing the main fate of sugars in soil, including their sorption, migration through the soil profile, plant uptake and microbial uptake and utilization;

- estimating the rates of main microbial utilization processes;

- estimating annual sugar production and its microbial recycling in soil based on the cellulose and non-cellulose sugar content and their decomposition rates;

- evaluating the role of sugars for aggregate formation, SOM accumulation and priming effects; and

- providing an overall scheme of sugar transformation and recycling in soil.

It is beyond the scope of this review to provide methodological details of carbohydrate extraction, purification and analysis (Amelung et al., 1996; Cheshire, 1979).

\section{Materials and methods}

We use the term carbohydrates when we refer to monosaccharides, disaccharides, oligosaccharides and polysaccharides without their differentiation. In some literature, 'saccharides' are used as a synonym of carbohydrates. For specification we use the respective terms (i.e. polysaccharides, monosaccharides, etc.). The term 'sugars' is used for mono- and disaccharides. 
For the review preparation, two sets of literature data were collected: 1) content and concentration of various groups of sugars in soils and soil solutions and 2) mineralization rates of sugars in soil and their participation in various fluxes including incorporation into microbial biomass (MB) and SOM.

\subsection{Sugar content and composition}

The first database is focused on sugar contents in soils and soil solutions and contains 348 data from 32 studies. Articles were searched in the Web of Knowledge and Scopus using the key words: "soil*" AND "carbohydrate*”, "sugar content" AND "soil*”. Information was collected on total sugars as well as content of individual sugars extracted by various procedures. Based on the extractants and pre-treatments (e.g. various hydrolysis procedures, temperature and soil:solution ratios), all sugars were divided into the following groups: 1) total, 2) non-cellulose, 3) hot-water extractable and 4) cold-water extractable. The specific soil parameters ( $\mathrm{C}$ and $\mathrm{N}$ contents, $\mathrm{pH}$, texture), land use, experiment conditions, depth of soil sampling and climate were included in the database. Only articles with total $\mathrm{C}$ in soil $<6 \%$ of DW were included in order to consider mineral soils only. Soil texture was classified according to clay content as: clayey ( $>25 \%$ clay), loamy (15$25 \%$ clay) and sandy (10-15\% clay). We found no carbohydrate studies on soils with $<10 \%$ clay. All plant species or vegetation types were classified into three functional groups: forest, agricultural crops and grasslands. The original data on sugar contents $\left(\mathrm{mg} \mathrm{kg}^{-1}, \mathrm{mg} \mathrm{g}^{-1}, \mathrm{mg} 100 \mathrm{~g}^{-1}, \mathrm{\mu g} \mathrm{g}^{-1}, \mathrm{~g} \mathrm{~kg}^{-1}\right.$ soil) were standardized to sugar $\mathrm{C}$ per $\mathrm{g} \mathrm{C} \mathrm{kg}^{-1}$ soil.

This database was used to analyze the primary (plant-derived) and secondary (microbially and SOM-derived) sources of sugars in soil and to evaluate the role of carbohydrates in aggregate formation, SOM dynamics and priming effects. The hexose/pentose ratio (galactose+mannose/arabinose+xylose) (GM/AX) for the non-cellulose sugars was calculated to analyze the origin of sugars in the soil (Oades, 1984). To estimate the possible contribution of plant sources to the origin of soil sugars, this ratio was also calculated for the plant tissues of the three plant functional groups: forest, agricultural crops and grasslands. The GM/AX ratio for microbial residues was taken $>2.0$ (Oades, 1984).

Our analysis was mainly focused on the total and non-cellulose sugars. We paid less attention to the sugar composition extracted by $\mathrm{NaOH}$ because alkali extracts also fulvic and humic acids, which were not in the scope of this review. 


\subsection{Fate of sugars}

The second $\left(2^{\text {nd }}\right)$ database was developed to evaluate the fate of carbohydrate-C in soil. All polysaccharides pass through the sugar pool during their decomposition in soil. We therefore mainly focused on the fate of sugar $\mathrm{C}$. Because this fate in soil cannot be investigated without isotopic labeling and tracing, only those papers using ${ }^{13} \mathrm{C}$ or ${ }^{14} \mathrm{C}$ labeled sugars were included. Articles were searched in Web of Knowledge and Scopus using the following key words: "sugar* decomposition in soil*", "glucose decomposition in soil*", "glucose ${ }^{13} \mathrm{C}$ soil*", "glucose ${ }^{14} \mathrm{C}$ soil*". This database contains 734 data pairs from $32{ }^{13} \mathrm{C}$ - and ${ }^{14} \mathrm{C}$-labeling studies. The sugar $\mathrm{C}$ fate was analyzed based on ${ }^{13} \mathrm{C}$ or ${ }^{14} \mathrm{C}$ partitioning between the following pools: 1) mineralized to $\mathrm{CO}_{2}, 2$ ) incorporated into soil MB and 3) incorporated into SOM.

All data about the fate were analyzed and presented in dynamics, i.e. depending on the time after sugar input into the soil. This enabled calculating: 1) maximal rate of glucose C decomposition, 2) MRT of $\mathrm{C}$ of the initially applied sugars, 3) MRT of C in 3a) MB and 3b) SOM pools.

Most studies on sugar fate in soil have been conducted using glucose due to its high abundance: glucose originates from cellulose decomposition and is also present in root exudates (Derrien et al., 2004). Even though the presented data on the fate of sugars in soil were mainly obtained based on glucose, the fate of other sugars is very similar (Derrien et al., 2007; Gunina et al., 2014).

All results from both databases are presented as means \pm standard errors (SE).

\subsection{Calculations and statistical analyses}

Sugar $\mathrm{C}$ mineralization to $\mathrm{CO}_{2}$ was estimated using the literature overview on glucose ${ }^{14} \mathrm{C}$ or ${ }^{13} \mathrm{C}$ decomposition within the first $24 \mathrm{~h}$ after its addition to soil based on 74 data collected from 16 studies. The maximal rate of glucose $\mathrm{C}$ decomposition was calculated as a tangent to its initial mineralization rate, using single exponential kinetics (Eq. 1) (Kuzyakov, 2011; Parton et al., 1987). The MRT of the glucose $\mathrm{C}$ was calculated as $1 / \mathrm{k}$.

$$
{ }^{\text {Rate }} \mathrm{CO}_{2}(t)=k \cdot A \cdot \exp ^{(-k T)}
$$

where: ${ }^{\text {Rate }} \mathrm{CO}_{2}(t)$ is the rate of $\mathrm{CO}_{2}$ efflux at time $t\left(\% \mathrm{~min}^{-1}\right), k$ is the decomposition rate of glucose $\left(\min ^{-1}\right)$, and $A$ is the size of the glucose pool at time $0(\%)$. 
To calculate MRT of $\mathrm{C}$ originating from sugars and incorporated into MB and SOM, the parameters of double exponential kinetics (Eq. 2) were fitted on all data from database II. Only the experiments with a duration $<1$ year were considered here.

$$
C_{x}(t)=A \cdot \exp ^{\left(-k_{1} T\right)}+(90-A) \cdot \exp ^{\left(-k_{2} T\right)}
$$

where: $C_{x}(t)$ is the pool size of glucose $\mathrm{C}$ at time $t$ (\% of applied tracer), $A$ is the size of the glucose $\mathrm{C}$ pool (\%), 90 is a percentage of glucose $\mathrm{C}$ immediately after the incorporation of glucose into $\mathrm{MB}$ (\% from applied tracer). 90\% (not 100\%) was taken as the pool of glucose C incorporated into MB because our database showed the direct decomposition of $10 \%$ of added glucose to $\mathrm{CO}_{2}$, which does not participate in the further utilization within the MB pool. $k_{1}$ and $k_{2}$ are decomposition rates of glucose $\mathrm{C}\left(\mathrm{min}^{-1}\right)$. The MRT of the glucose C incorporated into MB and SOM was calculated as $1 / \mathrm{k}$.

Assuming that MB is a main sink of sugar $\mathrm{C}$ in soil (see below), the ${ }^{14} \mathrm{C}$ or ${ }^{13} \mathrm{C}$ from sugars in SOM presents the sum of the label in living and dead MB. Thus, the part of $\mathrm{C}$ from sugars in the composition of dead MB was calculated by subtracting ${ }^{14} \mathrm{C}$ (or ${ }^{13} \mathrm{C}$ ) in $\mathrm{MB}$ from ${ }^{14} \mathrm{C}$ (or ${ }^{13} \mathrm{C}$ ) in SOM.

Statistica 10.0 (StatSoft Inc.) was used to fit parameters for the single and double exponential kinetics described above.

\section{Sources of sugars in soil}

\subsection{Primary sources of sugars}

\subsubsection{Plant sugars - input by decomposition of above- and belowground litter}

Plant biomass, including above- and belowground litter, is the main primary source of carbohydrates in soil. Cellulose consists mainly of glucose, whereas hemicelluloses include the rests of various pentoses and hexoses: glucans, xylans, mannans, galactans, fructosanes, arabinogalactans, with abundant pentoses (arabinose and xylose) (Table 7-1). Some plant species contain significant amounts of galactose and mannose (Sariyildiz and Anderson, 2003; Schaedel et al., 2010). 
Table 7-1. Composition of sugars in plants (\% from total sugars in the plant organs).

\begin{tabular}{|c|c|c|c|c|c|c|c|c|c|}
\hline Plant type & $\begin{array}{c}\text { Source of } \\
\text { sugars }\end{array}$ & Glucose & Mannose & Galactose & Rhamnosa & Fucose & Fructose & Arabinose & Xylose \\
\hline \multirow{3}{*}{$\begin{array}{l}\text { Deciduous } \\
\text { trees }\end{array}$} & Leaves & 3.0 & 3.2 & 25.7 & 7.0 & 2.2 & n.a. & 20.4 & 41.3 \\
\hline & Sapwood & 4.0 & 3.0 & 4.0 & 3.0 & 1.0 & n.a. & 6.0 & 78.0 \\
\hline & Bark & 3.0 & 2.0 & 13.0 & 3.0 & 2.0 & n.a. & 26.0 & 50.0 \\
\hline \multirow{4}{*}{$\begin{array}{c}\text { Coniferous } \\
\text { trees }\end{array}$} & Niddles & 16.3 & 31.5 & 19.2 & 2.4 & 1.4 & 3.5 & 23.4 & 13.1 \\
\hline & Roots & 19.4 & 5.8 & 20.8 & 4.2 & 2.8 & 0.5 & 23.8 & 22.7 \\
\hline & Sapwood & 5.0 & 17.0 & 25.0 & 2.0 & 1.0 & n.a. & 20.0 & 30.0 \\
\hline & Bark & 4.0 & 10.0 & 15.0 & 4.0 & 2.0 & n.a. & 49.0 & 18.0 \\
\hline \multirow{2}{*}{ Grasses } & Leaves & 6.4 & 1.0 & 6.5 & 1.2 & 0.9 & 0.7 & 19.4 & 63.5 \\
\hline & Roots & 6.8 & 3.0 & 11.3 & 2.0 & 1.4 & 0.6 & 18.7 & 55.3 \\
\hline \multirow{2}{*}{ Herbs } & Leaves & 5.0 & 3.0 & 25.0 & 3.0 & 3.0 & n.a. & 23.0 & 35.0 \\
\hline & Roots & 14.0 & 2.0 & 13.0 & 2.0 & 2.0 & n.a. & 28.0 & 38.0 \\
\hline
\end{tabular}

References: Sariyildiz and Anderson, 2003; Sariyildiz and Anderson, 2005; Schadel et al., 2010;

Nierop et al., 2001.

The green leaves contain 15-35\% cellulose and 20-40\% hemicellulose (Fig. 7-1). Cellulose is relatively enriched in forest litter (except coniferous trees), agricultural crops and grasses compared to green leaves (Fig. 7-1) (Salamanca et al., 2003; Sariyildiz and Anderson, 2005). Roots tissues contain 2-3 times more cellulose than green leaves (Fig. 7-1) (Zhang et al., 2014).

Cellulose decomposition in soil is estimated to range from $30 \%$ during 3 months (Blagodatskaya et al., 2014) to 50-86\% during two years (Zech et al., 2012). The lowest MRT for intact cellulose ranges from 0.6-1.1 $\mathrm{y}^{-1}$, depending on the type of litter (recalculated from (Fioretto et al., 2005)). Decomposition of intact hemicellulose is faster than cellulose and amounted to $70 \%$ during 7 months (Cheshire, 1979). These rates show that most of the celluloses and hemicelluloses will be decomposed to their monomers - sugars - within a few months. 


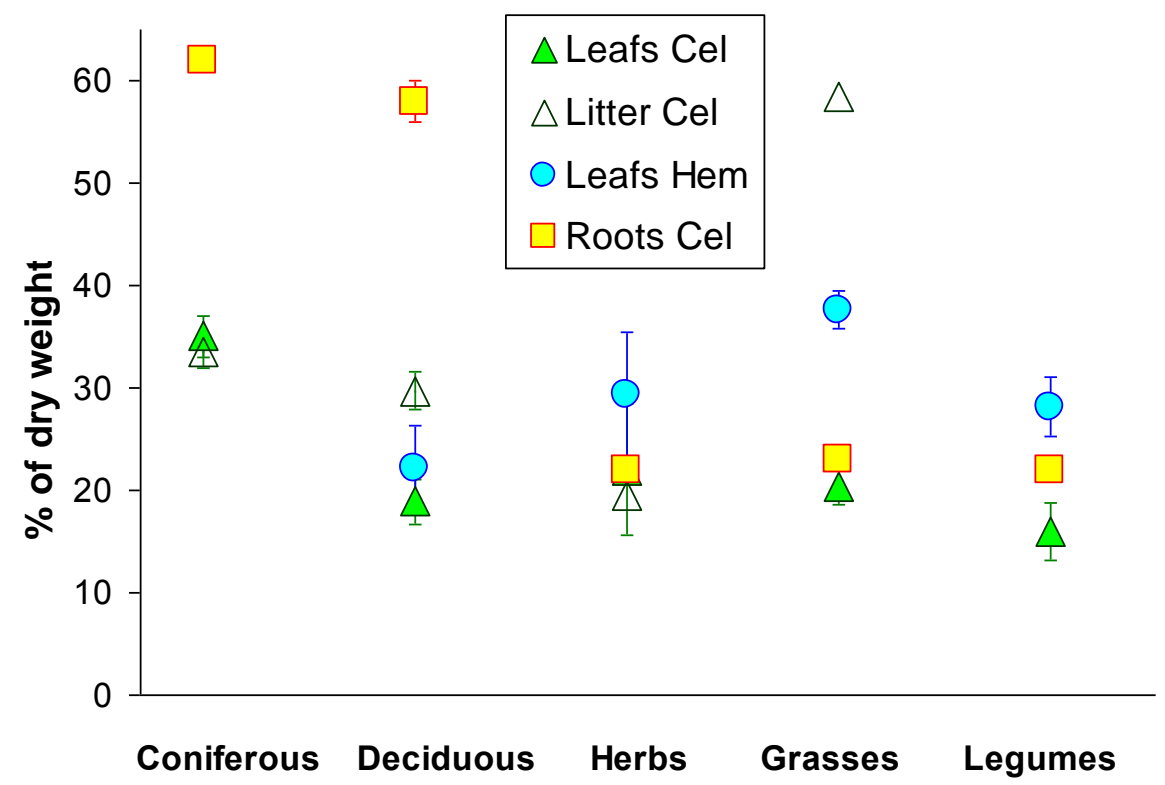

Figure 7-1. Average content of cellulose (Cel) and hemicellulose (Hem) in green leafs, litters and roots of main plant groups (\% of dry weight). Coniferous species (leafs cel $n=2$; litter cel $n=5$; roots cel $n=2$ ); deciduous species (leafs cel $n=5$; litter cel $n=6$; leafs hem $n=5$; roots cel $n=3$ ); herbs (leafs cel $n=6$; litter cel $n=1$; leafs hem $n=4$; roots cel $n=1$ ); grasses (leafs cel $n=2$; litter cel $n=1$; leafs hem $n=2$; roots cel $n=1$ ); legumes (leafs cel $n=6$; leafs hem $n=6$; roots cel $n=1$ ). (See references in Supplementary).

\subsubsection{Sugars in root exudates}

Plants release $15-40 \%$ of photosynthetically fixed $\mathrm{C}$ into the soil via rhizodeposition (Hutsch et al., 2002; Kuzyakov and Domanski, 2000; Warembourg and Estelrich, 2000). Among the numerous components exuded by roots, carbohydrates are the most abundant (Derrien et al., 2004; Hutsch et al., 2002; Kraffczyk et al., 1984). In root exudates, carbohydrates are present mainly in the form of monosacharides, whereas in secretions mainly as polysaccharides, e.g. mucilage (Meharg, 1994). Sugars account for 46-52\% in the exudates of wheat, alfalfa and pea plants, whereas they comprise only $15 \%$ in the exudates of oil radish and Chenopodium album (Hutsch et al., 2002). The dominant sugars in root exudates are glucose, fructose, galactose, arabinose, maltose, raffinose, rhamnose, sucrose and xylose (Grayston and Campbell, 1996). Glucose is common in root exudates of various trees species, whereas arabinose and ribose are absent (Grayston and Campbell, 1996). Glucose makes up the main part of root exudates $~ 40-50 \%$, whereas fructose, saccharose and ribose presented 23, 23 and 8\%, respectively (Hutsch et al., 2002).

$\mathrm{C}$ in root exudates is easily available for microorganisms and a major part of it (64-86\%) is decomposed to $\mathrm{CO}_{2}$. About 2-5\% of $\mathrm{C}$ released by roots to the soil is accumulated in the SOM (Helal and Sauerbeck, 1989; Hutsch et al., 2002). 


\subsection{Secondary sources of sugars}

\subsubsection{Sugars in soil organisms}

Soil microorganisms are the secondary source of carbohydrates in soil, i.e. microorganisms synthesize their sugars from the sugar $\mathrm{C}$ or other $\mathrm{C}$-containing substances derived from plant litter. Earlier studies showed that microbially derived polysaccharides predominantly consist of hexoses, mainly glucose, mannose and galactose (Oades, 1984). Later studies, however, demonstrated that soil bacteria, actinomyces and also pure cultures of bacteria or fungi contain considerable portions of pentoses, mainly ribose (Table 7-2).

Soil fauna can be an additional source of sugars into the soil. Earthworm cast and mucus are enriched with polysaccharides (Guggenberger et al., 1996; Pan et al., 2010; Zhang et al., 2009). Excretes of other insects (like plant louse), feeding on leafs, contain high sugar amounts. However, the contribution of this source to the total input of sugars compared to that of plants (primary source) and microorganisms (secondary source) is comparatively low.

Table 7-2. Composition of sugars in microorganisms (\% from DW).

\begin{tabular}{|c|c|c|c|c|c|c|c|}
\hline Microorganisms & $\begin{array}{c}\text { Source of } \\
\text { sugars }\end{array}$ & Glucose & Rhamnose & Mannose & Galactose & $\begin{array}{c}\text { Arabinose } \\
+ \text { Fucose + } \\
\text { Fructose }\end{array}$ & Ribose \\
\hline \multicolumn{8}{|l|}{ Pure cultures } \\
\hline \multirow{2}{*}{ Bacillus subtilis } & Cell & 45.9 & 4.3 & 8.9 & 26.2 & n.a. & 14.8 \\
\hline & EPS $^{1}$ & 10.1 & n.a. & 89.9 & n.a. & n.a. & n.a. \\
\hline Pseudomonas & Cell & 42.0 & 37.0 & 4.6 & n.a. & n.a. & 16.3 \\
\hline fluorescens & EPS & 17.7 & 18.4 & 58.4 & 4.5 & n.a. & 1.0 \\
\hline \multicolumn{8}{|c|}{ Microbial groups extracted from soil ${ }^{2}$} \\
\hline \multirow{2}{*}{ Bacteria } & Cell & 33.1 & 13.5 & 5.7 & 13.5 & 5.3 & 29.1 \\
\hline & EPS & 6.5 & 0.2 & 96.6 & 1.2 & 0.6 & 0.3 \\
\hline \multirow{2}{*}{ Actinomyces } & Cell & 13.6 & 6.5 & 41.4 & 16.0 & 10.7 & 11.8 \\
\hline & EPS & 1.3 & n.a. & 97.9 & 0.4 & 0.1 & 0.2 \\
\hline Fungi & Hyphae & 97.1 & n.a. & 0.7 & 1.2 & 1.1 & n.a. \\
\hline
\end{tabular}

${ }^{1}$ EPS - extracellular polysaccharides, Cell - cell compounds, n.a. - data not available

${ }^{2}$ Microbial groups have been selected from the andosols.

References: Tanaka et al., 1999. 


\subsubsection{Sugars in dissolved organic matter}

Dissolved organic matter (DOM) is a small part of SOM, but DOM is an important source of carbohydrates, mainly mono- and oligosaccharides. Sugars in DOM originated from the decomposition of plant litter (above- and belowground), root exudates and decomposition of SOM. They also contain sugars released by living and from dead microorganisms. The monosaccharide concentration in DOM varies from 5 to $130 \mathrm{mg} \mathrm{C} \mathrm{kg}^{-1}$ soil depending on ecosystem, which presents around 30\% of C in DOM (Fischer et al., 2007; Hishi et al., 2004; Tian et al., 2010). The main component (30\%) of sugars in DOM is glucose (Fischer et al., 2007).

\section{Content, composition and source of sugars in soil}

\subsection{Extraction and analysis of soil sugars}

Carbohydrate identification in soil involves several steps: extraction, purification and analysis of composition and amounts. This review does not examine all methodological details of sugar extraction from soil, their purification and analysis. Here, we merely briefly provide the extraction approaches for clearly separating the groups of carbohydrates in soil.

Based on the extractions and pretreatments, the following groups of sugars can be distinguished (Table 3): cellulose, non-cellulose (Murata et al., 1999), NaOH-extractable, inorganic salt-extractable (Badalucco et al., 1992; Hofman and Dusek, 2003; Joergensen et al., 1996), hot(Oades and Wagner, 1970) and cold-water extractable. Only independent extractions (not the sequential) are briefly described below.

Carbohydrates that are extracted by various water solutions - cold and hot water, salt and alkali (Table 7-3) - represent the easily available carbohydrate pool, consisting mainly of monoand oligosaccharides. Monosaccharides can be released from these extracts by hydrolysis with 0.5 $\mathrm{M} \mathrm{H}_{2} \mathrm{SO}_{4}$ (Tanaka et al., 1990).

Non-cellulose sugars can be extracted by diluted acids such as $2.5 \mathrm{M} \mathrm{H}_{2} \mathrm{SO}_{4}$ (Cheshire, 1979), $1 \mathrm{M} \mathrm{HCl}$ (Uzaki and Ishiwatari, 1983) or 4 M TFA (Amelung et al., 1996; Zhang et al., 2007) (Table 3).

Cellulosic sugars are extracted by two-step hydrolysis: 1) with cold $12 \mathrm{M} \mathrm{H}_{2} \mathrm{SO}_{4}$ (or $24 \mathrm{M}$ $\mathrm{H}_{2} \mathrm{SO}_{4}$, (Cheshire and Mundie, 1966) and 2) high-temperature hydrolysis with 6-12 $\mathrm{N} \mathrm{H}_{2} \mathrm{SO}_{4}$ to extract the maximum amount of sugars, including that in cellulose (Amelung et al., 1996; Cheshire and Mundie, 1966) (Table 3). Cold concentrated acids enable dissolving insoluble polysaccharides (in a cellulose composition) before hydrolysis. 
To purify the extracts from the humic-like compounds, various sorbents (XAD-4, C-18, activated carbon) as well as a combination of XAD-7 with cation exchange resin are applied (Amelung et al., 1996). The obtained monosaccharides are derivatized for quantitative analysis by gas chromatography (reviewed in detail by (Rodriguez-Sanchez et al., 2011)).

Finally, the extracted sugars can be identified and quantified spectrophotometrically (Doutre et al., 1978), by gas chromatography (GC) (Zhang et al., 2007), high-performance liquid chromatography (HPLC) (Tanaka et al., 1990) or ion chromatography (Martens and Loeffelmann, 2002). Spectrophotometric determinations with the phenol-sulfuric acid (Doutre et al., 1978; Martens and Frankenberger, 1990) or anthrone-sulfuric acid (Grandy et al., 2000) are used to estimate the total amount of sugars. The HPLC and GC allow further detailed quality and quantity identification of sugars (Basler and Dyckmans, 2013) to clarify their sources and fates in soil. 
Table 7-3. Carbohydrate groups extracted from soil by various solutions. The groups are presented for single and not for sequential extractions.

\begin{tabular}{|c|c|c|c|}
\hline $\begin{array}{l}\text { Groups of carbohydrates } \\
\text { (and average contribution } \\
\text { to total carbohydrates) }\end{array}$ & $\begin{array}{l}\text { Extraction } \\
\text { solution }\end{array}$ & Uncertainties $^{\top}$ & $\begin{array}{l}\text { Refe- } \\
\text { rence }\end{array}$ \\
\hline $\begin{array}{l}\text { Monosaccharides ( } 0.1 \% \text { from } \\
\text { total sugars in soil), } \\
\text { oligosaccharides, and non- } \\
\text { structural polysaccharides ( } 1 \%)\end{array}$ & Cold $\mathrm{H}_{2} \mathrm{O}$ & $\begin{array}{l}\text { Heterogenic mix of sugars from } \\
\text { microorganisms, SOM and plants. }\end{array}$ & 1,2 \\
\hline $\begin{array}{l}\text { Exocellular polysaccharides of } \\
\text { microbial origin }(10 \%)\end{array}$ & Hot $\mathrm{H}_{2} \mathrm{O}$ & $\begin{array}{l}\text { Co-extraction of plant polysaccharides } \\
\text { can occur }\end{array}$ & $\begin{array}{l}3,4, \\
5\end{array}$ \\
\hline $\begin{array}{l}\text { Microbial cellular } \\
\text { polysaccharides; Potentially } \\
\text { available of microorganisms }\end{array}$ & $\begin{array}{l}\text { Inorganic salts or } \\
0.5 \mathrm{M} \mathrm{K}_{2} \mathrm{SO}_{4}\end{array}$ & $\begin{array}{l}\text { Co-extraction of non-microbial-derived } \\
\text { sugars can occur after fumigation }\end{array}$ & $\begin{array}{l}6,7 \\
8\end{array}$ \\
\hline $\begin{array}{l}\text { Mix of sugars from humic and } \\
\text { fulvic acids and plant residues }\end{array}$ & $0.1 \mathrm{M} \mathrm{NaOH}$ & $\begin{array}{l}\text { Heterogenic mix of sugars of unknown } \\
\text { sources, Co-extraction of humic and } \\
\text { fulvic acids }\end{array}$ & 1,4 \\
\hline Non-cellulose sugars & $\begin{array}{l}\text { 1) } 0.5 \mathrm{M}_{2} \mathrm{SO}_{4} \\
\text { 2) } 2.5 \mathrm{M} \mathrm{H}_{2} \mathrm{SO}_{4} \\
\text { 3) } 1 \mathrm{M}, 6 \mathrm{M} \mathrm{HCl} \\
\text { 4) } 4 \mathrm{M} \mathrm{TFA}\end{array}$ & $\begin{array}{l}\text { Sugars from polysaccharides } \\
\text { (hemicellulose, cellulose) and } \\
\text { microorganisms }\end{array}$ & $\begin{array}{l}1,9 \\
10\end{array}$ \\
\hline Total sugars $(100 \%)$ & $\begin{array}{l}12 \mathrm{M} \mathrm{H}_{2} \mathrm{SO}_{4}+1 \\
\mathrm{M} \mathrm{H}_{2} \mathrm{SO}_{4}\end{array}$ & $\begin{array}{l}\text { Sugars from hemicellulose and cellulose, } \\
\text { also sugars from humic acids, } \\
1 / 3 \text { of sugars is lost due to hydrolysis }\end{array}$ & 11 \\
\hline
\end{tabular}

${ }^{1}$ Main uncertainties of the approaches are shortly described.

References: 1: Tanaka 1990; 2: Benzing-Durdue 1980; 3: Oades 1970; 4: Ball et al., 1996; 5: Haynes, 1993; 6: Badalucco et al., 1992; 7: Joergensen et al., 1996; 8: Hofman and Dusek 2003; 9: Murata et al 1999; 10: Amelung, 1996; 11: Cheshire and Mundie, 1966. 


\subsection{Sugar amounts and composition in soil}

\subsubsection{Total sugars}

According to the first database, sugar C content increases linearly with SOM content (Fig. 72, top). Previous reviews based on a much smaller database found linear or quadratic relationships between the sugar C and SOM contents in uncultivated soils (Folsom et al., 1974). The regression line (Fig. 7-2, top) clearly shows that sugars in their original structure (not the $\mathrm{C}$ metabolized by microorganisms to other substances) contribute $10 \pm 5 \%$ to SOM. This portion is similar for all soils with a clay content exceeding $15 \%$. Our large dataset, however, revealed that the portion of sugar C in sandy soils is less and accounts for only about 7\% of SOM (Fig. 7-2, bottom left). Similar trends were obtained for the non-cellulose sugars (Fig. 7-1, supplementary).

Grassland and cropland soils have the same portion of total sugar C in SOM, namely $10 \pm$ $5 \%$ (Fig. 7-2, bottom right). Forests soils have a 2.5 times higher contribution of sugar C to SOM $\left(\mathrm{R}^{2}=0.99\right)$. Nonetheless, the number of studies on total sugar content in forest soils is strongly limited and this high contribution should therefore be taken with caution.

Long-term cultivation ( 40 years) decreases carbohydrate $\mathrm{C}$ content similarly to SOM content (Bongiovanni and Lobartini, 2006; Dalal and Henry, 1988; Dormaar, 1994). Twenty-five years of forest disturbance causes carbohydrate loss from the organic horizon, whereas sugar stabilization was observed in the upper mineral horizons (Spielvogel et al., 2007).

Thus, the contribution of sugar C to SOM is very stable and amounts to about $10 \pm 5 \%$. Consequently, all land use changes and management practices affecting total SOM content have similar effects on the sugar content in soil. 

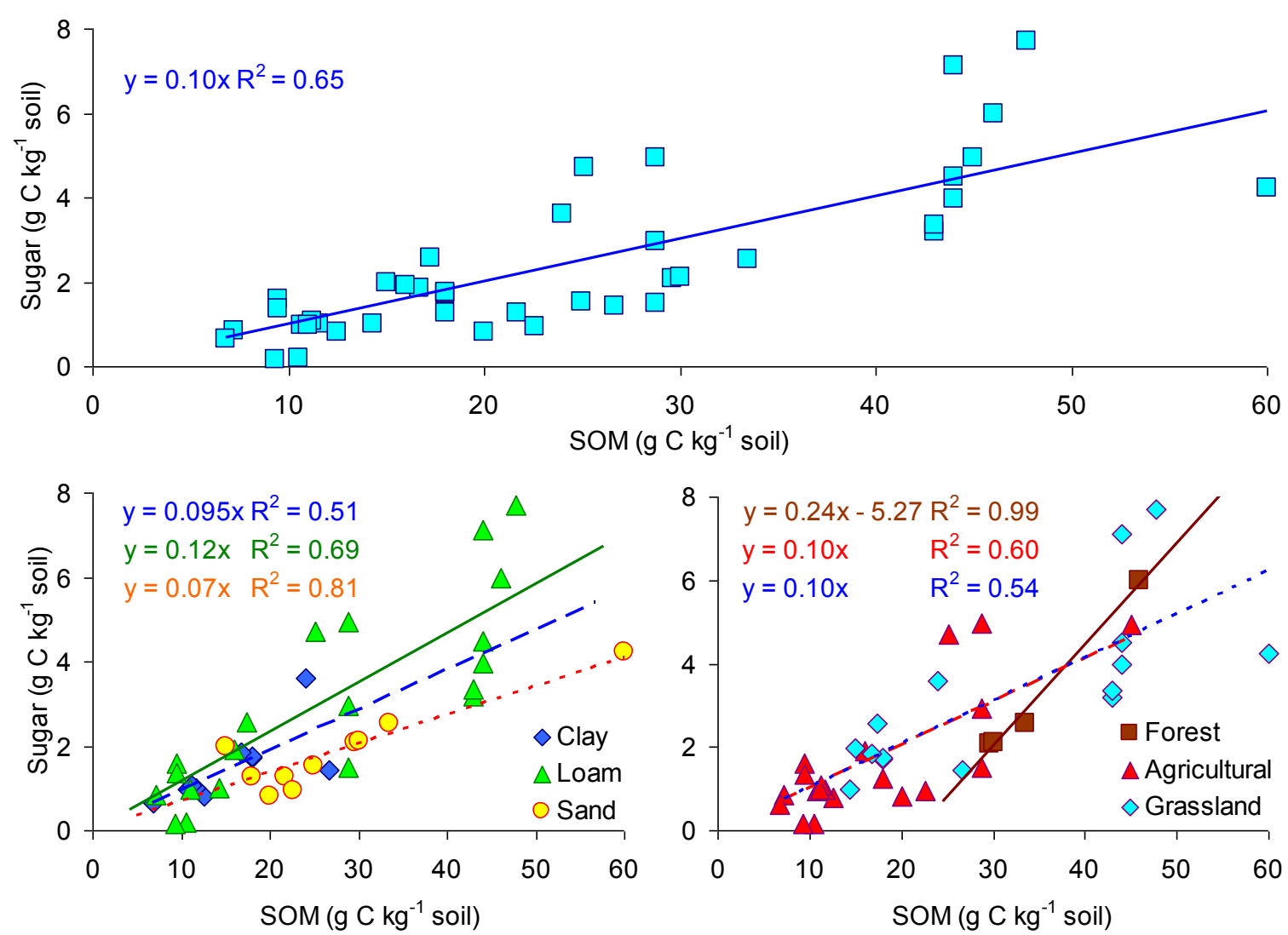

Figure 7-2. Total sugar C content depending on: SOM (top), soil texture (bottom left), plant functional types (bottom right). Left and right bottom graphs are created with the same data, but left graph accounts only soil textures and right graph accounts only plant functional types. All regression lines are significant at least by $p<0.05$. Because the intercepts in the most regression lines were not significantly different from 0, the intercept were fixed as 0 ((except for forest). (See references in Supplementary).

\subsubsection{Hexoses and pentoses in soil}

Hexoses dominate over pentoses in soils (Fig. 7-3) because: 1) hexoses originate from microorganisms and partly from plants, 2) the synthesis of hexoses by microorganisms is much higher than that of pentoses. This already reflects the importance of microbial synthesis and recycling of sugars for their composition in soil (see below).

Even though plant litter components are rapidly decomposed, considerable amounts of pentoses are accumulated in SOM (Fig. 7-3, the inset). Pentose accumulation in soil occurs due to the selective decomposition of plant polymers (Cheshire et al., 1971). 


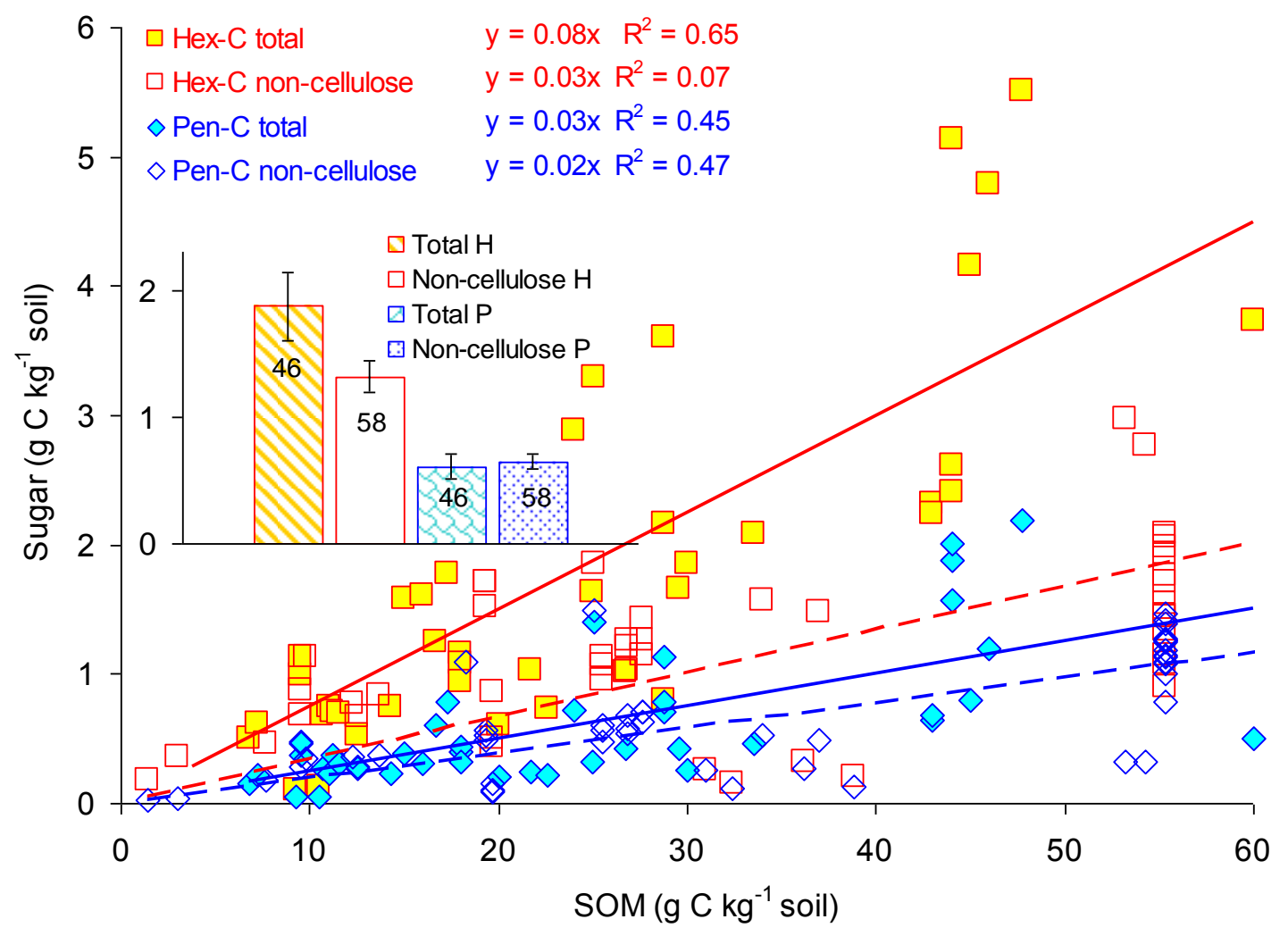

Figure 7-3. Cellulose and non-cellulose hexoses and pentoses depending on SOM content. Solid lines reflect significant regressions ( $p<0.05$ ) (total hexoses and pentoses); dashed lines reflect nonsignificant trends (non-cellulose hexoses and pentoses). The insert shows the average content of total and non-cellulose hexoses (Hex) and pentoses (Pen) in soils. The numbers on the columns represent the number of individual values for the average. Hexoses were calculated as a sum of glucose, galactose, mannose, rhamnose and fucose. Pentoses were calculated as a sum ribose, arabinose and xylose. (See references in Supplementary).

Glucose is the dominant hexose overall and in the non-cellulose sugars (Fig. 7-4, top). The contents of galactose, mannose and rhamnose are similar, but 1.5-2 times lower than that of glucose. The fucose content is even 5 times lower than glucose. Arabinose and xylose are the dominant pentoses, with almost equal contents.

1.5 times more glucose, rhamnose, ribose and fucose are obtained from the soil by total sugar extraction versus extraction of non-cellulose sugars (Fig. 7-4, top). In general, the amount of pentoses is comparable with the amount of all hexoses except glucose. The highest amount of glucose compared to other sugars is explained by its diverse origins: i) from the decomposed cellulose of plant residues, ii) released by living roots, and iii) synthesized by microorganisms. 
The same sugars are dominated in the hot-water extracts, but the content is 10-20 times lower than in total sugars. Cold-water extracts 10 times less sugars than hot water without any preference for distinct sugars (Fig. 7-4, bottom).

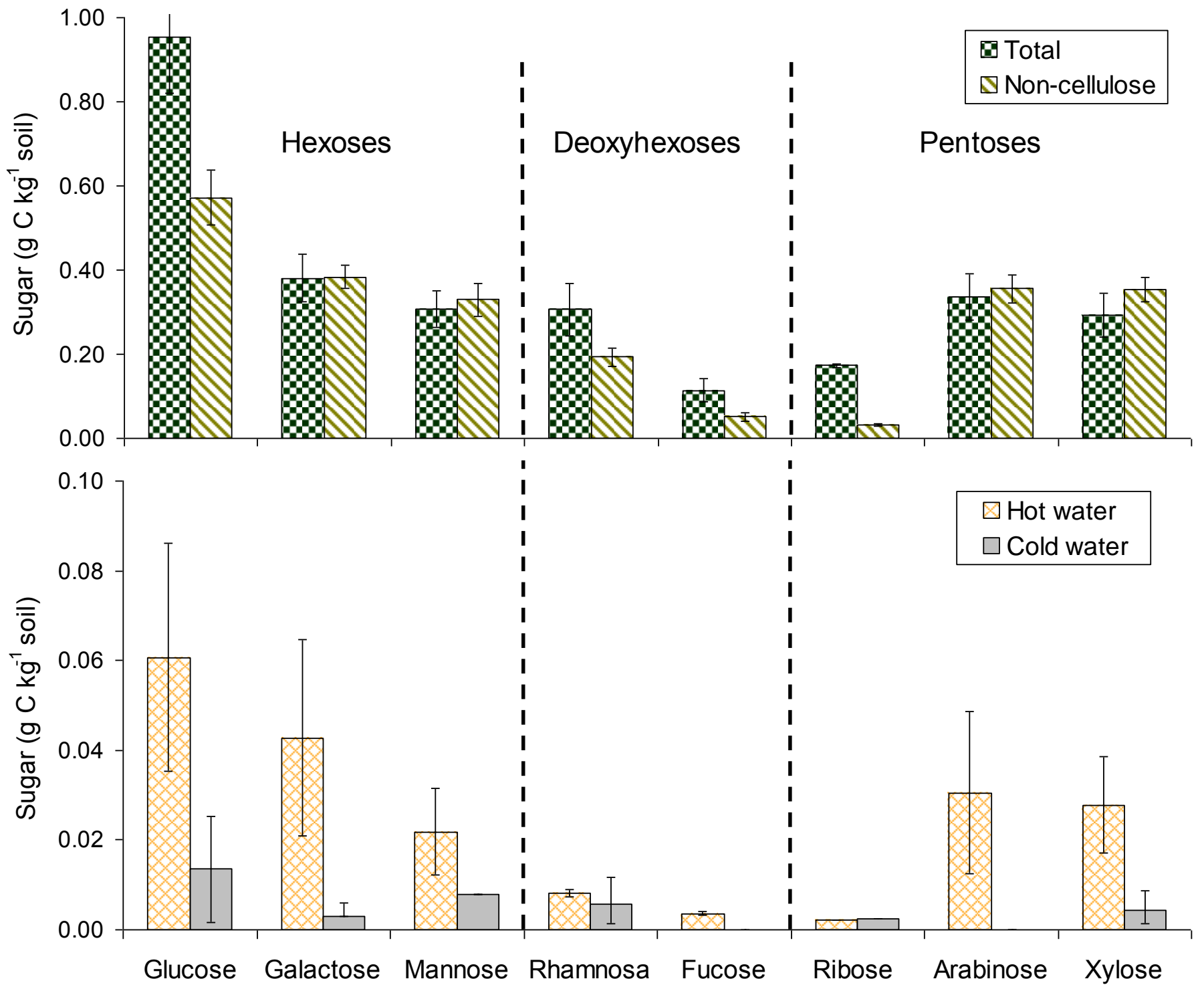

Figure 7-4. Content of total and non-cellulose hexoses and pentoses in soils (top) and in hot and cold water extracts (bottom). Mean \pm SE. (See references in Supplementary). 


\subsubsection{Plant and microbial origin of sugars in soil}

The mixing of various sugar sources makes it difficult to determine whether their origin is from plants or from microorganisms. Microorganisms synthesize mainly hexoses (glucose, mannose, galactose) (Oades, 1984). Pentoses, especially arabinose and xylose, are not synthesized by microorganisms in relevant amounts (except by the low-temperature yeasts) and are present mostly in plant residues (Cheshire et al., 1990). Therefore, the ratio GM/AX is used to identify the origin of carbohydrates in soil. The GM/AX ratio for non-cellulose sugars in soil varies from $0.5-2$, whereas values $<0.5$ are common for plant polysaccharides, and $>2$ is typical for microbial polysaccharides (Oades, 1984). This ratio showed that hot-water extractable sugars mainly originate from microorganisms (Haynes and Francis, 1993), whereas $\mathrm{NaOH}$-extractable sugars are from plant litter (Ball et al., 1996).

Evaluation of the first database showed the lowest GM/AX ratio (calculated for noncellulose sugars) in soils under grasses and the highest under trees (Fig. 7-5). This ratio for the green leaves of trees ranges from 0.5 to 1.4, and consist 0.09 and 0.5 for grasses and crops, respectively (Fig. 7-5). Thus, the high GM/AX ratio in forest soils is not due to a high contribution of sugars of microbial origin as supposed earlier, but reflects the high hexose content in the tree litter (mainly mannans). In contrast, the low ratio points to a higher input of microbial than plant residues to sugar accumulation in soils under crops and grasses. Nonetheless, a high galactose fraction in some crops and grasses (corn and bromegrass) have been reported (Angers and Mehuys, 1990). This can also lead to overestimation of the microbial sugars within the SOM. To overcome these uncertainties, the mannose/arabinose+xylose (Angers and Mehuys, 1990), mannose/xylose (Hu et al., 1995), glucose/mannose (Benzingpurdie, 1980), rhamnose+fucose/arabinose+xylose (Spielvogel et al., 2007) ratios have been used to estimate the origin of soil sugars. We conclude that there is no universal ratio allowing correct determination the origin of soil sugars. The highest uncertainties occur due to high amounts of hexoses in plant residues, potentially overestimating the contribution of microbial residues calculated based on the GM/AX ratio. On average, specific GM/AX ratios for various vegetation types vary between 0.09 and 1.4. Thus, drawing a correct conclusion about the contribution of plant and $\mathrm{MB}$ residues to the origin of soil sugars requires first determining the GM/AX ratio for residues of local plant species. 


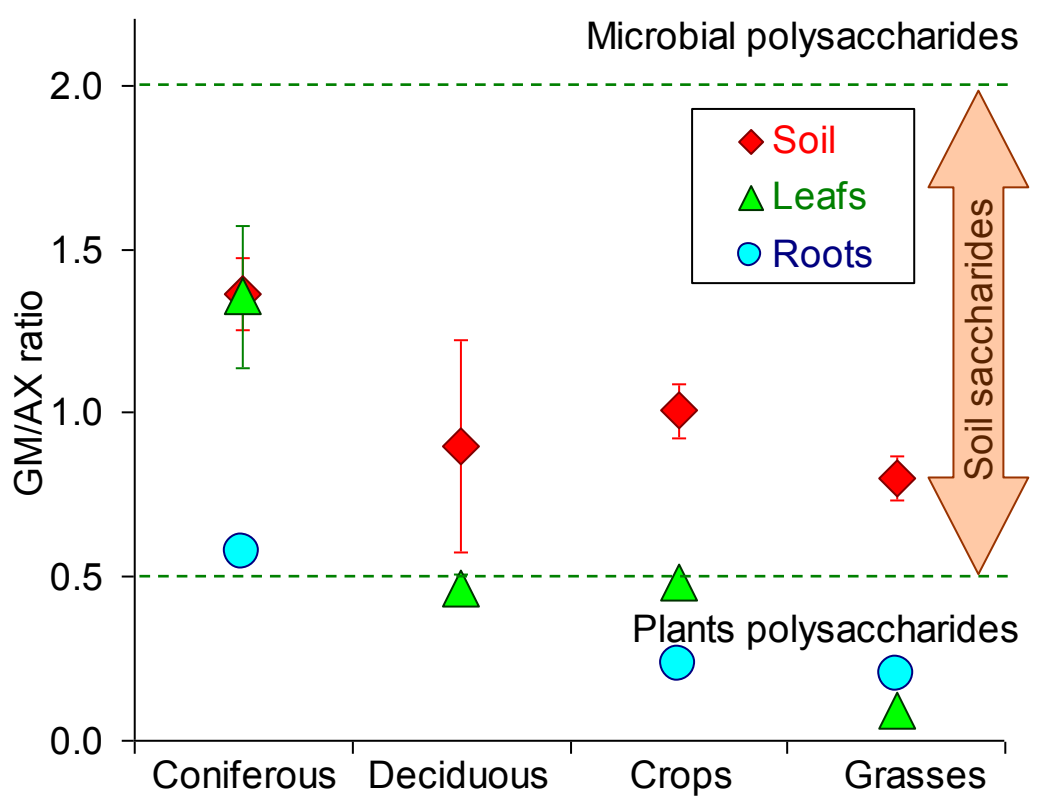

Figure 7-5. The ratios of galactose+mannose/arabinose+xylose (GM/AX) in microbial and plant polyssacharides and in non-cellulose sugars in soils developed under coniferous and deciduous trees, crops and grasses. The GM/AX ratios of 0.5 for plant and 2.0 for microbial posysaccharides (dashed lines) were taken from Oades et al. (1984). (See references in Supplementary).

\section{Fate of sugars in soil}

Similarly to all other substances, carbohydrates undergo various processes in soil (Fig. 7-6) including: 1) sorption by various soil components (organic matter, clay particles, sesquioxides), 2) leaching within DOM to deeper soil horizons, 3) uptake by plants, and 4) uptake and transformation by microorganisms including incorporation into metabolites and mineralization to $\mathrm{CO}_{2}$. We begin by briefly describing the abiotic processes $(1+2)$ and biotic processes $(3+4)$. 


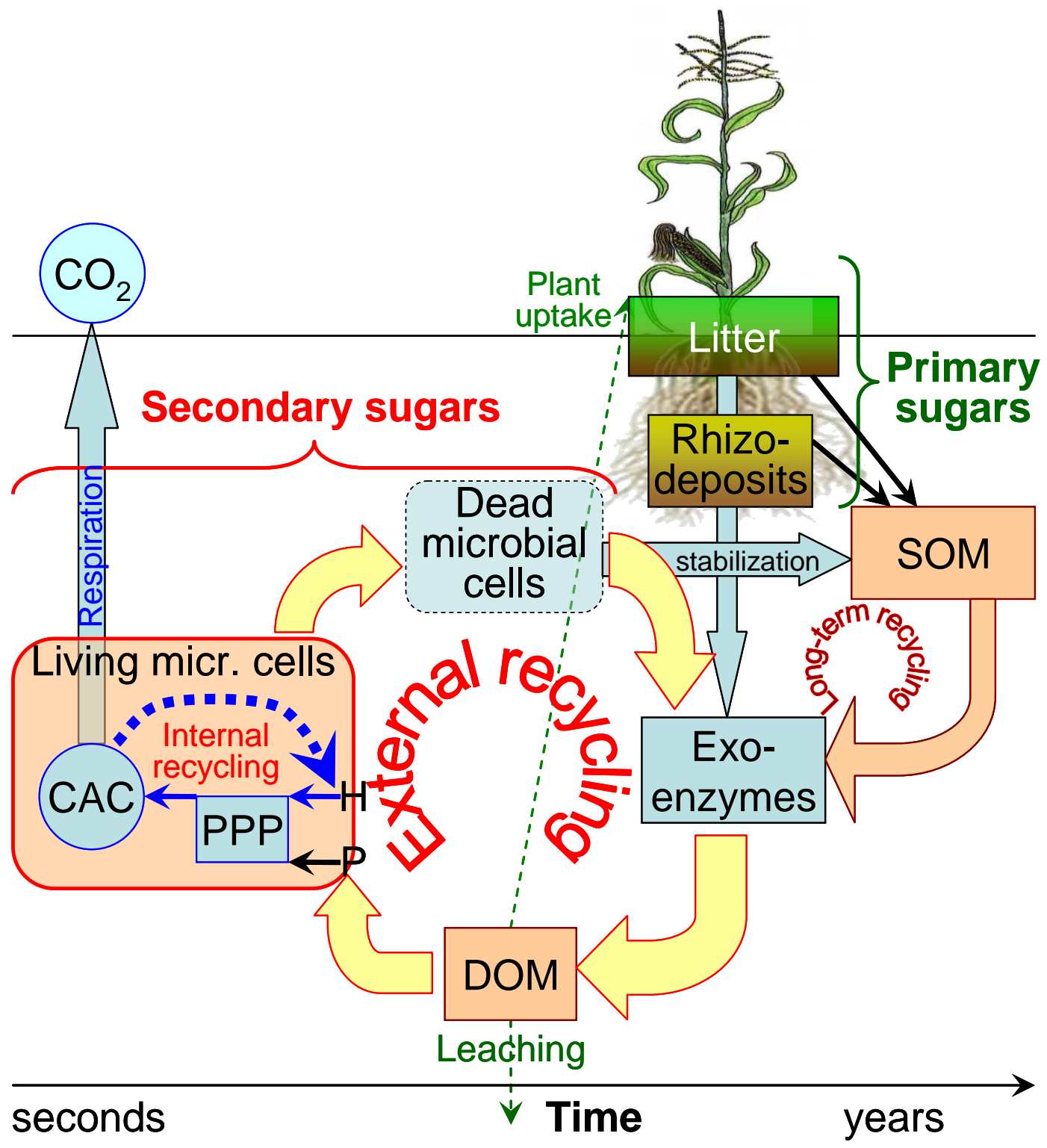

Figure 7-6. Fate of sugars in soil. Primary (plant derived) and secondary (microbially derived) inputs of sugars are presented. The importance of three recycling cycles is underlined: internal recycling within microbial cells (in blue, the rates are within seconds to minutes), short-term external recycling (in red, the rates are within weeks to months) and long-term external recycling (in braun, the rates are within months to years and decades).

SOM: soil organic matter, DOM: dissolved organic carbon, PPP: pentose phosphate pathway, $C A C$ : citric acid cycle, $H$ : hexoses, $P$ : pentoses. Note that the size of the boxes does not correspond to the amount of sugar $C$ in the pools. However, we tried to reflect the intensity of fluxes by the size of the arrows. 


\subsection{Abiotic processes}

\subsubsection{Sorption of carbohydrates on mineral and organic surfaces}

Firstly, the sorption of substances on mineral and organic particles is strongly connected with the surface charge or ability to form hydrophobic ligand interactions. Polysaccharides have neither surface charges nor hydrophobic groups and, therefore, their sorption is of minor importance. Similar to polysaccharides, monosaccharides have no charge and are neither zwitterions nor polar substances. Moreover, there are no significant functional groups by which sugars can be absorbed on the mineral surfaces. Only weak hydrogen bouns have been reported between glucose and goethite surface (Olsson et al., 2011).

Secondly, there is strong competition between sorption and microbial uptake (Fischer et al., 2010): the physicochemical sorption of glucose from the solution on the mineral soil surfaces reaches quasi-equilibrium within $400 \mathrm{~min}$, with only about $7-10 \%$ in the sorbed form. In contrast, nearly $100 \%$ of the glucose is taken up within a few minutes by microorganisms (Fig. 7-3 in (Fischer et al., 2010)). We therefore conclude that carbohydrate sorption in soil is a minor of importance for their fate.

\subsubsection{Leaching of carbohydrates from soil}

Carbohydrate movement within and leaching from the soil profile is possible with DOM. DOM contains mono-, di- and oligosaccharides (Kaiser and Kalbitz, 2012) in total concentrations of 2-3 $\mu \mathrm{M}$ (Fischer et al., 2010). Considering a water flux below the root zone of about $200 \mathrm{~mm}$ per year, the carbohydrate losses by leaching amount to about $480 \mu \mathrm{mol} \mathrm{m}{ }^{-2}$, which is negligible compared to their total input and microbial uptake (see below).

\subsection{Biotic processes of carbohydrate utilization}

\subsubsection{Sugars uptake by plants}

Plants are not only the primary source of carbohydrates, but also can take them up (in the form of sugars) from soil solution. Sugar uptake occurs from decomposed litter, microbial residues and SOM as well as reuptake of sugars released by roots in the rhizosphere (Kuzyakov and Jones, 2006a).

Up to $50 \%$ of the glucose ${ }^{14} \mathrm{C}$ may be taken up by plants from sterile hydroponics (Jones and Darrah, 1992). In contrast, studies under soil conditions showed that less than $1 \%$ of ${ }^{14} \mathrm{C}$ from glucose is taken up by roots (Biernath et al., 2008; Kuzyakov and Jones, 2006a). Such strong 
differences between hydroponics and soil conditions reflect the absence of competition between microorganisms and roots for sugar uptake in hydroponics (Kuzyakov and Jones, 2006b). In contrast, uptake by microorganisms under soil conditions is very fast and efficient. Accordingly, root uptake declines to a minimum $(<1 \%)$, which is not relevant for the fate of sugars in soil.

\subsubsection{Carbohydrate uptake and utilization by microorganisms}

The most microbially available carbohydrates in soil are mono-, di- and oligosaccharides, which originate from polysaccharides after enzymatic hydrolysis (Blagodatskaya et al., 2014; Cheshire, 1979). Besides the intracellular utilization by microorganisms, exoenzymes can split and partly mineralize carbohydrates before the uptake. The hypothesis is that exoenzymes function in soil independently of the microorganisms (Maire et al., 2013). Nonetheless, the specific mechanisms of exoenzyme reactions and especially their persistence and relevance for sugar decomposition still need to be clarified.

The rates of monosaccharide uptake by microorganisms range from seconds to minutes (Jones and Murphy, 2007). This makes microbial uptake by far the dominating process among all other processes determining the fate of sugars in soils. Microbial utilization of sugars includes three stages: 1) uptake, decomposition of initial substance and its mineralization to $\mathrm{CO}_{2}, 2$ ) incorporation of $\mathrm{C}$ into anabolism products and recycling within the living $\mathrm{MB}$, and 3) reuse of $\mathrm{C}$ from the components of microbial residues (Fig. 7-6). The most rapid stage is the first one (seconds to minutes) (Fig. 7-7), whereas the slowest is mineralization of dead microbial residues (from months to years, Fig. 7-8). Based on the $2^{\text {nd }}$ database, we reviewed these three stages of sugar utilization and calculated MRT of sugar $\mathrm{C}$ for each stage. Most of the estimations below reflect process rates with glucose because only very few studies are available about other sugars.

Correctly estimating sugar decomposition rates requires the data on the sugar concentration remaining in soil solution (Coody et al., 1986). Most studies, however, analyzed the ${ }^{14} \mathrm{CO}_{2}$ or ${ }^{13} \mathrm{CO}_{2}$ efflux, but not the remaining sugar in solution. Sugars are taken up very fast by microorganisms (from seconds to minutes) and decomposed immediately. We therefore estimated their mineralization rates using the data on $\mathrm{CO}_{2}$ emission for the very short time period after substance application. We used data on released ${ }^{14} \mathrm{CO}_{2}$ or ${ }^{13} \mathrm{CO}_{2}$ from added glucose only during the first $24 \mathrm{~h}$ (Fig. 7-7). Such a short period enabled calculating the initial sugar decomposition rate and the MRT of sugar $\mathrm{C}$ before its incorporation into cell compounds. The estimated maximum glucose $\mathrm{C}$ decomposition rate to $\mathrm{CO}_{2}$ was $1.1 \% \mathrm{~min}^{-1}$ (Fig. 7-7). At such high rates, half of the glucose $\mathrm{C}$ 
should be mineralized to $\mathrm{CO}_{2}$ within the first hour. The values in the $2^{\text {nd }}$ database showed that up to $80 \%$ of glucose $\mathrm{C}$ is still present in soil (not in soil solution) as metabolites after 1 day. This high percentage shows that the mineralization rate decreases dramatically after $\mathrm{C}$ incorporation into microbial cells. Based on Fig. 7-7 the estimated MRT of glucose C, before C is incorporated into microbial metabolites, is $34 \mathrm{~min}$. This means that the time needed for glucose to pass through the biochemical cycles within the cells is around $30 \mathrm{~min}$. As the glucose in the cell cycles is split into parts, the MRT time of glucose, as a whole molecule, during microbial metabolization is much shorter than $30 \mathrm{~min}$.

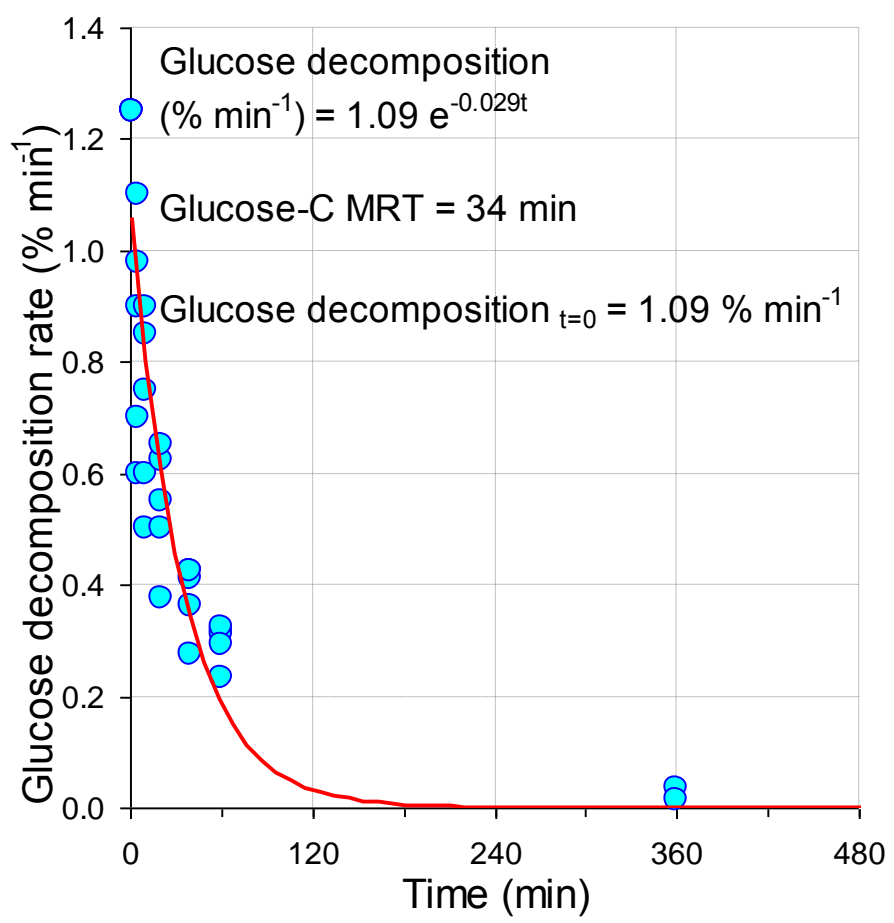

Figure 7-7. Rates of glucose mineralization in soil estimated based on ${ }^{14} \mathrm{CO}_{2}$ or ${ }^{13} \mathrm{CO}_{2}$ emission. These rates reflect the original glucose before its incorporation into microbial products. (See references in Supplementary). 


\subsection{External and internal recycling of sugar $C$}

The assessment of sugar production (Fig. 7-1) and utilization by microorganisms (Fig. 7-7) clearly shows the importance of microbial recycling in soil. It is comparatively simple to calculate the primary input of sugars into soil: it corresponds to the total primary production of the ecosystem multiplied by carbohydrate contents in the most important pools (above- and belowground plant biomass, and root exudates). However, it is very challenging to estimate the recycling of sugars because it occurs i) externally (outside of living microbial cells), and ii) internally (within microbial cells) (Fig. 7-6) and because the recycling cannot be assessed solely by input and output.

The simplest way to assess the external recycling of sugars is to use i) their content in the DOM pool (because only dissolved organics can be taken up and utilized by microorganisms), ii) sugar decomposition rates, and iii) assume a steady state of sugars in the DOM pool over longer periods. For this approach, the DOM can be understood as a main sink for the products of external recycling (Fig. 7-6). In contrast, we cannot assess the intensity of recycling in microbial cells, but will briefly mention the biochemical pathways of sugars within microorganisms.

\subsubsection{Fast external recycling of sugars and budgeting of input}

Fast external recycling includes the decomposition of i) carbohydrates from dead MB and ii) mono- and polysaccharides released by living MB (Fig. 7-6). Polysaccharides are decomposed by exoenzymes to oligo- and monomers and enter the DOM pool, where they can be further taken up by microorganisms or leached from the soil profile (small portion).

To estimate the total input of sugars into DOM, we assumed that their concentration in DOM is a nearly constant over a vegetation period (steady state conditions). Consequently, we calculated the amounts of annually decomposed sugars based on their content in the DOM pool and decomposition rates (calculated above according to $2^{\text {nd }}$ database, Eq. 1) using the following equation:

$$
\text { Pool }_{t+1}=\text { Pool }_{t}+\text { Input }- \text { Pool }_{t} \cdot k_{\text {Decomp }} \quad \text { Eq. } 3
$$

where, Pool is the pool of sugar C in DOM (mg C kg${ }^{-1}$ soil), Input is the input of sugar C into DOM ( $\mathrm{mg} \mathrm{C} \mathrm{kg}^{-1}$ soil $\mathrm{min}^{-1}$ ), and $k_{\text {Decomp }}$ is the decomposition rate of sugar $\mathrm{C}$ in DOM $\left(\% \mathrm{~min}^{-1}\right.$ ), and $t$ is time. According to the steady state, this decomposed amount corresponds to the input. $k$ was taken from the calculated glucose $\mathrm{C}$ decomposition rates $\left(k=0.03 \% \mathrm{~min}^{-1}\right.$, Fig. $\left.7-7\right)$, and sugar content (on the example of glucose $\mathrm{C}$ in soil solution) was taken as $22 \mathrm{mg} \mathrm{C} \mathrm{kg}^{-1}$ soil (Fig. 7-4). 
The total (primary and secondary) input of sugar C into DOM estimated by this approach was $0.0065 \mathrm{mg} \mathrm{C} \mathrm{kg}^{-1}$ soil $\mathrm{min}^{-1}$. The input for a half year (corresponding to a vegetation period) was $1.7 \mathrm{~g} \mathrm{~kg}^{-1}$ soil $(262,800$ (min in half of a year) *0.0065)/1000). Sugar C input on 1 ha soil was $5.1 \mathrm{Mg} \mathrm{C}$ half year $^{-1}\left(3 * 10^{6}(\mathrm{~kg}\right.$ soil in $\left.1 \mathrm{ha}) * 1.7\right)$. This input includes sugar $\mathrm{C}$ from the primary source (plant biomass) and from the secondary source (microbially recycled sugars).

For the estimation we calculated the possible input of sugar $\mathrm{C}$ from deciduous forests (Table 7-4) (Basilevich, 1993). We calculated the possible input of sugar C from plant biomass (primary source) into the soil considering 1) the annual plant biomass production, 2) the known percentage of cellulose, and 3) assuming that most sugar $\mathrm{C}$ enters the soil as cellulose. To calculate the cellulose portion in the above- and belowground plant biomass, we used the mean values from Fig. 7-1. The amount of root exudates has been calculated as $1 / 3$ of the root biomass (Kuzyakov and Domanski, 2000); the proportion of sugars in the composition of root exudates has been taken as $50 \%$ (Hutsch et al., 2002). Total input of glucose C from plant biomass has been calculated as the sum of aboveground and belowground plant biomass and root exudates. The comparison of sugar $\mathrm{C}$ input from plants (about 1.1 $\mathrm{Mg} \mathrm{C}^{-1} \mathrm{year}^{-1}$ ) with the calculated theoretical total input into DOM $(\sim 5.1 \mathrm{Mg} \mathrm{C})$ leads us to conclude that $4 / 5$ of sugars in DOM are sugars from the secondary source living microorganisms and microbial residues. The remaining $20 \%$ originate from plant biomass. We expect that portion of secondary sugar $\mathrm{C}$ will be even higher in ecosystems with higher temperatures because primary productivity increases with temperature slower than microbial turnover.

The very high portion $(\sim 80 \%)$ of the secondary sugars in soil strongly contradicts with the classical view on carbon use efficiency (CUE) (Lettau and Kuzyakov, 1999; Payne, 1970). Even if only one step of microbial recycling for sugar $\mathrm{C}$ is assumed, the CUE should be about 0.8, but this is nearly two fold higher than CUE values frequently reported for soil (Sinsabaugh et al., 2013). Assuming, that sugar C is recycled in soil more than once (Basler et al., 2015a; Basler et al., 2015b), the CUE should be close to 1.0. The discordance between very high efficiency of C recycling by soil microorganisms (not only of sugars (Hobbie and Hobbie, 2013 ) and the frequently reported low CUE values should be clarified in theoretical concepts and justified in experiments.

\subsubsection{Internal recycling and biochemical pathways of sugars within microorganisms}

Despite the high microbial demand for sugars, $\mathrm{C}$ from them is not mineralized to $\mathrm{CO}_{2}$ completely. Rather, part of the $\mathrm{C}$ undergoes intensive internal recycling. Therefore, sugar $\mathrm{C}$ is 
'stabilized' or actually stored in living MB. To estimate MRT of sugar C within MB, we applied the double exponential model to the data on ${ }^{13} \mathrm{C}$ or ${ }^{14} \mathrm{C}$ glucose incorporation into MB (Eq. 2). The first exponent was responsible for the fast-utilized $\mathrm{C}$, mainly allocated in the cytoplasm. The MTR of sugar $\mathrm{C}$ in $\mathrm{MB}$ calculated by $k 1$ (see Eq. 2) was $1.25 \mathrm{~d}$. The rate of the second exponent reflects the $\mathrm{C}$ incorporated into the stable cell components such as cell walls. MRT of $\mathrm{C}$ in that pool calculated by $k 2$ was $230 \mathrm{~d}$ (Fig. 7-8). Calculated glucose C MRT in MB is in accordance with estimated turnover times of bacterial (120-180 d) and fungal biomass (270 d) in soil (Moore et al., 2005; Rousk and Baath, 2007).

The main pathways of the glucose utilization by soil microorganisms are the pentose phosphate cycle and glycolysis (Embden-Meyerhof-Parnas). The latter is part of the Krebs cycle. These pathways of sugars within the cells are described in detail in microbial biochemistry (Lengeler et al., 1999) and will not be reviewed here. As a result of internal recycling, sugar C can be included into various metabolic products such as other sugars, carboxylic acids or amino acids and can be used to construct cell structural components including cell membranes and cell walls (Gunina et al., 2014), or cell polymers like DNA or RNA.

For internal recycling it is important that mainly glucose (hexoses, $\mathrm{H}$ in Fig. 7-6) will be produced within the gluconeogenesis (Apostel et al., 2015). Pentoses will be produced within internal recycling only to a very minor extent. This explains why microbially produced sugars consist nearly entirely of hexoses, and the pentoses (pentoses, P in Fig. 7-6) originate mainly from plant residues.

\subsubsection{Sugar C stabilization in SOM and long-term external recycling}

Together with decomposition, sugar $\mathrm{C}$ can be stabilized in the SOM pool and further participate in long-term external recycling (Fig. 7-6). There are two ways to stabilize sugar $\mathrm{C}$ in SOM: 1) stabilization within the composition of recalcitrant plant polymers such as cellulose means stabilization of the primary source, and 2) stabilization within the microbial residues means stabilization of the secondary source. Cellulose as well as dead MB are quite recalcitrant and, thus, $\mathrm{C}$ in these sources is preserved in the soil for long periods.

To estimate sugar $\mathrm{C}$ stabilization within the composition of recalcitrant plant polymers, we calculated the cellulose decomposition rates in the soil. We used the annual input of glucose with plant cellulose (approximately $1 \mathrm{Mg} \mathrm{C} \mathrm{ha}^{-1}=300 \mathrm{mg} \mathrm{C} \mathrm{kg}^{-1}$ soil, see Table 7-4) and the content of cellulose-derived glucose $\mathrm{C}$ in SOM composition (400 mg kg-1 Fig. 7-4) to calculate the rate of 
cellulose decomposition in soil. We assumed that the content of cellulose-derived glucose $\mathrm{C}$ in SOM (Fig. 7-4) is nearly constant over a vegetation period. The first-order kinetics was used:

$$
\text { Pool }_{t+1}=\text { Pool }_{t}+\text { Input }_{-P_{\text {Ool }}} \cdot k_{\text {Decompos }}
$$

where: Pool is the pool of cellulose sugar $\mathrm{C}\left(\mathrm{mg} \mathrm{kg}^{-1}\right)$ in SOM at time $t$ or $t+1$, Input is an input of cellulose ( $\mathrm{mg} \mathrm{C} \mathrm{kg}^{-1}$ soil) with plant biomass and $k_{\text {Decompos }}$ is the decomposition rate of cellulose (day ${ }^{-}$ $\left.{ }^{1}\right)$.

Table 7-4. Estimated glucose-C input from plants on the example of deciduous forest.

\begin{tabular}{|c|c|c|c|}
\hline $\operatorname{Mg~ha}^{-1} \mathrm{y}^{-1}$ & Above ground biomass & Below ground biomass & Root exudates \\
\hline Net primary production ${ }^{\text {a) }}$ & 6.1 & 1.4 & 0.5 \\
\hline Cellulose & 1.8 & 0.8 & n.a. \\
\hline Glucose-C & 0.7 & 0.3 & 0.1 \\
\hline \multicolumn{3}{|c|}{ Total input of glucose-C from plants $\left(\mathrm{Mg} \mathrm{C}^{-1} \mathrm{ha}^{-1}\right)$} & 1.1 \\
\hline
\end{tabular}

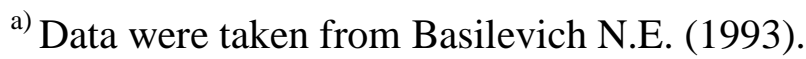

n.a. - not applicable.

The calculated decomposition rate of cellulose was 0.002 day $^{-1}$, and MRT of cellulose was $1.4 \mathrm{y}^{-1}$. The latter value is in the range of cellulose MRT reported in the literature (Blagodatskaya et al., 2014; Zech et al., 2012).

To estimate the portion of sugar $\mathrm{C}$ stabilized in microbial residues (stabilization in secondary source), we subtracted the percentage of sugar ${ }^{13} \mathrm{C}$ or ${ }^{14} \mathrm{C}$ incorporated into living $\mathrm{MB}$ from the percentage of sugar ${ }^{13} \mathrm{C}$ or ${ }^{14} \mathrm{C}$ remaining in SOM (Fig. 7-8). Here, we assumed that sugar $\mathrm{C}$ remaining in SOM consists of the sum of that in living MB plus in the composition of microbial residues (because other processes are negligible, see above). The sugar $\mathrm{C}$ in microbial residues already peaked on day 5 after glucose addition. It decreased rapidly up to day 15 and the further decrease was very slow (Fig. 7-8). The initial fast increase of sugar C in dead MB involves the release of metabolic products from microbial cells into the soil (Cheshire, 1979). The fast depletion of one third of the dead microbial pool reflects further microbial decomposition of metabolites to $\mathrm{CO}_{2}$ and is $\sim 500$ times slower than the initial sugar utilization. The slow decrease of sugar $\mathrm{C}$ in the pool of microbial residues reflects the dying $\mathrm{MB}$ and thus the slow degradation of sugar $\mathrm{C}$ incorporated into cell polymers (long-term external recycling). 
Thus, sugar $\mathrm{C}$ incorporated into the dead MB starts to dominate in SOM and determines the long-term MRT of sugar C in soil (Fig. 7-8). This corroborates the results of long-term experiments that applied ${ }^{14} \mathrm{C}$-labeled glucose into the soil: three years after glucose addition, $15-20 \%$ of ${ }^{14} \mathrm{C}$ were still present in SOM (Cheshire, 1979).

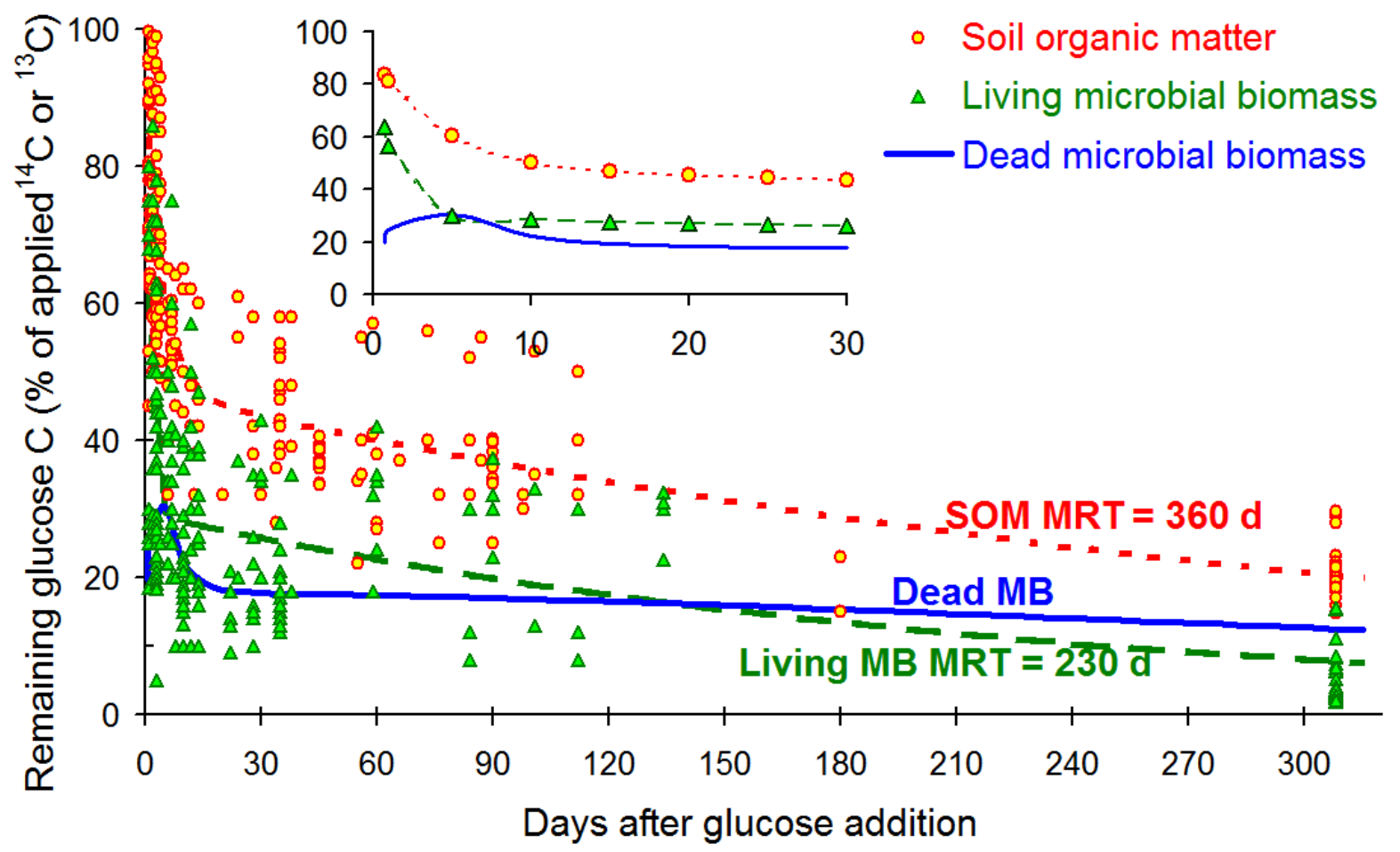

Figure 7-8. Dynamics and partitioning of glucose-C for three pools: living microbial biomass, dead microbial residues and SOM. The experimental points $(N=451)$ are based on the $2^{\text {nd }}$ database of $32{ }^{14} \mathrm{C}$ and ${ }^{13} \mathrm{C}$ labelling studies. (See references in Supplementary).

\section{Relevance of carbohydrates for soil processes}

Carbohydrates play multiple roles in soil. The key ones are: strong contribution to aggregate formation, $\mathrm{C}$ sequestration, and maintenance and stimulation of microbial activities and functions.

\subsection{Aggregate formation}

Carbohydrates are natural glue. They agglutinate mineral and organic particles well and thus promote the formation of water-stable aggregates. The capacity to affect aggregate formation depends on the composition of the carbohydrates: monomers are mainly responsible for the shortterm (hours - days) aggregate stabilization, whereas polysaccharides can glue particles together for much longer periods (Abiven et al., 2009; Jastrow, 1996). Plant litter, enriched by carbohydrates, is mainly responsible for macroaggregate formations, whereas root mucilages also contribute to the 
formation of microaggregates in the rhizosphere (Carminati and Vetterlein, 2012; Oades, 1984; Puget et al., 1999).

The carbohydrates from plant debris and root mucilages stimulate intensive microbial growth and, as a consequence, accumulation of bacterial and especially fungal mucilages in the rhizosphere and detritusphere; these mucilages serve as additional binding agents. Unlike plant carbohydrates, however, microbially derived polysaccharides bind mainly clay particles and promote the formation of microaggregates $<50 \mu \mathrm{m}$ (Puget et al., 1999). Additionally, the gluing role of glucoproteins (e.g. glomalin-related proteins) released by hyphens and spores of arbuscular mycorrhiza should be underlined (Rillig, 2004; Wright et al., 1996; Wright and Upadhyaya, 1996). Beside proteins, glucoproteins contain up to $85 \%$ of sugars, mainly glucose, which are very slowly decomposed in soil (years to decades). These glucoproteins therefore bind the mineral and organic particles to soil aggregates for long periods.

Thus, independent of origin (roots, hyphens, bacteria), carbohydrates affect aggregate formation and are the main structure-forming agents in soils. This is crucial for aeration, water permeability and holding capacity, bulk density, rooting ability, $\mathrm{C}$ sequestration, microbial activities, plant nutrition and ultimately soil fertility. As chemical agents, carbohydrates strongly affect the physical and biological properties of soils.

\subsection{SOM formation}

Plant carbohydrates are rapidly decomposed in soil and therefore, do not contribute directly to long-term $\mathrm{C}$ stabilization because they are not recalcitrant. Even considering such $\mathrm{C}$ stabilization mechanisms as encapsulation in fine aggregates and pores (Sollins et al., 1996; von Luetzow et al., 2006), the aggregates turnover from a few weeks to months (Plante and McGill, 2002) releases encapsulated residues from their composition and leads to subsequent rapid decomposition. Thus, as shown above, most of the carbohydrates within SOM are of microbial origin.

Carbohydrate $\mathrm{C}$, determined by total hydrolysis, presents on average $10 \pm 5 \%$ of SOM (Fig. 7-2) and is a mixture of plant litter, microbial residues and microbial recycling products. Nonetheless, these $10 \%$ show only the direct contribution of sugars themselves to SOM. Indirect contribution involves the substances originating from sugar $\mathrm{C}$ during microbial metabolism and stabilized later by microbial residues in SOM. Such an indirect contribution of sugar C to SOM is no doubt much higher than the direct one because sugars are used to produce nearly all microbial compounds (Gunina et al., 2014; Lengeler et al., 1999). The other main compound classes such as 
carboxylic acids, proteins and lipids are much less involved in the synthesis of cell compounds. Consequently, the total contribution of sugar C to SOM is much higher than its directly measures portion.

\subsection{Sugars: the main triggers of priming effects in rhizosphere}

About $10-30 \%$ of assimilated $\mathrm{C}$ is released by roots in the rhizosphere. About $50 \%$ of this $\mathrm{C}$ consists of sugars, and the remaining part is comprised by carboxylic acids, amino acids and phenolic compounds. The ecological relevance of the last three groups is well known: carboxylic acids decrease $\mathrm{pH}$ in the rhizosphere as well as complex and chelate metals; amino acids help mobilize $\mathrm{Fe}, \mathrm{Zn}$ and certain other micronutrients and may play a role as signaling substances; phenolic compounds are important allelopathic agents (Blum, 1998) and signaling compounds. Nonetheless, the role of sugars comprising about twice the amount of all other compounds released together in the rhizosphere) remains unknown. Clearly, sugars are not merely useless $\mathrm{C}$ losses in the rhizosphere. Such inefficient plants would not be competitive during evolution compared to others plants that avoid $\mathrm{C}$ losses. None of the identified functions, such as signaling agents or mucilage on root tips - can explain the huge amounts of sugars released by roots.

Sugars are labile organic compounds that are not absorbed by the soil mineral matrix or by SOM after release from roots. Rather, they are taken up by microorganisms within minutes and used very efficiently for both energy and cell compound production. We therefore hypothesize that the main role of sugars released by roots is to maintain interactions with rhizosphere microorganisms and to stimulate their activity. The much higher number and activity of microorganisms in the rhizosphere compared to the root-free soil accelerate SOM decomposition with mineralization of stored nutrients, mainly $\mathrm{N}, \mathrm{P}, \mathrm{S}$. If the ability of roots to solubilize nutrients by carboxylic acids is based solely on chemical processes, then the released sugars contribute to nutrient mobilization by biotic mechanisms: stimulation of microbial activity, release of exoenzymes and mineralization of SOM - the phenomena known as priming effects.

The few studies that compared the priming effects between sugars, amino acids, carboxylic acids and phenols concluded the highest stimulation by amino acids (Hamer and Marschner, 2005). Importantly, however, the amino acid concentrations in the soil and in the rhizosphere are usually one order of magnitude lower than those of sugars (Kraffczyk et al., 1984). Amino acids may also be absorbed by organic and mineral soil compounds. Consequently, sugars should play a much greater role in the unspecific stimulation of microorganisms. Therefore, we hypothesize that the 
main ecological function of the root-released sugars is to maintain high microbial activity in the rhizosphere and to trigger the priming effects. The subsequent SOM mineralization provides nutrients not only for microorganisms but also for plants, boosting their development and competitive strength compared to other plants that lack such interactions in the rhizosphere. These hypothesized functions of sugars in soil should be proven in further studies.

From various components of global change, the increasing atmospheric $\mathrm{CO}_{2}$ concentration and $\mathrm{N}$ deposition promote net primary productivity (Johnson and Pregitzer, 2007) and so, increase the carbohydrate input into soil. Additionally, elevated $\mathrm{CO}_{2}$ increases carbohydrates percentage in plant tissues (Liu et al., 2005). These increase of carbohydrate inputs as well as raising $\mathrm{C} / \mathrm{N}$ ratios of the plant litter, will decrease its decomposition rates and consequently, prolong the MRT of sugar C in soil. However, raising $\mathrm{N}$ deposition may at least partly compensate the effects of elevated $\mathrm{CO}_{2}$ on MRT of sugar $\mathrm{C}$.

\section{Conclusions and relevance}

With this review, we close several gaps in our knowledge on the content, composition and fate of carbohydrates in soil. This review compiled and analyzed two databases: the first focused on the content of total, non-cellulose, hot-water and cold-water extractable sugars in soils, as well as on the origin of sugars in soil. The second database summarized the dynamics of ${ }^{13} \mathrm{C}$ and ${ }^{14} \mathrm{C}$ sugar (mainly glucose) utilization in three pools: mineralized $\left(\mathrm{CO}_{2}\right)$, incorporated into living $\mathrm{MB}$ and stabilized within the dead microbial residues. We also estimated primary (from plants) and secondary (from microorganisms) sources of glucose $\mathrm{C}$ in soil and calculated their MRT.

Glucose dominated within the cellulose and non-cellulose sugars in soil due to its diverse origins: plant and microbial residues as well as root and microbial excretions. The ratio of hexoses to pentoses of non-cellulose sugars (applied to estimate the origin of sugars) revealed the highest values for forest soil (1.5), whereas for grasses and crops it was 0.7 and 1.0, respectively. The high ratio for forest soils was due to the presence of high amounts of hexoses in forest litter, especially in conifers, and not due to high input of microbial residues. Thus, applying the hexose to pentose ratio to identify sugar origin requires analyzing the chemical composition of plant litter.

Based on the amount of cellulose-derived glucose in soil and the assessed input of cellulose from plant biomass (using deciduous forest as an example), the MRT of cellulose was calculated as $1.4 \mathrm{y}^{-1}$. Slow decomposition of plant polysaccharides continuously delivers sugars for microorganisms to maintain their metabolism and functions. The maximal initial decomposition rate 
of glucose, taken up from soil solution, was $1.1 \% \mathrm{~min}^{-1}$, whereas the MRT of glucose in MB was $34 \mathrm{~min}^{-1}$. Such rapid decomposition of glucose together with fast uptake from soil solution must be compensated by high sugars input. Based on the sugar content in DOM and initial glucose C decomposition rate, the possible input of sugar $\mathrm{C}$ into soil solution was calculated as $5 \mathrm{Mg} \mathrm{ha}^{-1}$. The assessed input of total glucose $\mathrm{C}$ from plants (example: deciduous forest) was $1 \mathrm{Mg} \mathrm{ha}^{-1}$. Thus, only $1 / 5$ of all available sugars in soil solution is from plant biomass and 4/5 is from recycling processes.

Despite the high microbial demand for sugars, $\mathrm{C}$ from sugars is not mineralized to $\mathrm{CO}_{2}$ completely, but part of it undergoes intensive internal recycling. The calculated MRT of sugar $\mathrm{C}$ in living MB was $230 \mathrm{~d}$. This comparatively long MRT of $\mathrm{C}$ in MB can be related to i) the intensive recycling of glucose $\mathrm{C}$ within the $\mathrm{MB}$ pool and ii) its incorporation into cell polymers.

Based on the dynamics of labeled glucose $\mathrm{C}$ in SOM and in MB, we assessed the sugar C portion in microbial residues. The distribution of sugar $\mathrm{C}$ in microbial residues showed a nearly constant value (18\% of applied tracer) during a $300 \mathrm{~d}$ period. This reflects the use of sugar $\mathrm{C}$ to produce polymer cell compounds that can be stabilized within the SOM. Thus, we conclude that the contribution of sugar $C$ to the soil sugar $C$ pool is higher than the traditionally estimated $10 \pm 5 \%$ and that its importance for SOM formation is much higher than the actual amount of sugar C in the soil.

Of all processes involving sugars in soil (Fig. 7-6), microbial uptake and utilization dominate by far, strongly exceeding sorption, leaching and plant uptake. This, combined with the much higher input of carbohydrates versus other organic compounds into soil, makes sugars especially important for maintaining soil microorganisms and their activities. Further studies should focus not only on the decomposition of sugars in soil (as done in most previous experiments), but especially on their importance for microbial activities and plant-microbial interactions, where, we hypothesize, sugars play the most significant role compared to other organics released by roots.

\section{Acknowledgments}

We thank two anonymous reviewers for very helpful suggestions. The review was prepared because of its necessity, not because of funding. 


\section{References}

Abiven, S., Menasseri, S., Chenu, C., 2009. The effects of organic inputs over time on soil aggregate stability - A literature analysis. Soil Biology \& Biochemistry 41, 1-12.

Amelung, W., Cheshire, M.V., Guggenberger, G., 1996. Determination of neutral and acidic sugars in soil by capillary gas-liquid chromatography after trifluoroacetic acid hydrolysis. Soil Biology \& Biochemistry 28, 1631-1639.

Angers, D.A., Mehuys, G.R., 1990. Barley and alfalfa cropping effects on carbohydrate contents of a clay soil and its size fractions. Soil Biology \& Biochemistry 22, 285-288.

Apostel, C., Dippold, M., Kuzyakov, Y., 2015. Biochemistry of hexose and pentose transformations in soil analyzed by position-specific labeling and ${ }^{13}$ C-PLFA. Soil Biology and Biochemistry 80, 199-208.

Badalucco, L., Gelsomino, A., Dellorco, S., Grego, S., Nannipieri, P., 1992. Biochemical characterization of soil organic compounds extracted by $0.5 \mathrm{~m} \mathrm{~K}_{2} \mathrm{SO}_{4}$ before and after chloroform fumigation. Soil Biology \& Biochemistry 24, 569-578.

Ball, B.C., Cheshire, M.V., Robertson, E.A.G., Hunter, E.A., 1996. Carbohydrate composition in relation to structural stability, compactibility and plasticity of two soils in a long-term experiment. Soil \& Tillage Research 39, 143-160.

Basilevich, N.I., 1993. Biological productivity of North Eurasia systems (in russian: Биологическая продуктивность систем Северной Евразии). Moscow: Nauka, 293.

Basler, A., Dippold, M., Helfrich, M., Dyckmans, J., 2015a. Microbial carbon recycling: an underestimated process controlling soil carbon dynamics. Under review.

Basler, A., Dippold, M., Helfrich, M., Dyckmans, J., 2015b. Recycling versus Stabilisation of soil sugars- a long-term 2 laboratory incubation experiment. Biogeosciences Discussions 12, 1-29.

Basler, A., Dyckmans, J., 2013. Compound-specific $\mathrm{d}^{13} \mathrm{C}$ analysis of monosaccharides from soil extracts by high-performance liquid chromatography /isotope ratio mass spectrometry. Rapid Communications in Mass Spectrometry 27, 2546-2550.

Benzingpurdie, L., 1980. Organic matter and carbohydrate distribution in an Orthic Humic Gleysol. Soil Biology \& Biochemistry 12, 567-571.

Blagodatskaya, E., Khomyakov, N., Myachina, O., I., B., S., B., Kuzyakov, Y., 2014. Microbial interactions affect sources of priming induced by cellulose. Soil Biology \& Biochemistry 74, 39-49.

Blagodatskaya, E., Kuzyakov, Y., 2013. Active microorganisms in soil: critical review of estimation criteria and approaches. Soil Biology \& Biochemistry 67, 192-211.

Blum, U., 1998. Effects of Microbial Utilization of Phenolic Acids and their Phenolic Acid Breakdown Products on Allelopathic Interactions. Journal of Chemical Ecology 24, 685-708.

Bongiovanni, M.D., Lobartini, J.C., 2006. Particulate organic matter, carbohydrate, humic acid contents in soil macro- and microaggregates as affected by cultivation. Geoderma 136, 660665.

Carminati, A., Vetterlein, D., 2012. Plasticity of rhizosphere hydraulic properties as a key for efficient utilization of scarce resources. Annals of Botany 12, DOI: 10.1093/aob/mcs1262.

Cheshire, M.V., 1979. Nature ans origin of carbohydrates in soil. Academic Press inc. (London) LTD.

Cheshire, M.V., Christensen, B.T., Sorensen, L.H., 1990. Labelled and native sugars in particle-size fractions from soils incubated with 14C straw for 6 to 18 years. Journal of Soil Science 41, 29-39. 
Cheshire, M.V., Mundie, C.M., 1966. The hydrolytic extraction of carbohydrates from soil by sulphuric acid Jounal of Soil Science 17, 372-381.

Cheshire, M.V., Mundie, C.M., Shepherd, H., 1971. The origin of the pentose fraction of soil polysaccharide. Jounal of Soil Science 22.

Coody, P.N., Sommers, L.E., Nelson, D.W., 1986. kinetics of glucose uptake by soil microorganisms. Soil Biology \& Biochemistry 18, 283-289.

Dalal, R.C., Henry, R.J., 1988. Cultivation effects on carbohydrate contents of soil and soil fractions. Soil Science Society of America Journal 52, 1361-1365.

Derrien, D., Marol, C., Balesdent, J., 2004. The dynamics of neutral sugars in the rhizosphere of wheat. An approach by C-13 pulse-labelling and GC/C/IRMS. Plant and Soil 267, 243-253.

Derrien, D., Marol, C., Balesdent, J., 2007. Microbial biosyntheses of individual neutral sugars among sets of substrates and soils. Geoderma 139, 190-198.

Dormaar, J.F., 1994. Monosaccharide status of pre- Mazama Ahb horizons in Alberta,Canada. Canadian Journal of Soil Science 74, 55-58.

Doutre, D.A., Hay, G.W., Hood, A., Vanloon, G.W., 1978. Spectrophotometric methods to determine carbohydrates in soil. Soil Biology \& Biochemistry 10, 457-462.

Fioretto, A., C. , Nardo, D., Papa, S., Fuggi, A., 2005. Lignin and cellulose degradation and nitrogen dynamics during decomposition of three leaf litter species in a Mediterranean ecosystem. Soil Biology \& Biochemistry 37, 1083-1091.

Fischer, H., Ingwersen, J., Kuzyakov, Y., 2010. Microbial uptake of low-molecular-weight organic substances out-competes sorption in soil. European Journal of Soil Science 61, 504-513.

Fischer, H., Meyer, A., Fischer, K., Kuzyakov, Y., 2007. Carbohydrate and amino acid composition of dissolved organic matter leached from soil. Soil Biology \& Biochemistry 39, 2926-2935.

Folsom, B.U., Wagner, G.H., Scrivner, C.L., 1974. Comparison of soil carbohydrate in several prairie and forest soils by gas-liquid chromatography. Proc. Soil. Sci. Soc. Am 38, 305-309.

Grandy, A.S., Erich, M.S., Porter, G.A., 2000. Suitability of the anthrone-sulfuric acid reagent for determining water soluble carbohydrates in soil water extracts. Soil Biology \& Biochemistry 32, 725-727.

Grayston, S.J., Campbell, C.D., 1996. Functional biodiversity of microbial communities in the rhizospheres of hybrid larch (Larix eurolepis) and Sitka spruce (Picea sitchensis). Tree Physiology 16, 1031-1038.

Guggenberger, G., Thomas, R.J., Zech, W., 1996. Soil organic matterwithin earthworm casts of an anecic-endogeic tropical pasturecommunity. Appl Soil Ecol 3, 263-274.

Gunina, A., Dippold, M., Glaser, B., Kuzyakov, Y., 2014. Fate of low molecular weight organic substances in an arable soil: From microbial uptake to utilisation and stabilisation. Soil Biology \& Biochemistry 77, 304-313.

Hamer, U., Marschner, B., 2005. Priming effects in different soil types induced by fructose, alanine, oxalic acid and catechol additions. Soil Biology \& Biochemistry 37, 445-454.

Haynes, R.J., Francis, G.S., 1993. Changes in microbial biomass C, soil carbohydrate composition and aggregate stability induced by growth of selected crop and forage species under field conditions. Journal of Soil Science 44, 665-675.

Helal, H.M., Sauerbeck, D., 1989. Carbon turnover in the rhizosphere. Zeitschrift Fur Pflanzenernahrung Und Bodenkunde 152, 211-216.

Hishi, T., Hirobe, M., Tateno, R., Takeda, H., 2004. Spatial and temporal patterns of waterextractable organic carbon (WEOC) of surface mineral soil in a cool temperate forest ecosystem. Soil Biology \& Biochemistry 36, 1731-1737. 
Hobbie, J.E., Hobbie, E.A., 2013 Microbes in nature are limited by carbon and energy: the starvingsurvival lifestyle in soil and consequences for estimating microbial rates. Frontiers in Microbiology 4, 324.

Hofman, J., Dusek, L., 2003. Biochemical analysis of soil organic matter and microbial biomass composition - a pilot study. European Journal of Soil Biology 39, 217-224.

Hu, S., Coleman, D.C., Hendrix, P.F., Beare, M.H., 1995. Biotic manipulation effects on soil carbohydrates and microbial biomass in a cultivated soil. Soil Biology \& Biochemistry 27, 1127-1135.

Hutsch, B.W., Augustin, J., Merbach, W., 2002. Plant rhizodeposition - an important source for carbon turnover in soils. Journal of Plant Nutrition and Soil Science-Zeitschrift Fur Pflanzenernahrung Und Bodenkunde 165, 397-407.

Jastrow, J.D., 1996. Soil aggregate formation and the accrual of particulate and mineral-associated organic matter. Soil Biology \& Biochemistry 28, 665-676.

Joergensen, R.G., Mueller, T., Wolters, V., 1996. Total carbohydrates of the soil microbial biomass in 0.5 M K2SO4 soil extracts. Soil Biology \& Biochemistry 28, 1147-1153.

Johnson, R.M., Pregitzer, K.S., 2007. Concentration of sugars, phenolic acids, and amino acids in forest soils exposed to elevated atmospheric CO2 and O-3. Soil Biology \& Biochemistry 39, 3159-3166.

Jones, D.L., 1998. Organic acids in the rhizosphere - a critical review. Plant and Soil 205, 25-44.

Jones, D.L., Darrah, P.R., 1992. Resorption of organic-components by roots of Zea mays L. and its consequences in the rhizosphere. 1. Resorption of ${ }^{14} \mathrm{C}$ labeled glucose, mannose and citricacid. Plant and Soil 143, 259-266.

Jones, D.L., Kemmitt, S.J., Wright, D., Cuttle, S.P., Bol, R., Edwards, A.C., 2005. Rapid intrinsic rates of amino acid biodegradation in soils are unaffected by agricultural management strategy. Soil Biology \& Biochemistry 37, 1267-1275.

Jones, D.L., Murphy, D.V., 2007. Microbial response time to sugar and amino acid additions to soil. Soil Biology \& Biochemistry 39, 2178-2182.

Kaiser, K., Kalbitz, K., 2012. Cycling downwards - dissolved organic matter in soils. Soil Biology \& Biochemistry 52, 29-32.

Kogel-Knabner, I., 2002. The macromolecular organic composition of plant and microbial residues as inputs to soil organic matter. Soil Biology \& Biochemistry 34, 139-162.

Kraffczyk, I., Trolldenier, G., Beringer, H., 1984. Soluble root exudates of maize: influence of potassium supply and rhizosphere microorganisms. Soil Biology \& Biochemistry 16, 315-322.

Kuzyakov, Y., 2010. Priming effects: interactions between living and dead organic matter. Soil Biology and Biochemistry 42, 1363-1371.

Kuzyakov, Y., 2011. How to link soil C pools with $\mathrm{CO}_{2}$ fluxes? Biogeosciences 8, 1523-1537.

Kuzyakov, Y., Domanski, G., 2000. Carbon input by plants into the soil. Review. Plant Nutrition and Soil Science 163, 421-431.

Kuzyakov, Y., Jones, D.L., 2006a. Glucose uptake by maize roots and its transformation in the rhizosphere. Soil Biology \& Biochemistry 38, 851-860.

Kuzyakov, Y., Jones, D.L., 2006b. Glucose uptake by maize roots and its transformation in the rhizosphere. Soil Biology \& Biochemistry 38, 851-860.

Lengeler, J.W., Drews, G., Schlegel, H.G., 1999. Biology of the prokaryotes. Georg Thieme Verlag, 955.

Lettau, T., Kuzyakov, Y., 1999. Verwertung organischer Substanzen durch mikrobielle Bodenbiomasse als eine Funktion chemisch-thermodynamischer Parameter. Zeitschrift Fur Pflanzenernahrung Und Bodenkunde 162, 171-177. 
Liu, L., King, J.S., Giardina, C.P., 2005. Effects of elevated atmospheric $\mathrm{CO}_{2}$ and tropospheric $\mathrm{O}_{3}$ on leaf litter production and chemistry in trembling aspen and paper birch ecosystems. Tree Physiology 15, 1511-1522.

Maire, V., Alvarez, G., Colombet, J., Comby, A., Despinasse, R., Dubreucq, E., Joly, M., Lehours, A.C., Perrier, V., Shahzad, T., Fontaine, S., 2013. An unknown oxidative metabolism substantially contributes to soil $\mathrm{CO}_{2}$ emissions. Biogeosciences 10, 1155-1167.

Martens, D.A., Frankenberger, W.T., 1990. Quantification of soil saccharides by spectrophotometric methods. Soil Biology \& Biochemistry 22, 1173-1175.

Martens, D.A., Loeffelmann, K.L., 2002. Improved accounting of carbohydrate carbon from plants and soils. Soil Biology \& Biochemistry 34, 1393-1399.

Martin, J.P., Haider, K., Farmer, W.J., Fustecma.E, 1974. Decomposition and distribution of residual activity of some 14C-microbial polysaccharides and cells, glucose, cellulose and wheat straw in soil. Soil Biology \& Biochemistry 6, 221-230.

Meharg, A.A., 1994. A critical review of labelling techniques used to quantify rhizosphere carbonflow. Plant and Soil 166, 55-62.

Moore, J.C., McCann, K., de Ruiter, P.C., 2005. Modeling trophic pathways, nutrient cycling, and dynamic stability in soils. Pedobiologia 49, 499-510.

Murata, T., Tanaka, H., Yasue, S., Hamada, R., Sakagami, K., Kurokawa, Y., 1999. Seasonal variations in soil microbial biomass content and soil neutral sugar composition in grassland in the Japanese Temperate Zone. Applied Soil Ecology 11, 253-259.

Oades, J.M., 1984. Soil organic matter and structural stability: Mechanisms and implications for management. Plant and Soil 76, 319-337.

Oades, J.M., Wagner, G.H., 1970. Incorporation of ${ }^{14} \mathrm{C}$ into sugars in a soil incubated with ${ }^{14} \mathrm{C}$ glucose. Geoderma 4, 417-423.

Olsson, R., Giesler, R., Persson, P., 2011. Adsorption mechanisms of glucose in aqueous goethite suspensions. Journal of Colloid and Interface Science 35, 263-268.

Pan, X., Song, W., Zhang, D., 2010. Earthworms (Eisenia foetida , Savigny) mucus as complexing ligand for imidacloprid. Biology and Fertility of Soils 46, 845-850.

Parton, W.J., Schimel, D.S., Cole, C.V., Ojima, D.S., 1987. Analysis of factors controlling soil organic matter levels in Great Plains grasslands. Soil Sci. Soc. Am. J. 51, 1173-1179.

Payne, W.J., 1970. Energy yields and growth of heterotrophs. Annual Review of Microbiology 24, 17-52.

Plante, A.F., McGill, W.B., 2002. Intraseasonal Soil Macroaggregate Dynamics in Two Contrasting Field Soils Using Labeled Tracer Spheres. Soil Science Society of America Journal 66, 12851295.

Puget, P., Angers, D.A., Chenu, C., 1999. Nature of carbohydrates associated with water-stable aggregates of two cultivated soils. Soil Biology \& Biochemistry 31, 55-63.

Rillig, M.C., 2004. Arbuscular mycorrhizae and terrestrial ecosystem processes. Ecology Letters 7, 740-754.

Rodriguez-Sanchez, S., Hernandez-Hernandez, O., Ruiz-Matute, A.I., Sanz, M.L., 2011. A derivatization procedure for the simultaneous analysis of iminosugars and other low molecular weight carbohydrates by GC-MS in mulberry (Morus sp.). Food Chemistry 126, 353-359.

Rousk, J., Baath, E., 2007. Fungal biomass production and turnover in soil estimated using the acetate-in-ergosterol technique. Soil Biology \& Biochemistry 39, 2173-2177.

Salamanca, E.F., Kaneko, N., Katagiri, S., 2003. Rainfall manipulation effects on litter decomposition and the microbial biomass of the forest floor. Applied Soil Ecology 22, 271281. 
Sariyildiz, T., Anderson, J.M., 2003. Interactions between litter quality, decomposition and soil fertility: a laboratory study. Soil Biology \& Biochemistry 35, 391-399.

Sariyildiz, T., Anderson, J.M., 2005. Variation in the chemical composition of green leaves and leaf litters from three deciduous tree species growing on different soil types. Forest Ecology and Management 210, 303-319.

Schaedel, C., Boechl, A., Richter, A., Hoch, G., 2010. Quantification and monosaccharide composition of hemicelluloses from different plant functional types. Plant Physiology and Biochemistry 48, 1-8.

Sinsabaugh, R.L., Manzoni, S., Moorhead, D.L., Richter, A., 2013. Carbon use efficiency of microbial communities: stoichiometry, methodology and modelling. Ecology Letters 16, 930939.

Six, J., Elliott, E.T., Paustian, K., 1999. Aggregate and soil organic matter dynamics under conventional and no-tillage systems. Soil Science Society of America Journal 63, 1350-1358.

Sollins, P., Homann, P., Caldwell, B.A., 1996. Stabilization and destabilization of soil organic matter: Mechanisms and controls. Geoderma 74, 65-105.

Spielvogel, S., Prietzel, J., Koegel-Knabner, I., 2007. Changes of lignin phenols and neutral sugars in different soil types of a high-elevation forest ecosystem 25 years after forest dieback. Soil Biology \& Biochemistry 39, 655-668.

Tanaka, H., Hamada, R., Kondoh, A., Sakagami, K., 1990. Determination of component sugars in soil organic matter by HPLC. Zentralblatt Fur Mikrobiologie 145, 621-628.

Tian, L., Dell, E., Shi, W., 2010. Chemical composition of dissolved organic matter in agroecosystems: Correlations with soil enzyme activity and carbon and nitrogen mineralization. Applied Soil Ecology 46, 426-435.

Uzaki, M., Ishiwatari, R., 1983. Determination of cellulose and non-cellulose carbohydrates in recent sediments by gas chromatography. Chromatography 260, 487-492.

von Luetzow, M., Koegel-Knabner, I., Ekschmitt, K., Matzner, E., Guggenberger, G., Marschner, B., Flessa, H., 2006. Stabilization of organic matter in temperate soils: mechanisms and their relevance under different soil conditions - a review. European Journal of Soil Science 57, 426445.

Warembourg, F.R., Estelrich, H.D., 2000. Towards a better understanding of carbon flow in the rhizosphere: a time-dependent approach using carbon-14. Biol. Fert. Soils 30, 528-534.

Wright, S.F., Franke-Snyder, M., Morton, J.B., Upadhyaya, A., 1996. Time course study and partial characterization of a protein on hyphae of arbuscular mycorrhizal fungi during active colonization of roots. Plant and Soil 181, 193-203.

Wright, S.F., Upadhyaya, A., 1996. Extraction of an abundant and unusual protein from soil and comparison with hyphal protein of arbuscular mycorrhizal fungi. Soil Science 161, 575-586.

Zech, M., Werner, R.A., Juchelka, D., Kalbitz, K., Buggle, B., Glaser, B., 2012. Absence of oxygen isotope fractionation/exchange of (hemi-) cellulose derived sugars during litter decomposition. Organic Geochemistry 42, 1470-1475.

Zhang, C.-B., Chen, L.-H., Jiang, J., 2014. Why fine tree roots are stronger than thicker roots: The role of cellulose and lignin in relation to slope stability. Geomorphology 206, 196-202.

Zhang, S.J., Hu, F., Li, H.X., Li, X.Q., 2009. Influence of earthworm mucus and amino acids on tomato seedling growth and cadmium accumulation. Environmental Pollution 157, 27372742.

Zhang, W., He, H., Zhang, X., 2007. Determination of neutral sugars in soil by capillary gas chromatography after derivatization to aldononitrile acetates. Soil Biology \& Biochemistry 39, 2665-2669. 


\title{
Chapter 8 Article VI Microbial uptake and utilization of low molecular weight organic substrates in soil depend on carbon oxidation state
}

\author{
Anna Gunina $^{\mathrm{a}, \mathrm{b}}$, Andrew R. Smith ${ }^{\mathrm{a}}$, Yakov Kuzyakov ${ }^{\mathrm{b}, \mathrm{c}}$, Davey L. Jones ${ }^{\mathrm{a}}$ \\ ${ }^{a}$ School of Environment, Natural Resources and Geography, Bangor University, Bangor, Gwynedd, \\ LL57 2UW, UK \\ ${ }^{\mathrm{b}}$ Department of Agricultural Soil Science, Georg-August University of Göttingen, Göttingen, 37077, \\ Germany \\ ${ }^{\mathrm{c}}$ Department of Soil Science of Temperate Ecosystems, Georg-August University of Göttingen, \\ Göttingen, 37077, Germany
}

Biogeochemistry, 2017, Volume 133, Issue 1, pp 89-100.

Author contributions: Anna Gunina prepared the manuscript.

All other authors contributed to the final version of manuscript

Key words: carbon use efficiency, CUE, decomposition kinetics, dissolved organic nitrogen, organic acids. 


\section{Abstract}

The fate of low molecular weight organic substances (LMWOS) in soil is regulated by microbial uptake. However, $\mathrm{C}$ oxidation state, the number of $\mathrm{C}$ atoms and $-\mathrm{COOH}$ groups in the LMWOS can affect their microbial utilization. Thus, the aim of this study was to reveal the effects of substance chemical properties on initial uptake and utilization of sugars, carboxylic and amino acids by microorganisms.

Soil solution, spiked with ${ }^{14} \mathrm{C}$-labelled glucose, fructose, malate, succinate, formate, alanine or glycine, was added to the soil and ${ }^{14} \mathrm{C}$ was traced in the soil solution, $\mathrm{CO}_{2}$, cytosol, and soil organic carbon (SOC) over 24 hours.

The half-life time of all LMWOS in the soil solution varied between $0.6 \mathrm{~min}$ (formic acid) and 5.0 min (sugars), indicating its dependence on $\mathrm{C}$ oxidation state of the substances. The half-life time of ${ }^{14} \mathrm{C}$ in the fast mineralized pool in microorganisms, ranged between 30 (malic acid) and 80 (glycine) min and was independent on either $\mathrm{C}$ oxidation state, the number of $\mathrm{C}$ atoms, or number of $-\mathrm{COOH}$ groups. This suggests that intercellular metabolic pathways are more important for LMWOS transformation in soil than their basic chemical properties. The portion of mineralized LMWOS increased with their C oxidation state (20\% for sugars $v s$. 90\% for formic acid) corresponding to the decrease of $\mathrm{C}$ incorporated into the cytosol and SOC pools.

Concluding, the physicochemical properties of the common LMWOS allow predicting their microbial uptake from soil solution and subsequent partitioning of $\mathrm{C}$ within microbial biomass. 


\section{Introduction}

Low molecular weight organic substances (LMWOS) in soil originate from a wide range of sources, including root and microbial exudation, animal wastes, canopy throughfall, and the decomposition of plant and microbial necromass. Although LMWOS typically represent a small proportion of the total dissolved organic carbon (DOC) pool in soil, they play a critical role in many soil processes, including complexation of metal ions which increases their mobilization (e.g. carboxylic acids), as an important $\mathrm{N}$ source (e.g. amino acids) for plants and microorganisms, and as a source of $\mathrm{C}$ and energy for microorganisms (e.g. sugars) (Blagodatskaya and Kuzyakov, 2013; Grayston et al., 1997; Hill et al., 2012). From a global perspective, LMWOS contribute significantly to total soil $\mathrm{CO}_{2}$ flux (up to 30\%) (van Hees et al., 2005) and thus represent an important parameter for modeling of soil organic carbon (SOC) dynamics.

Although LMWOS may be leached, become sorbed to the solid phase, abiotically mineralized or used by plants, their uptake by the microbial communities dominates their longevity in soil solution and represents the first step of their utilization (Glanville et al., 2016). The uptake of LMWOS from solution depends on their properties, namely broad substrate class (e.g. sugars, phenolics etc), which determines its subsequent use within cell metabolism (Gunina et al., 2014; Apostel et al., 2013), and concentration, which determines the transport systems used by microorganisms for taking up LMWOS (Hill et al., 2008). In addition, for amino acids it has been shown that substances with low $\mathrm{C}$ oxidation states (e.g. lysine) are taken up by microorganisms slower than ones having higher $\mathrm{C}$ oxidation states (e.g. glycine and glutamate) (Jones and Hodge, 1999), while the fate of carboxylic acids in soil is dependent on their solubility and association with the soil's solid phase (Gunina et al., 2014). Thus, even if the general substance class plays a major role in the fate of LMWOS in soils, the physico-chemical properties of the individual compound are also highly important.

The second step of LMWOS utilization by microorganisms is their incorporation into metabolic cycles and subsequent mineralization to $\mathrm{CO}_{2}$ or immobilization within cellular components (Apostel et al., 2013). It has also been shown that intercellular metabolism affects the fate of amino and carboxylic acid derived-C in soils (Gunina et al., 2014), as each compound class enters distinct metabolic cycles within the cell. The proportion of each mineralized LMWOS is also linked to the $\mathrm{C}$ oxidation state of the substrate. Carboxyl groups $(-\mathrm{COOH})(\mathrm{C}$ oxidation state $=$ $+3.0)$ are mineralized to $\mathrm{CO}_{2}$ at a higher amount than methyl groups $\left(-\mathrm{CH}_{3}\right)(\mathrm{C}$ oxidation state $=-$ 3.0) (Fischer and Kuzyakov, 2010). So, the presence of a high number of reduced $C$ atoms in 
LMWOS molecules can lead to low mineralization and high LMWOS-C incorporation into structural elements of the cell. At the same time, a higher proportion of mineralized $\mathrm{C}$ should be observed for substances with high number of oxidized $\mathrm{C}$ atoms (e.g. substrates rich in $-\mathrm{COOH}$ groups). Additionally, the standard enthalpy of combustion of organic compounds seems to be dependent on substance $\mathrm{C}$ oxidation state: for substances with "0" C oxidation state (e.g. glucose, alanine) the values of standard enthalpy of combustion are in the range 1600-2800 kJ/mol, whereas for oxidized substances (C oxidation state +1 or +2 ) the values are lower: $280-1300 \mathrm{~kJ} / \mathrm{mol}$. Thus, substance physico-chemical properties can directly impact the utilization processes of LMWOS within the microorganisms. In contrast, further fate of C contained within LMWOS may be closely related to cell metabolite turnover, where this $\mathrm{C}$ was incorporated during intercellular metabolisation (Glanville et al., 2016).

The aim of the study was to estimate the initial utilization (within $24 \mathrm{~h}$ of LMWOS application) of three main LMWOS classes (sugars, carboxylic and amino acids) and to reveal the effect of substance properties on their fate within soil. We hypothesized that: i) LMWOS half-life times in soil solution will depend on substance properties, namely $\mathrm{C}$ oxidation state, number of $\mathrm{COOH}$ groups and size of the molecules, ii) the half-life of LMWOS-C in microbial biomass pool will depend on the properties of LMWOS and the pathway taken when entering into intercellular metabolic cycles, and iii) substances with a high $\mathrm{C}$ oxidation state will be mineralized to a larger extent than substances with a low $\mathrm{C}$ oxidation state.

\section{Materials and methods}

\subsection{Site description and soil sampling}

Soil was collected from the BangorDIVERSE long-term forest diversity experiment, located in Abergwyngregyn, North Wales, UK (5314'16" N, 4¹'1" W) (Smith et al., 2013; Ahmed et al., 2016). Within this experiment, soil was collected from the replicated Silver birch (Betula pendula Roth.) plots. The soil is classified as a fine loamy textured Dystric Fluvic Cambisol (WRB, 2006) and has a mixed glacial till parent material. The site has a mean annual soil temperature of $10.6{ }^{\circ} \mathrm{C}$ and an annual rainfall of ca. $950 \mathrm{~mm}$. The basic properties of the soil are presented in Table 8-1 and in Ahmed et al. (2016). At each sampling site, surface litter (ca. 1-2 cm) was removed and the top $10 \mathrm{~cm}$ of the mineral soil (excluding litter layer) was collected from four independent locations within each of four replicate plots and combined to make a composite soil sample. 
Soil samples were stored in gas-permeable plastic bags at $5{ }^{\circ} \mathrm{C}$ until extraction of soil solution, which was conducted within $24 \mathrm{~h}$ of sample collection. Substrate uptake and mineralization experiments were conducted within one week of soil sample collection.

Table 8-1. Selected soil properties.

\begin{tabular}{llllllll}
\hline Sand & Silt & Clay & Moisture content $\mathrm{pH}$ & Total C & Total N C-to-N ratio \\
$\left(\mathrm{g} \mathrm{kg}^{-1}\right)$ & $\left(\mathrm{g} \mathrm{kg}^{-1}\right)$ & $\left(\mathrm{g} \mathrm{kg}^{-1}\right)$ & $(\%)$ & $\left(\mathrm{g} \mathrm{kg}^{-1}\right)$ & $\left(\mathrm{g} \mathrm{kg}^{-1}\right)$ & \\
& & & & & & & \\
\hline $48.2 \pm 1.3$ & $33.6 \pm 0.9$ & $18.2 \pm 2.1$ & $32.9 \pm 0.5$ & $5.40 \pm 0.03$ & $32.2 \pm 1.2$ & $3.2 \pm 0.3$ & $10.6 \pm 0.3$
\end{tabular}

Soil texture was determined by laser diffraction. $\mathrm{pH}$ was measured in 1:2.5 (w/v) soil:distilled water extracts. Total $\mathrm{C}$ and $\mathrm{N}$ were determined by dry combustion. Values represent the means $\pm \operatorname{SE}(n=4)$.

\subsection{Extraction of soil solution}

Soil solution was obtained by centrifugation following the technique of Glanville et al. (2012). Briefly, $100 \mathrm{~g}$ of fresh soil was placed into a polypropylene centrifuge tube with a perforated bottom and covered by a fine mesh (pore size $50 \mu \mathrm{m}$ ). This was attached to a base unit which collects soil solution during centrifugation. This construction was centrifuged at $3500 \mathrm{~g}$ for $15 \mathrm{~min}$. The extracted soil solution was subsequently passed through a $0.2 \mu \mathrm{m}$ cellulose acetate filter to remove microbial contaminants and stored at $-20^{\circ} \mathrm{C}$ prior to use in subsequent experiments.

\subsection{LMWOS uptake from soil solution}

The uptake of LMWOS by the soil microbial community was measured over $24 \mathrm{~h}$ for sugars (glucose and fructose), carboxylic acids (malic, succinic and formic acids) and amino acids (alanine and glycine). These substrates were chosen as they are either commonly found in root exudates/lysates or they represents the breakdown products arising from the main organic polymers entering soil (i.e. cellulose/protein). The C oxidation state of each LMWOS was calculated as sum of all $\mathrm{C}$ oxidation states divided by the amount of $\mathrm{C}$ atoms in the substance (Table 8-2).

The ${ }^{14} \mathrm{C}$ radiolabeled substances $(<10 \mathrm{nM})$ were added separately to the extracted soil solution (see section 2.2) to obtain a total ${ }^{14} \mathrm{C}$ specific activity of $0.83 \mathrm{kBq} \mathrm{ml}^{-1}$ for each compound. No additional non-labeled substances were added so that we did not want to change the intrinsic concentrations of the compounds naturally present in soil solution. All LMWOS were uniformly labeled and ${ }^{14} \mathrm{C}$ specific activities of the each initial substances were: ${ }^{14} \mathrm{C}$-glucose $7.4 \mathrm{MBq} \mathrm{ml}^{-1}$, 
${ }^{14} \mathrm{C}$-fructose $37 \mathrm{MBq} \mathrm{ml}{ }^{-1}$, ${ }^{14} \mathrm{C}$-malic acid $3.7 \mathrm{MBq} \mathrm{ml}^{-1},{ }^{14} \mathrm{C}$-succinic acid $3.7 \mathrm{MBq} \mathrm{ml}^{-1},{ }^{14} \mathrm{C}$ formic acid $35.6 \mathrm{MBq} \mathrm{ml}^{-1},{ }^{14} \mathrm{C}$-alanine $3.7 \mathrm{MBq} \mathrm{ml}^{-1},{ }^{14} \mathrm{C}_{\text {-glycine }} 1.8 \mathrm{MBq} \mathrm{ml}^{-1}$.

To measure the depletion of the LMWOS from soil solution, fresh field-moist soil $(1.2 \mathrm{~g})$ was placed into a $1.5 \mathrm{~cm}^{3}$ polypropylene microcentrifuge tube and $0.3 \mathrm{ml}$ of ${ }^{14} \mathrm{C}$-labelled soil solution was added to the soil surface. The solution immediately infiltrated into the soil. The microcentrifuge tubes were perforated at the bottom and the holes were covered with a small piece of Whatman GF/A glass fiber filter paper (pore size $1.6 \mu \mathrm{m}$ ). These soil-filled microcentrifuge tubes was then placed on top of another empty microcentrifuge tube and the dual-tube array was centrifuged $(14,000 \mathrm{~g}, 1 \mathrm{~min})$. The soil solution from the upper tube passed to the lower tube where it was recovered for analysis. Soil solution was obtained 1, 4, 8, 10, 20, 30, 60, 240, 960 and 1440

min after addition of the ${ }^{14} \mathrm{C}$-labelled solution to the surface of the soil in the upper microcentrifuge tube. ${ }^{14} \mathrm{C}$ activity of the recovered soil solution was measured by liquid scintillation counting (Wallac 1409 scintillation counter, Wallac EG\&G Ltd, Milton Keynes, UK) using Wallac Optiphase 3 scintillation cocktail (Wallac EG\&G Ltd, Milton Keynes, UK). This procedure was also done with sterile soil (autoclaved, $121^{\circ} \mathrm{C}, 30 \mathrm{~min}$ ) to determine the importance of abiotic losses of LMWOS from soil solution (i.e. sorption to the solid phase) in the absence of the microbial activity (Hill et al., 2008). Each component of the experiment was replicated four times. The uptake rate of ${ }^{14} \mathrm{C}$-labelled LMWOS from soil solution was calculated as follows:

$$
R=a_{1}+a_{2} \exp ^{-k t}
$$

where $R$ is the percent of applied ${ }^{14} \mathrm{C}$ remaining in soil solution, $a_{1}$ is an asymptote to which ${ }^{14} \mathrm{C}$ activity fells in single exponential curves, $a_{2}$ is an estimated pool size for uptake, $t$ is time and $k$ is an uptake rate constant. The half-life times of LMWOS in soil solution $\left(T_{1 / 2}\right.$ solution) were calculated as $\ln (2) / k$. As the main portion $(>80 \%)$ of the applied tracer was taken up from soil solution within $60 \mathrm{~min}$, only this period of time is presented, whereas the single first order kinetic equation was fitted to all the data collected over the experimental period ( $24 \mathrm{~h})$.

\subsection{LMWOS mineralization in soil}

To estimate the mineralization rate of each LMWOS, a similar procedure to that described above was employed except that we measured the rate of ${ }^{14} \mathrm{CO}_{2}$ evolution from the soil. Briefly, fresh soil $(1.2 \mathrm{~g})$ was placed into a $1.5 \mathrm{ml}$ microcentrifuge tube and $0.3 \mathrm{ml}$ of each ${ }^{14} \mathrm{C}$-labeled solution added (according to procedure described above). The microcentrifuge tubes were placed into a larger $50 \mathrm{ml}$ polypropylene container and a $1 \mathrm{M} \mathrm{NaOH}$ trap $(1 \mathrm{ml})$ added to capture evolved 
$\mathrm{CO}_{2}$ in the closed system. The $\mathrm{NaOH}$ traps were changed at $1.5,3.5,5.5,8.5,13,22,24,25.5$ and $27.5 \mathrm{~h}$ after LMWOS addition. ${ }^{14} \mathrm{C}$ activity of the $\mathrm{NaOH}$ solutions was measured by liquid scintillation counting as described above. To describe mineralization rate of each LMWOS, a double first order kinetic equation was applied to the portion of ${ }^{14} \mathrm{C}$ remaining in the soil $\left({ }^{14} \mathrm{C}_{\text {SOC }}\right)$, (calculated as $100-{ }^{14} C_{\mathrm{CO}_{2}}(\%)$ ):

$$
{ }^{14} C_{S O C}=a \cdot \exp ^{-k_{a} t}+b \cdot \exp { }^{-k_{b} t},
$$

where $a$ and $b$ are pool sizes for the fast and slow mineralization phases, $t$ is time and $k_{\mathrm{a}}$ and $k_{\mathrm{b}}$ are the rate constants for the fast and slow mineralization phases (Glanville et al., 2016). The $T_{1 / 2}$ for LMWOS-C of the fast and slow phases of $\mathrm{C}$ mineralization within the microbial community were calculated as $\ln (2) / k_{\mathrm{a}}$ or $\ln (2) / k_{\mathrm{b}}$ and will subsequently be referred to as $T_{1 / 2 \text {-fast }}$ and $T_{1 / 2 \text {-slow }}$ respectively.

At the end of the experiment $(27.5 \mathrm{~h}),{ }^{14} \mathrm{C}$ activity was measured in the microbial cytosol pool using the chloroform fumigation-extraction procedure of $\mathrm{Wu}$ et al. (1990). As no extraction efficiency correction factor was applied to the extracted dissolved organic $\mathrm{C}$ pool after fumigation (Glanville et al., 2016), this pool was referred to "cytosol" rather than microbial biomass. The amount of ${ }^{14} \mathrm{C}$ remaining in the bulk soil at the end was also measured by combusting the soil at 800 ${ }^{\circ} \mathrm{C}$ in a OX400 biological oxidiser (R.J. Harvey Instrument Corp., USA) and ${ }^{14} \mathrm{CO}_{2}$ measured by scintillation counting after capture in Oxosol scintillant (National Diagnostics, Atlanta, GA, USA). To obtain ${ }^{14} \mathrm{C}$ in $\mathrm{SOC}$ pool (further referred to as ${ }^{14} \mathrm{C}-\mathrm{SOC}$ ) the ${ }^{14} \mathrm{C}$ portions in $\mathrm{CO}_{2}$ and cytosol pools were subtracted from ${ }^{14} \mathrm{C}$ in bulk soil, and present the pool containing non-extractable microbial biomass and microbial metabolites. Tracer incorporation into cytosol and SOC pools was presented as a percent of the total applied ${ }^{14} \mathrm{C}$.

Based on the calculated ${ }^{14} \mathrm{C}$ incorporation into $\mathrm{CO}_{2}$ and microbial cytosol pools (for the last measurement point $-27.5 \mathrm{~h}$ ), the anabolism to catabolism ratio was calculated as:

$$
\frac{\text { anabolism }}{\text { catabolism }}=\frac{{ }^{14} C_{\text {cytosol }}}{{ }^{14} C_{\mathrm{CO}_{2}}} \text {, }
$$

which shows the proportion of ${ }^{14} \mathrm{C}$ used for energy production relative to that incorporated into cell components. 


\subsection{Statistics}

Data on ${ }^{14} \mathrm{C}$ in $\mathrm{CO}_{2}$, cytosol and $\mathrm{SOC}$ as well as pool sizes, rate constants and $\mathrm{T}_{1 / 2}$ were subjected to ANOVA and significant differences between the various LMWOS were tested with LSD post hoc test with $P<0.05$. Exponential equations were fitted to the experimental results using a least squares iteration routine in Statistica 10.0 (Dell Statistica Inc., Tulsa, OK). The simple regression analysis was performed in Statistica 10.0 (Dell Statistica Inc., Tulsa, OK) with data on C oxidation state, number of $\mathrm{C}$ atoms, number of $\mathrm{COOH}$ groups vs. LMWOS $T_{1 / 2 \text { solution }}, T_{1 / 2 \text {-fast }}, T_{1 / 2 \text {-slow }}$, portion of ${ }^{14} \mathrm{C}$ in $\mathrm{SOC}$, cytosol and $\mathrm{CO}_{2}$ pools.

\section{Results}

\subsection{Uptake of LMWOS from soil solution}

The three classes of LMWOS showed a similar uptake pattern from soil solution based on the ${ }^{14} \mathrm{C}$ depletion from the DOC pool (Fig. 8-1). Calculated LMWOS-C $T_{1 / 2-\text { solution }}$ changed in the order: sugars $>$ amino acids > carboxylic acids (Table 8-2). Glucose and fructose showed a similar $T_{1 / 2-\text { solution }}\left(3.8 \mathrm{~min}\right.$ ), which was 1.5 - 2 times longer than for other the substances. The lowest $T_{1 / 2-}$ solution $(<1 \mathrm{~min}$ ) was found for formic acid. Estimates of the total amount of LMWOS ascribed to modelled pool $a_{2}$ were similar for all substances (Table 8-2).

Table 8-2. Single first order kinetic coefficients describing the depletion of individual carbon substrates from soil solution over time.

\begin{tabular}{lccccc}
\hline Substrate & $\begin{array}{c}\text { C oxidation } \\
\text { state }\end{array}$ & $\begin{array}{c}\text { Pool } a_{1} \\
(\%)\end{array}$ & $\begin{array}{c}\text { Pool } a_{2} \\
(\%)\end{array}$ & $\begin{array}{c}k \\
\left(\mathrm{~min}^{-1}\right)\end{array}$ & $\begin{array}{c}\text { Half-life, } T_{1 / 2} \\
(\mathrm{~min})\end{array}$ \\
\hline Glucose & 0 & $11.9 \pm 4.3$ & $91.6 \pm 7.0$ & $0.18 \pm 0.03^{\mathrm{d}}$ & $3.85 \pm 0.12^{\mathrm{a}}$ \\
Fructose & 0 & $13.9 \pm 4.4$ & $91.1 \pm 6.9$ & $0.18 \pm 0.01^{\mathrm{d}}$ & $3.76 \pm 0.12^{\mathrm{a}}$ \\
Formic acid & +2 & $8.9 \pm 0.9$ & $91.0 \pm 2.1$ & $1.12 \pm 0.11^{\mathrm{a}}$ & $0.62 \pm 0.08^{\mathrm{e}}$ \\
Malic acid & +1 & $12.3 \pm 1.6$ & $87.4 \pm 3.8$ & $0.68 \pm 0.08^{\mathrm{b}}$ & $1.03 \pm 0.08^{\mathrm{d}}$ \\
Succinic acid & +0.5 & $10.9 \pm 2.2$ & $88.5 \pm 4.9$ & $0.49 \pm 0.06^{\mathrm{bc}}$ & $1.42 \pm 0.09^{\mathrm{c}}$ \\
Alanine & 0 & $7.7 \pm 1.9$ & $93.6 \pm 4.1$ & $0.46 \pm 0.05^{\mathrm{bc}}$ & $1.51 \pm 0.07^{\mathrm{c}}$ \\
Glycine & +1 & $12.0 \pm 2.4$ & $86.8 \pm 5.1$ & $0.35 \pm 0.05^{\mathrm{c}}$ & $1.97 \pm 0.09^{\mathrm{b}}$ \\
\hline
\end{tabular}

$a_{1}$ is an asymptote to which ${ }^{14} \mathrm{C}$ activity fells in single exponential curves, $a_{2}$ is an estimated pool size for uptake, and $k$ is an uptake rate constant. Half-life $\left(T_{1 / 2}\right)$ values are derived from the parameter values for $k$. Values represent means \pm SE $(n=4)$. Letters reflect significant differences between the substances, confidential interval $=84 \%$. For $a_{1}$ and $a_{2}$ no significant differences were found. 


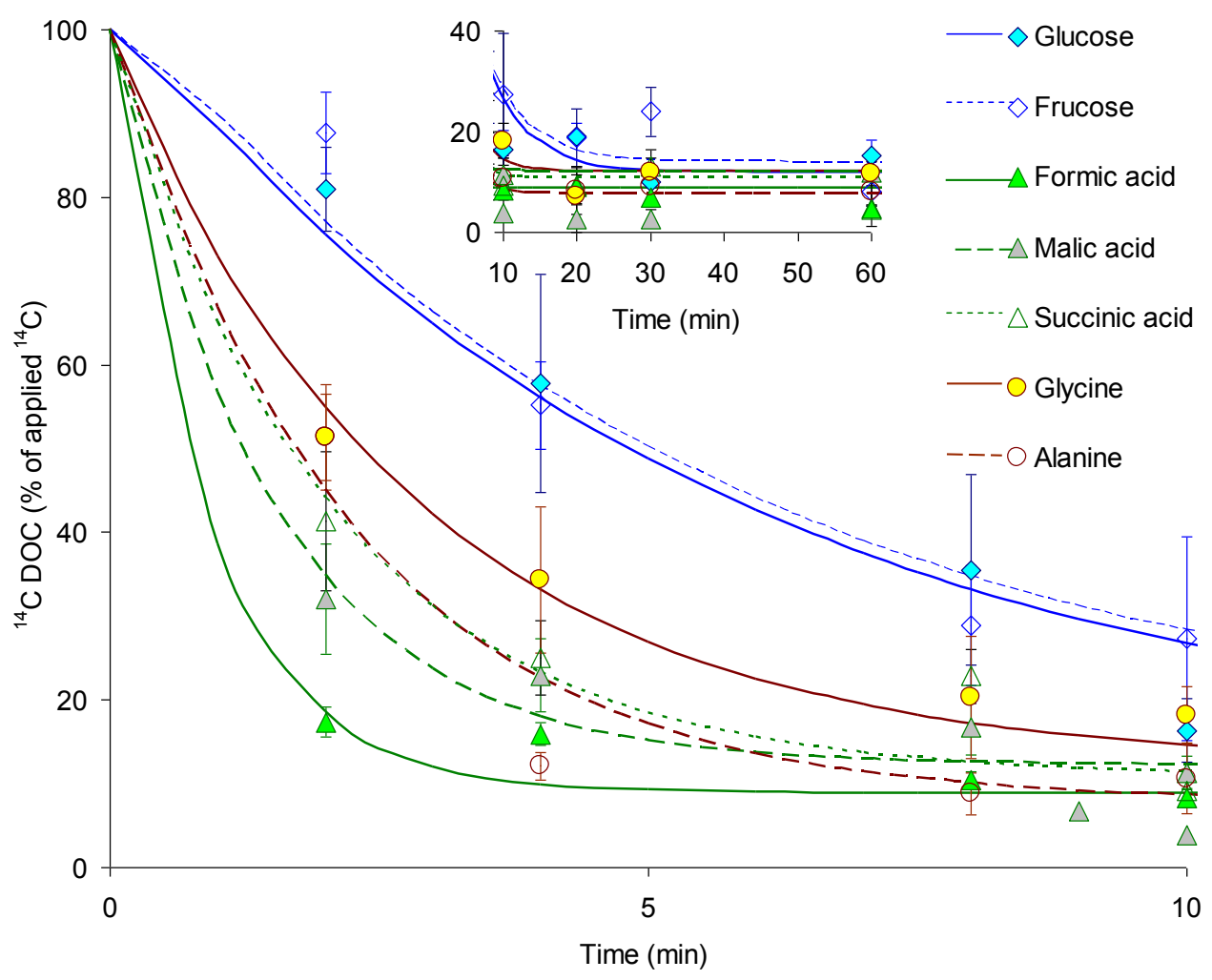

Figure 8-1. Temporal dynamics of ${ }^{14}$ C-labelled sugar, organic acid and amino acid disappearance from soil solution. Values represent means $\pm S E(n=4)$. Lines are the following: blue: solid - glucose, dotted-fructose; green: solid-formic acid, dashed-malic acid, dotted - succinic acid; brown: solid - glycine, dashed - alanine.

There was a negative relationship between the $T_{1 / 2-\text { solution }}$ of each substrate and its $\mathrm{C}$ oxidation state (Fig. 8-2 top panel) and number of -COOH groups (Supplementary material; Fig. 8-1). Furthermore, there was a positive relationship between the $T^{1 / 2}$-solution of all LMWOS and the number of $\mathrm{C}$ atoms within the individual substrates (Fig. 8-2, bottom panel). Results for the autoclaved soil (Supplementary material; Fig. 8-2) showed some dilution with the intrinsic soil solution and that sorption can occur for some substances (e.g. carboxylic acids and, glycine). However, as shown previously (Fischer et al., 2010), biotic uptake of LMWOS out-competes the abiotic sorption processes, from which we predict that sorption processes will not greatly influence the results in the non-autoclaved soil. 


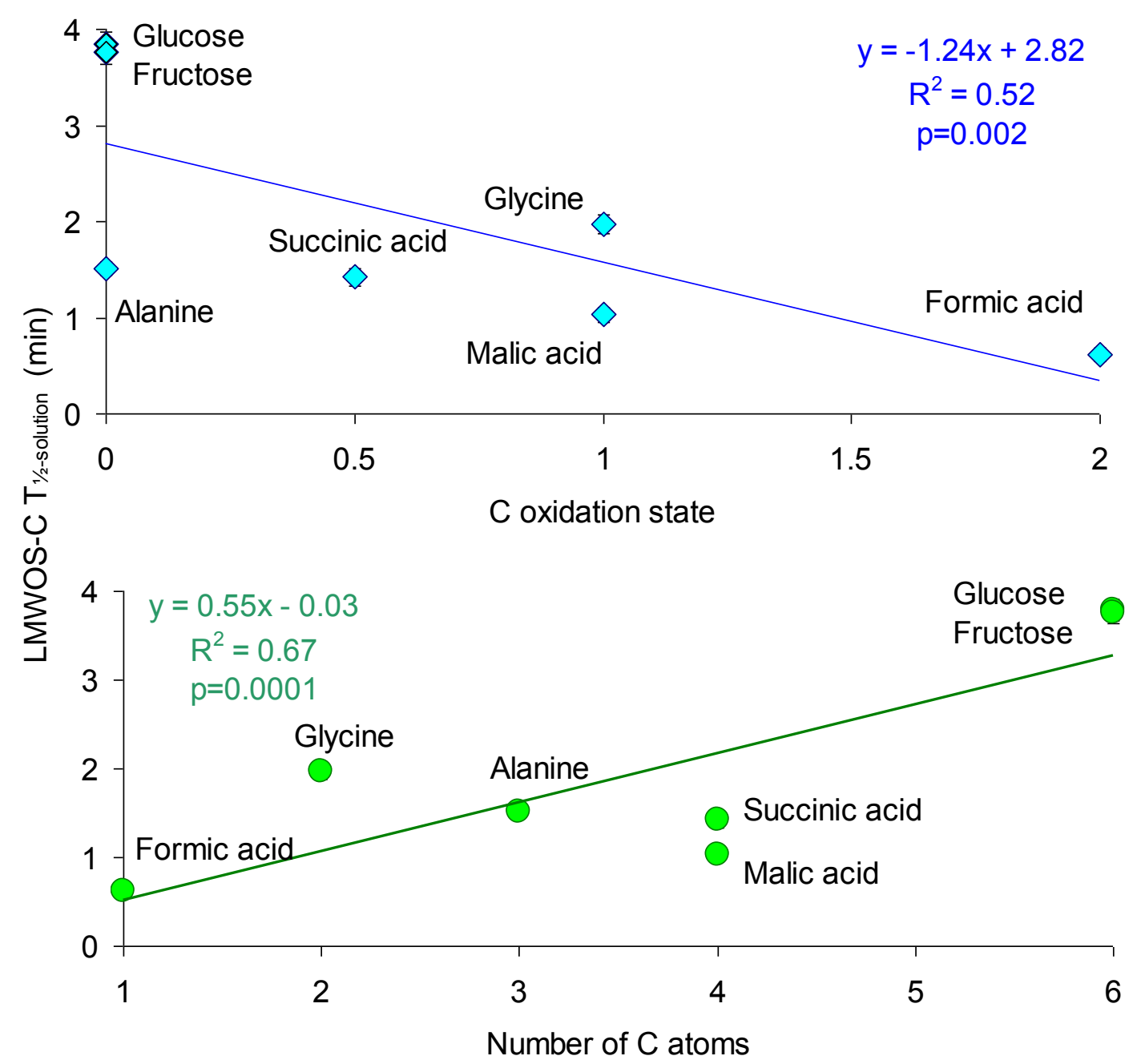

Figure 8-2. Relationship between the half-life (min) of different LMWOS in soil solution and their C oxidation state (top panel) and number of $C$ atoms in the molecule (bottom panel). Values represent means $\pm S E(n=4)$. The error bars for the half-life times of LMWOS in DOC are smaller than size of icon symbols.

\subsection{Mineralization of LMWOS in soil}

Mineralization patterns were similar for all three LMWOS classes, namely the highest portion of $\mathrm{C}$ was mineralized in the first $5 \mathrm{~h}$, and later ${ }^{14} \mathrm{C}-\mathrm{CO}_{2}$ reached a plateau (Fig. 8-3). The maximum proportion of mineralized LMWOS was found for carboxylic acids, followed by amino acids and sugars (Fig. 8-3). Overall, 15 to $80 \%$ of the applied LMWOS were decomposed to $\mathrm{CO}_{2}$ within the first mineralization phase (pool $a, k_{\mathrm{a}}$ ) depending on substance class (Fig. 8-3). Constant rates for the first mineralization phase were between 0.5 and $1.3 \% \mathrm{~h}^{-1}$ and calculated $T_{1 / 2 \text {-fast }}$ values for pool $a$ for each LMWOS-C were in the range of 0.52-1.34 h (30-80 min) (Table 8-3), with the shortest values observed for malic acid and the longest for glycine. The $T_{1 / 2 \text {-fast }}$ values for each 
LMWOS-C were much longer than those calculated for their loss from soil solution, showing that mineralization does not occur immediately after LMWOS uptake. No significant correlation was

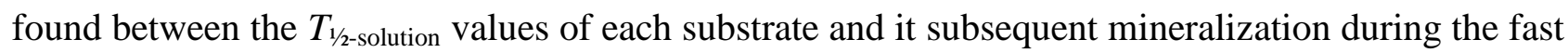
utilization phase (Supplementary materials; Fig. 8-3).

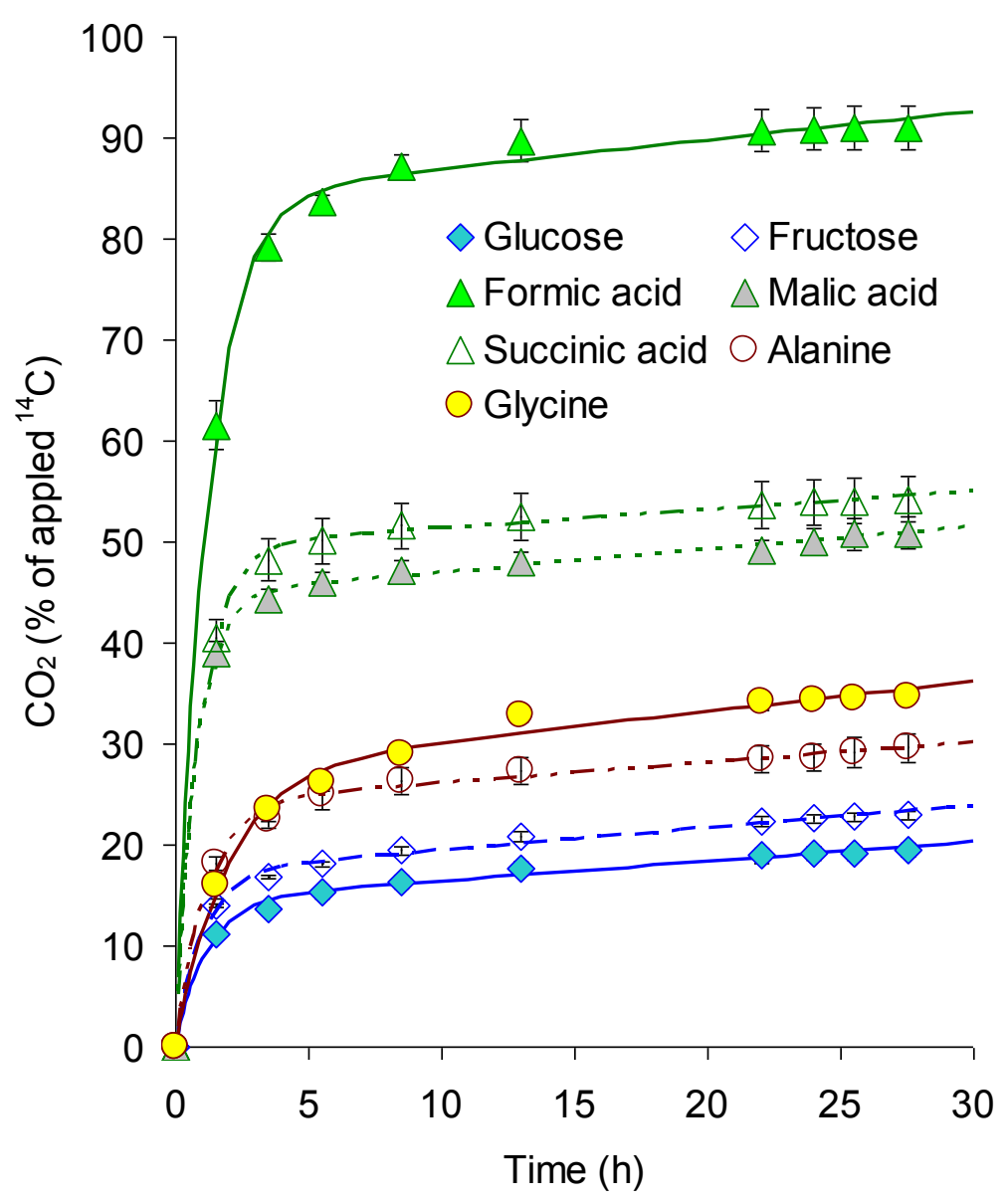

Figure 8-3. Cumulative ${ }^{14} \mathrm{C}$-CO $\mathrm{CO}_{2}$ production from mineralization of ${ }^{14} \mathrm{C}$-labelled substances in soil. Values represent means $\pm S E(n=4)$.

Constant rates for the second mineralization phase (model pool $b, k_{\mathrm{b}}$; Table 8-3), which describes the turnover of substrate-C immobilized in the microbial biomass, were up to 3 orders of magnitude lower than for the first modeled pool $\left(a, k_{\mathrm{a}}\right)$. Calculated LMWOS-C $T_{1 / 2-\text { slow }}$ ranged between 25 and $290 \mathrm{~h}$, with the shortest values observed for formic acid and the longest for glucose. The $T_{1 / 2 \text {-slow }}$ values for each LMWOS showed relationships with $\mathrm{C}$ oxidation state and number of $\mathrm{C}$ atoms (Supplementary material; Fig. 8-5). 
Table 8-3. Double first order kinetic coefficients describing the depletion of individual carbon substrates from soil over time.

\begin{tabular}{lcccccc}
\hline Substrate & $\begin{array}{c}\text { Pool } a \\
(\%)\end{array}$ & $\begin{array}{c}\text { Pool } b \\
(\%)\end{array}$ & $\begin{array}{c}k_{\mathrm{a}} \\
\left(\mathrm{h}^{-1}\right)\end{array}$ & $\begin{array}{c}k_{\mathrm{b}} \\
\left(\mathrm{h}^{-1}\right)\end{array}$ & $\begin{array}{c}k_{\mathrm{a}} T_{1 / 2} \\
(\mathrm{~h})\end{array}$ & $\begin{array}{c}k_{\mathrm{b}} T_{1 / 2} \\
(\mathrm{~h})\end{array}$ \\
\hline Glucose & $14.3 \pm 0.7^{\mathrm{d}}$ & $85.6 \pm 0.5^{\mathrm{a}}$ & $0.88 \pm 0.12^{\mathrm{ab}}$ & $0.0024 \pm 0.0003^{\mathrm{c}}$ & $0.79 \pm 0.10^{\mathrm{bc}}$ & $288.8 \pm 0.09^{\mathrm{a}}$ \\
Fructose & $17.1 \pm 0.5^{\mathrm{d}}$ & $82.9 \pm 0.3^{\mathrm{b}}$ & $1.01 \pm 0.08^{\mathrm{ab}}$ & $0.0028 \pm 0.0002 \mathrm{~b}^{\mathrm{c}}$ & $0.68 \pm 0.06^{\mathrm{bc}}$ & $247.6 \pm 0.05^{\mathrm{b}}$ \\
Formic acid & $82.8 \pm 2.5^{\mathrm{a}}$ & $17.2 \pm 1.9^{\mathrm{g}}$ & $0.87 \pm 0.07^{\mathrm{b}}$ & $0.0270 \pm 0.0070^{\mathrm{a}}$ & $0.80 \pm 0.05^{\mathrm{b}}$ & $25.7 \pm 0.19^{\mathrm{e}}$ \\
Malic acid & $44.6 \pm 1.4^{\mathrm{b}}$ & $55.4 \pm 0.9^{\mathrm{d}}$ & $1.33 \pm 0.14^{\mathrm{a}}$ & $0.0044 \pm 0.0008^{\mathrm{b}}$ & $0.52 \pm 0.08^{\mathrm{c}}$ & $157.5 \pm 0.13^{\mathrm{d}}$ \\
Succinic acid & $49.4 \pm 2.5^{\mathrm{b}}$ & $50.6 \pm 1.6^{\mathrm{e}}$ & $1.11 \pm 0.17 \mathrm{a}^{\mathrm{b}}$ & $0.0039 \pm 0.0020^{\mathrm{bc}}$ & $0.63 \pm 0.11^{\mathrm{bc}}$ & $177.7 \pm 0.31^{\mathrm{c}}$ \\
Alanine & $23.9 \pm 1.5^{\mathrm{c}}$ & $76.0 \pm 1.0^{\mathrm{c}}$ & $0.86 \pm 0.15^{\mathrm{ab}}$ & $0.0028 \pm 0.0007^{\mathrm{bc}}$ & $0.81 \pm 0.11^{\mathrm{bc}}$ & $247.6 \pm 0.18^{\mathrm{b}}$ \\
Glycine & $26.7 \pm 1.2^{\mathrm{c}}$ & $73.0 \pm 1.0^{\mathrm{c}}$ & $0.52 \pm 0.06^{\mathrm{c}}$ & $0.0044 \pm 0.0007^{\mathrm{b}}$ & $1.34 \pm 0.07^{\mathrm{a}}$ & $157.5 \pm 0.11^{\mathrm{d}}$ \\
\hline Plycin
\end{tabular}

Pool $a$ and $b$ are the estimated pool sizes for the fast and slow mineralization phases respectively, while $k_{\mathrm{a}}$ and $k_{\mathrm{b}}$ are the rate constants describing the rate of turnover of these two pools. $T_{1 / 2}$ values are the half-times for pools $a$ and $b$ determined from $k_{\mathrm{a}}$ and $k_{\mathrm{b}}$ respectively. Values represent means $\pm \mathrm{SE}(n=4)$. Letters reflect significant differences between the substances, confidential interval $=84 \%$.

The partitioning of LMWOS-C between $\mathrm{CO}_{2}$, the microbial cytosol and that remaining in SOC is shown in Figure 8-4. The maximum proportion of mineralized substances was observed for formic acid, which was followed by malic and succinic acid, amino acids and sugars. In contrast, the ${ }^{14} \mathrm{C}$ recovered in the cytosol and remaining in SOC followed the opposite trend. The proportion of mineralized LMWOS increased with substance $\mathrm{C}$ oxidation state, whereas the amount of ${ }^{14} \mathrm{C}$ incorporated into the cytosol and remaining in SOC (for all substances) followed the opposite trend (Fig. 8-4, top panel). Additionally, the proportion of LMWOS-C incorporated into the microbial cytosol increased with the number of $\mathrm{C}$ atoms present in the molecule and decreased with the number of - $\mathrm{COOH}$ groups (Fig. 8-4, bottom panel). 

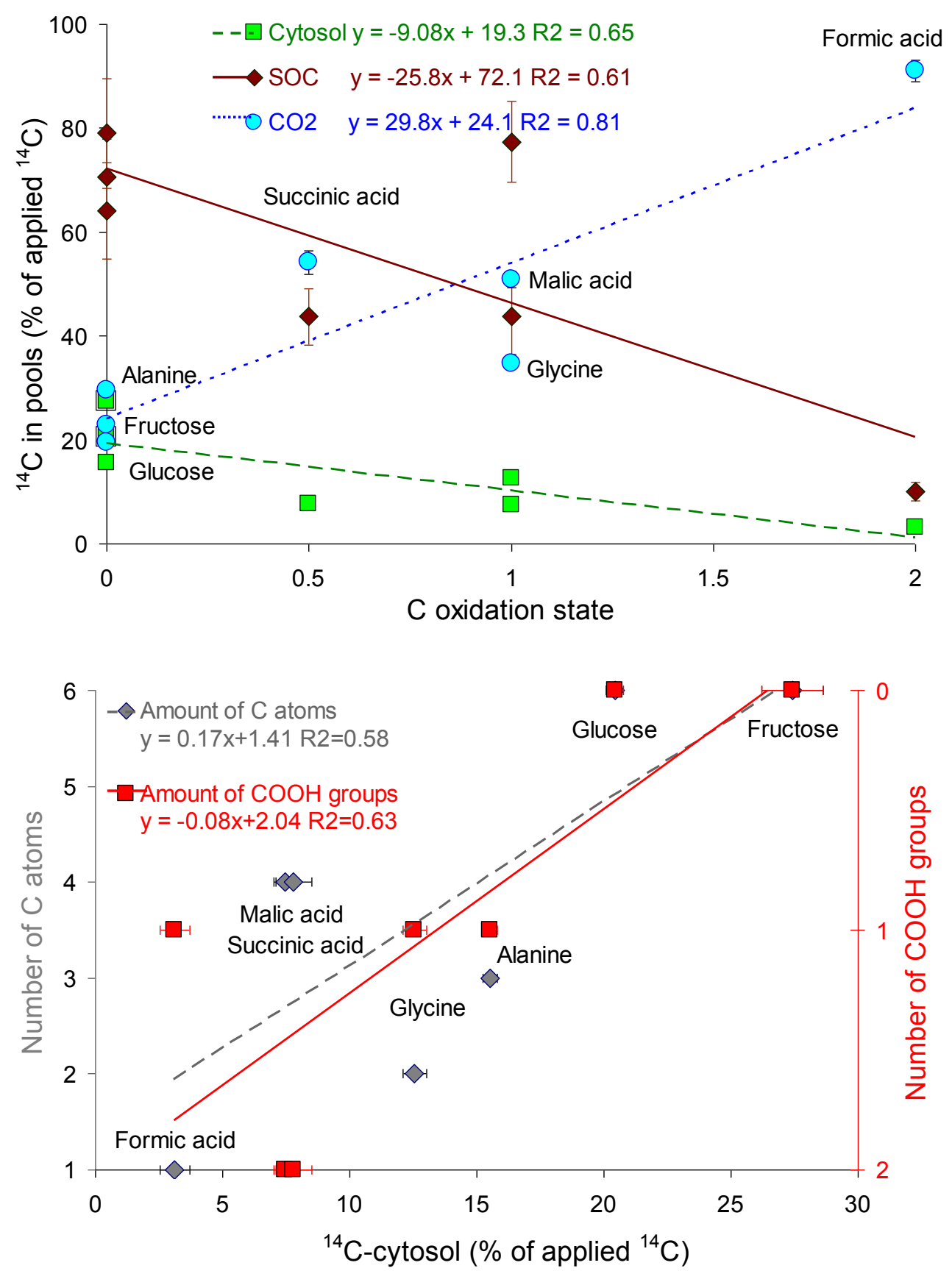

Figure 8-4. Relationship between ${ }^{14} \mathrm{C}$ remaining in the cytosol, $\mathrm{SOC}$ and $\mathrm{CO}_{2}$ pools and $\mathrm{C}$ oxidation state (top panel) and ${ }^{14} \mathrm{C}$ remaining in the cytosol and number of $C$ atoms and -COOH groups (bottom panel) in different LMWOS. Values represent means $\pm S E(n=4)$. P-values for the regression lines on the top panel figure are less than 0.002; p-values for the regression lines on the bottom panel figure are less than 0.004. The substance names are shown only once. 
Anabolism/catabolism ratio (Fig. 8-5) was the highest for the sugars (both glucose and fructose) and for alanine, having zero $\mathrm{C}$ substance oxidation states. The lowest value was found for formic acid.

Overall, initial utilization of LMWOS within the microbial biomass was not dependent on the substance properties. In contrast, the total amount of LMWOS-C which can be utilized (including mineralization to $\mathrm{CO}_{2}$ and incorporation in to cellular compounds) within the microbial biomass was clearly dependent on the physico-chemical properties of the individual substrates.

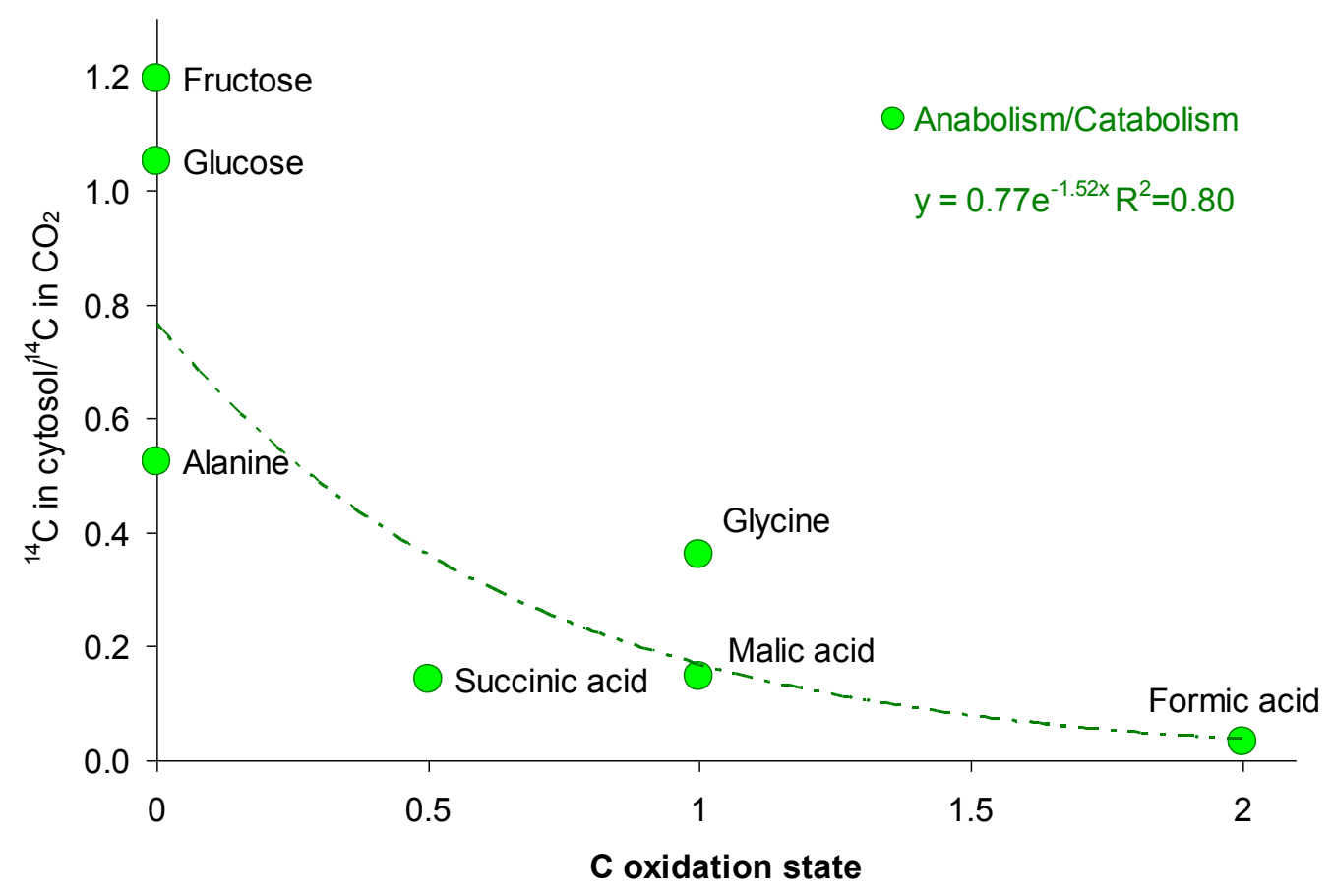

Figure 8-5. Relationship between ${ }^{14} \mathrm{C}$ incorporated into cytosol (anabolism) $/{ }^{14} \mathrm{C}$ incorporated into $\mathrm{CO}_{2}$ (catabolism) and C oxidation state at the end of LMWOS mineralization experiment.

\section{Discussion}

In this study, the utilization of LMWOS in soil focused on: i) the initial rate of uptake from soil solution, ii) mineralization to $\mathrm{CO}_{2}$, and iii) subsequent utilization and partitioning of $\mathrm{C}$ within the microbial cells. These processes were studied within $24 \mathrm{~h}$, to deduce the initial fate of LMWOS$\mathrm{C}$ rather than the turnover of secondary metabolites within the microbial community or the turnover of the biomass itself (i.e. necromass). The fate and flux of LMWOS was studied at natural concentrations (soil solution was only labeled at trace levels for each ${ }^{14} \mathrm{C}$-compound), to best reflect conditions which naturally exist in the field. This contrasts with almost all previous studies which have used high substrate addition rates to investigate LMWOS turnover in the soil. Although these 
former studies may reflect pulse additions of soluble $\mathrm{C}$ arising from root lysis or organic waste addition, they misrepresent the much lower concentrations of LMWOS produced by the slower turnover of more recalcitrant (and arguably more important) pools of soil organic matter.

\subsection{Uptake of LMWOS from soil solution}

We found that up to $90 \%$ of the applied LMWOS were taken up from soil solution within the first 10 minutes (Fig. 8-1). Similar results have been found for glucose applied to soil in the concentration range from $1 \mu \mathrm{M}$ to $10 \mathrm{mM}$ (Hill et al., 2008). The rapid removal of substrates can be attributed to the rapid uptake of LMWOS by the C-limited soil microbial community, extracellular enzymatic decomposition or sorption on the mineral phases. For most neutral or monovalent LMWOS, microorganisms represent the dominate loss pathway from solution, particularly in comparison to sorption to mineral phases (Fischer et al., 2010). In the case of di- and tri-valent substrates, however, sorption can significantly suppress microbial uptake, especially in soils containing large amounts of Fe and Al oxyhydroxides (Jones and Edwards, 1998), however, it was not the case in our study. We attempted here to estimate the effect of abiotic sorption processes by measuring the loss of LMWOS under sterile (autoclaved) and non-sterile soil. Sorption had low importance in the fate of LMWOS because larger percent of ${ }^{14} \mathrm{C}$ was removed from soil solution in non-sterile soil compare to sterile for the same time interval. This is the consequence of neutral $\mathrm{pH}$ values and low contents of $\mathrm{Fe}$ and $\mathrm{Al}$ in the soil. Overall, our results are consistent with microbial transformation being the dominant process. Although extracellular enzymes may exist in soil solution and could extracellularly cleave our substrates (e.g. deaminases acting on alanine or glycine to produce pyruvate and lactate), we expect this transformation pathway to be insignificant in comparison to the direct uptake by microbial membrane transporters.

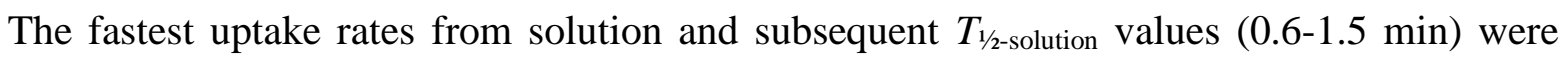
found for carboxylic acids while the slowest $T_{1 / 2-\text { solution }}$ value was found for sugars $(3.7 \mathrm{~min}$ ) (Table 8-2). Although the rate of depletion was very rapid for all substrates, the variation in uptake rate can be attributed to differences in (i) relative diffusion speed of the substrates in solution, (ii) different affinities and expression of the various transport systems within the microbial community, and (iii) rate of intracellular processing of the various substrate classes which may feedback on transporter activity (Hill et al., 2008; Jones and Edwards, 1998). The $T_{1 / 2 \text {-solution }}$ of carboxylic and amino acids decreased with the $\mathrm{C}$ oxidation state of substances suggesting that LMWOS with low $\mathrm{C}$ oxidation states remain in soil solution longer than ones which are highly oxidized. At the same 


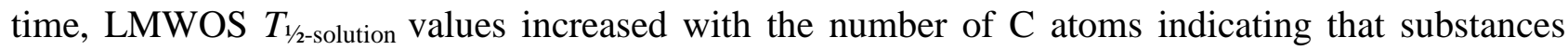
with a lower molecular weight are taken up faster. For substances with a similar $\mathrm{C}$ oxidation state

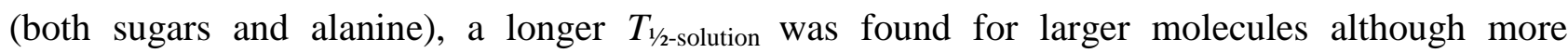
substrates would need to be tested to confirm this. Overall, even if the substance class is one of the significant parameter determining the fate of LMWOS in soil solution (Gunina et al., 2014), we conclude that the $T_{1 / 2-\text { solution }}$ of LMWOS depends also on substance $\mathrm{C}$ oxidation state and on molecular size. Further, the very rapid uptake of all LMWOS classes from soil solution suggests that this is not the limiting step of their initial utilization by microorganisms.

\subsection{Mineralization of LMWOS}

The $T_{1 / 2 \text {-fast }}$ values, describing the initial transformation of LMWOS-C within the microbial biomass, were 30-80 times higher than the $T_{1 / 2-\text { solution }}$ values, indicating that mineralization may occur more slowly than cellular uptake. However, we added tracer amounts of substrate to extracted soil solution which was then injected to the soil to try and mimic natural $\mathrm{C}$ concentrations. Therefore, we would expect the system to be at quasi-steady state (i.e. a stable microbial biomass) and the rate of $\mathrm{C}$ influx into soil solution should be equal to the rate of $\mathrm{C}$ efflux from the microbial biomass. However, it was not the case in our study and observed slow rate of $\mathrm{C}$ efflux and high values of $T_{1 / 2-}$ fast could be due to i) dilution of the LMWOS in the labile metabolite pool within the cytosol (Hill et al., 2008), and ii) passage of LMWOS through contrasting metabolic pathways which enter aerobic or anaerobic respiratory cycles at different points. Additionally, natural artifacts such as release of $\mathrm{HCO}_{3}{ }^{-}$from the cell, its diffusion through extracellular water films and the subsequent degassing and diffusion of $\mathrm{CO}_{2}$ through the pore network to the soil surface can effect on the temporal dynamic of captured $\mathrm{CO}_{2}$ (Boddy et al., 2007). However, due to the small amount of soil, which was used in the present experiment, these artifacts should not strongly affect our results, but would need to be accounted for when working with large undisturbed field samples. This highlights the intrinsic problems associated with sole reliance on quantifying substrate turnover rates based on mineralization data alone, especially for short-lived substrates. It also indicates that previous studies may have vastly underestimated substrate turnover rates (van Hees et al., 2002).

An absence of dependence between LMWOS-C $T_{1 / 2 \text {-fast }}$ and $\mathrm{C}$ oxidation state, number of $\mathrm{C}$ atoms, or number of - $\mathrm{COOH}$ groups of the substances (Supplementary material; Fig. 8-4) are likely due to incorporation of LMWOS into various metabolic pathways within the microorganisms (Gunina et al., 2014; Apostel et al., 2013; Apostel et al., 2015; Dippold and Kuzyakov, 2013; 
Dijkstra et al., 2011). So, calculated alanine $\mathrm{C}_{\mathrm{1} / 2 \text {-fast }}$ was 1.5 times faster than glycine (Table 8-3). This could be explained as alanine enters the citric acid cycle as pyruvate, whereas glycine is metabolized in the cells via three different pathways: i) by glycine cleavage enzyme, ii) by conversion of glycine to pyruvate via serine and iii) by conversion of glycine to glyoxylate by Lamino acid oxidase or L-amino acid dehydrogenase (Keseler et al., 2009), thus, glycine-C can be metabolized slower than alanine. In contrast, LMWOS-C $T_{1 / 2 \text {-slow }}$ decreased with an increase in C oxidation state and increased with the amount of $\mathrm{C}$ atoms in the LMWOS molecule, showing that more time is needed to oxidize the LMWOS with a low $\mathrm{C}$ oxidation state. Thus, the initial mineralization processes of LMWOS by soil microorganisms are mainly connected with the point at which compounds enter into metabolic cycles, whereas subsequent utilization of LMWOS-derived $\mathrm{C}$ can be affected by properties of the substances.

\subsection{Partitioning of LMWOS-C between the $\mathrm{CO}_{2}$, cytosol and SOC pools}

The amount of $\mathrm{C}$ mineralized followed the order: carboxylic acids > amino acids > sugars. This is in agreement with some previous laboratory and field studies (Jones and Edwards, 1998), but contrasts with others where no differences were observed (Gunina et al., 2014). Such contradictory results are connected with i) various observation periods used during the studies, ii) the amount of time elapsed between LMWOS application and the start of sampling, and iii) various half-life time of cell metabolites, where LMWOS-C was incorporated. Additionally, the total amount of LMWOS applied to the soil can affect the amount of substrate mineralized, especially if the amount added is sufficient to stimulate microbial growth. Typically, when concentrations of LMWOS exceed $10 \mathrm{mM}$ the amount of $\mathrm{C}$ incorporated into microbial biomass compartments increases and less $\mathrm{C}$ is respired (Hill et al., 2008). In this study, the proportion of substrate-C mineralized increased with the $\mathrm{C}$ oxidation state of the substances (Fig. 8-4, top panel, Fig. 8-6), showing that oxidized compounds are used preferentially for respiration with less $\mathrm{C}$ incorporated into cell metabolites. 


\section{C oxidation state}

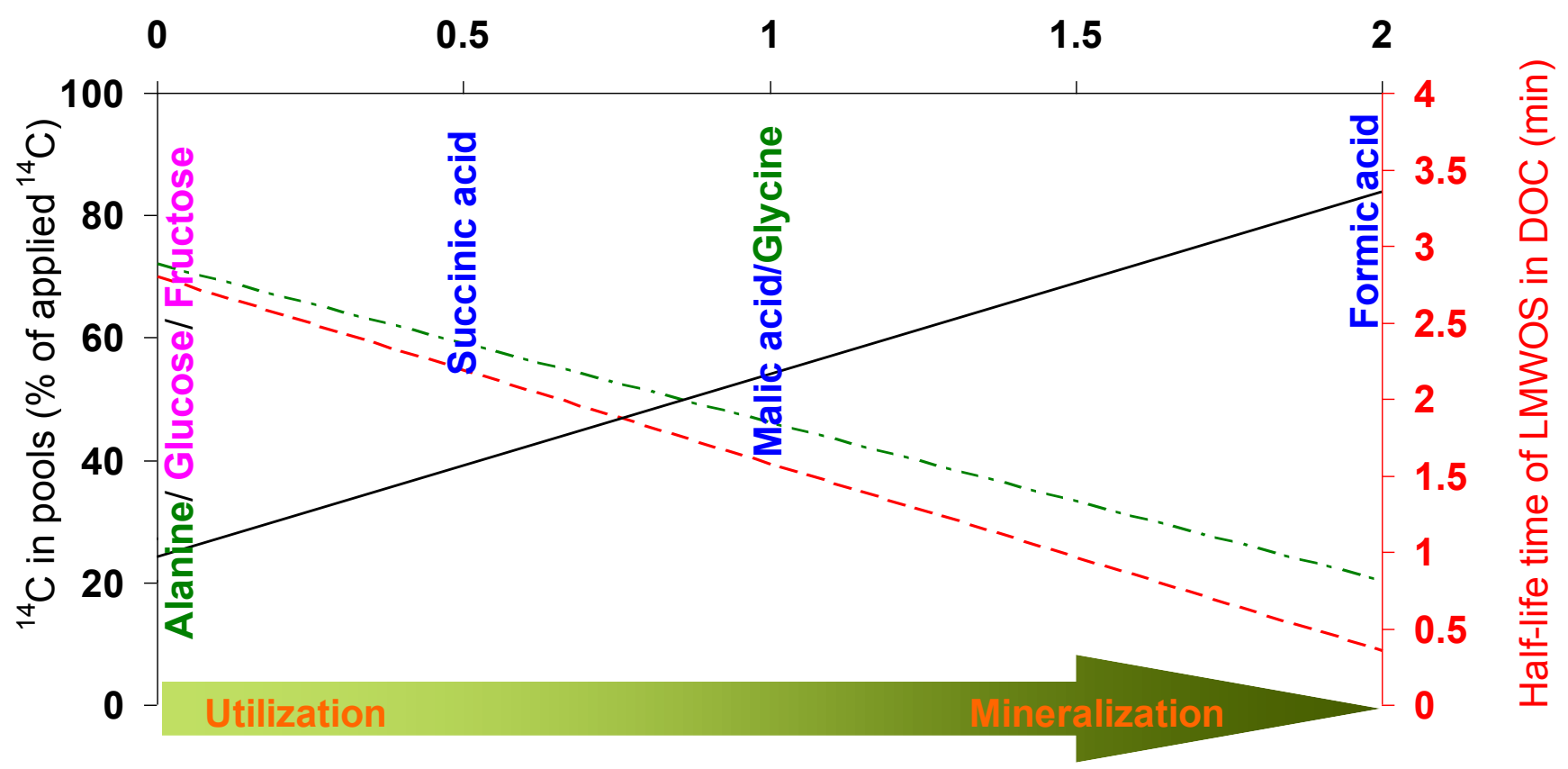

Figure 8-6. Schematic representation showing the dependence of microbial uptake rate (red), utilization (green) and mineralization efficiency (black) of three distinct classes of LMWOS as a function of substrate $C$ oxidation state.

The highest portion of ${ }^{14} \mathrm{C}$-LMWOS recovered from the cytosol pool was from sugars, suggesting that sugars are the universal compounds for construction of cell components (constituents of the bacterial and fungal cell membranes and cell walls, lipoteichoic and teichoic acids of Gram-positive bacteria, lipopolysaccharides of Gram-negative bacteria, polysaccharides, etc) (Dippold et al., 2014; Gunina and Kuzyakov, 2015; Lengeler et al., 1999). In contrast, the lowest incorporation of ${ }^{14} \mathrm{C}$-LMWOS found in the cytosol was from carboxylic acids, with the lowest of that group being formic acid (Fig. 8-4, Supplementary material; Fig. 8-6). Reported ratios of mineralized-C to immobilized-C for carboxylic acids is 3:2 (Jones and Edwards, 1998). A wider range of mineralized-to-immobilized $\mathrm{C}$ was reported for formic acid - 19:1 (Herlihy et al., 1987) and our results (Fig. 8-4, Supplementary material; Fig. 8-6) are in accordance with these findings. Such high mineralization can be explained by the fact that formic acid is a toxic substance (Herlihy et al., 1987), and thus, even if it is taken up by microorganisms it is mainly decomposed to $\mathrm{CO}_{2}$ within the cells. The proportion of $\mathrm{C}$ incorporated into the cytosol decreased with the substance $\mathrm{C}$ oxidation state (Fig. 8-4, top panel), suggesting that more oxidized compounds are mainly used for respiration, whereas reduced compounds are utilized for cell biomass construction. Thus, despite 
the initial LMWOS mineralization dynamics being independent of substance properties, the final partitioning of the LMWOS-C between mineralized and immobilized pools is dependent on their physiochemical properties.

Anabolism/catabolism ratio (Fig. 8-5) declined as $\mathrm{C}$ oxidation state increased, suggesting that losses for respiration prevail during the assimilation of $\mathrm{C}$ from oxidized substances or functional groups (e.g. - $\mathrm{COOH}$ ). This is directly connected with energy production, which microorganisms can obtain during utilization of LMWOS - with C oxidation state increases, energy content of the LMWOS decreases. Thus, it shows that substrates with high oxidation state are used primarily for energy, whereas substrates with low $\mathrm{C}$ oxidation state are primarily used for cell construction and maintenance.

\section{Conclusions}

Typically, the turnover of individual LMWOS in soil is estimated by measuring the rate of $\mathrm{CO}_{2}$ appearance after substrate addition to soil (i.e. substrate-induced respiration). However, this approach fails to realistically capture the dynamics of LMWOS in soil. In this study, the uptake of three common classes of LMWOS (sugars, carboxylic and amino acids) from soil solution and their subsequent mineralization by the soil microbial community was studied over a $24 \mathrm{~h}$ period. While previous studies have mainly focused on the effect of substance class or concentrations, in the present study the main focus was on the physico-chemical properties of substances, including substance $\mathrm{C}$ oxidation state, number of $-\mathrm{COOH}$ groups and $\mathrm{C}$ atoms. We combined the use of substrates at natural abundance with repeated measurements over short time scales. This allowed us to estimate actual rates of LMWOS loss from solution rather than the processing of $\mathrm{C}$ once it had already been incorporated into cell metabolites.

The half-life of the LMWOS in soil solution ranged from 0.5 to $3.8 \mathrm{~min}$, with the shortest for carboxylic acids and the longest for sugars. Thus, the extremely fast microbial uptake of all LMWOS classes from solution suggests that this is not a rate-limiting step in the utilization of LMWOS by the microbial community. The $T_{1 / 2}$ of the LMWOS in solution decreased with C oxidation state. In contrast, the $T_{1 / 2}$ of LMWOS in soil solution increased with the number of C atoms showing that larger molecules persist longer, possibly due to their slower rate of diffusion in soil. Our data suggests that the uptake of common LMWOS from soil solution by microorganisms may be possible to predict from the physio-chemical properties of the substance. 
The LMWOS-C $T_{1 / 2 \text {-fast }}$ values ranged between 30 and $80 \mathrm{~min}$ and was lowest for amino acids and highest for carboxylic acids. Large differences between LMWOS $T_{1 / 2}$ values in solution and in soil shows that microbial uptake and subsequent mineralization of LMWOS are temporarily decoupled. The $T_{1 / 2 \text { fast }}$ of LMWOS-C in soil was not dependent on the properties of the substance, from which we infer that intercellular metabolism is the main factor determining initial mineralization of $\mathrm{C}$ derived from LMWOS.

The total proportion of $\mathrm{C}$ mineralized from each LMWOS increased with the substance's $\mathrm{C}$ oxidation state, suggesting that oxidized compounds are mineralized to a greater degree than more reduced compounds. To support this observation, the LMWOS-C $T_{1 / 2 \text {-slow }}$ decreased with C oxidation state increase. The portion of LMWOS-C incorporated into the cytosol and remaining in SOC decreased with each substance's C oxidation state. Thus, substance properties directly affected the final partitioning of LMWOS-C between mineralized and microbially utilized pools. The anabolism/catabolism ratio decreased with compound $\mathrm{C}$ oxidation state, showing that more oxidized substances are mainly mineralized, whereas less oxidized LMWOS are primarily used by microorganisms for cell construction and maintenance.

\section{Acknowledgements}

This study was supported by a scholarship from the Erasmus Mundus Joint Doctoral Programme "Forest and Nature for Society" (FONASO) awarded to A. Gunina. This study was supported by the German Research Foundation (FOR 918) within the Research Unit "Carbon Flow in Belowground Food Webs assessed by Isotope Tracers" (project KU 1184/13-2). 


\section{References}

Ahmed, I.U., Smith, A.R., Jones, D.L., Godbold, D.L., 2016. Tree species identity influences the vertical distribution of labile and recalcitrant carbon in a temperate deciduous forest soil. Special Section: Forests, Roots and Soil Carbon. Forest Ecology and Management 359, 352-360.

Apostel, C., Dippold, M., Kuzyakov, Y., 2015. Biochemistry of hexose and pentose transformations in soil analyzed by position-specific labeling and ${ }^{13}$ C-PLFA. Soil Biology and Biochemistry 80 , 199-208.

Apostel, C., Dippold, M.A., Glaser, B., Kuzyakov, Y., 2013. Biochemical pathways of amino acids in soil. Assessment by position-specific labeling and ${ }^{13}$ C-PLFA analysis. Soil Biology \& Biochemistry 67, 31-40.

Blagodatskaya, E., Kuzyakov, Y., 2013. Active microorganisms in soil: critical review of estimation criteria and approaches. Soil Biology \& Biochemistry 67, 192-211.

Boddy, E., Hill, P.W., Farrar, J., Jones, D.L., 2007. Fast turnover of low molecular weight components of the dissolved organic carbon pool of temperate grassland field soils. Soil Biology \& Biochemistry 39, 827-835.

Dijkstra, P., Dalder, J.J., Selmants, P.C., Hart, S.C., Koch, G.W., Schwartz, E., Hungate, B.A., 2011. Modeling soil metabolic processes using isotopologue pairs of position-specific ${ }^{13} \mathrm{C}$ labeled glucose and pyruvate. Soil Biology \& Biochemistry 43, 1848-1857.

Dippold, M.A., Boesel, S., Gunina, A., Kuzyakov, Y., Glaser, B., 2014. Improved delta C-13 analysis of amino sugars in soil by ion chromatography-oxidation-isotope ratio mass spectrometry. Rapid Communications in Mass Spectrometry 28, 569-576.

Dippold, M.A., Kuzyakov, Y., 2013. Biogeochemical transformations of amino acids in soil assessed by position-specific labelling. Plant and Soil DOI 10.1007/s11104-013-1764-3.

Fischer, H., Ingwersen, J., Kuzyakov, Y., 2010. Microbial uptake of low-molecular-weight organic substances out-competes sorption in soil. European Journal of Soil Science 61, 504-513.

Fischer, H., Kuzyakov, Y., 2010. Sorption, microbial uptake and decomposition of acetate in soil. Transformations revealed by position-specific ${ }^{14} \mathrm{C}$ labeling. Soil Biology \& Biochemistry 42, 186-192.

Glanville, H., Rousk, J., Golyshin, P., Jones, D.L., 2012. Mineralization of low molecular weight carbon substrates in soil solution under laboratory and field conditions. Soil Biology \& Biochemistry 48, 88-95.

Glanville, H.C., Hill, P.W., Schnepf, A., Oburger, E., Jones, D.L., 2016. Combined use of empirical data and mathematical modelling to better estimate the microbial turnover of isotopically labelled carbon substrates in soil. Soil Biology and Biochemistry 94, 154-168.

Grayston, S.J., Vaughan, D., Jones, D., 1997. Rhizosphere carbon flow in trees, in comparison with annual plants. The importance of root exudation and its impact on microbial activity and nutrient availability. Applied Soil Ecology 5, 29-56.

Gunina, A., Dippold, M., Glaser, B., Kuzyakov, Y., 2014. Fate of low molecular weight organic substances in an arable soil. From microbial uptake to utilisation and stabilisation. Soil Biology \& Biochemistry 77, 304-313.

Gunina, A., Kuzyakov, Y., 2015. Sugars in soil and sweets for microorganisms. Review of origin, content, composition and fate. Soil Biology and Biochemistry doi:10.1016/j.soilbio.2015.07.021. 
Herlihy, L.J., Galloway, J.N., Mills, A.L., 1987. Bacterial utilization of formic and acetic acid in rainwater. Atmospheric Environment (1967) 21, 2397-2402.

Hill, P.W., Farrar, J.F., Jones, D.L., 2008. Decoupling of microbial glucose uptake and mineralization in soil. Soil Biology \& Biochemistry 40, 616-624.

Hill, P.W., Farrell, M., Jones, D.L., 2012. Bigger may be better in soil N cycling: does rapid acquisition of small peptides by soil microbes dominate fluxes of protein-derived $\mathrm{N}$ in soil. Soil Biology \& Biochemistry 48, 106-112.

Jones, D.L., Edwards, A.C., 1998. Influence of sorption on the biological utilization of two simple carbon substrates. Soil Biology \& Biochemistry 30, 1895-1902.

Jones, D.L., Hodge, A., 1999. Biodegradation kinetics and sorption reactions of three differently charged amino acids in soil and their effects on plant organic nitrogen availability. Soil Biology \& Biochemistry 31, 1331-1342.

Keseler, I., C, B.-M., Collado-Vides, J., Gama-Castro, S., Gunsalus, R., Johnson, D., Krummenacker, M., Nolan, L., Paley, S., Paulsen, I., Peralta-Gil, M., Santos-Zavaleta, A., Shearer, A., Karp, P., 2009. A comprehensive view of Escherichia coli biology. Nucleic Acids Research 37, D464-D470.

Kuzyakov Y., B.E., 2015. Microbial hotspots and hot moments in soil: Concept \& review. Soil Biology \& Biochemistry 83, 184-199.

Lengeler, J.W., Drews, G., Schlegel, H.G., 1999. Biology of the prokaryotes. Georg Thieme Verlag, 955.

Roels, J.A., 1980. Application of Macroscopic Principles to Microbial Metabolism. Biotechnol. Bioeng. 22, 2457-2514.

Smith A., Lukac M., Hood R., Healey J.R., Miglietta F., Godbold D.L., 2013. Elevated $\mathrm{CO}_{2}$ enrichment induces a differential biomass response in a mixed species temperate forest plantation. New Phytologist 198, 156-168.

van Hees, P. A. W., Jones, D.L., Godbold, D.L., 2002. Biodegradation of low molecular weight organic acids in coniferous forest podzolic soils. Soil Biology \& Biochemistry 34, 1261-1272.

van Hees P.A.W., Jones D.L., Finlay R., Godbold D.L, Lundström U.S., 2005. The carbon we do not see - the impact of low molecular weight compounds on carbon dynamics and respiration in forest soils: a review. Soil Biology \& Biochemistry, 37, 1-13.

Wu, J., Joergensen, R.G., Pommerening, B., Chaussod, R., Brookes, P.C., 1990. Measurement of soil microbial biomass $\mathrm{C}$ by fumigation extraction - an automated procedure. Soil Biology \& Biochemistry 22, 1167-1169. 


\section{Chapter 9}

\subsection{General discussion}

Thus, this $\mathrm{PhD}$ work has investigated various processes occurring in forest soils, including the effect of abiotic factors (MAT and MAP) on the structure of microbial communities (Chapter 3), the effect of afforestation by different tree species on the formation of microbial community structure (Chapter 4), and the function of microorganisms after afforestation (chapter 5 and 6). In addition, knowledge gaps were addressed regarding the utilization of LMWOS by microorganisms and the effect of their intrinsic physicochemical properties on this process (Chapter 8). Finally, a literature review on the fate of sugars in soil was conducted (Chapter 7).

Below, the main results and conclusions from all chapters, as well as future possible development of the investigated topics, will be presented.

The structure of microbial communities governs the allocation of $\mathrm{C}$ in soil and affects ecosystem C cycling (Schimel and Schaeffer, 2012). In turn, chemical soil properties, plant community type, and climatic variables contribute to the development of soil microbial community structure. Due to the strong interactions between climatic variables, plant communities and edaphic properties, it is difficult to reveal the main factors controlling soil microbial community structure.

In chapter 3, findings were presented regarding the effect of climatic variables on the formation of soil microbial communities in natural forests developed on similar parent material and along an elevation gradient of Mt. Kilimanjaro (from 770 until $4200 \mathrm{~m}$ ). The study of soil microbial community structure revealed a bell-shaped curve of total biomarker (PLFA) content with elevation, with a maximum at $2100 \mathrm{~m}$. A literature review showed that MAP and MAT also affect the PLFA content of other mountain ecosystems around the world. Overall, it appears that total PLFA content peaks at mid-elevations ( $2000 \mathrm{~m})$ across a broad range of ecosystems around the world. Soil microbial communities at the highest elevation ecosystems (above $3000 \mathrm{~m}$ ) were distinctly different from those at lower elevations. Gram-negative bacteria dominated the microbial community in Mt. Kilimanjaro soils, accounting for $25-40 \%$ of total PLFA, and, thus, regulating the major trend in PLFA distribution. With increasing elevation, gram-positive bacteria were replaced by fungi as a reaction to the harsh environmental conditions in the alpine zone above $4000 \mathrm{~m}$, characterized by low MAT and soil $\mathrm{C}$ and $\mathrm{N}$ contents. These variations were indirectly dependent on climatic factors, and mainly explained by changes in vegetation composition and soil parameters. It is concluded that the optimal conditions for microbial biomass in mountain soils are 
common at elevations between 1700 and $2700 \mathrm{~m}$, mainly because of the presence of an optimal combination of climatic conditions for vegetation and soil development.

The structure and function of soil microbial communities in mature forests are governed by both vegetation type and edaphic properties such as $\mathrm{SOM}, \mathrm{pH}, \mathrm{N}$ content, and other nutrient concentrations, which are unique for each forest. In contrast, the main factor effecting microbial community structure in young forests seems to be the plant community type, due to significant shifts in soil properties within a couple of decades after forest establishment. Thus, young forest soils present a unique opportunity to study the direct effect of biotic factors on the formation of microbial communities. In chapter 4, findings were presented regarding the effects of tree identity and forest community composition on soil chemistry and the structure of microbial communities 10 years after forest establishment. The study was done for mono-, bi- and tri-species forests, comprised of trees with contrasting functional traits, namely primary (birch and alder) and late successional (beech and oak) species, and $\mathrm{N}$-fixing (alder) and non-N-fixing (beech, oak and birch) species. Besides, these forest species have different density of fine roots, which is the highest for beech and the lowest for oak and alder (Supplementary materials). As a control, adjusted arable soil was also analysed. It was shown that total PLFA content increased by more than $100 \%$ in forest soils compared to the arable control, whereas changes in soil chemical properties $(\mathrm{C}$ and $\mathrm{N}$ contents, dissolved $\mathrm{N}$ forms) were altered to a lesser degree. Total PLFA content for monoculture forests (except beech) were higher than for the mixtures, indicating that species identity has a stronger effect than number of species on the content of microbial biomarkers and no additive effects of increasing species number were observed (Gunina et al., 2017a). Compared to bacterial biomarkers, the content of fungal biomarkers was changed by afforestation to a much greater extent. The increase of particular biomarkers for all forests compared to arable soil was independent of tree species amount, reflecting an absence of additive effects of forest mixtures on the content of specific microbial biomarkers. It was shown that microbial community composition in two-species forests was different from one- and three-species forests due to a higher abundance of actinomycetes and G+ bacterial biomarkers (Gunina et al., 2017a). In contrast, microbial community composition for single species forests was similar to the three-species mixtures, and was only slightly different due to a higher abundance of G- bacterial biomarkers. Thus, development of forest monocultures, even formed by species with different functional traits, promotes formation of similar microbial communities. In contrast, the simultaneous presence of early primary and late 
successional species stimulates the development of different community compositions; however, this effect is dampened in mixtures of two early primary and late successional species.

The information about changes to microbial community structure after afforestation does not provide a full picture about the shifts in rates of soil processes or nutrients dynamics. To reveal the changes in the cycling of $\mathrm{C}, \mathrm{N}$ and $\mathrm{P}$ after afforestation, activities of extracellular enzymes were measured (chapter 5) for the same sites as were used in the previous study (chapter 4). It was revealed that potential activities of $\mathrm{C}$ cycling enzymes $(\mathrm{BG})$ decreased in response to afforestation, whilst the enzyme affinity remained unchanged. Decrease of soil $\mathrm{pH}$ was a strongly correlated with decrease of BG activity, but additional factors such as a presence of tannins in the litter can suppress BG activity. In contrast, the increase of xylanase (Xyl) activity (especially in case of two species mixtures with birch) or its constant values compared to agricultural control plot were connected with high substrate inputs with the forest litter and fine roots (Supplementary materials) rich in hemicellulose. Activities of leucine aminopeptidase (LAP) decreased by afforestation for 1.5 - 6 times, whereas LAP affinity increased, showing the shift in microbial community to K-strategies with more efficient enzyme systems. Simultaneous development of oak or beech in two species mixtures with birch increased N-Acetyl- $\beta$-d-glucosaminidase (NAG) activity compared to other species, showing high $\mathrm{N}$ limitation in these soils and intensive decomposition of microbial polymers, such as chitine. In contrast, the presence of alder did not affect much LAP or NAG activities in two or three species mixtures, showing that $\mathrm{N}$-fixing trees supply microorganisms with sufficient available $\mathrm{N}$, even when growing in mixtures. High acid phosphatase activity was found under monocultural alder and birch forests, as well as under two species mixtures with birch, reflecting the same trend as for $\mathrm{N}$-acquisition enzymes. This shows the link between enzymes responsible for $\mathrm{N}$ and $\mathrm{P}$-cycling in young forest soils. Thus, microbial enzyme systems react differently to afforestation with species having contrast functional traits, even for enzymes responsible for one nutrient. The maximal activities between the forests were found for the sites, where birch developed simultaneously with late successional species, showing synergistic effects on soil microorganisms.

In addition to the changes in extracellular enzyme activities after afforestation, I studied the impact of afforestation with mono-, bi- and tri-species mixtures of alder, birch or beech on $\mathrm{N}$ cycling (chapter 6). There were no differences revealed in $\mathrm{N}$ functional gene abundance for the investigated plots. In contrast, differences in $\mathrm{N}$ cycling rates were found for the pure alder forests: namely, high gross and net nitrification rates were observed compared with the mixtures containing 
birch or beech. In addition, lower ammonification rates were found in the pure beech forest compared to pure birch. Thus, it is recommended that $\mathrm{N}$ functional gene abundance, transcript level and rates of $\mathrm{N}$ processes should all be taken into account when estimating the effect of afforestation with pure and mixed species cultures on $\mathrm{N}$ cycling in soils.

The direct product of polymer decomposition is monomers (LMWOS), which actually serve as a main $\mathrm{C}$ and $\mathrm{N}$ source for microorganisms and can be utilized directly. Although LMWOS have been intensively investigated in the last 20 years, a proper review of the current state of knowledge regarding sugars in soil, including their content, composition and fate, was lacking. In addition, there was a knowledge gap regarding the effect of substance physicochemical properties on their fate in soil. To address the first issue, a review on the content, composition and fate of carbohydrates in soil was performed and is presented in chapter 7. This review compiled and analyzed two databases. The first databases was focused on the content of total, non-cellulose, hotwater and cold-water extractable sugars in soils, as well as on the origin of sugars in forest, grassland and cropland soils. The second databases was dedicated to summarizing findings regarding ${ }^{13} \mathrm{C}$ and ${ }^{14} \mathrm{C}$ labelled sugars (mainly glucose) utilization by microorganisms with trace ${ }^{13} \mathrm{C} /{ }^{14} \mathrm{C}$ in three pools: mineralized $\left(\mathrm{CO}_{2}\right)$, incorporated into living microbial biomass (MB) and stabilized within the dead microbial residues. In addition, primary (plants derived) and secondary (recycled) sources of glucose $\mathrm{C}$ in soil were estimated and their mean residence times (MRT) were calculated.

It was revealed that glucose dominated the cellulose and non-cellulose sugars in soil due to its diverse origins, including plant and microbial residues and root and microbial excretions. For non-cellulose sugars, the ratio of hexoses to pentoses (applied to estimate the origin of sugars) revealed the highest values for forest soil (1.5), whereas for grassland and cropland it was 0.7 and 1.0, respectively (Gunina and Kuzyakov, 2015). The high ratio for forest soils was due to the presence of high amounts of hexoses in forest litter, especially in conifers, rather than high input of microbial residues. Thus, applying the hexose to pentose ratio to identify sugar origin requires analysis of the chemical composition of plant litter (Gunina and Kuzyakov, 2015).

Based on the amount of cellulose-derived glucose in soil and the assessed input of cellulose from plant biomass (using deciduous forest as an example), the MRT of cellulose was calculated to be $1.4 \mathrm{y}^{-1}$. Slow decomposition of plant polysaccharides continuously delivers sugars for microorganisms to maintain their metabolism and functions. The maximum initial decomposition rate of glucose, taken up from soil solution, was $1.1 \% \mathrm{~min}^{-1}$, whereas the MRT of glucose in MB 
was $34 \mathrm{~min}^{-1}$. Such rapid decomposition of glucose together with fast uptake from soil solution must be compensated by high sugar input. Based on the sugar content in dissolved organic matter and initial glucose $\mathrm{C}$ decomposition rate, the possible input of sugar $\mathrm{C}$ into soil solution was calculated to be $5 \mathrm{Mg} \mathrm{ha}^{-1}$ (using deciduous forest as an example ). The assessed input of total glucose $\mathrm{C}$ from plants (for deciduous forest) was $1 \mathrm{Mg} \mathrm{ha}^{-1}$. Thus, only $1 / 5$ of all available sugars in soil solution are from plant biomass and 4/5 are derived from recycling processes (Gunina and Kuzyakov, 2015).

Despite the high microbial demand for sugars, $\mathrm{C}$ from sugars is not mineralized to $\mathrm{CO}_{2}$ completely; part of it undergoes intensive internal recycling. The calculated MRT of sugar C in living MB was $230 \mathrm{~d}$. This comparatively long MRT of C in MB can be attributed to i) the intensive recycling of glucose $\mathrm{C}$ within the $\mathrm{MB}$ pool and ii) its incorporation into cell polymers.

Based on the dynamics of labeled glucose $\mathrm{C}$ in SOM and in $\mathrm{MB}$, the portion of sugar $\mathrm{C}$ in microbial residues was estimated. The distribution of sugar $\mathrm{C}$ in microbial residues showed a nearly constant value (18\% of applied tracer) during a $300 \mathrm{~d}$ period. This reflects the use of sugar $\mathrm{C}$ to produce polymer cell compounds that can be stabilized within the SOM. Thus, the contribution of sugar $\mathrm{C}$ to the total soil sugar $\mathrm{C}$ pool is higher than the traditionally estimated $10 \pm 5 \%$ and its importance for SOM formation is much higher than the actual amount of sugar $\mathrm{C}$ in the soil.

As was shown in chapter 7, the turnover of individual LMWOS in soil can be estimated by measuring the rate of $\mathrm{CO}_{2}$ evolution after substrate addition to soil. However, this approach fails to realistically capture the dynamics of LMWOS in soil. In chapter 8 , the uptake of three common classes of LMWOS (sugars, carboxylic and amino acids) from the soil solution and their subsequent mineralization by the soil microbial community were studied over a $24 \mathrm{~h}$ period. Rather than focus on substrate concentrations, the present study investigated the physicochemical properties of substances, including substance $\mathrm{C}$ oxidation state, number of $-\mathrm{COOH}$ groups and $\mathrm{C}$ atoms. The combined of use of ${ }^{14} \mathrm{C}$-labelled substrates at natural concentrations with repeated measurements over short timescales allowed estimation of actual rates of LMWOS loss from the soil solution, as well as mineralization rates of the initially applied $\mathrm{C}$.

The half-life of the LMWOS in soil solution ranged from 0.5 to $3.8 \mathrm{~min}$, with the shortest time observed for carboxylic acids and the longest for sugars (Gunina et al., 2017b). This suggests that microbial uptake of all classes of LMWOS from the solution is not a rate-limiting step in their utilization. The half-life $\left(T_{1 / 2}\right)$ of the LMWOS in solution decreased with $\mathrm{C}$ oxidation state. In contrast, the $T_{1 / 2}$ of LMWOS in soil solution increased with the number of $\mathrm{C}$ atoms, showing that 
larger molecules persist longer, possibly due to their slower rates of diffusion in soil. Thus, it may be possible to predict the uptake of common LMWOS by microorganisms from the soil solution based on the physicochemical properties of the substance .

The LMWOS-C half-life in the rapidly mineralizable pool $\left(T_{1 / 2-\text { fast }}\right)$, calculated by a double exponential model fitted to the portion of applied ${ }^{14} \mathrm{C}$-LMWOS in the SOC pool over time, ranged between 30 and 80 min and was the lowest for amino acids and highest for carboxylic acids. Large differences between LMWOS $T_{1 / 2}$ in solution and in soil shows that microbial uptake and subsequent mineralization of LMWOS are temporally decoupled. The $T_{1 / 2 \text {-fast }}$ of LMWOS-C in soil was not dependent on the properties of the substance, which implies that intercellular metabolism is the main factor determining initial mineralization of LMWOS-C.

The total portion of $\mathrm{C}$ mineralized from each class of LMWOS increased with the substance's C oxidation state, suggesting that oxidized compounds are mineralized to a greater degree than more reduced compounds. To support this observation, the LMWOS-C half-life in the slowly mineralizable pool $\left(T_{1 / 2-\text { slow }}\right)$ decreased as $\mathrm{C}$ oxidation state increased, while the portion of LMWOS-C incorporated into the cytosol and remaining in SOC decreased with each substance's C oxidation state. Thus, substance properties directly affected the final partitioning of LMWOS-C between mineralized and microbially-utilized pools.

\subsection{Conclusions}

In the present work, the structure and function of soil microbial communities in forest ecosystems were studied. The work clearly shows that microbial community structure and activity are regulated by a number of factors, namely: i) climatic conditions (abiotic factors), ii) composition of the plant community (biotic factors), iii) properties of organic compounds entering the soil. It was shown that abiotic factors (MAT and MAP) affect soil microbial community structure indirectly, mainly via modification of environmental conditions for microbial development (e.g. soil $\mathrm{pH}$ and $\mathrm{C}$ and $\mathrm{N}$ content) and plant community productivity. Thus, further research considered only biotic factors. The effect of biotic factors (forest composition) revealed that development of forest monocultures, even when composed of species with different functional traits (e.g. early primary $v s$ late successional species and $\mathrm{N}$-fixing $v s$ non-N-fixing), promotes formation of similar soil microbial communities. In contrast, the simultaneous presence of early primary and late successional species stimulates the development of different community compositions; however, this effect is declined in mixtures of two early primary and late successional species. Thus, species identity is more important that species diversity for the formation of soil microbial community structure in forests. 
The information about microbial community structure under various forests does not, however, provide insights into the function of microorganisms and regulation of elements cycling. Thus, to answer this question, the capacity of microorganisms to decompose organic polymers from litter and soil organic matter composition (SOM), was evaluated by estimating activity of extracellular enzymes responsible for $\mathrm{C}, \mathrm{N}$ and $\mathrm{P}$ cycling. It was found that enzyme systems of microorganisms react differently to afforestation with species having contrasting functional traits, even for enzymes responsible for one nutrient cycle. The maximum levels of enzyme activity for $\mathrm{N}$ Acetyl- $\beta$-d-glucosaminidase, xylanase and acid phosphatase were found for the sites where birch developed simultaneously with late successional species, showing synergistic effects. In contrast to that, forest diversity did not have an effect on activity of extracellular enzymes, showing that this parameter is also related more to species identity.

To take a closer look at the cycling of $\mathrm{N}$ in soils formed under various tree species (i.e. $\mathrm{N}$ fixing species grown in monoculture or in mixtures with non- $\mathrm{N}$-fixing species), the $\mathrm{N}$ functional gene abundance and $\mathrm{N}$ cycling rates were estimated. It was concluded that both parameters should be measured to made accurate conclusions about shifts in $\mathrm{N}$ processes after afforestation.

The activity of extracellular enzymes shows only the ability of microorganisms to breakdown organic polymers in plant litter compositio or in SOM; however, to make conclusion about utilization of organic compounds within microbial cells, a closer look at the decomposition of organic monomers (LMWOS, namely sugars, carboxylic acid and amino acid, which are the main components of the soil solution) is needed. Simple decomposition of LMWOS in soil under various vegetation types was intensively investigated before, and review studies have even been conducted on the fate of carboxylic (Jones, 1998) and amino acids (Jones et al., 2005) in soils. However, no detailed analysis of the composition, content and fate of sugars in soils existed previously, so the present study closed this knowledge gap. The important outcome of this review was that $1 / 5$ of sugars in the soil solution are derived from primary source (i.e. plant residues), whereas 4/5 are from recycling processes. This fact can partly explain the decrease of $\beta$-glucosidase activity with afforestation, observed in present study.

Further work was related to the ability of microorganisms to utilize various LMWOS classes in the soil solution. It is known that plant community composition affects the fate of organic monomers; however, intrinsic properties of LMWOS can also contribute significantly to utilization patterns. In the present research, it was shown that it may be possible to predict the uptake of common LMWOS by microorganisms from the soil solution based on the physiochemical 
properties of the substance, including $\mathrm{C}$ oxidation state and number of $\mathrm{C}$ atoms. In contrast, it was found that rates of LMWOS-C cycling within the microbial cells cannot be predicted based on these parameters; rather, intracellular metabolic cycles determine LMWOS-C fate in the ana- and catabolism processes. However, substance properties directly affect the final partitioning of LMWOS-C between mineralized and microbially-utilized pools.

Thus, biotic factors should be taken into account first when studying microbial community composition in forest soils, with the focus on trees species identity. In contrast to that, climatic factors effect indirectly to microbial community structure in forests, mainly via modificaion of soil properties. For the estimation of microorganism function in forest soils, molecular methods as well as direct measurements of processes rates should be performed. In addition to substance class, substance intrinsic properties can affect the fate of LMWOS in the soil, which can be used to predict the microbial utilization pattern of these substances in the forest as well as in other soils.

Present results can be used during afforestation and forest soil management, namely: i) for afforestation, species identity should be taken into account first, and not forest diversity, ii) for improvement of nutrient dynamics ( $\mathrm{N}$ and $\mathrm{P}$ ), mixtures of early primary successional species (birch or alder) should be planted with late successional species (oak or beech) in two species mixtures. For estimation of nutrient cycling in the young forests, the measurement of processes rates is more preferential, compared to molecular methods (gene abundance). Fot the estimation of microorganisms functioning, not only the subtance class, which microorganisms utilize for $\mathrm{C}$ and energy, should be taken into account, but also properties of the substances.

\subsection{Future research}

It was shown in chapter 3 that abiotic factors (i.e. MAP and MAT) can affect the structure of soil microbial communities. Future work should be related to a more detailed investigation of changes to soil microbial community structure with elevation, namely with the application of precise molecular techniques such as metagenomics. This will help to reveal the shift in particular groups of microorganisms with elevation.

Although a predominant effect of tree species identity vs diversity on the structure of microbial communities in young forest soils was revealed (chapter 4), more research is needed in this direction. Further studies should be focused on the several aspects, namely, i) soil microbial community structure in mature forests with various species (monoculture as well as mixed-species forests) should be compared and ii) the effect of the understory can be studied in managed forest 
experiments. Previous studies have shown that the proportion of a particular tree species (e.g. beech) in a mixed forests can have significant effects on the structure of soil microbial communities (Scheibe et al., 2015). Therefore, this impact needs to be proven for other tree species.

The functioning of microorganisms is the leading parameter regulating nutrients cycling in ecosystems. As was shown above, the activity of extracellular enzymes is very sensitive to land use change (chapter 5), and, thus, can be used to estimate the shifts in nutrient cycles after afforestation. The possible development of this topic is connected with the estimation of extracellular enzymatic activity in chronosequence forests, to reveal how kinetic parameters of enzyme function $\left(\mathrm{K}_{\mathrm{m}}\right.$ and $\mathrm{V}_{\max }$ ) change with the forest development. In addition, such studies can be done with various forest types, to reveal how the quality of litter inputs can affect $\mathrm{C}, \mathrm{N}$ and $\mathrm{P}$ cycling.

In the present work, the fate of LMWOS was studied with the main focus on their short-term decomposition and utilization by microorganisms (chapter 8). It is known that LMWOS-C is incorporated into cell metabolites during its utilization within the microbial biomass. Since the MB pool is highly dynamic in soil and has a rapid turnover time, microbial residues can account for more than $60 \%$ of SOM. If LMWOS are the main C and energy source for microorganisms and the final product of polymers decomposition, their contribution to SOM stabilization is actually underestimated. Thus, future research should be directed towards quantifying the portion of LMWOS-C which can be stabilized in SOM as microbial residues.

Previous research was mainly focused on the estimation of LMWOS mineralization or incorporation of LMWOS-C into microbial biomass. The main parameters considered were the type of substance or its concentration. In this study, I have shown that other LMWOS parameters, such as $\mathrm{C}$ oxidation state, can affect the fate of LMWOS in the soil. Future research directions are related to more precise study of how properties of LMWOS impact other important parameter of substances utilization, such as energy release from both cata- and anabolism. Since various LMWOS are incorporated into diverse metabolic cycles within microorganisms, differences in energy production from the utilization of various LMWOS classes can be expected. Properties of the substances within the substance classes likely also have an effect on the fate of LMWOS. 


\section{References (for chapters 1, 2 and 9)}

Adamczyk, B., Kilpeläinen, P., Kitunen, V., Smolander, A., 2014. Potential activities of enzymes involved in $\mathrm{N}, \mathrm{C}, \mathrm{P}$ and $\mathrm{S}$ cycling in boreal forest soil under different tree species. Pedobiologia 57, 97-102. doi:10.1016/j.pedobi.2013.12.003

Alriksson, A., Olsson, M.T., 1995. Soil changes in different age classes of Norway spruce (Picea abies (L.) Karst.) on afforested farmland. Plant Soil 168-169, 103-110. doi:10.1007/BF00029319

An, S., Mentler, A., Mayer, H., Blum, W.E.H., 2010. Soil aggregation, aggregate stability, organic carbon and nitrogen in different soil aggregate fractions under forest and shrub vegetation on the Loess Plateau, China. Catena 81, 226-233. doi:10.1016/j.catena.2010.04.002

Apostel, C., Dippold, M.A., Glaser, B., Kuzyakov, Y., 2013. Biochemical pathways of amino acids in soil. Soil Biol. Biochem. 67, 31-40.

Bandick, A.K., Dick, R.P., 1999. Field management effects on soil enzyme activities. Soil Biol. Biochem. 31, 1471-1479. doi:10.1016/S0038-0717(99)00051-6

Banning, N.C., Gleeson, D.B., Grigg, A.H., Grant, C.D., Andersen, G.L., Brodie, E.L., Murphy, D.V., 2011. Soil Microbial Community Successional Patterns during Forest Ecosystem Restoration $\nabla$. Appl. Environ. Microbiol. 77, 6158-6164. doi:10.1128/AEM.00764-11

Besnard, E., Chenu, C., Balesdent, J., Puget, P., Arrouays, D., 1996. Fate of particulate organic matter in soil aggregates during cultivation. Eur. J. Soil Sci. 47, 495-503. doi:10.1111/j.1365-2389.1996.tb01849.x

Blum, U., 1998. Effects of Microbial Utilization of Phenolic Acids and their Phenolic Acid Breakdown Products on Allelopathic Interactions. J. Chem. Ecol. 24, 685-708.

Boddy, E., Hill, P.W., Farrar, J., Jones, D.L., 2007. Fast turnover of low molecular weight components of the dissolved organic carbon pool of temperate grassland field soils. Soil Biol. Biochem. 39, 827-835. doi:10.1016/j.soilbio.2006.09.030

Boyle, S., A., Yarwood, R.R., Bottomley, P.J., Myrold, D.D., 2008. Bacterial and fungal contributions to soil nitrogen cycling under Douglas fir and red alder at two sites in Oregon. Soil Biol. Biochem. 40, 443-451.

Braker, G., Fesefeldt, A., Witzel, K.-P., 1998. Development of PCR Primer Systems for Amplification of Nitrite Reductase Genes (nirK and nirS) To Detect Denitrifying Bacteria in Environmental Samples. Appl. Environ. Microbiol. 64, 3769-3775.

Brant, J.B., Sulzman, E.W., Myrold, D.D., 2006. Microbial community utilization of added carbon substrates in response to long-term carbon input manipulation. Soil Biol. Biochem. 38, 2219-2232. doi:10.1016/j.soilbio.2006.01.022

Burns, R.G., DeForest, J.L., Marxsen, J., Sinsabaugh, R.L., Stromberger, M.E., Wallenstein, M.D., Weintraub, M.N., Zoppini, A., 2013. Soil enzymes in a changing environment: Current knowledge and future directions. Soil Biol. Biochem. 58, 216-234. doi:10.1016/j.soilbio.2012.11.009

Cavagnaro, T.R., Cunningham, S.C., Fitzpatrick, S., 2016. Pastures to woodlands: changes in soil microbial communities and carbon following reforestation. Appl. Soil Ecol. 107, 24-32. doi:10.1016/j.apsoil.2016.05.003

Das, S.K., Varma, A., 2010. Role of Enzymes in Maintaining Soil Health, in: Soil Enzymology, Soil Biology. Springer, Berlin, Heidelberg, pp. 25-42. doi:10.1007/978-3-642-14225-3_2

Degens, B.P., Harris, J.A., 1997. Development of a physiological approach to measuring the catabolic diversity of soil microbial communities. Soil Biol. Biochem. 29, 1309-1320. doi:10.1016/s0038-0717(97)00076-x 
DeLuca, T.H., Boisvenue, C., 2012. Boreal forest soil carbon: distribution,function and modelling. Forestry doi:10.1093/forestry/cps003.

Deng, Q., Cheng, X., Hui, D., Zhang, Q., Li, M., Zhang, Q., 2016. Soil microbial community and its interaction with soil carbon and nitrogen dynamics following afforestation in central China. Sci. Total Environ. 541, 230-237. doi:10.1016/j.scitotenv.2015.09.080

Dick, W.A., Cheng, L., Wang, P., 2000. Soil acid and alkaline phosphatase activity as pH adjustment indicators. Soil Biol. Biochem. 32, 1915-1919. doi:10.1016/S00380717(00)00166-8

Dixon, R.K., Brown, S., Houghton, R.A., Solomon, A.M., Trexler, M.C., Wisniewski, J., 1994. Carbon pools and fluxes of global forest ecosystems. Sci. Total Environ. 263, 185-190.

Dorodnikov, M., Blagodatskaya, E., Blagodatsky, S., Marhan, S., Fangmeier, A., Kuzyakov, Y., 2009. Stimulation of microbial extracellular enzyme activities by elevated $\mathrm{CO}(2)$ depends on soil aggregate size. Glob. Change Biol. 15, 1603-1614. doi:10.1111/j.13652486.2009.01844.x

Farrar, J., Hawes, M., Jones, D., Lindow, S., 2003. How roots control the flux of carbon to the rhizosphere. Ecology 84, 827-837. doi:10.1890/0012-9658(2003)084[0827:hrctfo]2.0.co;2

Fatemi, F.R., Fernandez, I.J., Simon, K.S., Dail, D.B., 2016. Nitrogen and phosphorus regulation of soil enzyme activities in acid forest soils. Soil Biol. Biochem. 98, 171-179. doi:10.1016/j.soilbio.2016.02.017

Fierer, N., Jackson, R.B., 2006. The diversity and biogeography of soil bacterial communities. Proc. Natl. Acad. Sci. U. S. A. 103, 626-631. doi:10.1073/pnas.0507535103

Finzi, A.C., Abramoff, R.Z., Spiller, K.S., Brzostek, E.R., Darby, B.A., Kramer, M.A., Phillips, R.P., 2015. Rhizosphere processes are quantitatively important components of terrestrial carbon and nutrient cycles. Glob. Change Biol. 21, 2082-2094. doi:10.1111/gcb.12816

Fischer, H., Kuzyakov, Y., 2010. Sorption, microbial uptake and decomposition of acetate in soil. Soil Biol. Biochem. 42, 186-192. doi:10.1016/j.soilbio.2009.10.015

Frostegard, A., Tunlid, A., Baath, E., 1991. Microbial biomass measured as total lipid phosphate in soils of different organic content. J. Microbiol. Methods 14, 151-163. doi:10.1016/01677012(91)90018-1

Fu, X., Yang, F., Wang, J., Di, Y., Dai, X., Zhang, X., H, W., 2015. Understory vegetation leads to changes in soil acidity and in microbial communities 27 years after reforestation. Sci. Total Environ. 502, 280-286.

Glanville, H., Rousk, J., Golyshin, P., Jones, D.L., 2012. Mineralization of low molecular weight carbon substrates in soil solution under laboratory and field conditions. Soil Biol. Biochem. 48, 88-95. doi:10.1016/j.soilbio.2012.01.015

Glanville, H.C., Hill, P.W., Schnepf, A., Oburger, E., Jones, D.L., 2016. Combined use of empirical data and mathematical modelling to better estimate the microbial turnover of isotopically labelled carbon substrates in soil. Soil Biol. Biochem. 94, 154-168. doi:10.1016/j.soilbio.2015.11.016

Grayston, S.J., Vaughan, D., Jones, D., 1997. Rhizosphere carbon flow in trees, in comparison with annual plants. Appl. Soil Ecol. 5, 29-56. doi:10.1016/s0929-1393(96)00126-6

Griffiths, B.S., Ritz, K., Ebblewhite, N., Dobson, G., 1999. Soil microbial community structure. Soil Biol. Biochem. 31, 145-153.

Grosso, F., Temussi, F., De Nicola, F., 2014. Water-extractable organic matter and enzyme activity in three forest soils of the Mediterranean area. Eur. J. Soil Biol. 64, 15-22. doi:10.1016/j.ejsobi.2014.06.003

Gunina, A., Dippold, M., Glaser, B., Kuzyakov, Y., 2014. Fate of low molecular weight organic substances in an arable soil. Soil Biol. Biochem. 77, 304-313. 
Gunina, A., Kuzyakov, Y., 2015. Sugars in soil and sweets for microorganisms. Soil Biol. Biochem. doi:10.1016/j.soilbio.2015.07.021.

Gunina, A., Smith, A.R., Godbold, D.L., Jones, D.L., Kuzyakov, Y., 2017a. Response of soil microbial community to afforestation with pure and mixed species. Plant Soil 412, 357-368. doi:10.1007/s11104-016-3073-0

Gunina, A., Smith, A.R., Kuzyakov, Y., Jones, D.L., 2017b. Microbial uptake and utilization of low molecular weight organic substrates in soil depend on carbon oxidation state. Biogeochemistry 133, 89-100. doi:10.1007/s10533-017-0313-1

Guo, X., Chen, H.Y.H., Meng, M., Biswas, S.R., Ye, L., Zhang, J., 2016. Effects of land use change on the composition of soil microbial communities in a managed subtropical forest. For. Ecol. Manag. 373, 93-99. doi:10.1016/j.foreco.2016.03.048

Hackl, E., Pfeffer, M., Donat, C., Bachmann, G., Zechmeister-Boltenstern, S., 2005. Composition of the microbial communities in the mineral soil under different types of natural forest. Soil Biol. Biochem. 37, 661-671.

Herbert, D.A., Williams, M., Rastetter, E.B., 2003. A model analysis of $\mathrm{N}$ and P limitation on carbon accumulation in Amazonian secondary forest after alternate land-use abandonment. Biogeochemistry 65, 121-150. doi:10.1023/A:1026020210887

Hill, P.W., Farrar, J.F., Jones, D.L., 2008. Decoupling of microbial glucose uptake and mineralization in soil. Soil Biol. Biochem. 40, 616-624. doi:10.1016/j.soilbio.2007.09.008

Hoogmoed, M., Cunningham, S.C., Baker, P., Beringer, J., Cavagnaro, T.R., 2014. N-fixing trees in restoration plantings: Effects on nitrogen supply and soil microbial communities. Soil Biol. Biochem. 77, 203-212. doi:10.1016/j.soilbio.2014.06.008

Johansson, M.-B., 1995. The chemical composition of needle and leaf litter from Scots pine, Norway spruce and white birch in Scandinavian forests. For. Int. J. For. Res. 68, 49-62. doi:10.1093/forestry/68.1.49

Jones, D.L., 1999. Amino acid biodegradation and its potential effects on organic nitrogen capture by plants. Soil Biol. Biochem. 31, 613-622. doi:10.1016/s0038-0717(98)00167-9

Jones, D.L., 1998. Organic acids in the rhizosphere - a critical review. Plant Soil 205, 25-44. doi:10.1023/a:1004356007312

Jones, D.L., Kemmitt, S.J., Wright, D., Cuttle, S.P., Bol, R., Edwards, A.C., 2005. Rapid intrinsic rates of amino acid biodegradation in soils are unaffected by agricultural management strategy. Soil Biol. Biochem. 37, 1267-1275. doi:10.1016/j.soilbio.2004.11.023

Kaiser, C., Fuchslueger, L., Koranda, M., Gorfer, M., Stange, C.F., Kitzler, B., Rasche, F., Strauss, J., Sessitsch, A., Zechmeister-Boltenstern, S., Richter, A., 2011. Plants control the seasonal dynamics of microbial $\mathrm{N}$ cycling in a beech forest soil by belowground $\mathrm{C}$ allocation. Ecology 92, 1036-1051.

Kaiser, C., Koranda, M., Kitzler, B., Fuchslueger, L., Schnecker, J., Schweiger, P., Rasche, F., Zechmeister-Boltenstern, S., Sessitsch, A., Richter, A., 2010. Belowground carbon allocation by trees drives seasonal patterns of extracellular enzyme activities by altering microbial community composition in a beech forest soil. New Phytol. 187, 843-858. doi:10.1111/j.1469-8137.2010.03321.x

Kalinina, O., Krause, S.E., Goryachkin, S.V., Karavaeva, N.A., Lyuri, D.I., Giani, L., 2011. Self restoration of post-agrogenic chernozems of Russia: soil development, carbon stocks, and dynamics of carbon pools. Geoderma 162, 196-206.

Koranda, M., Kaiser, C., Fuchslueger, L., Kitzler, B., Sessitsch, A., Zechmeister-Boltenstern, S., Richter, A., 2013. Seasonal variation in functional properties of microbial communities in beech forest soil. Soil Biol. Biochem. 60, 95-104. doi:10.1016/j.soilbio.2013.01.025 
Korkanç, S.Y., 2014. Effects of afforestation on soil organic carbon and other soil properties. CATENA 123, 62-69. doi:10.1016/j.catena.2014.07.009

Kujur, M., Kumar Patel, A., 2014. Kinetics of soil enzyme activities under different ecosystems: An index of soil quality. Chil. J. Agric. Res. 74, 96-104. doi:10.4067/S071858392014000100015

Lal, R., 2005. Forest soils and carbon sequestration. For. Ecol. Manag. 220, 242-258.

Lengeler, J.W., Drews, G., Schlegel, H.G., 1999. Biology of the prokaryotes. Georg Thieme Verl. 955.

Lima, A.M.N., Silva, I.R., Neves, J.C.L., Novais, R.F., Barros, N.F., Mendonça, E.S., Smyth, T.J., Moreira, M.S., Leite, F.P., 2006. Soil organic carbon dynamics following afforestation of degraded pastures with eucalyptus in southeastern Brazil. For. Ecol. Manag. 235, 219-231. doi:10.1016/j.foreco.2006.08.331

Monreal, C.M., McGill, W.B., 1985. Centrifugal extraction and determination of free amino acids in soil solutions by TLC using tritiated 1-fluoro-2,4-dinitrobenzene. Soil Biol. Biochem. 17, 533-539. doi:10.1016/0038-0717(85)90021-5

Mulvaney, R.L., 1996. Methods of Soil Analysis. Part 3 - Chemical Methods. Soil Science Society of America, Inc., Wisconsin, USA.

Palomo, L., Claassen, N., Jones, D.L., 2006. Differential mobilization of P in the maize rhizosphere by citric acid and potassium citrate. Soil Biol. Biochem. 38, 683-692. doi:10.1016/j.soilbio.2005.06.019

Razavi, B.S., Blagodatskaya, E., Kuzyakov, Y., 2016. Temperature selects for static soil enzyme systems to maintain high catalytic efficiency. Soil Biol. Biochem. 97, 15-22. doi:10.1016/j.soilbio.2016.02.018

Ren, C., Kang, D., Wu, J. ping, Zhao, F., Yang, G., Han, X., Feng, Y., Ren, G., 2016. Temporal variation in soil enzyme activities after afforestation in the Loess Plateau, China. Geoderma 282, 103-111. doi:10.1016/j.geoderma.2016.07.018

Ritter, E., Vesterdal, L., Gundersen, P., 2003. Changes in soil properties after afforestation of former intensively managed soils with oak and Norway spruce. Plant Soil 249, 319-330.

Romanyà, J., Cortina, J., Falloon, P., Coleman, K., Smith, P., 2000. Modelling changes in soil organic matter after planting fast-growing Pinus radiata on Mediterranean agricultural soils. Eur. J. Soil Sci. 51, 627-641. doi:10.1111/j.1365-2389.2000.00343.x

Ross, D.J., 1983. Invertase and amylase activities as influenced by clay minerals, soil-clay fractions and topsoils under grassland. Soil Biol. Biochem. 15, 287-293. doi:10.1016/00380717(83)90073-1

Ryan, P.R., Delhaize, E., Jones, D.L., 2001. Function and mechanism of organic anion exudation from plant roots. Annu. Rev. Plant Physiol. Plant Mol. Biol. 52, 527-560. doi:10.1146/annurev.arplant.52.1.527

Sanaullah, M., Blagodatskaya, E., Chabbi, A., Rumpel, C., Kuzyakov, Y., 2011. Drought effects on microbial biomass and enzyme activities in the rhizosphere of grasses depend on plant community composition. Appl. Soil Ecol. 48, 38-44. doi:10.1016/j.apsoil.2011.02.004

Scheibe, A., Steffens, C., Seven, J., Jacob, A., Hertel, D., Leuschner, C., Gleixner, G., 2015. Effects of tree identity dominate over tree diversity on the soil microbial community structure. Soil Biol. Biochem. 81, 219-227.

Schimel, J., Schaeffer, S.M., 2012. Microbial control over carbon cycling in soil. Front. Microbiol. 3. doi:10.3389/fmicb.2012.00348

Schneckenberger, K., Demin, D., Stahr, K., Kuzyakov, Y., 2008. Microbial utilization and mineralization of $(14) \mathrm{C}$ glucose added in six orders of concentration to soil. Soil Biol. Biochem. 40, 1981-1988. doi:10.1016/j.soilbio.2008.02.020 
Singh, D., Lee-Cruz, L., Kim, W.-S., Kerfahi, D., Chun, J.-H., Adams, J.M., 2014. Strong elevational trends in soil bacterial community composition on Mt. Halla, South Korea. Soil Biol. Biochem. 68, 140-149. doi:10.1016/j.soilbio.2013.09.027

Strobel, B.W., 2001. Influence of vegetation on low-molecular-weight carboxylic acids in soil solution - a review. Geoderma 99, 169-198. doi:10.1016/s0016-7061(00)00102-6

Tedersoo, L., Bahram, M., Põlme, S., Kõljalg, U., Yorou, N.S., Wijesundera, R., Villarreal Ruiz, L., Vasco-Palacios, A.M., Thu, P.Q., Suija, A., Smith, M.E., Sharp, C., Saluveer, E., Saitta, A., Rosas, M., Riit, T., Ratkowsky, D., Pritsch, K., Põldmaa, K., Piepenbring, M., Phosri, C., Peterson, M., Parts, K., Pärtel, K., Otsing, E., Nouhra, E., Njouonkou, A.L., Nilsson, R.H., Morgado, L.N., Mayor, J., May, T.W., Majuakim, L., Lodge, D.J., Lee, S.S., Larsson, K.-H., Kohout, P., Hosaka, K., Hiiesalu, I., Henkel, T.W., Harend, H., Guo, L., Greslebin, A., Grelet, G., Geml, J., Gates, G., Dunstan, W., Dunk, C., Drenkhan, R., Dearnaley, J., De Kesel, A., Dang, T., Chen, X., Buegger, F., Brearley, F.Q., Bonito, G., Anslan, S., Abell, S., Abarenkov, K., 2014. Fungal biogeography. Global diversity and geography of soil fungi. Science 346, 1256688. doi:10.1126/science. 1256688

Tischer, A., Blagodatskaya, E., Hamer, U., 2015. Microbial community structure and resource availability drive the catalytic efficiency of soil enzymes under land-use change conditions. Soil Biol. Biochem. 89, 226-237. doi:10.1016/j.soilbio.2015.07.011

Vance, E.D., Brookes, P.C., Jenkinson, D.S., 1987. An extraction method for measuring soil microbial biomass C. Soil Biol. Biochem. 19, 703-707. doi:10.1016/0038-0717(87)90052-6

Vivanco, L., Austin, A.T., 2008. Tree species identity alters forest litter decomposition through long-term plant and soil interactions in Patagonia, Argentina. J. Ecol. 96, 727-736. doi:10.1111/j.1365-2745.2008.01393.x

Xu, M., Li, X., Cai, X., Gai, J., Li, X., Christie, P., Zhang, J., 2014. Soil microbial community structure and activity along a montane elevational gradient on the Tibetan Plateau. Eur. J. Soil Biol. 64, 6-14. doi:10.1016/j.ejsobi.2014.06.002

Xu, Z., Yu, G., Zhang, X., He, N., Wang, Q., Wang, S., Wang, R., Zhao, N., Jia, Y., Wang, C., 2017. Soil enzyme activity and stoichiometry in forest ecosystems along the North-South Transect in eastern China (NSTEC). Soil Biol. Biochem. 104, 152-163. doi:10.1016/j.soilbio.2016.10.020

Yang, Q., Lei, A.P., Li, F.L., Liu, L.N., Zan, Q.J., Shin, P.K.S., Cheung, S.G., Tam, N.F.Y., 2014. Structure and function of soil microbial community in artificially planted Sonneratia apetala and S. caseolaris forests at different stand ages in Shenzhen Bay, China. Mar. Pollut. Bull. 85, 754-763. doi:10.1016/j.marpolbul.2014.02.024

Zhang, Q., Yang, J., Koide, R.T., Li, T., Yang, H., Chu, J., 2017. A meta-analysis of soil microbial biomass levels from established tree plantations over various land uses, climates and plant communities. CATENA 150, 256-260. doi:10.1016/j.catena.2016.11.028 


\section{Appendix}

\section{Supplementary materials to Chapter 3}
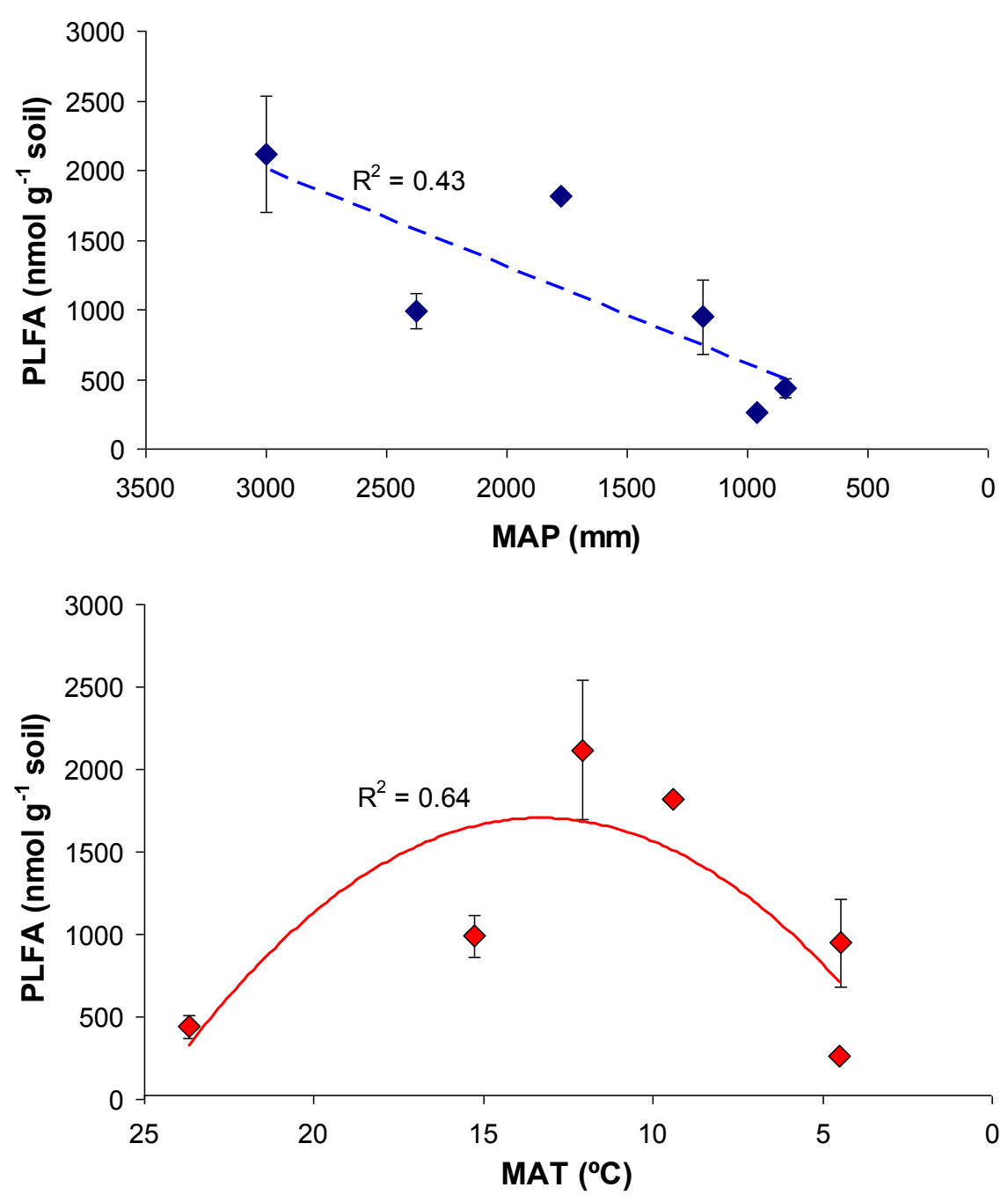

Supplementary figure 3-1. Changes of microbial biomarkers content calculated based on PLFAs analysis (in nmol $\mathrm{g}^{-1}$ soil) with mean annual precipitation (MAP) (top) and mean annual temperature (MAT) (bottom) for the $3500 \mathrm{~m}$ elevation gradient for the Mt Kilimanjaro. 

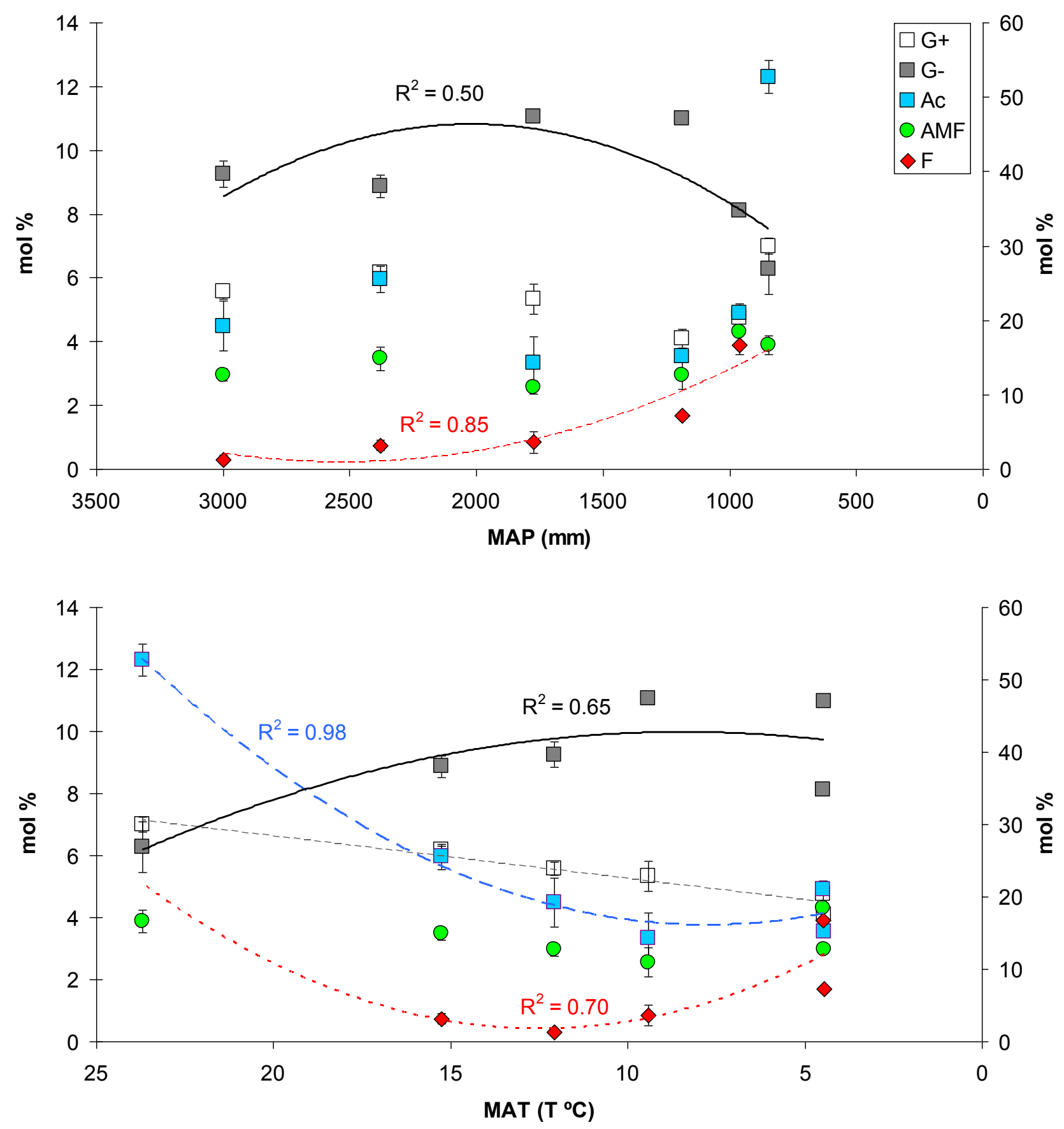

Supplementary figure 3-2. Changes of microbial biomarkers portions calculated based on PLFAs analysis (in mol \%) with mean annual temperature (MAT) and mean annual precipitation (MAP) for the 3500 m elevation gradient for the Mt Kilimanjaro. G+ is for gram-positive PLFAs, G- is Ac is gram-negative PLFAs, Ac is for actinomycetes, AMF is for Arbuscular mycorrhizal fungi, F is for fungi. 

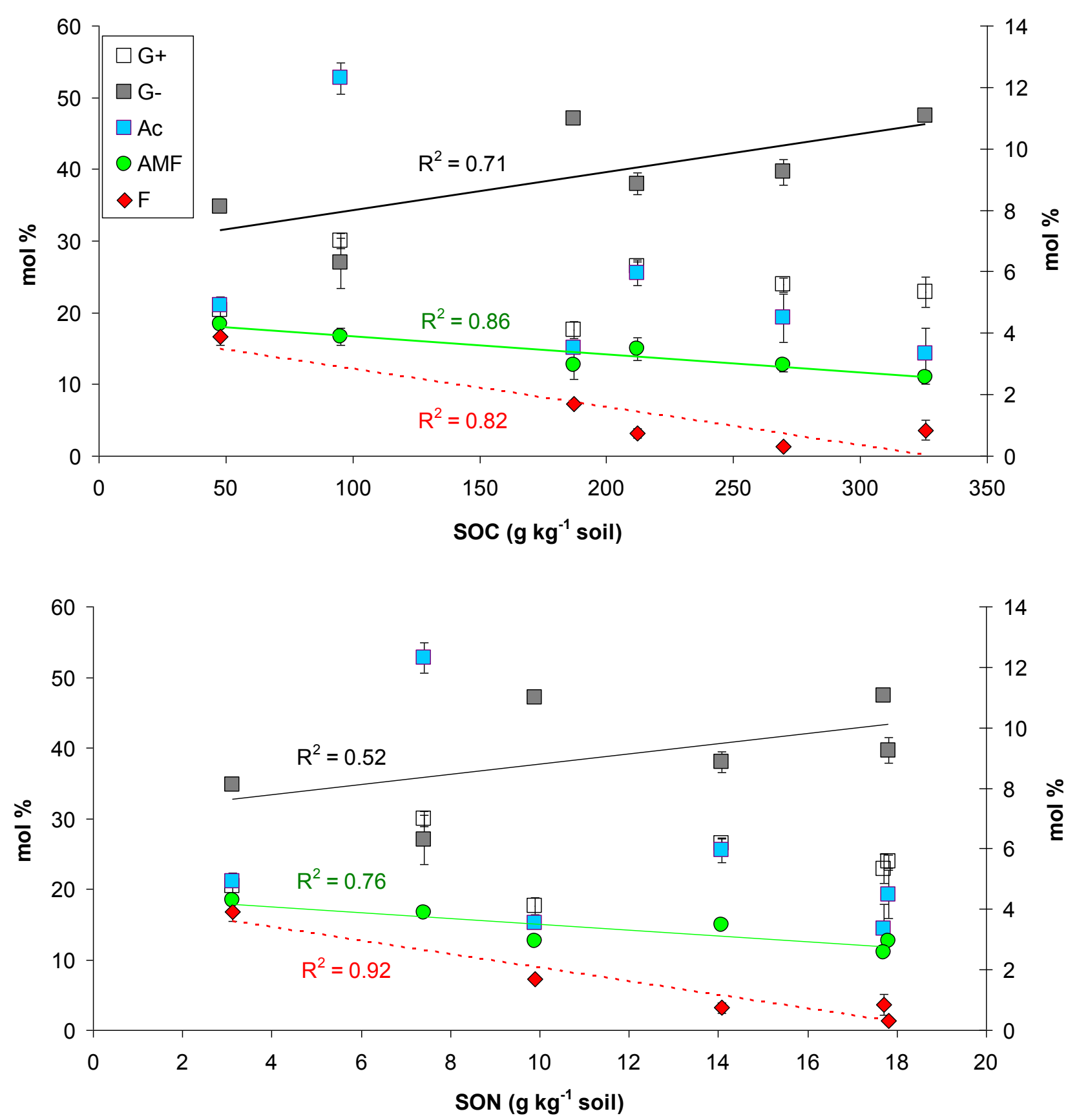

Supplementary figure 3-3. Changes of microbial biomarkers portions calculated based on PLFAs analysis (in mol \%) with soil C (top) and $\mathrm{N}$ (bottom) contents for the $3500 \mathrm{~m}$ elevation gradient for the Mt Kilimanjaro. G+ is for gram-positive PLFAs, G- is Ac is gram-negative PLFAs, Ac is for actinomycetes, AMF is for Arbuscular mycorrhizal fungi, $\mathrm{F}$ is for fungi. 


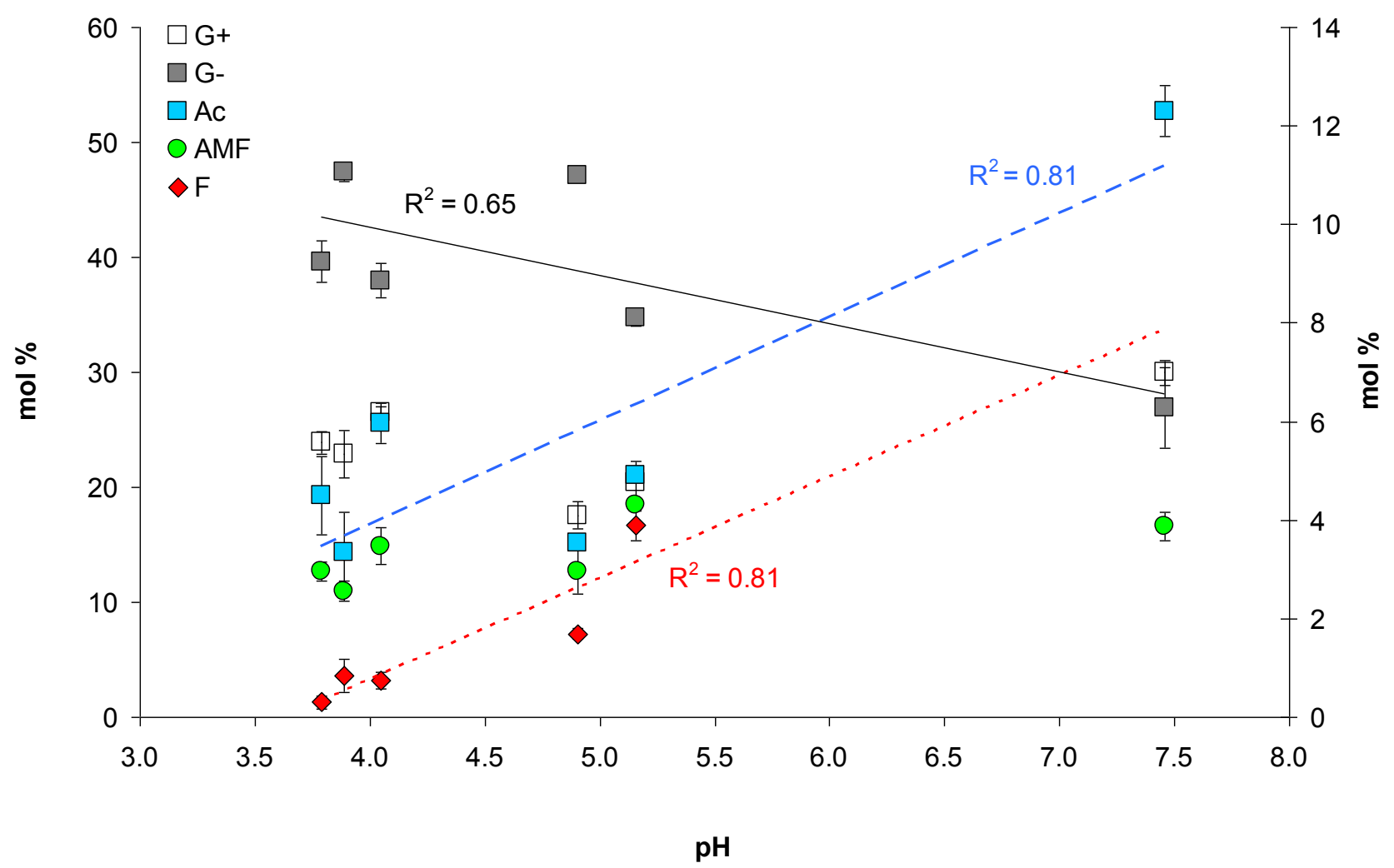

Supplementary figure 3-4. Changes of microbial biomarkers portions calculated based on PLFAs analysis (in mol \%) with soil $\mathrm{pH}$ values for the $3500 \mathrm{~m}$ elevation gradient for the Mt. Kilimanjaro. 


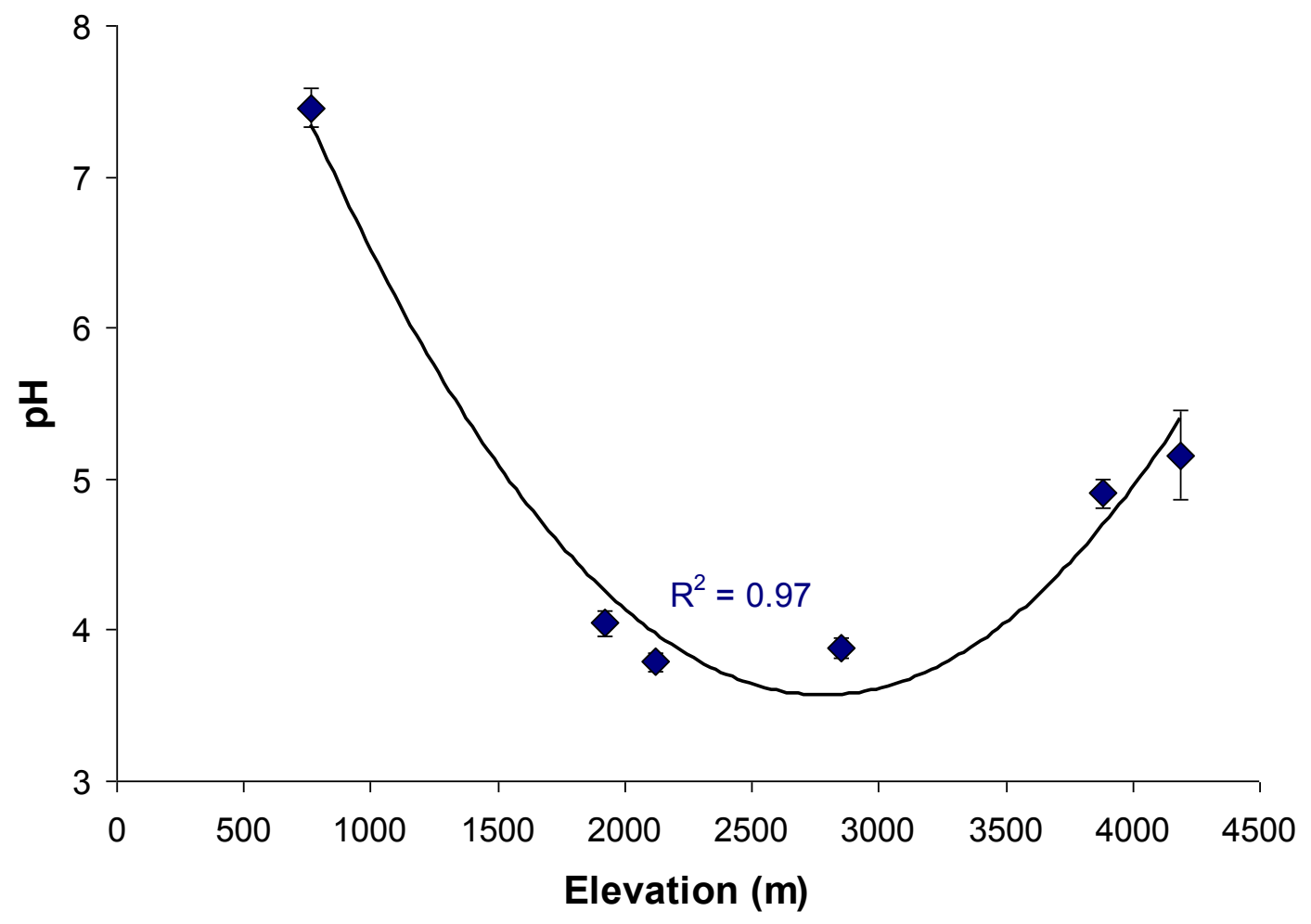

Supplementary figure 3-5. Changes of soil $\mathrm{pH}$ values within $3500 \mathrm{~m}$ elevation gradient on the Mt. Kilimanjaro. 


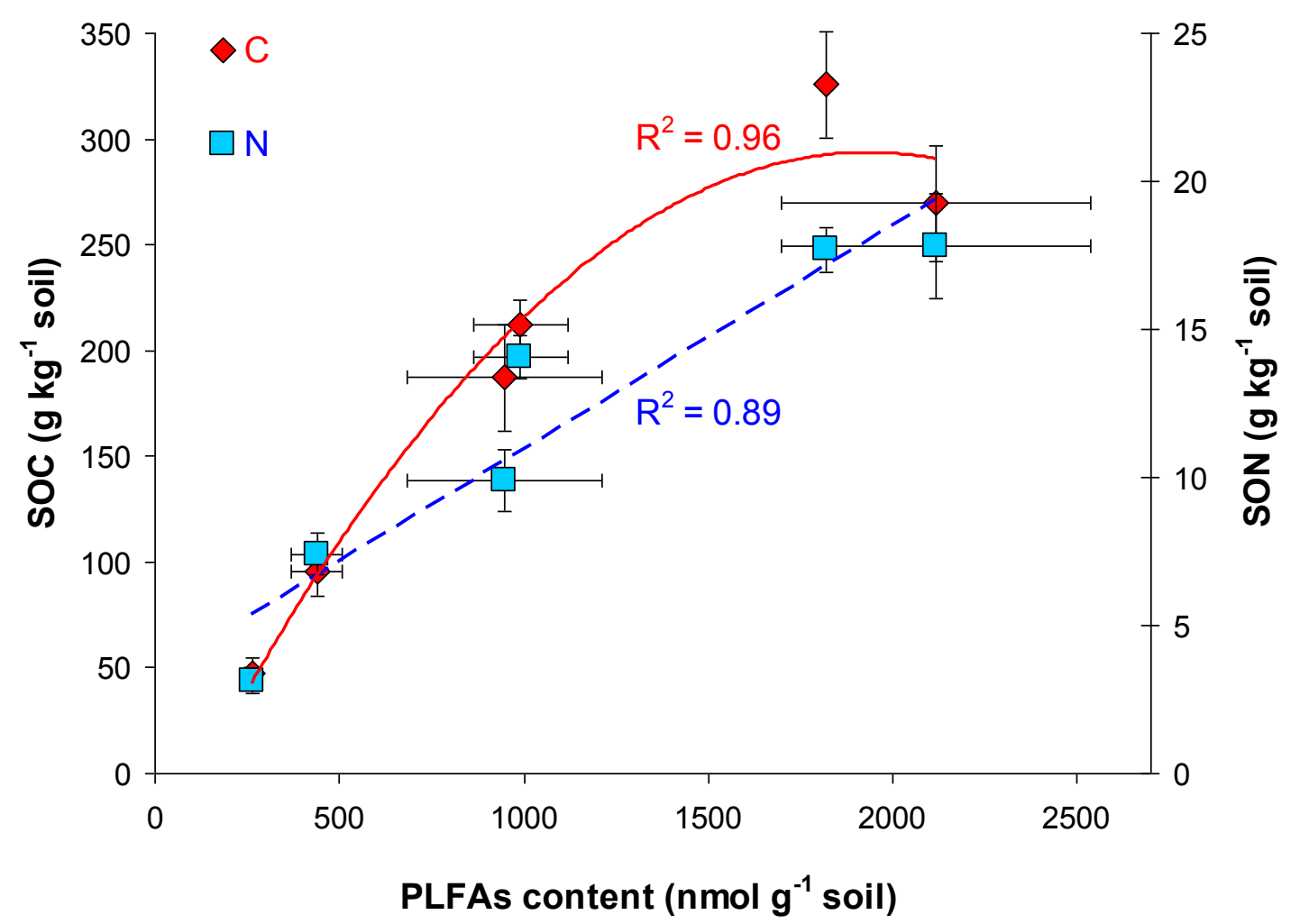

Supplementary figure 3-6. Changes of microbial biomarkers content with soil $\mathrm{C}$ and $\mathrm{N}$ contents for the $3500 \mathrm{~m}$ elevation gradient for the Mt Kilimanjaro. 


\section{Supplementary materials to Chapter 4}

Supplementary table 4-1. Relative abundance of PLFAs in soils under the different forest treatments and the agricultural control plots (mol\% of total PLFA) and total PLFAs content (nmol g ${ }^{-1}$ soil). Data present mean \pm st.error, $n=4$. Forest treatments: $\mathrm{Al}$ (alder), Bi (birch), $\mathrm{Be}$ (beech), Oa (oak), ABe (alder+beech), AOa (alder+oak), BiBe (birch+beech), BiOa (birch+oak), ABiBe (alder+birch+beech), ABiOa (alder+birch+oak). n.a. - data not available due to content was lower than detection limit of measurement.

\begin{tabular}{|c|c|c|c|c|c|c|c|c|c|c|c|}
\hline \multirow[t]{2}{*}{ PLFAs } & \multicolumn{2}{|c|}{ Primary forests } & \multicolumn{2}{|c|}{ Secondary forests } & \multicolumn{4}{|c|}{ Two species mixtures } & \multicolumn{2}{|c|}{ Three species mixtures } & \multirow{2}{*}{$\begin{array}{l}\text { Agricultural } \\
\text { Agro } \\
\end{array}$} \\
\hline & Oak & Beech & Birch & Alder & Birch+Oak & Birch+Beech & Alder+Oak & Alder+Beech & $\begin{array}{l}\text { Alder+Birch } \\
+ \text { Oak }\end{array}$ & $\begin{array}{l}\text { Alder+Birch+ } \\
\text { Beech }\end{array}$ & \\
\hline i14:0 & $0.89 \pm 0.13$ & $1.04 \pm 0.12$ & $2.15 \pm 0.15$ & $1.61 \pm 0.21$ & $1.62 \pm 0.10$ & $1.19 \pm 0.09$ & $1.50 \pm 0.06$ & $1.60 \pm 0.35$ & $1.22 \pm 0.12$ & $1.34 \pm 0.16$ & $3.17 \pm 0.07$ \\
\hline a14:0 & n.a & n.a & $0.49 \pm 0.00$ & n.a & n.a & n.a & n.a & n.a & n.a & n.a & n.a \\
\hline 14:0 & $0.43 \pm 0.08$ & $0.19 \pm 0.03$ & $1.56 \pm 0.06$ & $0.55 \pm 0.12$ & $2.25 \pm 0.04$ & $0.41 \pm 0.13$ & $2.49 \pm 0.05$ & $2.42 \pm 0.06$ & $0.61 \pm 0.07$ & $0.40 \pm 0.11$ & $2.07 \pm 0.11$ \\
\hline i15:0 & $10.98 \pm 0.73$ & $10.66 \pm 0.48$ & $8.82 \pm 0.29$ & $10.62 \pm 0.08$ & $8.92 \pm 0.11$ & $9.36 \pm 0.51$ & $9.61 \pm 0.41$ & $9.62 \pm 0.51$ & $9.74 \pm 0.35$ & $9.40 \pm 0.35$ & $8.22 \pm 0.21$ \\
\hline a15:0 & $6.46 \pm 0.30$ & $7.12 \pm 0.26$ & $8.24 \pm 0.26$ & $7.88 \pm 0.43$ & $8.14 \pm 0.12$ & $7.62 \pm 0.31$ & $7.58 \pm 0.35$ & $8.08 \pm 0.48$ & $8.34 \pm 0.64$ & $7.44 \pm 0.42$ & $7.85 \pm 0.16$ \\
\hline $15: 0$ & n.a & n.a & $0.41 \pm 0.02$ & n.a & $1.46 \pm 0.04$ & $0.24 \pm 0.00$ & $1.47 \pm 0.01$ & $1.42 \pm 0.04$ & n.a & n.a & $0.60 \pm 0.06$ \\
\hline i16:0 & $2.21 \pm 0.11$ & $2.04 \pm 0.17$ & $2.56 \pm 0.08$ & $2.22 \pm 0.14$ & $3.69 \pm 0.13$ & $2.37 \pm 0.24$ & $3.81 \pm 0.14$ & $3.64 \pm 0.03$ & $2.20 \pm 0.19$ & $2.19 \pm 0.14$ & $3.04 \pm 0.05$ \\
\hline $16: 1 w 7 c$ & $7.45 \pm 0.33$ & $7.23 \pm 0.08$ & $6.82 \pm 0.12$ & $7.43 \pm 0.18$ & $7.17 \pm 0.2$ & $6.87 \pm 0.27$ & $7.04 \pm 0.22$ & $7.53 \pm 0.25$ & $6.92 \pm 0.23$ & $6.87 \pm 0.05$ & $9.17 \pm 0.16$ \\
\hline $16: 1 w 5 c$ & $4.60 \pm 0.41$ & $4.18 \pm 0.36$ & $4.7 \pm 0.09$ & $4.42 \pm 0.18$ & $5.10 \pm 0.23$ & $3.95 \pm 0.26$ & $4.69 \pm 0.3$ & $4.55 \pm 0.23$ & $3.88 \pm 0.33$ & $4.19 \pm 0.31$ & $5.12 \pm 0.18$ \\
\hline $16: 0$ & $19.27 \pm 0.54$ & $18.91 \pm 0.75$ & $15.58 \pm 0.38$ & $18.15 \pm 0.35$ & $15.98 \pm 0.36$ & $18.01 \pm 0.23$ & $16.34 \pm 0.18$ & $16.07 \pm 0.19$ & $17.07 \pm 0.3$ & $16.78 \pm 0.44$ & $16.74 \pm 0.1$ \\
\hline 10Me16:0 & $1.55 \pm 0.11$ & $1.74 \pm 0.13$ & $1.72 \pm 0.16$ & $1.61 \pm 0.17$ & $3.07 \pm 0.09$ & $1.48 \pm 0.23$ & $3.30 \pm 0.18$ & $3.62 \pm 0.05$ & $1.72 \pm 0.12$ & $1.67 \pm 0.12$ & $2.11 \pm 0.11$ \\
\hline i17:0 & $2.62 \pm 0.18$ & $2.47 \pm 0.09$ & $2.45 \pm 0.03$ & $2.47 \pm 0.02$ & $1.45 \pm 0.07$ & $2.36 \pm 0.08$ & $2.05 \pm 0.12$ & $1.87 \pm 0.27$ & $2.68 \pm 0.06$ & $2.51 \pm 0.12$ & $2.67 \pm 0.09$ \\
\hline a17:0 & $0.5 \pm 0.05$ & $0.41 \pm 0.03$ & $0.49 \pm 0.06$ & $0.55 \pm 0.04$ & n.a & $0.55 \pm 0.1$ & n.a & n.a & $0.64 \pm 0.05$ & $0.65 \pm 0.06$ & $0.60 \pm 0.06$ \\
\hline cy17:0 & $3.60 \pm 0.14$ & $4.21 \pm 0.23$ & $3.59 \pm 0.14$ & $2.91 \pm 0.09$ & $0.56 \pm 0.32$ & $2.84 \pm 0.39$ & $2.13 \pm 0.31$ & $1.37 \pm 1.1$ & $2.64 \pm 0.17$ & $2.85 \pm 0.18$ & $4.01 \pm 0.17$ \\
\hline $17: 0$ & $0.02 \pm 0.00$ & n.a & $0.34 \pm 0.03$ & n.a & n.a & $0.12 \pm 0.1$ & n.a & n.a & n.a & $0.09 \pm$ n.a & $0.57 \pm 0.03$ \\
\hline $18: 2 w 6,9$ & $3.12 \pm 0.39$ & $2.94 \pm 0.21$ & $3.69 \pm 0.2$ & $2.52 \pm 0.35$ & $4.06 \pm 0.21$ & $4.34 \pm 0.69$ & $3.39 \pm 0.08$ & $3.83 \pm 0.00$ & $3.22 \pm 0.51$ & $3.81 \pm 0.56$ & $1.84 \pm 0.08$ \\
\hline $18: 1 w 9 c$ & $7.04 \pm 0.18$ & $6.86 \pm 0.11$ & $6.83 \pm 0.15$ & $7.05 \pm 0.18$ & $7.03 \pm 0.27$ & $8.23 \pm 0.9$ & $6.98 \pm 0.07$ & $7.18 \pm 0.12$ & $7.20 \pm 0.2$ & $7.56 \pm 0.17$ & $6.19 \pm 0.18$ \\
\hline $18: 1 w 7 c$ & $15.86 \pm 0.75$ & $15.70 \pm 0.59$ & $15.85 \pm 0.18$ & $16.33 \pm 0.32$ & $13.96 \pm 0.33$ & $16.35 \pm 0.6$ & $13.47 \pm 0.21$ & $14.52 \pm 0.97$ & $16.16 \pm 0.62$ & $17.05 \pm 0.19$ & $14.09 \pm 0.42$ \\
\hline $18: 0$ & $3.85 \pm 0.32$ & $4.12 \pm 0.19$ & $3.51 \pm 0.09$ & $4.05 \pm 0.15$ & $4.14 \pm 0.03$ & $3.76 \pm 0.23$ & $4.76 \pm 0.34$ & $4.13 \pm 0.19$ & $3.67 \pm 0.15$ & $3.62 \pm 0.1$ & $4.02 \pm 0.08$ \\
\hline 10Me18:0 & $0.83 \pm 0.11$ & $0.84 \pm 0.09$ & $1.26 \pm 0.09$ & $0.90 \pm 0.11$ & $2.04 \pm 0.14$ & $1.15 \pm 0.11$ & $1.96 \pm 0.09$ & $2.02 \pm 0.04$ & $1.37 \pm 0.11$ & $1.18 \pm 0.11$ & $1.97 \pm 0.07$ \\
\hline cy19:0 & $8.6 \pm 0.23$ & $9.28 \pm 0.42$ & $8.97 \pm 0.25$ & $8.72 \pm 0.42$ & $9.50 \pm 0.32$ & $9.60 \pm 0.46$ & $9.63 \pm 0.19$ & $10.01 \pm 0.68$ & $10.05 \pm 0.46$ & $10.4 \pm 0.54$ & $5.47 \pm 0.23$ \\
\hline $20: 4 w 6 c$ & n.a & n.a & n.a & n.a & n.a & $0.43 \pm 0.00$ & n.a & n.a & n.a & n.a & n.a \\
\hline $20: 1 w 9 c$ & $0.10 \pm 0.03$ & $0.09 \pm 0.03$ & $0.33 \pm 0.01$ & $0.02 \pm 0.01$ & n.a & $0.06 \pm 0.03$ & n.a & n.a & $0.05 \pm 0.02$ & $0.06 \pm 0.02$ & $0.47 \pm 0.02$ \\
\hline $20: 0$ & $0.10 \pm 0.00$ & n.a & n.a & n.a & n.a & n.a & n.a & n.a & $0.04 \pm 0.00$ & n.a & n.a \\
\hline
\end{tabular}


Supplementary table 4-2. Chemical properties of soils under the different forest treatments and the agricultural control plot. Data present mean \pm st. error, $n=4$. Letters present significant differences $(P<0.05)$ level between the treatments for each parameter separately. Significant differences were obtained by Fischer post hoc test.

\begin{tabular}{|c|c|c|c|c|c|c|c|c|c|}
\hline Plant type & Abbreviation & $\mathrm{pH}$ & $\mathrm{C}$ ( $\mathrm{g} \mathrm{kg}^{-1}$ soil) & $\mathrm{N}$ (g kg ${ }^{-1}$ soil) & $\mathrm{C}\left(\mathrm{t} \mathrm{ha}^{-1}\right)$ & $N\left(t_{h a}^{-1}\right)$ & $\mathrm{C} / \mathrm{N}$ & $\mathrm{NO}_{3}\left(\mathrm{mg} \mathrm{kg}^{-1}\right.$ soil) & $\mathrm{NH}_{4}\left(\mathrm{mg} \mathrm{kg}^{-1}\right.$ soil) \\
\hline Agricultural & Agr & $6.49(0.06)^{d}$ & $28.9 \pm 0.7^{c d}$ & $3.0(0.1)^{\mathrm{abc}}$ & $34.7 \pm 0.9^{\mathrm{a}}$ & $3.6 \pm 0.1^{a}$ & $9.65(0.30)^{d}$ & $2.84(0.10)^{\mathrm{ab}}$ & $0.013(0.006)^{\mathrm{abc}}$ \\
\hline Oak & Oak & $5.26(0.18)^{b c}$ & $27.3 \pm 0.7^{\mathrm{cd}}$ & $2.9(0.03)^{b c}$ & $25.1 \pm 0.7^{\mathrm{C}}$ & $2.6 \pm 0.03^{d}$ & $9.86(0.32)^{\mathrm{cd}}$ & $3.09(0.42)^{\mathrm{a}}$ & $0.025(0.009)^{\mathrm{abc}}$ \\
\hline Beech & $\mathrm{Be}$ & $5.23(0.06)^{\mathrm{ab}}$ & $24.8 \pm 1.3^{d}$ & $2.5(0.2)^{c}$ & $26.7 \pm 1.4^{\mathrm{bc}}$ & $2.7 \pm 0.2^{\mathrm{bcd}}$ & $9.52(0.12)^{\mathrm{cd}}$ & $1.51(0.25)^{\mathrm{c}}$ & $0.013(0.004)^{\mathrm{abc}}$ \\
\hline Birch & $\mathrm{Bi}$ & $5.36(0.03)^{b c}$ & $33.8 \pm 2.1^{\mathrm{ab}}$ & $3.2(0.3)^{\mathrm{abc}}$ & $30.4 \pm 1.9^{\mathrm{ab}}$ & $2.9 \pm 0.2^{\mathrm{bcd}}$ & $10.58(0.31)^{\mathrm{a}}$ & $1.50(0.07)^{c}$ & $0.012(0.003)^{\mathrm{bc}}$ \\
\hline Alder & $\mathrm{Al}$ & $5.29(0.05)^{\mathrm{bc}}$ & $29.97 \pm 0.9^{\mathrm{abcd}}$ & $3.1(0.1)^{\mathrm{abc}}$ & $31.2 \pm 0.9^{\mathrm{ab}}$ & $3.2 \pm 0.1^{\mathrm{abc}}$ & $9.620 .10)^{\mathrm{bcd}}$ & $2.47(0.08)^{\mathrm{abc}}$ & $0.020(0.001)^{b}$ \\
\hline Birch+Oak & $\mathrm{Bi}+\mathrm{Oak}$ & $5.47(0.08)^{c}$ & $29.9 \pm 2.0^{\mathrm{abcd}}$ & $3.0(0.2)^{\mathrm{abc}}$ & $26.9 \pm 1.8^{b c}$ & $2.7 \pm 0.2^{\mathrm{bcd}}$ & $10.01(0.04)^{\mathrm{abcd}}$ & $1.43(0.31)^{c}$ & $0.009(0.002)^{c}$ \\
\hline Birch+Beech & $\mathrm{Bi}+\mathrm{Be}$ & $5.38(0.07)^{\mathrm{bc}}$ & $34.7 \pm 1.8^{\mathrm{ab}}$ & $3.2(0.2)^{\mathrm{ab}}$ & $33.9 \pm 1.7^{\mathrm{a}}$ & $3.2 \pm 0.2^{\mathrm{ab}}$ & $10.50(0.06)^{\mathrm{ab}}$ & $1.43(0.17)^{c}$ & $0.009(0.002)^{c}$ \\
\hline Alder+Oak & $\mathrm{Al}+\mathrm{Oak}$ & $5.05(0.05)^{a}$ & $35.0 \pm 2.0^{\mathrm{a}}$ & $3.5(0.04)^{a}$ & $25.9 \pm 1.5^{\mathrm{bc}}$ & $2.6 \pm 0.02^{\mathrm{cd}}$ & $10.11(0.36)^{\mathrm{ab}}$ & $3.56(0.52)^{a}$ & $0.028(0.001)^{\mathrm{a}}$ \\
\hline Alder+Beech & $\mathrm{Al}+\mathrm{Be}$ & $5.35(0.18)^{b c}$ & $31.5 \pm 2.0^{\mathrm{abc}}$ & $3.1(0.2)^{\mathrm{abc}}$ & $30.3 \pm 1.9^{\mathrm{abc}}$ & $2.9 \pm 0.2^{\mathrm{bcd}}$ & $10.30(0.27)^{\mathrm{ab}}$ & $2.57(0.23)^{\mathrm{abc}}$ & $0.008(0.001)^{c}$ \\
\hline Alder+Birch+Oak & $\mathrm{Al}+\mathrm{Bi}+\mathrm{Oak}$ & $5.33(0.04)^{\mathrm{bc}}$ & $31.0 \pm 0.7^{\mathrm{bc}}$ & $3.0(0.1)^{\mathrm{abc}}$ & $28.6 \pm 0.6^{b c}$ & $2.8 \pm 0.1^{c d}$ & $10.23(0.25)^{\mathrm{abc}}$ & $1.83(0.22)^{\mathrm{bc}}$ & $0.01(0.001)^{c}$ \\
\hline Alder+Birch+Beech & $\mathrm{Al}+\mathrm{Bi}+\mathrm{Be}$ & $5.40(0.08)^{c}$ & $28.56 \pm 1.45^{\mathrm{cd}}$ & $3.1(0.2)^{\mathrm{ab}}$ & $28.2 \pm 1.5^{\mathrm{bc}}$ & $3.0 \pm 0.2^{\mathrm{ab}}$ & $9.56(0.20)^{d}$ & $2.53(0.06)^{\mathrm{abc}}$ & $0.01(0.003)^{c}$ \\
\hline
\end{tabular}




\section{Supplementary materials to Chapter 6}

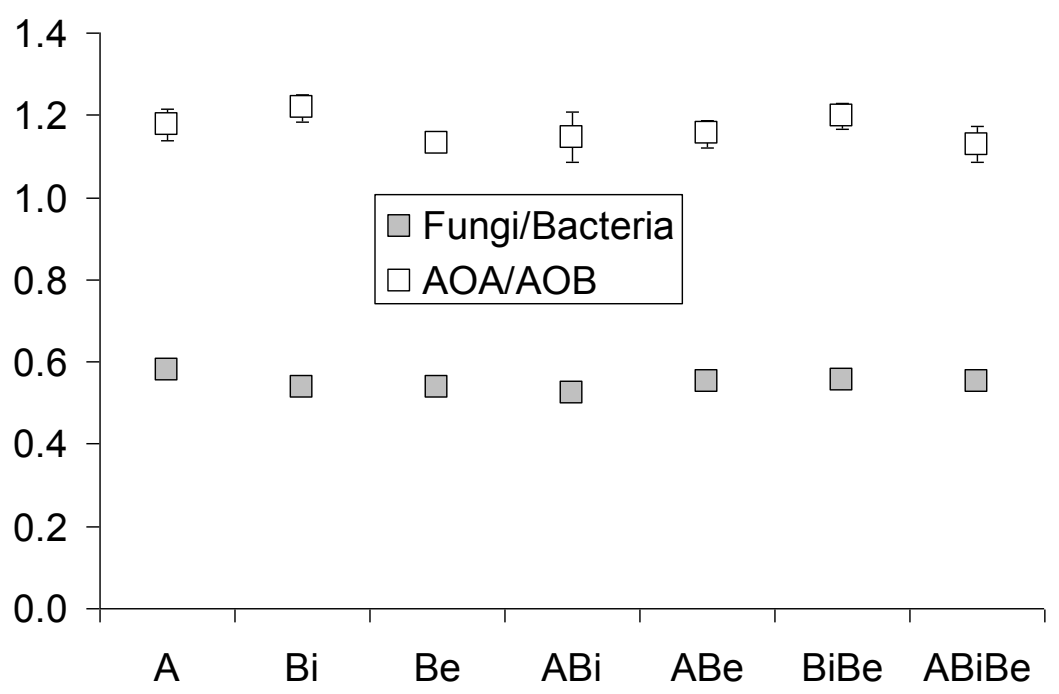

Supplementary figure 6-1. Ratios of fungi:bacteria and ammonia-oxidizing archaea to bacteria (AOA/AOB) gene copies compared across the 7 forest treatments. Values represent means $\pm \mathrm{SE}$ ( $n$ = 4). Al - alder, Bi - birch, Be - beech, AlBi - alder+birch, AlBe - alder+beech, AlBiBe alder+birch+beech. 
Supplementary Table 6-1. Soil properties among the 7 forest treatments (means $\pm \mathrm{SD}, n=4$ ). Letters reflect significant differences between forest types, $\mathrm{p}<0.05$. Al - alder, Bi - birch, Be beech, AlBi - alder+birch, AlBe - alder+beech, AlBiBe - alder+birch+beech.

\begin{tabular}{lccccc}
\hline & $\begin{array}{l}\text { Total C } \\
\left(\mathrm{g} \mathrm{kg}^{-1} \text { soil }\right)\end{array}$ & $\begin{array}{l}\text { Total N } \\
\left(\mathrm{g} \mathrm{kg}^{-1} \text { soil) }\right.\end{array}$ & $\mathrm{pH}$ & $\begin{array}{l}\mathrm{NH}_{4}{ }^{+} \\
\left(\mu \mathrm{g} \mathrm{g}^{-1} \text { soil }\right)\end{array}$ & $\begin{array}{l}\mathrm{NO}_{3}{ }^{-} \\
\left(\mu \mathrm{g} \mathrm{g}^{-1} \text { soil }\right)\end{array}$ \\
\hline Alder & $29.97(0.89)^{\mathrm{ab}}$ & $3.11(0.08)^{\mathrm{a}}$ & $5.29(0.05)^{\mathrm{a}}$ & $2.49(0.57)$ & $19.06(1.66)^{\mathrm{ab}}$ \\
Birch & $33.75(2.05)^{\mathrm{a}}$ & $3.21(0.26)^{\mathrm{a}}$ & $5.36(0.03)^{\mathrm{a}}$ & $4.01(0.60)$ & $16.19(1.13)^{\mathrm{ab}}$ \\
Beech & $24.78(1.33)^{\mathrm{b}}$ & $2.53(0.18)^{\mathrm{b}}$ & $5.23(0.06)^{\mathrm{a}}$ & $5.73(3.36)$ & $14.83(1.25)^{\mathrm{ab}}$ \\
Alder + Birch & $32.90(1.95)^{\mathrm{a}}$ & $3.13(0.12)^{\mathrm{a}}$ & $4.65(0.10)^{\mathrm{b}}$ & $4.10(0.61)$ & $15.94(4.67)^{\mathrm{b}}$ \\
Alder + Beech & $31.54(1.98)^{\mathrm{a}}$ & $3.06(0.15)^{\mathrm{ab}}$ & $5.35(0.18)^{\mathrm{a}}$ & $3.05(0.49)$ & $21.37(2.21)^{\mathrm{a}}$ \\
Birch + Beech & $34.65(1.77)^{\mathrm{a}}$ & $3.23(0.20)^{\mathrm{a}}$ & $5.38(0.07)^{\mathrm{a}}$ & $2.91(0.40)$ & $13.87(1.86)^{\mathrm{b}}$ \\
Alder + Birch + Beech & $30.02(1.79)^{\mathrm{a}}$ & $3.07(0.15)^{\mathrm{a}}$ & $5.40(0.08)^{\mathrm{a}}$ & $3.39(0.34)$ & $15.39(1.28)^{\mathrm{ab}}$ \\
\hline
\end{tabular}




\section{Supplementary materials to Chapter 7}
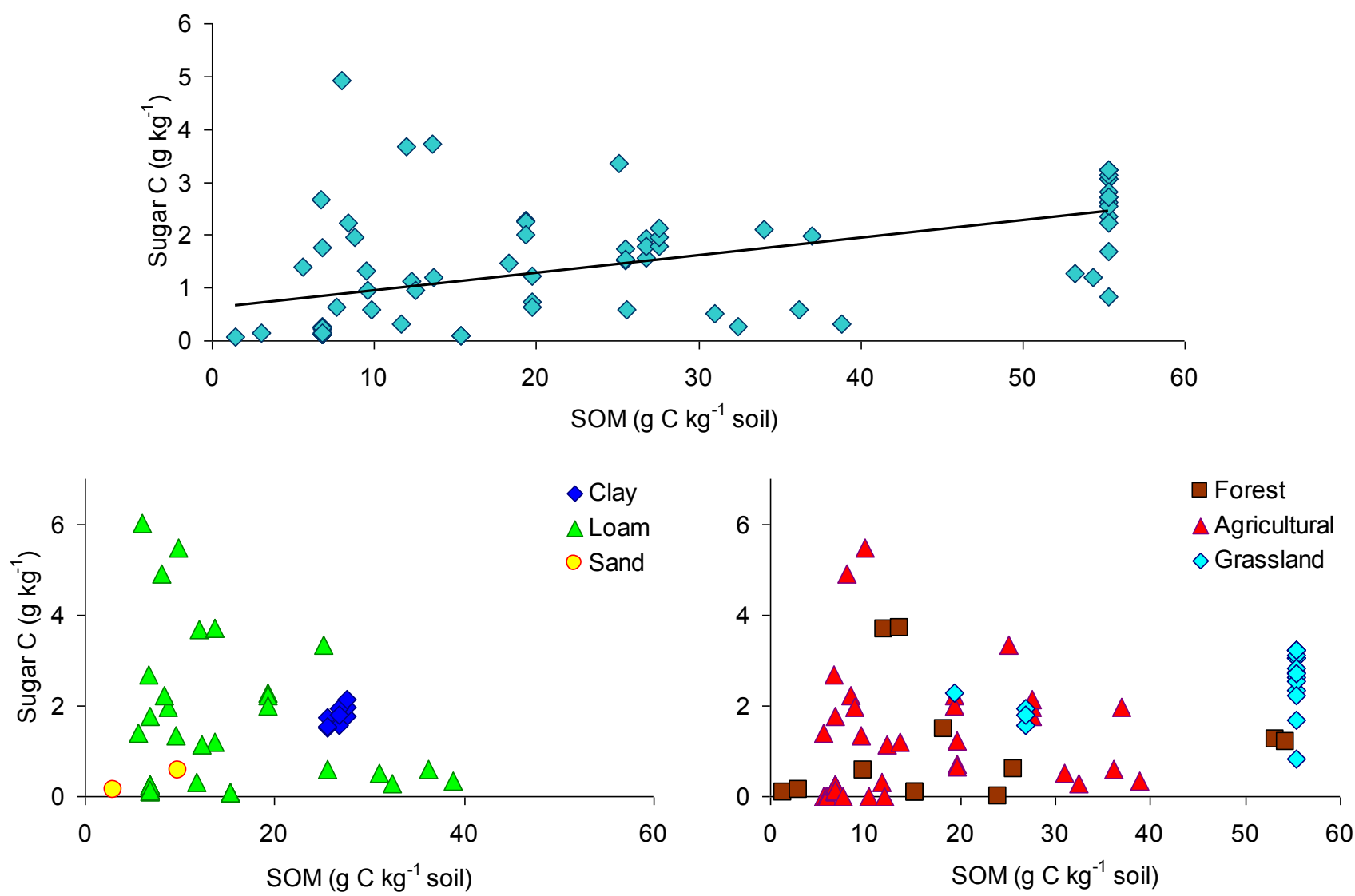

Supplementary figure 7-1. Non-cellulose sugar C content depending on: SOM (top), soil texture (bottom left), plant functional types (bottom right). Left and right bottom graphs are created with the same data, but left graph accounts only soil textures and right graph accounts only plant functional types. 
References Supplementary.

Supplementary figure 7-1.

Coniferous species: Pine (Ibrahima et al., 1995; Salamanca et al., 2003; Sariyildiz and Anderson, 2005; Zhang et al., 2014), Spruce (Albrechtova et al., 2008), Fir (Albrechtova et al., 2008; Sariyildiz and Anderson, 2005), Tamarack (Palosuo et al., 2005), Western red cedar (Palosuo et al., 2005); Deciduous species: Alder (Domenach et al., 1994), Beech (Sariyildiz and Anderson, 2003, 2005), Birch (Palosuo et al., 2005), Chestnut (Sariyildiz and Anderson, 2005), Maple (Salamanca et al., 2003), Oak (Ibrahima et al., 1995; Salamanca et al., 2003; Sariyildiz and Anderson, 2005; Sariyildiz et al., 2005), Poplar (Zhang et al., 2014), Willow (Zhang et al., 2014), Sea-buckthorn (Domenach et al., 1994), Trembling aspen (Palosuo et al., 2005); Herbs Rockrose (Ibrahima et al., 1995), Canola (Martens and Loeffelmann, 2002), Egyptian crowfoot grass (Mtambanengwe and Kirchmann, 1995), Clover (Martens and Loeffelmann, 2002), Alfalfa (Martens and Loeffelmann, 2002), Soybeans (Martens and Loeffelmann, 2002); Grasses: Oat (Martens and Loeffelmann, 2002), Prairie (Martens and Loeffelmann, 2002), Fescue (Palosuo et al., 2005), Highlander (Zhang et al., 2014); Legumes: Soybean (Martens and Loeffelmann, 2002), Alfalfa (Martens and Loeffelmann, 2002), Clover (Martens and Loeffelmann, 2002).

Supplementary figure 7-2

(Dalal and Henry, 1988; Hu et al., 1995; Jolivet et al., 2006; LarreLarrouy and Feller, 1997;

Martens and Loeffelmann, 2002)

Supplementary figure 7-3.

(Amelung et al., 1996; Angers and Mehuys, 1990; Baldock et al., 1987; Ball et al., 1996;

Benzingpurdie, 1980; Dalal and Henry, 1988; Derrien et al., 2007; Hu et al., 1995; Jolivet et al., 2006; LarreLarrouy and Feller, 1997; Martens and Loeffelmann, 2002; Murata et al., 1999; Oades and Wagner, 1970; Puget et al., 1999; Rumpel et al., 2010; Tanaka et al., 1990; Whitehead et al., 1975; Zhang et al., 2007)

Supplementary figure 7-4.

(Angers and Mehuys, 1990; Baldock et al., 1987; Ball et al., 1996; Benzingpurdie, 1980; Bock et al., 2007; Dalal and Henry, 1988; Derrien et al., 2007; Fischer et al., 2007; Hu et al., 1995; Jolivet et al., 2006; LarreLarrouy and Feller, 1997; Martens and Loeffelmann, 2002; Murata et al., 1999; Puget et al., 1999; Rumpel et al., 2010; Tanaka et al., 1990; Whitehead et al., 1975; Zhang et al., 2007)

Supplementary figure 7-5.

(Angers and Mehuys, 1990; Baldock et al., 1987; Ball et al., 1996; Benzingpurdie, 1980; Bock et al., 2007; Murata et al., 1999; Murayama, 1981; Nierop et al., 2001; Puget et al., 1999; Rumpel et al., 2010; Sariyildiz and Anderson, 2003, 2005; Schaedel et al., 2010; Zhang et al., 2007)

Supplementary figure 7-7.

(Boddy et al., 2007; Bremer and Vankessel, 1990; Coody et al., 1986; Hill et al., 2008; Jones and Murphy, 2007; Nguyen and Guckert, 2001) 
Supplementary figure 7-8.

Supplementary Fig. 7-8. (Amato and Ladd, 1992; Bardgett and Saggar, 1994; Bastida et al., 2013; Boddy et al., 2007; Bremer and Kuikman, 1994; Bremer and Vankessel, 1990; Chander and Brookes, 1991; Chander and Joergensen, 2001; Chotte et al., 1998; Coody et al., 1986; Gregorich et al., 1991; Ladd et al., 1992; Ladd et al., 1996;; Nguyen and Guckert, 2001; Oades and Wagner, 1970; Perelo and Munch, 2005;; Schneckenberger et al., 2008; Vanveen et al., 1985; Witter and Dahlin, 1995;)

Albrechtova, J., Seidl, Z., Aitkenhead-Peterson, J., Lhotakova, Z., Rock, B.N., Alexander, J.E., Malenovsky, Z., McDowell, W.H., 2008. Spectral analysis of coniferous foliage and possible links to soil chemistry: Are spectral chlorophyll indices related to forest floor dissolved organic $\mathrm{C}$ and $\mathrm{N}$ ? Science of the Total Environment 404, 424-432.

Amelung, W., Cheshire, M.V., Guggenberger, G., 1996. Determination of neutral and acidic sugars in soil by capillary gas-liquid chromatography after trifluoroacetic acid hydrolysis. Soil Biology \& Biochemistry 28, 1631-1639.

Angers, D.A., Mehuys, G.R., 1990. Barley and alfalfa cropping effects on carbohydrate contents of a clay soil and its size fractions. Soil Biology \& Biochemistry 22, 285-288.

Baldock, J.A., Kay, B.D., Schnitzer, M., 1987. Influence of cropping treatments on the monosaccharide content of the hydrolysates of a soil and its aggregate fractions. Canadian Journal of Soil Science 67, 489-499.

Ball, B.C., Cheshire, M.V., Robertson, E.A.G., Hunter, E.A., 1996. Carbohydrate composition in relation to structural stability, compactibility and plasticity of two soils in a long-term experiment. Soil \& Tillage Research 39, 143-160.

Benzingpurdie, L., 1980. Organic matter and carbohydrate distribution in an Orthic Humic Gleysol. Soil Biology \& Biochemistry 12, 567-571.

Bock, M., Glaser, B., Millar, N., 2007. Sequestration and turnover of plant- and microbially derived sugars in a temperate grassland soil during 7 years exposed to elevated atmospheric $\mathrm{pCO}(2)$. Global Change Biology 13, 478-490.

Boddy, E., Hill, P.W., Farrar, J., Jones, D.L., 2007. Fast turnover of low molecular weight components of the dissolved organic carbon pool of temperate grassland field soils. Soil Biology \& Biochemistry 39, 827-835.

Bremer, E., Vankessel, C., 1990. Extractability of microbial C-14 and N-15 following addition of variable rates of labeled glucose and $\left(\mathrm{NH}_{4}\right)_{2} \mathrm{SO}_{4}$ to soil. Soil Biology \& Biochemistry 22, 707-713. Coody, P.N., Sommers, L.E., Nelson, D.W., 1986. kinetics of glucose uptake by soil microorganisms. Soil Biology \& Biochemistry 18, 283-289.

Dalal, R.C., Henry, R.J., 1988. Cultivation effects on carbohydrate contents of soil and soil fractions. Soil Science Society of America Journal 52, 1361-1365.

Derrien, D., Marol, C., Balesdent, J., 2007. Microbial biosyntheses of individual neutral sugars among sets of substrates and soils. Geoderma 139, 190-198.

Domenach, A.M., Moiroud, A., Jocteurmonrozier, L., 1994. Leaf carbon and nitrogen constituents of some actinorhizal tree species. Soil Biology \& Biochemistry 26, 649-653.

Fischer, H., Meyer, A., Fischer, K., Kuzyakov, Y., 2007. Carbohydrate and amino acid composition of dissolved organic matter leached from soil. Soil Biology \& Biochemistry 39, 2926-2935.

Hill, P.W., Farrar, J.F., Jones, D.L., 2008. Decoupling of microbial glucose uptake and mineralization in soil. Soil Biology \& Biochemistry 40, 616-624. 
Hu, S., Coleman, D.C., Hendrix, P.F., Beare, M.H., 1995. Biotic manipulation effects on soil carbohydrates and microbial biomass in a cultivated soil. Soil Biology \& Biochemistry 27, 11271135.

Ibrahima, A., Joffre, R., Gillon, D., 1995. Changes in litter during the initial leaching phase: An experiment on the leaf litter of Mediterranean species. Soil Biology \& Biochemistry 27, 931-939. Jolivet, C., Angers, D.A., Chantigny, M.H., Andreux, F., Arrouays, D., 2006. Carbohydrate dynamics in particle-size fractions of sandy spodosols following forest conversion to maize cropping. Soil Biology \& Biochemistry 38, 2834-2842.

Jones, D.L., Murphy, D.V., 2007. Microbial response time to sugar and amino acid additions to soil. Soil Biology \& Biochemistry 39, 2178-2182.

LarreLarrouy, M.C., Feller, C., 1997. Determination of carbohydrates in two ferrallitic soils: Analysis by capillary gas chromatography after derivatization by silylation. Soil Biology \& Biochemistry 29, 1585-1589.

Martens, D.A., Loeffelmann, K.L., 2002. Improved accounting of carbohydrate carbon from plants and soils. Soil Biology \& Biochemistry 34, 1393-1399.

Mtambanengwe, F., Kirchmann, H., 1995. Litter from a tropical savanna woodland (miombo):

Chemical composition and C and N mineralization. Soil Biology \& Biochemistry 27, 1639-1651.

Murata, T., Tanaka, H., Yasue, S., Hamada, R., Sakagami, K., Kurokawa, Y., 1999. Seasonal variations in soil microbial biomass content and soil neutral sugar composition in grassland in the Japanese Temperate Zone. Applied Soil Ecology 11, 253-259.

Murayama, S., 1981. Persistency and monosaccharide composition of polysaccharides of soil which received no plant materials for a certain period under field conditions. Soil Science and Plant Nutrition 27, 463-475.

Nguyen, C., Guckert, A., 2001. Short-term utilisation of C-14- U glucose by soil microorganisms in relation to carbon availability. Soil Biology \& Biochemistry 33, 53-60.

Nierop, K.G.J., van Lagen, B., Buurman, P., 2001. Composition of plant tissues and soil organic matter in the first stages of a vegetation succession. Geoderma 100, 1-24.

Oades, J.M., Wagner, G.H., 1970. Incorporation of ${ }^{14} \mathrm{C}$ into sugars in a soil incubated with ${ }^{14} \mathrm{C}$ glucose. Geoderma 4, 417-\&.

Palosuo, T., Liski, J., Trofymow, J.A., Titus, B.D., 2005. Litter decomposition affected by climate and litter quality - Testing the Yasso model with litterbag data from the Canadian intersite decomposition experiment. Ecological Modelling 189, 183-198.

Puget, P., Angers, D.A., Chenu, C., 1999. Nature of carbohydrates associated with water-stable aggregates of two cultivated soils. Soil Biology \& Biochemistry 31, 55-63.

Rumpel, C., Eusterhues, K., Koegel-Knabner, I., 2010. Non-cellulosic neutral sugar contribution to mineral associated organic matter in top- and subsoil horizons of two acid forest soils. Soil Biology \& Biochemistry 42, 379-382.

Salamanca, E.F., Kaneko, N., Katagiri, S., 2003. Rainfall manipulation effects on litter decomposition and the microbial biomass of the forest floor. Applied Soil Ecology 22, 271-281. Sariyildiz, T., Anderson, J.M., 2003. Interactions between litter quality, decomposition and soil fertility: a laboratory study. Soil Biology \& Biochemistry 35, 391-399.

Sariyildiz, T., Anderson, J.M., 2005. Variation in the chemical composition of green leaves and leaf litters from three deciduous tree species growing on different soil types. Forest Ecology and Management 210, 303-319.

Schaedel, C., Boechl, A., Richter, A., Hoch, G., 2010. Quantification and monosaccharide composition of hemicelluloses from different plant functional types. Plant Physiology and Biochemistry 48, 1-8. 
Tanaka, H., Hamada, R., Kondoh, A., Sakagami, K., 1990. Determination of component sugars in soil organic matter by HPLC. Zentralblatt Fur Mikrobiologie 145, 621-628.

Whitehead, D.C., Buchan, H., Hartley, R.D., 1975. Components of soil organic matter under grass and arable cropping. Soil Biology \& Biochemistry 7, 65-71.

Zhang, C.-B., Chen, L.-H., Jiang, J., 2014. Why fine tree roots are stronger than thicker roots: The role of cellulose and lignin in relation to slope stability. Geomorphology 206, 196-202.

Zhang, W., He, H., Zhang, X., 2007. Determination of neutral sugars in soil by capillary gas chromatography after derivatization to aldononitrile acetates. Soil Biology \& Biochemistry 39, 2665-2669. 


\section{Supplementary materials to Chapter 8}

\section{Table 8-1}

\section{Supplementary tables}

Supplementary table 8-1. Physicochemical properties of the studied LMWOS.

\begin{tabular}{|c|c|c|c|}
\hline Substance & $\begin{array}{l}\text { C oxidation } \\
\text { state }\end{array}$ & $\begin{array}{l}\text { Number of } \\
\text { C atoms }\end{array}$ & $\begin{array}{l}\text { Number of } \\
-\mathrm{COOH} \text { groups }\end{array}$ \\
\hline Glucose & 0 & 6 & 0 \\
\hline Fructose & 0 & 6 & 0 \\
\hline Formic acid & +2 & 1 & 1 \\
\hline Malic acid & +1 & 4 & 2 \\
\hline Succinic acid & +0.5 & 4 & 2 \\
\hline Alanine & 0 & 3 & 1 \\
\hline Glycine & +1 & 2 & 1 \\
\hline
\end{tabular}


Figure 8-1.

Supplementary figures

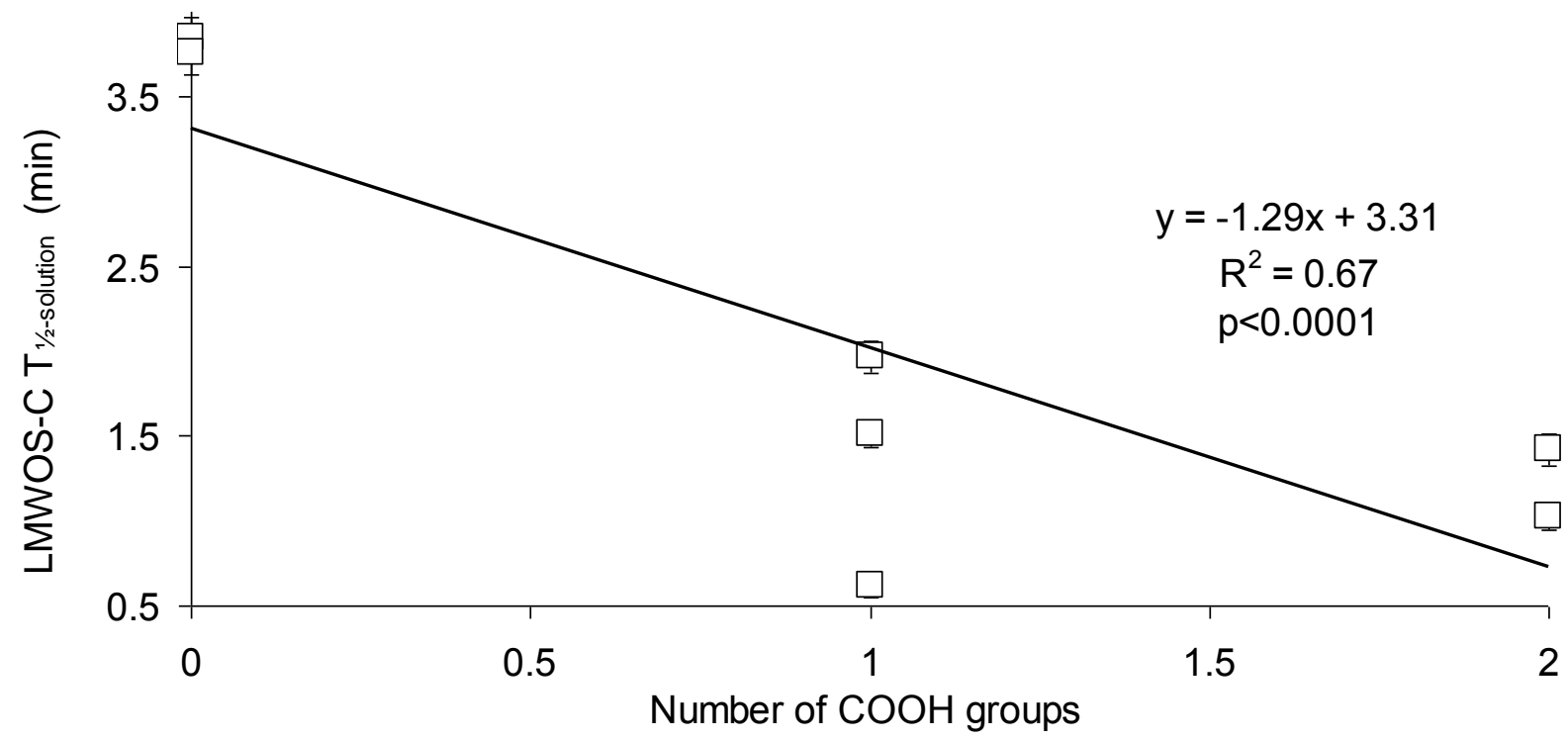

Supplementary figure 8-1. Relationship between the half-life (min) of different LMWOS in soil solution and number of $-\mathrm{COOH}$ groups. Values represent means $\pm \operatorname{SE}(n=4)$. 
Figure 8-2.

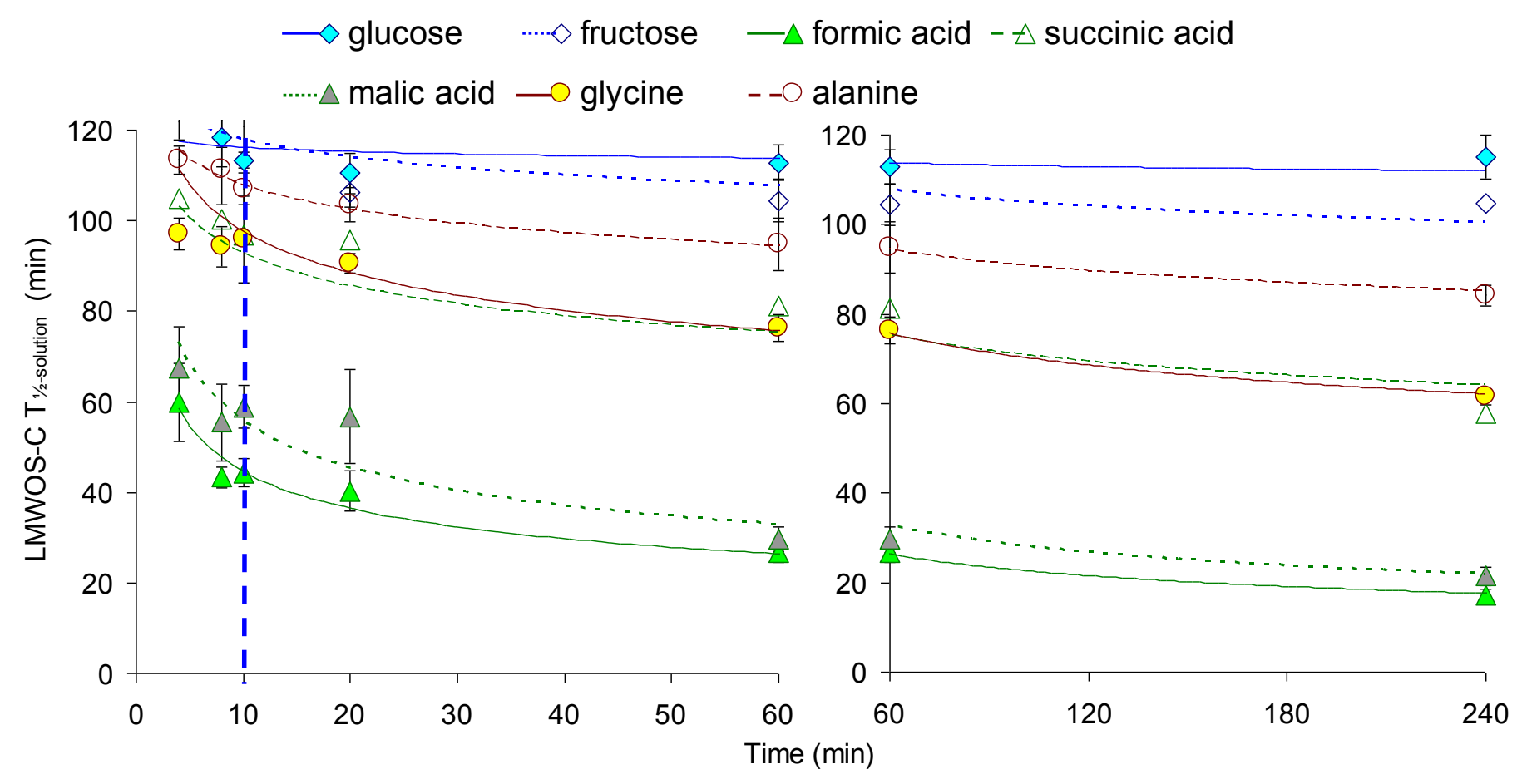

Supplementary figure 8-2. Temporal dynamics of ${ }^{14} \mathrm{C}$-labelled sugar, organic acid and amino acid disappearance from solution in an autoclaved soil. Values represent means $\pm \operatorname{SE}(n=4)$. Note, the different scales of $\mathrm{x}$-axis for the left and right parts of the figure. 


\section{Figure 8-3.}

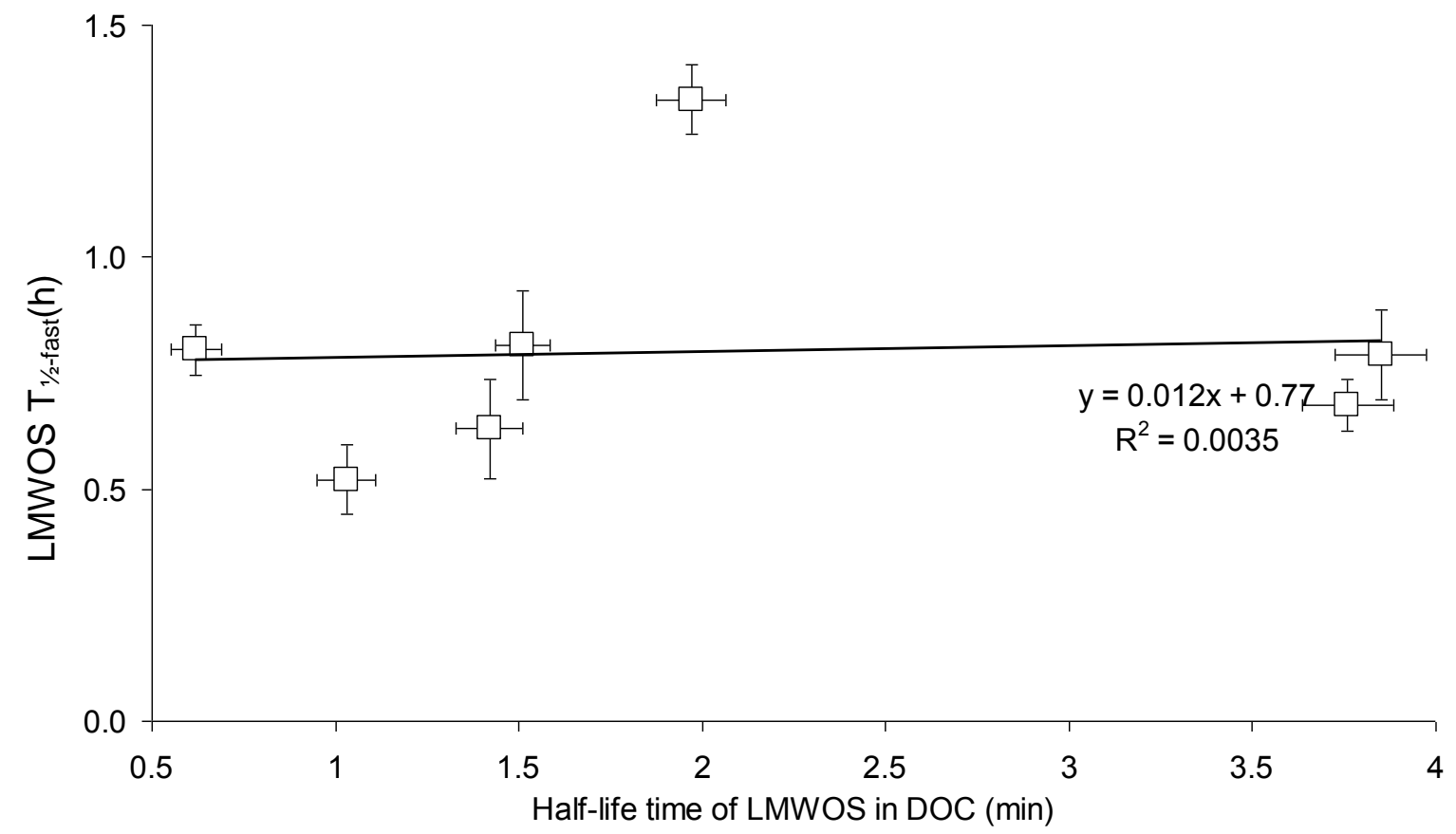

Supplementary figure 8-3. Relationship between the half-life (min) of different ${ }^{14} \mathrm{C}$-labelled LMWOS in soil solution (DOC) and the first rapid phase of ${ }^{14} \mathrm{CO}_{2}$ evolution $\left(\mathrm{C} T_{1 / 2-\text { fast }}\right.$ ). Values represent means $\pm \mathrm{SE}(n=4)$. 
Figure 8-4.
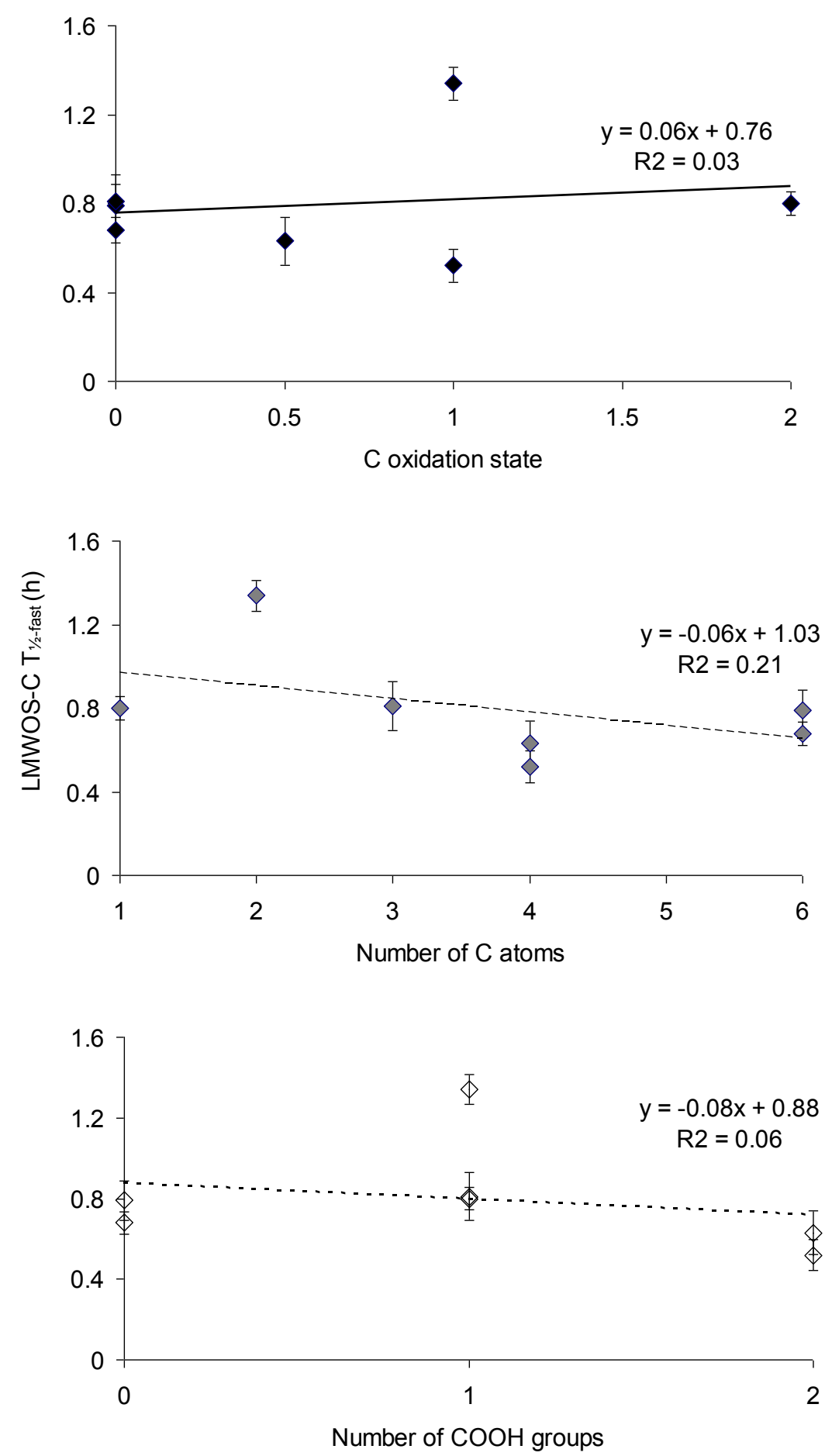

Supplementary figure 8-4. Relationship between the half-life of different LMWOS at the first rapid phase of ${ }^{14} \mathrm{CO}_{2}$ evolution $\left(\mathrm{C}_{T_{1 / 2} \text {-fast }}\right.$ ) (h) and the $\mathrm{C}$ oxidation state (top), number of $\mathrm{C}$ atoms in the LMWOS (middle) and number of $\mathrm{COOH}$ groups (bottom). Values represent means $\pm \mathrm{SE}(n=4)$. 
Figure 8-5.
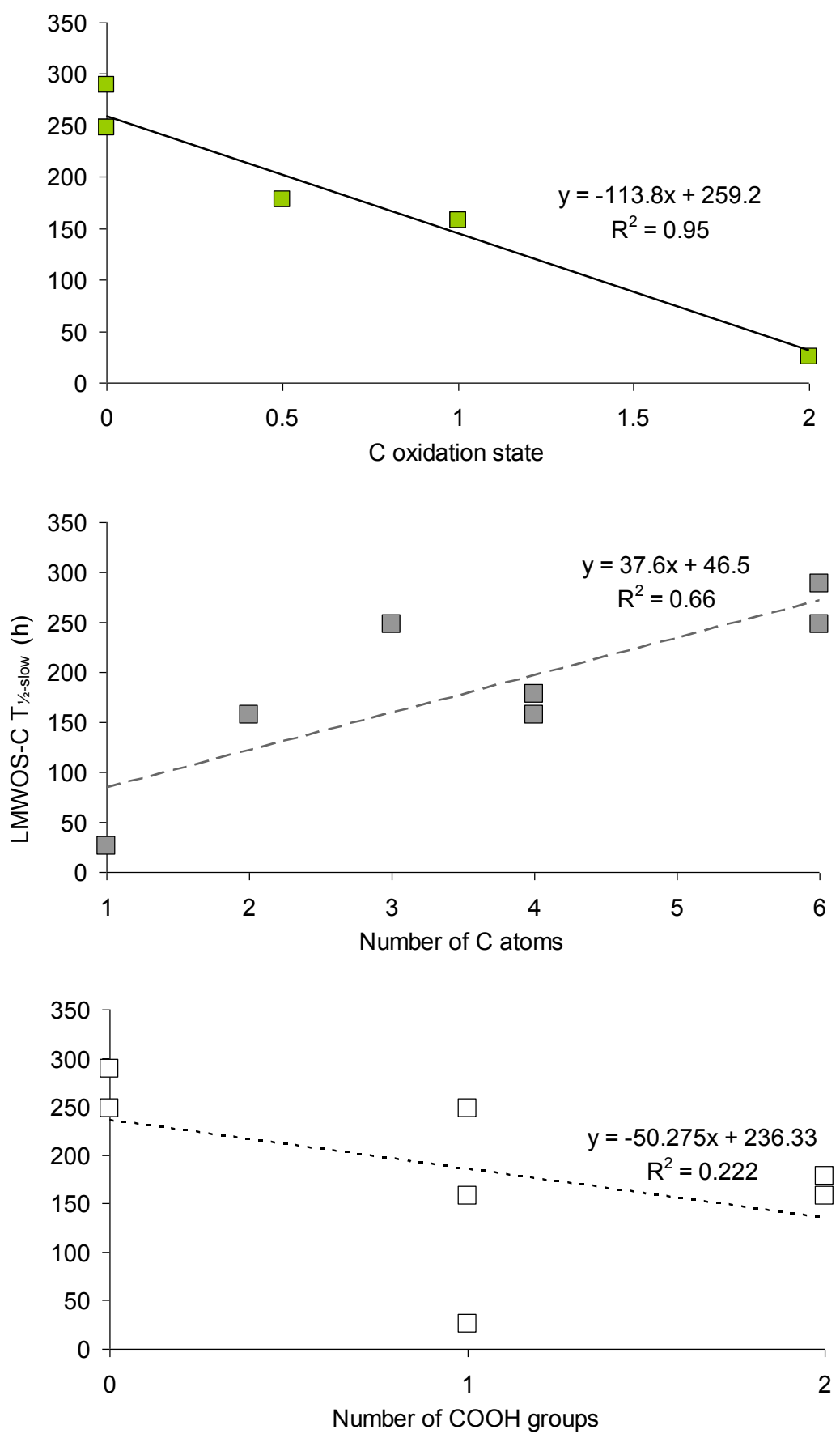

Supplementary figure 8-5. Relationship between the half-life of different LMWOS at the second slow phase of ${ }^{14} \mathrm{CO}_{2}$ evolution $\left(\mathrm{C}_{T_{1 / 2} \text {-slow }}\right)(\mathrm{h})$ and the $\mathrm{C}$ oxidation state (top), number of $\mathrm{C}$ atoms in the LMWOS (middle) and number of $\mathrm{COOH}$ groups (bottom). Values represent means $\pm \mathrm{SE}(n=$ 4). 


\section{Figure 8-6.}

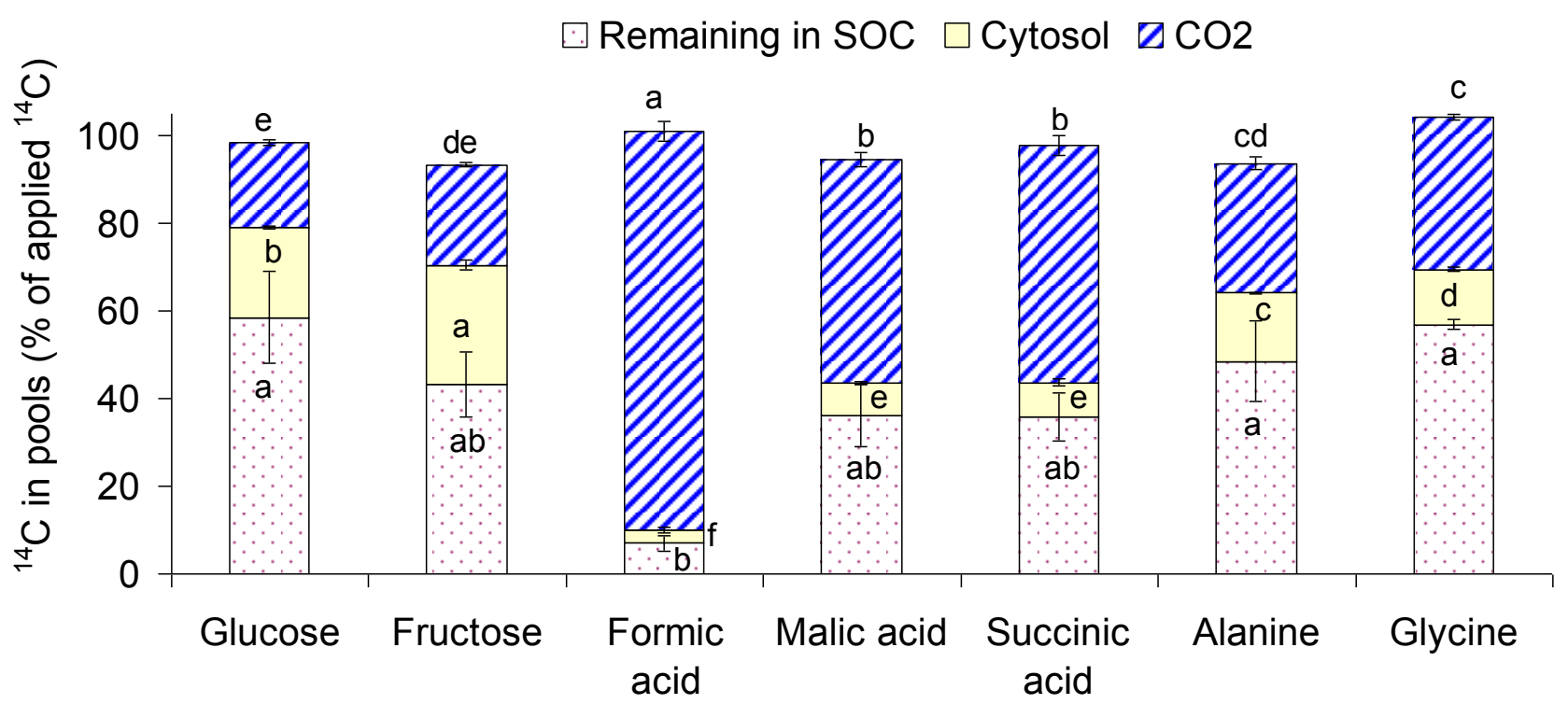

Supplementary figure 8-6. Partitioning of added ${ }^{14} \mathrm{C}$ from labelled substances (\% of total label added) between the $\mathrm{CO}_{2}$, cytosol and SOC pools. Columns present cumulative portions of ${ }^{14} \mathrm{C}$. Letters reflect significant differences $(\mathrm{p}<0.05)$ between the LMWOS and are presented separately for the $\mathrm{C}$ remaining in $\mathrm{SOC}$, incorporated into cytosol and $\mathrm{CO}_{2}$. Values represent means $\pm \mathrm{SE}(n=$ 4). 
Figure 8-7.
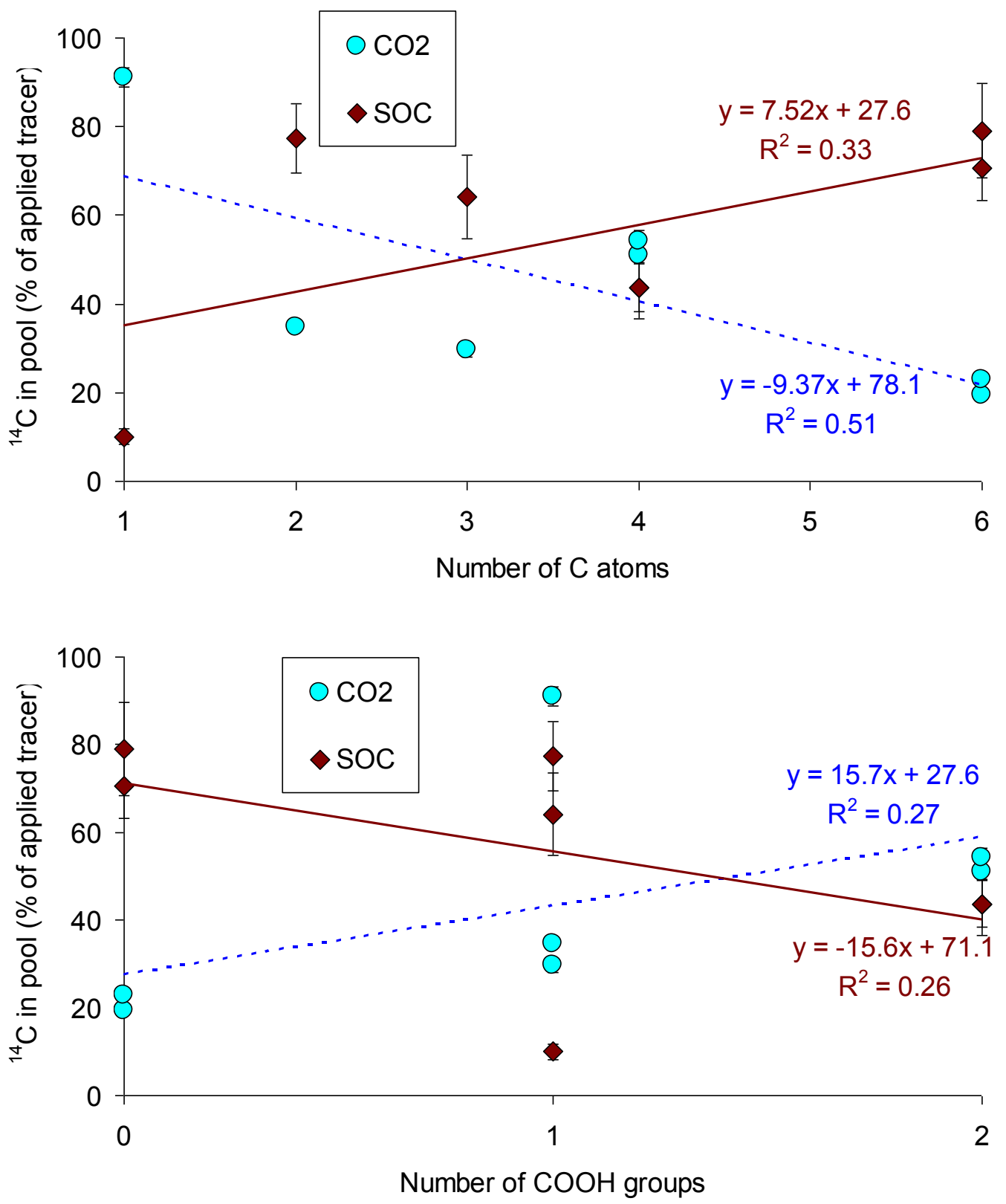

Supplementary figure 8-7. Relationship between ${ }^{14} \mathrm{C}$ remaining in the $\mathrm{SOC}$ and $\mathrm{CO}_{2}$ pools and number of $\mathrm{C}$ atoms (top panel) and number of - $\mathrm{COOH}$ groups (bottom panel) in different LMWOS. Values represent means $\pm \mathrm{SE}(n=4)$. 
Types of root systems of four tree species (Silver birch (Betula pendula, Roth), European alder (Alnus glutinosa L.), European beech (Fagus sylvatica, L.), and English oak (Quercus robur, L.) studied at the chapter 4 .

Silver birch

Type of rooting system for birch is heart-shaped, and usually strongly branched (Mauer and Palatova, 2003). The majority of roots is located at the depth of $40 \mathrm{~cm}$, and vertical roots are located till the depth of 80-100 cm (Starikov, 1969; Mayer, 1977). Horizontal roots can be 20-36 m in length (Mauer and Palatova, 2003). Fine roots occupy the uppermost humus layer and around 70\% of them are located within the first $60 \mathrm{~cm}$ of soil.
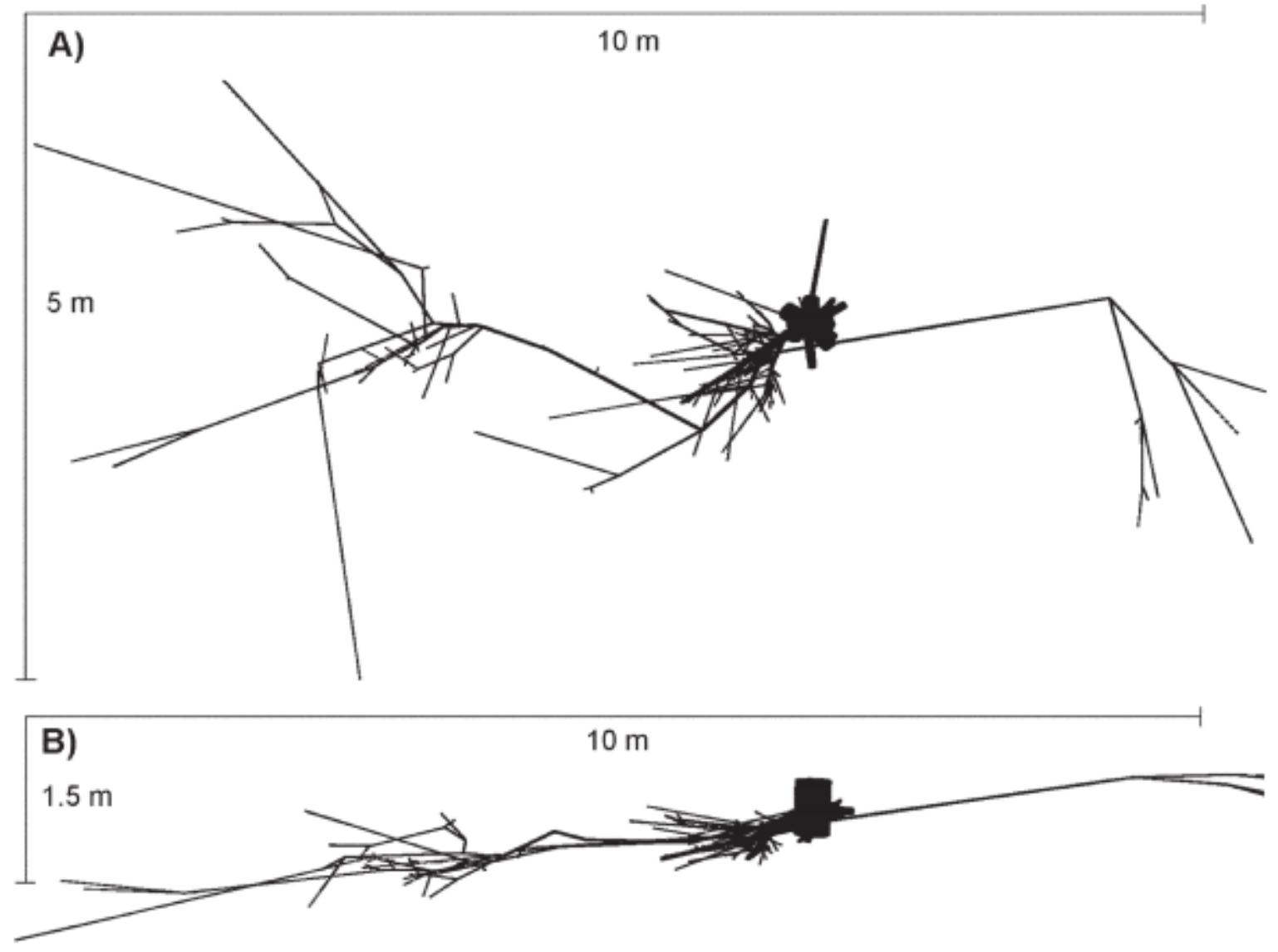

Supplementary figure A1. Type of root system of the 30-years old birch trees (Betula pendula), (Kalliokoski, Nygren and Sievänen, 2008). 


\section{Alder}

Alder has a deep, heart-shaped root system, which can be up to $5 \mathrm{~m}$ depth due to its adaptation to wet soil conditions, and most of the roots are located up the $2 \mathrm{~m}$ depth (Čermák and Fér, 2007). The elongation of root system is up $6 \mathrm{~m}$ around the stem. Amount of fine roots is lower, compared to birch (Mauer and Palatova, 2003).

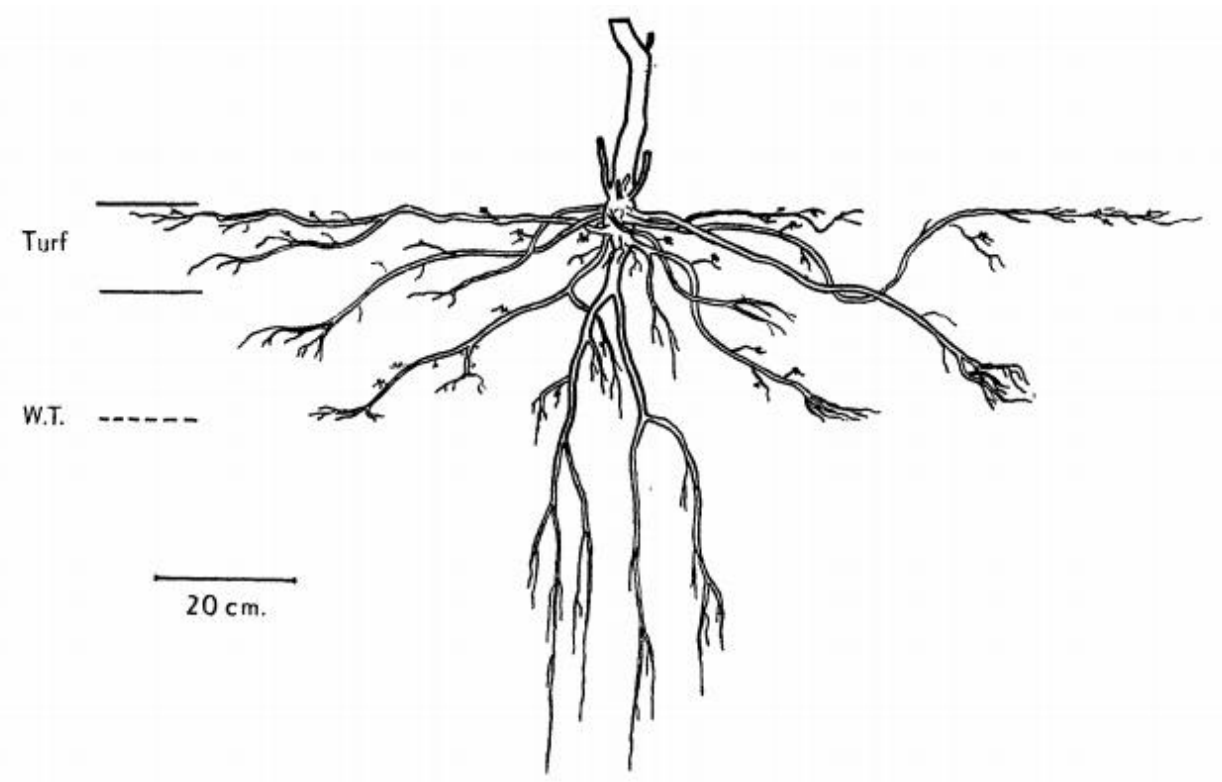

Supplementary figure A2. Root system of 3-years old alder, (McVean, 1956). 
Oak

The root system of oak trees consists of central and outer parts. The central roots can be found 2$3 \mathrm{~m}$ away from the stem, whereas outer roots can be found several meter away (Lyford, 1980). Amount of fine roots is lower compared to birch (Mauer and Palatova, 2003).
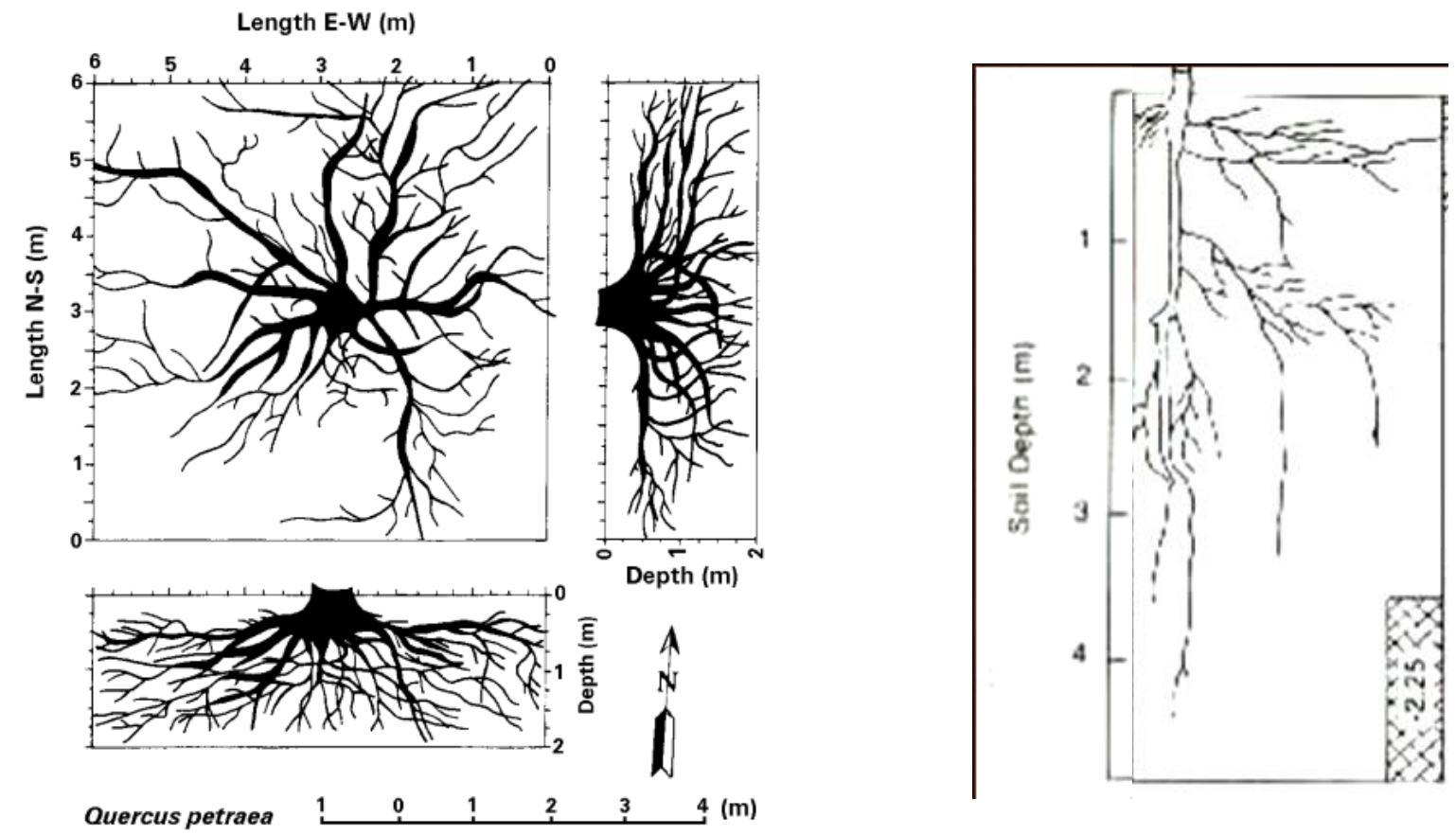

Supplementary figure A3. Root system of 50-years-old oak (Quercus petraea (Mattusch.), (Hruska et al., 1999) (left). Distribution of oak roots (Quercus alba), (http://www.deeproot.com/blog/blogentries/how-deep-do-tree-roots-grow) (right). 


\section{Beech}

The root system of beech depends on the groundwater level: in case of high water level, the tap root is not formed and the lateral roots have thin diameter; in case of low water level the massive tap root is formed and lateral roots are dense. The maximum volume of beech roots $(70 \%)$ is located at the depth of $1 \mathrm{~m}$ (Kodrik and Kodrik, 2002). Amount of fine roots is higher, compared to birch.

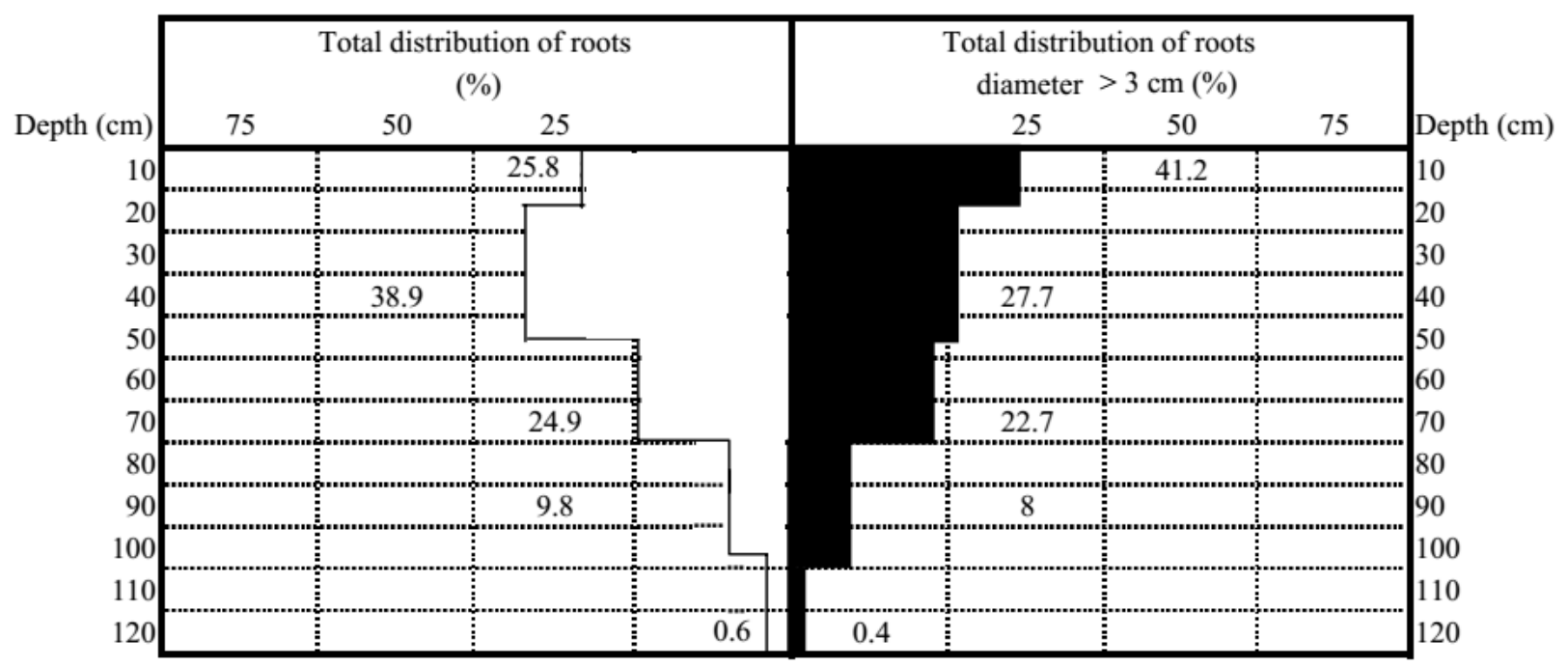

Supplementary figure A4. Distribution of total roots and roots with $>3 \mathrm{~cm}$ in diameter for the beech tree, (Kodrik and Kodrik, 2002).

\section{References (for "Types of root systems of four tree species...")}

Lyford W.H., 1980. Development of the root system of Northen red oak (Quercus Rubra, L.). Harvard forest paper, 21, 3-20.

Hruska J., Cermak J., Sustek S., 1999. Mapping tree root systems with ground-penetrating radar. Tree Physiology, 19, 125-130.

Mauer O., Palatova E., 2003. The role of root system in silver birch (Betula pendula, Roth) dieback in the air-polluted area of Krušnéhory Mts. Journal of forest science, 49(5), 191-199.

Kalliokoski T., Nygren P., Sievänen R., 2008. Coarse root architecture of three boreal tree species growing in mixed stands. Silva Fennica 42(2), 189-210.

Kordik J., Kordik M., 2002. Root biomass of beech as a factor influencing the wind tree stability Journal of forest science, 48(12), 549-564.

McVean D. N., 1956. Ecology of Alnus Glutinosa (L.) Gaertn: IV. Root System. Journal of Ecology, 44(1), 219-225.

Starikov J.A.,1969. Osobennosti rosta korněvych sistem někotorych drevesnych porod v pitomnikach. Les. Choz., 12, 28-30.

Čermák P., Fér F., 2007. Root systems of forest tree species and their soil-conservation functions on the Krušné hory Mts. slopes disturbed by mining. Journal of forest science, 53(12), 561-566.

http://www.deeproot.com/blog/blog-entries/how-deep-do-tree-roots-grow 


\section{Anna Gunina}

\section{Diplomas and Degrees}

2014-present Doctor of Philosophy /Doctor of natural sciences (both expected in September 2017), Bangor University, United Kingdom/ University of Göttingen, Germany

2004-2009 M.Sc. in Soil Science, Department of Soil Science, Lomonosov Moscow State University, Russia

\section{Professional Experience}

2012-2014 Researcher, Max Planck Institute for Biogeochemistry, Germany

$2012 \quad$ Early Stage Researcher, University of Bayreuth, Germany

2011-2012 DAAD research fellowship, University of Bayreuth, Germany

$2011 \quad$ Molter research fellowship, University of Bayreuth, Germany

2010-2011 Leader of the project of Russian federal targeted program «Scientific and scientific-pedagogical personnel» (2009-2013), Lomonosov Moscow State University, Russia

2009-2010 Early Stage Researcher, Lomonosov Moscow State University, Russia

Main Field of Work and Scientific Interests

Soil chemistry (stabilization of soil organic matter, low and high molecular weight organics, C isotopes)

Soil biology (microbial activity, contribution of microorganisms to soil organic matter formation, rhizosphere processes)

Molecular biomarkers (phospholipid fatty acids, amino sugars, sugars, lignin)

Biogeochemistry (carbon and nitrogen cycles in soil, flows of $C$ in plant-soil system)

\section{Technical skills}

Soil chemistry (SOC, SON, DOC analyses, chemical, particles and density fractionations of soil, basic soil properties determination, heavy metals extraction and analysis)

Soil microbiology (microbial activity measurement, extraction and analysis of phospholipid fatty acids, amino sugars, lignin, sugars, soil $\mathrm{CO}_{2}$ efflux analysis)

Application of isotopes $\left({ }^{13} \mathrm{C}\right.$ and ${ }^{14} \mathrm{C}$ plant and soil labeling under the field and lab conditions) Lab equipment (UV-VIS spectroscopy, fluorescence spectroscopy, $\beta$-spectroscopy, solid-phase extraction, isothermal calorimetry, HPLC, GC-MS, GC-IRMS)

Data analysis (Statistica 12.0, Microsoft Excel)

\section{Teaching experience}

2014 Co-supervision of Master work, Göttingen University, Germany

2014 Participating in the practical course "Application of biomarkers in soil science", Göttingen University, Germany

2017 Participating in the lecture course "Ecosystem Function \& Services", Bangor University, UK. Modules dedicated to introduction to soil science, soil properties, mineralogy and soil classification. 


\section{Awards and professional achievements}

2016-present Editorial board member: European Journal of Soil Biology; Forests

2014-present Occasional reviewer: Applied Soil Ecology, Geoderma, Biology and Fertility of Soils, Soil Biology and Biochemistry

2011-2012 DAAD fellow

$2011 \quad$ Molter fellow

\section{Advanced Courses}

2007-2017

Professional training:

Application of isotopes in soil science processes research, Göttingen

The Art of Scientific Writing, Copenhagen

Application of chromatographic analysis for the soil processes studies, Moscow

Application of molecular genetic approaches for the soil biodiversity studies, Moscow

Fluorescence visualization in biomedical and biotechnology researches, Moscow

Language courses:

English language for advanced speakers, Moscow

German language course in Freiburg, Bayreuth, Jena, Göttingen

\section{Participation in the Conferences}

2011-2017 European Geosciences Union General Assembly, Austria

2012 The $4^{\text {th }}$ International Congress EUROSOIL 2012, Italy

2009-2011 «Lomonosov» International conference, Russia 


\section{Declaration}

I hereby declare, to the best of my knowledge and belief, that this thesis contains no material previously published or written by another person, except where due reference has been made in the text of the thesis. This thesis contains no material which has been accepted or definitely rejected for the award of any other doctoral degree at any university.

\section{Erklärung}

Hiermit erkläre ich, die vorliegende Arbeit selbst verfasst, keine anderen als die angegebenen Quellen und Hilfsmittel benutzt sowie alle wörtlich und sinngemäß übernommenen Stellen in der Arbeit gekennzeichnet zu haben. Ferne erkläre ich, dass ich nicht anderweitig mit oder ohne Erfolg versucht habe, eine Dissertation einzureichen oder mich einer Doktorprüfung zu unterziehen. 


\title{
Response of soil microbial community to afforestation with pure and mixed species
}

\author{
Anna Gunina • Andrew R. Smith • \\ Douglas L. Godbold • Davey L. Jones • \\ Yakov Kuzyakov
}

Received: 14 July 2016 /Accepted: 26 September 2016

C) Springer Intemational Publishing Switzerland 2016

\begin{abstract}
Objectives Afforestation changes soil chemical properties over several decades. In contrast, microbial community structure can be shifted within the first decade and so, the direct effects of tree species can be revealed. The aim of this study was to determine the alteration of soil microbial community composition 10 years after afforestation by trees with contrasting functional traits.
\end{abstract}

\section{Responsible Editor: Zucong Cai.}

Electronic supplementary material The online version of this article (doi:10.1007/s11104-016-3073-0) contains supplementary material, which is available to authorized users.

A. Gunina - A. R. Smith - D. L. Jones

School of Environment, Natural Resources and Geography,

Bangor University, Bangor, Gwynedd LL57 2UW, UK

A. Gunina $(\bowtie) \cdot Y$. Kuzyakov

Department of Agricultural Soil Science, Georg August University of Gōttingen, Buesgenweg 2, 37077 Göttingen, Germany e-mail: guninaann@ gmail.com

D. L. Godbold

Institute for Forest Ecology, Universität für Bodenkultur, BOKU, Peter-Jordan-Straße 82, 1190 Vienna, Austria

Y. Kuzyakov

Department of Soil Science of Temperate Ecosystems, Georg August University of Gōttingen, 37077 Göttingen, Germany

Y. Kuzyakov

Institute of Environmental Sciences, Kazan Federal University, 420049 Kazan, Russia
Methods The study was conducted at the BangorDIVERSE temperate forest experiment. Soil samples were collected under single, two and three species mixtures of alder and birch, beech and oak early and secondary successional species, respectively, and contiguous agricultural field. Soil was analysed for total carbon $(\mathrm{C})$ and nitrogen $(\mathrm{N})$ contents, and microbial community structure (phospholipid fatty acids (PLFAs) analysis).

Results and conclusions The total PLFAs content (370$640 \mathrm{nmol} \mathrm{g}^{-1}$ soil) in forest plots increased for 30 to $110 \%$ compared to the agricultural soil $\left(290 \mathrm{nmol} \mathrm{g}^{-1}\right.$ soil). In contrast, soil $\mathrm{C}, \mathrm{N}$ and $\mathrm{C} / \mathrm{N}$ ratios were altered over 10 years much less - increased only up to $20 \%$ or even decreased (for beech forest).

Afforestation increased bacterial PLFAs by 20$120 \%$, whereas it had stronger impact on the development of fungal communities (increased by 50-200\%). These effects were proved for all forests, but were more pronounced under the monocultures compared to mixtures. This indicates that species identity has a stronger effect than species diversity. Principal component analysis of PLFAs revealed that under mono and three species mixtures similar microbial communities were formed. In contrast, gram-positive PLFAs and actinomycete PLFAs contributed mainly to differentiation of two species mixtures from other forests. Thus, at the early afforestation stage: i) soil biological properties are altered more than chemical, and ii) tree species identity affects more than species amount on both processes. 
Review paper

\section{Sugars in soil and sweets for microorganisms: Review of origin, content, composition and fate}

\section{Anna Gunina ${ }^{a, b}{ }^{*}$, Yakov Kuzyakov a, c}

¿Department of Agricultural Soll Science, Georg-August-Uhiversity of Cöttingen, Germany

b Department of Soil Bioingy and Bixctiemistry, Doluchoce Soll Science Institute, Russion Federntion

'Deportment of Sod Science of Temperate Ecosystems. Gearg-August-University of Gortingen. Germoro

\section{A R T I C L. E I N F O}

\section{Article histary:}

Received 21 April 2015

Received in revised form

24 July 2015

Available online 8 August 2015

\section{Kerword:}

Carbolydrates in soil

Glucose

Microbial utilizatio

Biochemical transformation

Low molecular weight organics
A B STRACT

Sugars are the most abundant oryanic compounds in the biosphere because they are monomers of al polysaccharides. We summarize the results of the last 40 years on the sources, content, composition and polysaccharides. We summarize the results of the last 40 years on the sources, content, composition and fate of sugars in soil and discuss their main functions. We especially focus on sugar uptake, utilization
and recycling by microorganisms as this is by far the dominating process of sugar transformation in soil compared to sorption, leaching or plant uptake. Moreover, sugars are the most important carbon (C) and energy source for soil microorganisms.

Two databases have been created. The 1st database focused on the contents of cellulose, non-cellulose, hot-water and cold-water extractable sugars in soils ( 348 data, 32 studies). This enabled determining the primary (plant-derived) and secondary (microbially and soil organic matter (SOM) derived) sources of carbohydrates in soil based on the galactose + mannose/arabinose $+x y l o s e(C M / A X)$ ratio. The $2 n d$

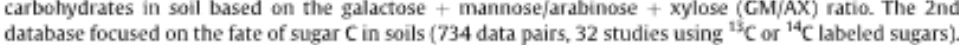
${ }^{13} \mathrm{C}$ and ${ }^{14} \mathrm{C}$ dynamics enabled calculating the: 1) initial rate of sugar mineralization, 2) mean residence time (MRT) of C of the applied sugars, and 3) MRT of sugar C incorporated into 3a) microbial biomass and 3b) SOM.

The content of hexoses was 3-4 times higher than pentoses, because hexoses originate from plants and microorganisms. The $\mathrm{GM} / \mathrm{AX}$ ratio of non-cellulose sugars revealed a lower contribution of hexoses in cropland and grassland (ratio 0.7-1) compare to forest (ratio 1.5) soils.

${ }^{13} \mathrm{C}$ and ${ }^{14} \mathrm{C}$ studies showed very high initial rate of glucose mineralization $\left(1.1 \mathrm{~min}^{-1}\right)$ and much higher rate of sugars uptake by microorganisms from the soil solution. Considering this rate along with the glucose input from plants and its content in soil solution, we estimate that only about $20 \%$ of al sugars in soil originate from the primary source - decomposition of plant litter and rhizodeposits. The remaining $80 \%$ originates from the secondary source - microorganisms and their residues. The estimated MRT of sugar $\mathrm{C}$ in microbial biomass was about 230 days, showing intense and efficient interna recycling within miceorganisms. The assessed MRT of sugar C in SOM was about 360 days, feflecting the considerable accumulation of sugar $\mathrm{C}$ in microbial residues and its comparatively slow

The very rapid uptake of sugars by microorganisms and intensive recycling clearly demonstrate the importance of sugars for microbes in soil. We speculate that the most important functions of sugars in soil are to maintain and stimulate microbial activities in the rhizosphere and detritusphere leading to mobilization of nutrients by accelerated SOM decomposition - priming effects. We conclude that the actual contribution of sugar $C$ (not only whole sugar molecules, which are usually determined) to SOM is much higher than the $10 \pm 5 \%$ commonly measured based on their content.

D 2015 Elsevier Ltd. All rights reserved.
- Corresponding suthor. Department of Agricultural Soil Science, Georg-AugustUniversity of Görtingen, Büsgermwę 2. 37077 Götingen. Germatry. Tel: +49 5513933505

E-madl address, guninaxnosymailcom (A. Gunina).

http://dx.doi.arg/10.1016/jsoilbio.2015.07.021

0038-0717, 2015 Elsevier Ld. All rizhts reserved.

\section{Introduction - why sugars?}

Sugars are the most abundant organic compounds in the biosphere because they are the basic components of all poly saccharides: cellulose, hemicellulose (polyoses), starch, pectin. 


\title{
Microbial uptake and utilization of low molecular weight organic substrates in soil depend on carbon oxidation state
}

\author{
Anna Gunina · Andrew R. Smith - Yakov Kuzyakov · Davey L. Jones
}

Received: 9 August 2016/Accepted: 23 February 2017/Published online: 6 March 2017

( Springer International Publishing Switzerland 2017

\begin{abstract}
The fate of low molecular weight organic substances (LMWOSs) in soil is regulated by microbial uptake. However, C oxidation state, the number of $\mathrm{C}$ atoms and $-\mathrm{COOH}$ groups in the LMWOS can affect their microbial utilization. Thus, the aim of this study was to reveal the effects of substance chemical properties on initial uptake and utilization of sugars, carboxylic and amino acids by microorganisms. Soil solution, spiked with ${ }^{14} \mathrm{C}$-labelled glucose, fructose, malate, succinate, formate, alanine or glycine, was added to the soil and ${ }^{14} \mathrm{C}$ was traced in the soil solution, $\mathrm{CO}_{2}$, cytosol, and soil organic carbon (SOC)
\end{abstract}

Responsible Editor: Edward Brzostek.

Electronic supplementary material The online version of this article (doi:10.1007/si0533-017-0313-1) contains supplementary material, which is available to authorized users.

A. Gunina - A. R. Smith - D. L. Jones

School of Environment, Natural Resources and

Geography, Bangor University, Bangor,

Gwynedd LL57 2UW, UK

A. Gunina (凶) - Y. Kuzyakov

Department of Agricultural Soil Science, Georg-August

University of Göttingen, Buesgenweg 2, 37077 Götingen,

Germany

c-mail: guninaann @ gmail.com

Y. Kuzyakov

Department of Soil Science of Temperate Ecosystems, Georg-August University of GB̈ttingen, 37077 Göttingen, Germany over $24 \mathrm{~h}$. The half-life time of all LMWOS in the soil solution varied between $0.6 \mathrm{~min}$ (formic acid) and $5.0 \mathrm{~min}$ (sugars), indicating its dependence on $\mathrm{C}$ oxidation state of the substances. The half-life time of ${ }^{14} \mathrm{C}$ in the fast mineralized pool in microorganisms, ranged between 30 (malic acid) and 80 (glycine) min and was independent on either $\mathrm{C}$ oxidation state, the number of $\mathrm{C}$ atoms, or number of $-\mathrm{COOH}$ groups. This suggests that intercellular metabolic pathways are more important for LMWOS transformation in soil than their basic chemical properties. The portion of mineralized LMWOS increased with their C oxidation state (20\% for sugars vs. $90 \%$ for formic acid) corresponding to the decrease of $\mathrm{C}$ incorporated into the cytosol and SOC pools. Concluding, the physicochemical properties of the common LMWOS allow predicting their microbial uptake from soil solution and subsequent partitioning of $\mathrm{C}$ within microbial biomass.

Keywords Carbon use efficiency - CUE .

Decomposition kinetics - Dissolved organic nitrogen . Organic acids

\section{Introduction}

Low molecular weight organic substances (LMWOSs) in soil originate from a wide range of sources, including root and microbial exudation, animal 